UNIVERSIDADE DE SÃO PAULO

ESCOLA DE COMUNICAÇÃO E ARTES

BEATRIZ SEQUEIRA DE CARVALHO

O processo de legitimação cultural das histórias em quadrinhos

São Paulo 


\section{O processo de legitimação cultural das histórias em quadrinhos}

\section{Versão Corrigida}

(versão original disponível na Biblioteca da ECA/USP)

Dissertação apresentada à Escola de Comunicação e Artes da Universidade de São Paulo para a obtenção do título de Mestre em Ciências da Comunicação.

Área de Concentração: Interfaces Sociais da Comunicação

Orientador: Prof. Dr. Waldomiro de Castro Santos Vergueiro

São Paulo 
Autorizo a reprodução e divulgação total ou parcial deste trabalho, por qualquer meio convencional ou eletrônico, para fins de estudo e pesquisa, desde que citada a fonte.

Carvalho, Beatriz Sequeira de

o processo de legitimação cultural das histórias em quadrinhos / Beatriz Sequeira de Carvalho. -- São Paulo: B. S. Carvalho, 2017.

175 p.: il.

Dissertação (Mestrado) - Programa de Pós-Graduação em Ciências da Comunicação - Escola de Comunicaçōes e Artes / Universidade de são Paulo.

Orientador: Waldomiro de Castro Santos Vergueiro Bibliografia

1. história em quadrinhos 2 . cultura 3. cultura de massa 4. legitimação cultural 5. campo I. Vergueiro, Waldomiro de Castro Santos II. Título. 
Nome: CARVALHO, Beatriz Sequeira de

Título: O processo de legitimação cultural das histórias em quadrinhos

Dissertação apresentada à Escola de Comunicação e Artes da Universidade de São Paulo para obtenção do título de Mestre em Ciências da Comunicação.

Aprovado em:

Banca Examinadora:

Prof. Dr.

Instituição:

Julgamento:

Assinatura:

Prof. Dr.

Instituição:

Julgamento:

Assinatura:

Prof. Dr.

Instituição:

Julgamento:

Assinatura: 
Para minha mãe, Fátima (in memorian).

Exemplo de mãe, de mulher, de profissional e, acima de tudo, de ser humano. 


\section{AGRADECIMENTOS}

À Escola de Comunicação e Artes da Universidade de São Paulo e ao Programa de PósGraduação em Ciências da Comunicação, não só pela oportunidade de desenvolvimento dada a tantos projetos importantes, mas pelo apoio ao universo da pesquisa, com um agradecimento especial a todo o corpo docente e discente, assim como a todos os funcionários da administração que tanto nos ajudam nesse processo.

À Coordenação de Aperfeiçoamento de Pessoal de Nível Superior (CAPES) pelo apoio financeiro para a realização desta pesquisa e que permitiu minha dedicação integral à mesma.

Ao meu orientador, Prof. Dr. Waldomiro de Castro Santos Vergueiro, não só por ter acreditado no potencial deste projeto, mas por todo o carinho, dedicação e orientação rigorosa em cada etapa da pesquisa, transformando todo esse processo em uma experiência inestimável. Com seu vasto conhecimento, mas sem nunca esquecer do bom humor, cada uma de nossas conversas ajudou no meu desenvolvimento não só profissional e acadêmico, mas também pessoal, com lições para toda a vida.

Ao meu pai, Carlos, por todo apoio e amor incondicional desde meu nascimento até agora. Acadêmico que é, ainda contribuiu com vários conselhos sobre esse universo, com conversas que abriram meu olhar para o mundo e me ajudaram a crescer.

Ao meus irmãos, Artur e Henrique, por serem os melhores companheiros e cúmplices que uma irmã mais nova poderia pedir. Vocês são os verdadeiros amores da minha vida.

À minha tia Deo, por ser a admiração em forma de mulher. Obrigada por todo o apoio, palavras de carinho e abraços nos momentos que mais precisei.

À Ester, por me mostrar, mesmo que não perceba, que é preciso buscar ser uma pessoa melhor todos os dias. Além de me ensinar a ter paciência. MUITA paciência.

À Camila, que transformou o conceito de "cunhada" em obsoleto. "Irmã" talvez defina melhor nossa relação.

Aos meus queridos avós, Zilka (in memorian), Efigênia (in memorian), Zoroastro e Jader (in memorian) por todo amor, cuidado e histórias, que transformaram cada um dos nossos momentos em memórias deliciosas.

À Dona Helena, Seu Hamilton (in memorian) e Heloísa, por abriem as portas de sua casa e me encherem de amor, me fazendo sentir parte dessa linda família.

Às minhas tias Marize e Vânia, não só pelas palavras encorajadoras ao longo dos anos, mas por terem se tornado verdadeiros exemplos para mim. 
À Yara e Uli, meus "pais postiços", e à Dona Vilma (in memorian), vulgo "Omi”, por me ensinar a forma correta de falar "Spiegelman".

À Adriana, Oscar e Eliana, por terem entrado na família e tornado tudo mais divertido.

À todos os meus tios e tias, primos e primas, meu mais profundo agradecimento. Seria impossível listá-los sem esgotar todo o espaço, mas tenham certeza do lugar especial que vocês têm na minha vida.

Aos professores doutores que ministraram as disciplinas que cursei na ECA, Mayra Rodrigues Gomes, Sandra Reimão, Maria Cristina Palma Mungioli, Celso Frederico e Alice Mitika, não só por todo o conhecimento que passaram, mas por me fazerem ter certeza que aqui era meu lugar.

Ao Prof. Dr. Ian Gordon, por acreditar em meu potencial, por todas as dicas e conselhos e pelas palavras de encorajamento nos último dois anos.

Aos membros da minha banca de qualificação, professores doutores Nobuyoshi Chinen e Iuri Andreas Reblin, pela inestimável contribuição que deram a este estudo que, sem dúvida nenhuma, deu os direcionamentos necessários para a conclusão dessa pesquisa.

Aos meus orientadores na PUC-SP, professores doutores Silvia Borelli e Edmilson Felipe, responsáveis por me apresentar e me guiar no universo da pesquisa durante minha graduação, além de todo o carinho e dedicação.

Às professoras doutoras Ana Laura Gamboggi e Soledad Galhardo, do Centro Universitário SENAC, que com suas aulas durante minha especialização reabriram as portas do mundo acadêmico para mim.

Aos companheiros do Observatório de Histórias em Quadrinhos, por me receberam tão bem e por me fazerem sentir em casa a cada reunião. A cada encontro vocês comprovam que esse é o melhor lugar para se estar.

Um agradecimento mais do que especial àqueles que são meu suporte, meu alicerce, minha rocha, meus queridos amigos Beatriz Tolezano, Lenora Bruhn, Isabelle Pignot, Bruno Gaspari, Gabriela Tremonte, Jaca Almeida, Daniela Marino, Maria Sant'anna, Natália Marreti, Roberta Campi, Gabriela Favarini, Mariana Almeida, Gean Gonçalves, Camilla Carandino, Guilherme Gurgel, Pricila Graziano e Luiza Dequech. Tenham certeza que sem o amor e o suporte de vocês eu não teria chegado até aqui.

À todas e todos os entusiastas da Nona Arte, responsáveis por transformar esse "processo de legitimação" em uma realidade. Ademais, um agradecimento especial aos pesquisadores brasileiros que vieram antes de mim, e aos que compartilham desse universo comigo hoje. Se não fosse por vocês, o campo dos quadrinhos não teria se tornado tão rico e incrivelmente vasto e essa pesquisa não seria possível. Muito obrigada! 
Quando você não entende uma pintura, você acha que é burro. Quando não entende uma história em quadrinhos, acha que o cartunista é burro. 


\section{RESUMO}

CARVALHO, Beatriz Sequeira de. O processo de legitimação cultural das histórias em quadrinhos. 2017. 175f. Dissertação (Mestrado) - Escola de Comunicação e Artes, Universidade de São Paulo, São Paulo, 2017.

O presente trabalho objetiva buscar um maior entendimento da história em quadrinhos como produto cultural e compreender como, com o passar dos anos, ela passou por um processo de legitimação que a tirou do estigma de mero artigo de massa, sem nenhum valor cultural, para um objeto culturalmente valorizado. Buscou-se em um primeiro momento compreender de onde surge o preconceito contra a cultura de massas e, consequentemente, contra as histórias em quadrinhos, e como tal preconceito pode ser entendido a partir de uma relação de poder estabelecida pelo uso do conceito de "cultura". Para tal, a abordagem metodológica inicial baseou-se nos Estudo Culturais, especialmente a partir da reformulação do conceito de cultura proposto por Raymond Williams, além das premissas de outros estudiosos da cultura, focando principalmente nos conceitos de ideologia, de John B. Thompson, e de distinção, de Pierre Bourdieu. Dentro de uma abordagem fenomenológica, foi selecionada a Hermenêutica da Profundidade proposta por John B. Thompson. A técnica de coleta de dados utilizada é a documentação indireta, formada pela pesquisa bibliográfica (os textos, acadêmicos ou não, afins com o objeto e metodologia adotados) e a pesquisa documental (o conjunto das histórias em quadrinhos selecionado). Traçou-se, a partir daí, uma linha do tempo no contexto norte-americano que buscou demonstrar que o processo de legitimação cultural teve início na década de 1960 com o movimento intelectual europeu e o movimento underground norte-americano, seguidos pela publicação de Maus, de Art Spiegelman, e da chegada das graphic novels ao mercado. Ademais, buscou-se elucidar como as histórias em quadrinhos constituem-se como um campo de produção cultural específico e autônomo, que pouco tem a ver com o campo da literatura ou das artes plásticas. Para tal, voltamo-nos ao conceito de campo de Pierre Bourdieu. Como resultados principais, foi identificado que os quadrinhos passaram a ser valorizados como um produto cultural legítimo e instâncias que antes os desprezavam, passaram a reconhecer seu valor e importância no espectro cultural mundial. Com esses resultados, visa-se contribuir para a cristalização do entendimento da história em quadrinhos como um campo de produção cultural legítimo, fazendo com que o debate sobre o mesmo cresça e se diversifique cada vez mais.

Palavras-chave: história em quadrinhos; cultura; cultura de massa; legitimação cultural; campo 


\begin{abstract}
CARVALHO, Beatriz Sequeira de. The cultural legitimation process of comics. 2017. 175f. Dissertação (Mestrado) - Escola de Comunicação e Artes, Universidade de São Paulo, São Paulo, 2017.

This study aims to seek a greater understanding of comics as a cultural product and to understand how, over the years, it has undergone a process of legitimation that has removed it from the stigma of mere mass article, with no cultural value, for a culturally valued object. We sought at first to understand where prejudice against mass culture and consequently against comics arises, and how such prejudice can be understood from a relation of power established by the use of the concept of "culture ". For this, the initial methodological approach was based on the Cultural Studies, especially from the reformulation of the concept of culture proposed by Raymond Williams, in addition to the premises of other culture scholars, focusing mainly on the concepts of ideology, by John B. Thompson, and of distinction, by Pierre Bourdieu. Within a phenomenological approach, the Depth Hermeneutics proposed by John B. Thompson was selected. The technique of data collection used is indirect documentation, constituted by bibliographic research (texts, academic or not, related to the object and methodology adopted) and documentary research (the set of selected comics). A time line was drawn, in the North American context, which sought to demonstrate that the process of cultural legitimacy began in the 1960s with the European intellectual movement and the North American underground movement, followed by the publication of Art Spiegelman's Maus and the arrival of graphic novels in the market. In addition, we tried to elucidate how comics constitute a specific and autonomous field of cultural production that has little to do with the field of literature or the plastic arts. To this end, we turned to Pierre Bourdieu's field concept. As main results, it was identified that the comic books came to be valued as a legitimate cultural product and instances that previously despised them, began to recognize its value and importance in the world cultural spectrum. With these results, it aims to contribute to the crystallization of the understanding of comics as a legitimate cultural production field, making the debate about it grow and diversify more and more.
\end{abstract}

Keywords: comics; culture; mass culture; cultural legitimization; field 


\section{LISTA DE FIGURAS}

Figura 1 - A análise quadro a quadro de Steve Canyon feita por Umberto Eco também modificou os parâmetros das pesquisas em quadrinhos. 80

Figura 2 - Trabalho de S. Clay Wilson para a Zap Comix............................................84

Figura 3 - Extrato de The Fabulous Furry Freak Brothers, de Gilbert Shelton.........86

Figura $4-M r$. Natural, um dos grandes personagens do underground.........................88

Figura 5 - Capa original de Breakdowns, autobiografia de Spiegelman........................95

Figura 6 - Trabalho de Spiegelman na capa da revista The East Village Other, considerada um dos primeiros semanários underground e que ajudou a definir o que

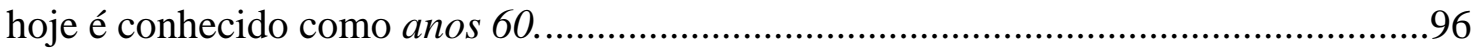

Figura 7 - Extrato de Binky Brown Meets the Holy Virgin Mary, de Justin Green.....98

Figura 8 - Capa da edição \#7 da Arcade, que trouxe trabalhos de Robert Crumb, Harvey Kurtzman, Spain Rodriguez, S. Clay Wilson, entre outros quadrinistas do

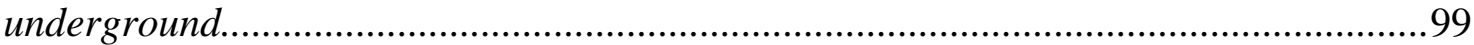

Figura 9 - A primeira versão de Maus, de 1972, publicada na revista Raw.................100

Figura 10 - A primeira cena de Maus e nosso primeiro contato com Vladek...............102

Figura 11 - Um pequeno exemplo do por que o tema, o estilo, a técnica e a coragem fizeram de Maus uma obra sem precedentes............................................................105

Figura 12 - Capa de Um contrato com Deus e outras histórias de cortiço, de Will Eisner. 111

Figuras 13 e 14 - Capas das duas edições de Maus, lançadas separadamente e depois compiladas

Figura 15 - Capa do capítulo II de Watchmen. Publicada originalmente em doze edições mensais, foi posteriormente compilada e classificada como graphic novel. .113

Figura 16 e 17 - Habib, de Craig Thompson e Asterios Polip, de David Mazzucchelli: obras mais longas que já chegaram às mãos do público finalizadas 114

Figura 18 - Extrato do segundo volume de Terapia, disponibilizado na internet. O primeiro volume ganhou versão impressa pela editora Novo Século.

Figura 19 e 20 - Epiléptico, de David B. e Black Hole, de Charles Burns, histórias que se privilegiaram e que talvez não fossem possíveis sem o novo suporte. .128

Figura 21 - Como a imagem e o texto funcionam em Alice no país das maravilhas. 156 


\section{SUMÁRIO}

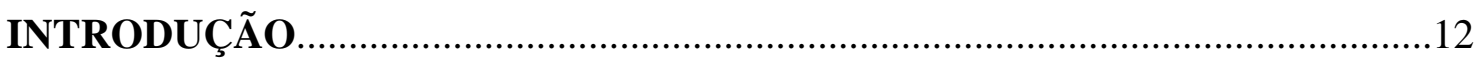

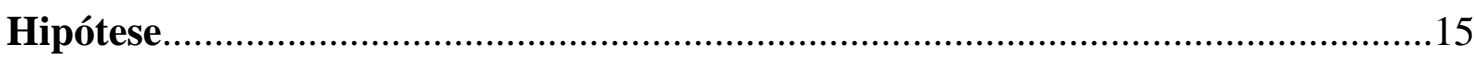

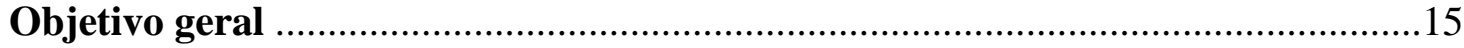

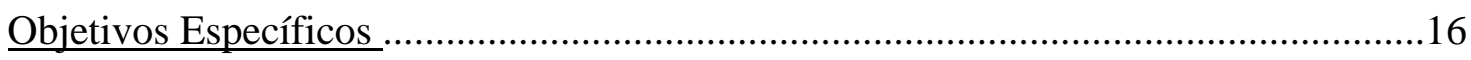

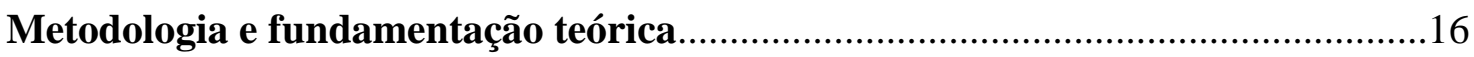

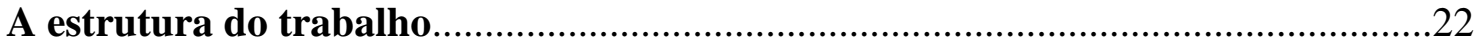

1 A METACRÍTICA DA CULTURA DE MASSA: CULTURA, IDEOLOGIA E

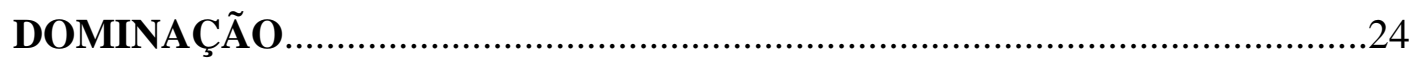

1.10 conceito de "cultura": uma problemática de poder.....................................25

1.2 A origem da crítica à cultura de massa: os "apocalípticos" ..............................37

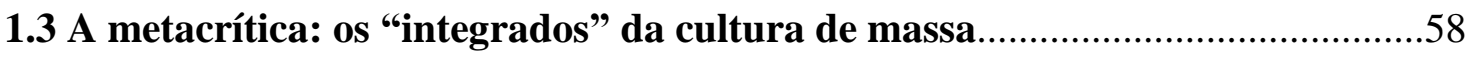

1.4 Como os quadrinhos se posicionam nessa configuração.................................66

2 DO UNDERGROUND AO PULTZER: O INÍCIO DO PROCESSO DE VALORIZAÇÃO CULTURAL DAS HISTÓRIAS EM QUADRINHOS.......76

2.1 A década de 1960: como ela modificou o que se entendia por "quadrinhos"..78

2.2 O papel de Maus na revitalização do meio.......................................................92

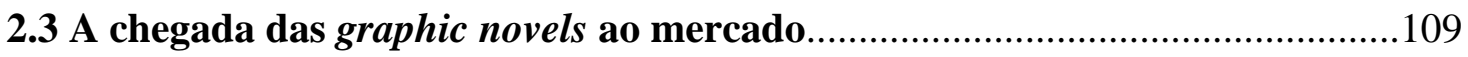

3 RECONHECENDO O CAMPO DOS QUADRINHOS: A CONSOLIDAÇÃO DO PROCESSO DE LEGITIMAÇÃO CULTURAL ....................................133

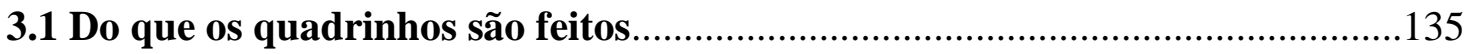

3.2 O campo dos quadrinhos: ele existe e é legítimo............................................143

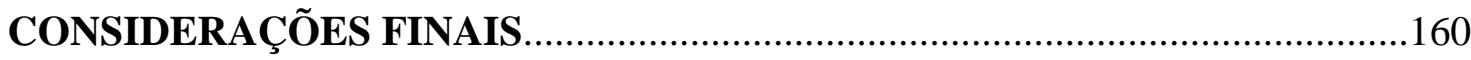

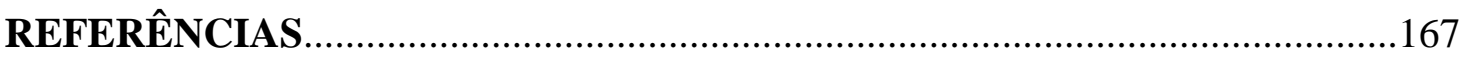




\section{INTRODUÇÃO}

A pesquisadora britânica Mel Gibson (2012) conta em British Girls' Comics, Readers and Memories como seu interesse no estudo de quadrinhos, voltado para a pesquisa de audiência, teve início. Segundo ela, três incidentes que aconteceram em diferentes períodos de sua vida influenciaram sua escolha de entender como a leitura dos quadrinhos era e é percebida na cultura britânica. Contar a história desses três incidentes, afirma Gibson, possibilita ilustrar como as questões que gostaríamos de pesquisar podem surgir de experiências pessoais ou profissionais.

O primeiro incidente aconteceu quando a autora tinha apenas 5 anos de idade e sua professora pediu para que os alunos levassem à aula seu material de leitura favorito. Sem pestanejar, ela levou uma história do Batman. Ao mostrar o que havia escolhido à professora, a mesma ordenou que Gibson voltasse para casa e retornasse à classe apenas com um material de leitura que fosse apropriado. Isso fez com que ela desenvolvesse uma vontade ainda maior de ler quadrinhos, levando-a a procurar entender porque eles eram considerados inadequados e impróprios. "Uma pergunta inicial que pode levar à pesquisa poderia ser, simplesmente, por que os quadrinhos aborreciam tanto aquela professora?" (GIBSON, 2012, p.267).

A partir do que aconteceu, Gibson (2012) buscou compreender como, no Reino Unido, os quadrinhos eram diretamente relacionados a uma noção de cultura popular como insignificante em comparação com a alta cultura, como a pintura e a ópera, por exemplo. As visões expressas por sua professora, ela diz, podem estar ligadas a uma série de questões, incluindo censura, classe, o medo dos quadrinhos diminuírem as habilidades literárias e a corrupção da juventude, e o que também pode ser descrito como "pânicos morais” (GIBSON, 2012, p. 267). E é exatamente isso que buscarei abordar nesta pesquisa. Isso, porque este primeiro incidente descrito por Gibson mostrase bastante semelhante a minha experiência pessoal - mesmo que ela tenha ocorrido já na graduação em Ciências Sociais, quando comecei a entrar no universo dos quadrinhos - e o que me levou a escolher os quadrinhos como objeto de pesquisa.

Sou, digamos, uma leitora recente de quadrinhos. Apesar de desde pequena ter contato com as histórias em quadrinhos, meus interesses se estendiam à Turma da Mônica, Mafalda e uma ou outra revista da Disney que minha mãe trazia para casa quando ia comprar suas palavras-cruzadas. E era só. Meu entendimento do que eram as 
histórias em quadrinhos se resumia a isso. Ainda que meus pais jamais tenham proibido a leitura delas, nem mesmo quando eu e meus dois irmãos saímos da infância, tampouco nenhum de nós três tomou os quadrinhos como um hobby. Isso, entretanto, não impediu que Artur, Henrique e eu nos interessássemos pelos outros produtos derivados das grandes histórias de super-heróis. Éramos, os três, loucos pelo desenho dos X-Men da década de 1990 e eu, particularmente, apaixonada pelos dois filmes do Batman de Tim Burton (1989; 1992), por mais que o Pinguim do Denny DeVitto me desse - e ainda dê - calafrios e que ainda considero como os melhores filmes baseados no HomemMorcego - mesmo que praticamente todo mundo que conheço prefira a Trilogia o Cavaleiro das Trevas dirigida por Christopher Nolan (2005; 2008; 2012). Fazer o quê?

E assim eu segui durante toda minha infância e adolescência. Continuei lendo Turma da Mônica e Mafalda, é claro, mas os livros policiais de Agatha Christie e a saga do gênero fantasia protagonizada pelo jovem Harry Potter eram minhas verdadeiras paixões, enquanto o tão vasto universo dos quadrinhos permanecia muito distante. Por isso, não faltaram momentos em que eu mesma questionei: “o que estou fazendo aqui, tendo as histórias em quadrinhos como objeto de pesquisa, se nem quadrinhos eu lia na infância?”. Bom, essa é uma ótima pergunta. E ela teria uma resposta bem diferente se a história terminasse por aqui. Mas ela não termina.

Aos 18 anos, enquanto fazia cursinho para prestar o vestibular de jornalismo, algo mágico aconteceu: conheci as Ciências Sociais. Quando fui apresentada a esse mundo, ele parecia tão mais rico, tão mais vasto que qualquer outro que eu me apaixonei perdidamente. Mesmo ninguém da família entendendo o curso, nem sequer tendo ouvido falar dele, eu prestei o vestibular para Ciências Sociais e não me arrependi. Mas não mesmo. Sou daquelas que quando perguntam "mas qual a sua formação?", levanto a cabeça, bato no peito com muito orgulho e digo: "sou cientista social". E foi durante a graduação que os quadrinhos ressurgiram na minha vida. E, dessa vez, de maneira avassaladora.

Logo no primeiro semestre da graduação em Ciências Sociais na PUC-SP, a antropologia foi a cadeira que de cara me fascinou. Por conta disso, já no segundo ano eu resolvi fazer uma iniciação científica na área e foi assim que conheci minha orientadora, Prof. Dra. Silvia Borelli, que me apresentou e me guiou pelo mundo da pesquisa acadêmica durante grande parte da minha graduação. No grupo de pesquisa 
coordenado por ela, do qual fiz parte, o foco era a etnografia. Intitulado Jovens Urbanos: ações estético-culturais e novas práticas políticas, a proposta era a de fazer uma análise das novas práticas políticas juvenis do Brasil que estivessem desvinculadas da política tradicional, focando em manifestações estético-culturais que se constituem como lugares de ações políticas. Apesar de ter feito parte do grupo e aprendido muito durante dois anos e meio, na hora de escolher o tema da monografia me vi presa em um dilema. E não porquê eu não gostava do que fazia na iniciação científica, mas porquê no terceiro ano, um pouco antes dos alunos escolherem o tema dos seus trabalhos finais, li uma obra que acabaria mudando para sempre - sem exageros - a minha vida: Maus.

A história de Art Spiegelman (2005) modificou tão profundamente minha percepção das coisas que acabei desistindo de fazer minha monografia seguindo o tema da minha iniciação científica, que já trabalhava há dois anos, para escrever sobre Maus e mergulhar de vez no universo dos quadrinhos. E, enquanto desenvolvia o projeto, começaram a acontecer os "incidentes" de que fala Mel Gibson: algumas pessoas passaram a, de certa forma, condenar o meu objeto de pesquisa. Enquanto alguns colegas não entendiam o porquê da minha escolha por estudar uma mídia considerada de "massa" e "alienante", um professor afirmou que meu tema não deveria passar pelo departamento de antropologia, pois história em quadrinhos é literatura e não ciências sociais.

Por isso, assim como aconteceu com Mel Gibson, esses incidentes aumentaram ainda mais minha vontade de estudar as histórias em quadrinhos para entender, afinal, o porquê do choque das pessoas quando aquelas se tornam um objeto de pesquisa. Para mim, não fazia sentido dizer que uma obra como Maus, ou qualquer outra que passei a ler desde então, podia ser considerada menos interessante ou relevante do que qualquer outro objeto escolhido por meus colegas. Além disso, como alguém podia dizer que quadrinhos são literatura se, para mim, uma coisa não tinha nada a ver com a outra? Foi então que minha monografia, concluída em 2011 e intitulada A “Art” de Spiegelman: as histórias em quadrinhos como gênero literário e a estética mausiana (CARVALHO, 2011), que focaria apenas em Maus e em Art Spiegelman, ganhou um pequeno capítulo que buscava entender o que se tinha contra os quadrinhos e a cultura de massa. E foi a partir desse pequeno capítulo, e de toda a discussão que ele gerou na minha cabeça, que eu cheguei até aqui. 


\section{Hipótese}

Por conta desses meus "incidentes" durante a graduação, entender as histórias em quadrinhos no contexto da cultura de massas e o preconceito gerado ao redor delas tornou-se minha meta. Entretanto, com o passar do tempo percebi que, apesar de ainda haver resquícios desse tipo de julgamento em relação ao meio, as coisas pareciam estar mudando. Ao me aprofundar cada vez mais nesse universo, percebi que os quadrinhos estavam recebendo mais atenção positiva da crítica e agregando cada vez mais leitores, leitores esses diferentes dos já fãs dos quadrinhos de super-herói das grandes editoras. Então, o que havia mudado? O porquê de todas aquelas teorias e textos que havia lido execrando os quadrinhos, além daquele punhado de pessoas que haviam criticado meu objeto de estudo, estarem perdendo força enquanto uma nova visão sobre os quadrinhos passou a ser construída nos últimos anos? Por que obras quadrinísticas agora são altamente elogiadas e um novo mercado, cada vez mais diverso e rico, cresce a cada dia?

Levando-se em consideração o que foi anteriormente mencionado, minha hipótese baseia-se na ideia de que se antes as histórias em quadrinhos eram consideradas como um "subproduto" da cultura, nas últimas décadas elas teriam passado por um processo de legitimação cultural. Entender, então, as origens dessa nova percepção em relação aos quadrinhos tornou-se, de uma maneira geral, o objetivo da presente pesquisa, conforme definido a seguir.

\section{Objetivo Geral}

Buscar um maior entendimento da história em quadrinhos como produto cultural e compreender como, com o passar dos anos, ela passou por um processo de legitimação que a tirou do estigma de mero artigo de massa, sem nenhum valor cultural, para um objeto culturalmente valorizado. Por isso, na tentativa de entender esse processo, foram delineados alguns objetivos específicos que visaram ajudar nessa compreensão. 
Objetivos específicos

1) Compreender de onde surge o preconceito contra a cultura de massas e, consequentemente, contra as histórias em quadrinhos, e como tal preconceito pode ser entendido a partir de uma relação de poder estabelecida pelo uso do conceito de "cultura".

2) Mostrar como dois movimentos da década de 1960, o movimento intelectual europeu e o movimento underground norte-americano, modificaram o entendimento do que eram as histórias em quadrinhos, tornando-se, assim, o marco inicial do processo de legitimação cultural do campo, seguidos pela publicação de Maus, de Art Spiegelman, e da entrada das chamadas graphic novels no mercado.

3) Elucidar como as histórias em quadrinhos constituem-se como um campo de produção cultural específico e autônomo, que pouco tem a ver com o campo da literatura ou das artes plásticas.

\section{Metodologia e fundamentação teórica}

Levando-se em consideração a trajetória que me trouxe até aqui, e de acordo com o tema, objetivos e hipótese explicitados, a abordagem inicial proposta neste estudo privilegiará os Estudos Culturais. Isso, porque os Estudos Culturais, desde sua origem, incluem as formas nas quais os rituais da vida cotidiana, suas instituições e práticas, a cultura popular e os meios de comunicação de massa ao lado das Artes, como constitutivos de uma formação cultural, transgredindo assim um passado que entendia a cultura apenas como artefatos. Ao ampliar o significado do que é "cultura", os Estudos Culturais permitiram que toda produção de sentido pudesse ser considerada objeto de estudo (MATTELART, NEVEU, 2004).

Dentro da Universidade de Birmingham, na cidade de Birmingham, na Inglaterra, o Centre for Contemporary Cultural Studies (CCCS), que deu origem aos 
chamados Estudos Culturais, nasceu em 1964 com o intuito de renovar os instrumentos de análise crítica tradicionais. Para isso, utilizou os métodos e os instrumentos da crítica textual e literária e deslocou sua aplicação dessas obras clássicas e "legítimas" para os produtos da cultura de massa e para o universo das práticas culturais populares (MATTELART, NEVEU, 2004). A área dos Estudos Culturais não constituiu necessariamente uma nova disciplina, mas é resultado de uma insatisfação com algumas disciplinas e seus limites. Constitui-se, assim, como um campo de estudos em que diversas disciplinas interagem para estudar os aspectos culturais da sociedade contemporânea (ESCOSTEGUY, 1998).

Desse modo, a partir do momento em que os Estudos Culturais passam a focar nas formas de expressão cultural não-tradicionais, a legitimidade cultural é transposta. Como consequência, a cultura popular e os meios de comunicação de massa passam eles mesmos a alcançar a legitimidade, tornando-se lugar de análise crítica de práticas que antes eram entendidas fora da esfera da cultura. Esta legitimidade, acreditamos, é um processo pelo qual as histórias em quadrinhos também vêm passando. E é por isso que os Estudos Culturais constituem nosso posicionamento epistemológico, pois construíram, desde o início, uma propensão fundamental de crítica cultural que questiona a fixação de hierarquias entre formas e práticas culturais (MATTELART, NEVEU, 2004), estas instituídas a partir de oposições como "alta" e "baixa" cultura, entre cultura "superior" e "inferior", e outra vertentes opostas entre si.

O procedimento de abordagem que irá orientar a pesquisa, dentro do escopo da abordagem epistemológica, é o enfoque fenomenológico. Este enfoque permitirá reconstruir o objeto pesquisado - no caso, as histórias em quadrinhos - em busca de sua compreensão. Dentro da modalidade da fenomenologia, a abordagem metodológica será a Hermenêutica, esta especializada na interpretação das narrativas e das formas simbólicas. Mais especificamente, utilizaremos a Hermenêutica da Profundidade proposta por John B. Thompson (1995) em Ideologia e Cultura Moderna.

A Hermenêutica da Profundidade de Thompson parte da compreensão imediata que se tem de uma forma simbólica, analisa objetivamente essa interpretação preliminar e reinterpreta seu significado (GOMES, 2015). A Hermenêutica da Profundidade, para Thompson (1995), estabelece-se como um referencial geral para a análise cultural e que pode, além disso, ser adaptado para a análise da ideologia. Como se pretende, na 
primeira parte deste estudo, fazer uma análise cultural a partir das noções de ideologia e dominação, este se constitui em um bom caminho a ser seguido.

Seguindo a proposta de Thompson (1995), esta forma de análise especificada é empregada com o objetivo de realçar o caráter ideológico das formas simbólicas, ou seja, o objetivo seria o de evidenciar as maneiras como o sentido funciona para estabelecer e sustentar relações de dominação. Interpretar a ideologia, portanto, significa especificar a relação entre o sentido que é mobilizado pelas formas simbólicas e as relações de dominação que esse sentido sustenta, desmascarando o sentido que está a serviço do poder. Entretanto, enquanto Thompson (1995) procura analisar o caráter ideológico das formas simbólicas que são mediadas pelos meios de comunicação de massa, na presente análise outro caminho será proposto: o de entender o caráter ideológico da dita "alta cultura", esta entendida como uma forma simbólica, e sua relação de dominação com a cultura de massa e, mais especificamente, com as histórias em quadrinhos, e como essa relação se sustenta a partir da distinção e ideologia impostas por um grupo dominante sobre a massa que ascende socialmente, o que impediria a consideração dos quadrinhos como um produto cultural legítimo.

Ademais, dentro da chamada "abordagem tríplice" proposta por Thompson (1995) este estudo privilegiará o emissor como objeto, ou seja, o foco será a análise sócio-histórica da produção e transmissão da história em quadrinhos dentro do contexto da cultura de massa em oposição à alta cultura, de maneira a tentar entender como se dá o processo de valorização cultural pelo qual os quadrinhos têm passado. Esta análise sócio-histórica proposta por Thompson (1995), que visa reconstruir as condições sociais e históricas de produção, será utilizada a partir dos seguintes métodos conjugados: a história geral do objeto, sua história editorial e técnica e seus momentos dramáticos, sempre pensados no contexto da "alta" versus "baixa" cultura. Somente após realizar esta análise da condição sócio-histórica dos quadrinhos, dentro deste contexto específico, foi possível escolher os momentos-chave e as obras que melhor contribuem para análise de procedimento.

Neste sentido, a técnica de coleta de dados utilizada nesta pesquisa é a documentação indireta, formada pela pesquisa bibliográfica (os textos, acadêmicos ou não, afins com o objeto e metodologia adotados) e a pesquisa documental (o conjunto das histórias em quadrinhos selecionadas) (GOMES, 2015). Portanto, para a realização 
da pesquisa proposta, o enfoque foi o trabalho teórico a partir da leitura, síntese e análise das bibliografias referentes aos temas e conceitos propostos. Ademais, para a análise dos momentos-chave e histórias em quadrinhos selecionadas, a técnica utilizada foi o entendimento da relevância social e histórica destes para o processo de legitimação cultural dos quadrinhos. Em outras palavras, esta análise buscou compreender qual a importância no contexto em que foram criadas e como modificaram as percepções acerca das histórias em quadrinhos. Nossa seleção privilegiou os momentos e autores mais significativos a partir da década de 1960, entendida, na presente análise, como a chave para se compreender a valorização cultural das histórias em quadrinhos.

Seguindo as premissas acima elencadas, a fundamentação teórica também tem como ponto de partida os Estudos Culturais. Dado que, assim como colocado anteriormente, os integrantes do CCCS se preocuparam, logo de partida, com os produtos das culturas popular e de massa, que representavam e expressavam os caminhos da cultura contemporânea (ESCOSTEGUY, 1998, p. 89). O ponto de partida do campo, portanto, é a atenção sobre as estruturas sociais e o contexto histórico como fatores básicos para o entendimento da ação dos meios massivos, assim como o desvio do eixo da cultura em sua tradição elitista para as práticas cotidianas. Por conta disso, assim como os objetos que estuda, o Centro foi, desde seu início, marcado pela marginalidade institucional, ao não se encaixar na ortodoxia das pesquisas acadêmicas tradicionais. Por isso, a escolha desse campo de estudos como base referencial teórica desta pesquisa não poderia ser mais preciso.

O Centro surge inspirado na pesquisa As Utilizações da Cultura, de Richard Hoggart (1973a; 1973b), que faz o foco voltar-se sobre os anteriormente menosprezados materiais culturais da cultura popular, por meio de uma metodologia qualitativa. Este trabalho de Hoggart inaugura a visão de que, no espaço popular, não existe apenas submissão, como sempre se pensou, mas também resistência. O CCCS nasce, dessa forma, de uma recusa do legitimismo, das hierarquias acadêmicas e dos objetos considerados nobres. "Eles se fixam sobre a aparente banalidade da publicidade, dos programas de entretenimento, das modas vestimentares" (MATTELART, NEVEU, 2004, p. 72) e, ao fazerem isso, deslocam o foco da figura dos dirigentes para o da sociabilidade cotidiana dos grupos que fazem parte do universo do popular. 
Destarte, se num primeiro momento pretende-se compreender a razão pela qual as histórias em quadrinhos sofreram com o desprezo cultural, é preciso pensar essa questão a partir de uma problemática de poder, que opõe a "alta" cultura de um grupo dominante à "baixa" cultura da massa que começa a ascender socialmente. E por isso os Estudos Culturais se mostraram de vital importância no desenvolvimento deste estudo. Isso, porque como coloca Douglas Kellner (2001), as lutas focalizadas pelos estudos culturais críticos são contra a dominação e subordinação. Contudo, sua maior preocupação não é a de desenvolver a análise de qualquer luta ou resistência, e sim da luta contra a dominação e contra as estrutura desiguais e opressoras que são destacadas por esses estudos.

Tais estudos, dessa forma, situam a cultura em um contexto sócio-histórico no qual esta pode promover tanto dominação quando resistência, assim como criticam as formas culturais que promovem a subordinação. O ponto de maior relevância para nós é ressaltar que os estudos culturais subvertem a distinção entre cultura superior e inferior e acabam valorizando formas culturais antes vistas como "inferiores", como o cinema, a televisão e também as histórias em quadrinhos, que foram deixadas de lado por grande parte das teorias que os antecederam. Segundo Kellner (2001), os integrantes da escola de Birmingham foram os responsáveis por rejeitar o termo "cultura de massa", considerando que este termo tende a ser elitista ao criar uma oposição entre "alto" e "baixo". O conceito "cultura de massa", portanto, despreza essa "massa" e sua cultura.

Raymond Williams é o teórico dos Estudos Culturais que melhor tratou a ideia de que uma cultura dita "superior" rejeita a cultura de massa graças a uma visão elitista que despreza a massa em si. Isso, porque Williams (1979; 1992; 2003; 2011) compreendeu que, ainda no século XVIII, a cultura passou a significar algo em si mesma, um valor que se possui ou, mais especificamente, um valor que apenas alguns têm ou que podem aspirar a ter. Quando se espiritualiza, portanto, automaticamente se exclui, pois essa "verdadeira cultura" se confunde com a educação a que apenas alguns têm acesso: os homens superiores. Raymond Williams, deste modo, junta-se ao movimento de desconstrução dessa ideia de cultura, levando a cabo assim a reconstrução do conceito.

Essa reformulação da compreensão do conceito de cultura a partir de sua crítica, proposta por Raymond Williams, demonstra como a cultura se configura como um 
campo de batalha que diferencia e separa os grupos em dominantes/dominados e superiores/inferiores. Com isso, produzem-se hierarquias e classificações que estão de acordo com os propósitos das elites dominantes. Dessa maneira, para entender melhor como se produzem essas separações e hierarquias, iremos além dos Estudos Culturais e partiremos para as premissas de outros estudiosos da cultura, focando mais intensamente nos conceitos de "ideologia" de John B. Thompson (1995) e de “distinção” de Pierre Bourdieu (2007).

O conceito de "ideologia" de Thompson (2015) ajudará a entender como o sentido em uma forma simbólica, no caso a "alta" cultura, serve para estabelecer e sustentar relações de dominação, ao passo que o conceito de "distinção" de Bourdieu (2007) nos traz à visão que os gostos funcionam como definidores de classe, o que leva à distinção de uma "nobreza cultural" por meio da diferenciação desses gostos e ideias sobre a cultura, transformando a definição dominante como a forma correta de apropriação cultural. Ambos os conceitos, aliados à reavaliação do conceito de cultura de Williams, ajudaram a entender a origem dos preconceitos contra as histórias em quadrinhos ao questionar e revisar a compreensão difundida do que é cultura, estimulando uma reflexão crítica sobre as relações de poder e dominação presentes na oposição entre a cultura da elite e a cultura de massa, colocando em evidência as posições daqueles que mais se beneficiam e dos que menos se beneficiam das relações sociais existentes.

É só a partir de todas essas premissas que, acredito, seja possível entender como as histórias em quadrinhos passaram por um processo de legitimação cultural. Se antes elas sofriam com o desprestígio, que pode ser melhor compreendido por meio dos questionamentos levantados a partir da contextualização dos conceitos dos autores apresentados, parece agora que elas dissolveram as barreiras entre "alta" e "baixa" cultura e passaram a figurar no hall dos grandes objetos culturais. Isso, porque os dois movimentos que se estabelecem na década de 1960, somados à publicação e reconhecimento de Maus e à invasão das graphic novels no mercado permitiu que os quadrinhos deixassem de lado o estigma que por décadas carregaram de ser apenas um entretenimento barato e sem nenhum valor cultural. Entretanto, esse processo de legitimação cultural ainda não chegou ao fim. A solidificação desse processo só se dará quando a noção de que história em quadrinhos constitui um campo de produção cultural específico, que pouco tem a ver com o da literatura ou das artes plásticas, como 
comumente se disseminou, de fato venha a se estabelecer. Para tal, tomarei emprestado mais um conceito do pensador francês Pierre Boudieu (1992): o conceito de "campo".

\section{A estrutura do trabalho}

A partir desta introdução, em que conto um pouco da minha trajetória, além da explicitação da minha hipótese, objetivo, metodologia e fundamentação teórica, foram delineados três capítulos, além das considerações finais:

- No primeiro capítulo, intitulado A metacrítica da cultura de massa: cultura, ideologia e dominação, farei a revisão da noção de "cultura de massa" a partir de uma ideia de metacrítica, a fim de compreender a origem do preconceito contra a cultura de massa. Esse preconceito se estabelece quando a noção de "cultura" é utilizada pelas classes dominantes como uma forma de subjugar, a partir de uma lógica de poder, a nova classe que ascende socialmente ao desconsiderar como cultura legítima tudo aquilo que foge aos preceitos e regras da elite. As histórias em quadrinhos, nascidas dentro da cultura de massa, acabam também sofrendo com esse desprestígio. Por isso, antes de entender como se dá o processo de legitimação cultural dos quadrinhos, é preciso entender porquê eles não eram considerados legítimos e, para tal, busquei situar os quadrinhos nessa configuração.

- O segundo capítulo tratará dos momentos e obras-chave que permitiram a abertura para a aceitação dos quadrinhos como um produto culturalmente valorizado. Em Do underground ao pulitzer: o início da valorização cultural dos quadrinhos, o movimento intelectual europeu e o movimento underground norte-americano são considerados os que, ao modificarem o entendimento do que são as histórias em quadrinhos, deram o pontapé inicial para o processo de legitimação cultural do meio, seguidos posteriormente pela publicação e aclamação de Maus, de Art Spiegelman, e pelo aumento na produção e nas vendas das graphic novels. 
- Reconhecendo o campo dos quadrinhos: a consolidação do processo de legitimação cultural, terceiro e último capítulo, busca demonstrar que as histórias em quadrinhos configuram-se como um campo de produção cultural próprio, e não parte de outros campos de produção, como a literatura ou as artes plásticas e que, a partir desse entendimento, os quadrinhos se estabeleceriam por completo como um objeto cultural legítimo.

- Nas considerações finais, as noções fundamentais delineadas durante toda a pesquisa serão resgatadas e discutidas, especialmente a ideia de que houve um processo de legitimação que vem reconhecendo os quadrinhos como produto cultural de grande valor, e as consequências desse processo.

- Nas referências constarão as obras utilizadas ao longo da dissertação. 


\section{A METACRÍTICA DA CULTURA DE MASSA: CULTURA, IDEOLOGIA E DOMINAÇÃO}

Edgar Morin (1986), define a palavra "cultura", no segundo volume do livro Cultura de Massas no Século XX, da seguinte forma:

Cultura: falsa evidência, palavra que parece uma, estável, firme, e no entanto é a palavra armadilha, vazia, sonífera, minada, dúbia, traiçoeira. Palavra mito que tem a pretensão de conter em si completa salvação: verdade, sabedoria, bem-viver, liberdade, criatividade... (MORIN, 1986, p.75).

A palavra "cultura" talvez seja uma dessas palavras na qual o seu verdadeiro significado permaneça uma incógnita. Se puxarmos pela memória, lembraremos de vários momentos em que as conversas com os amigos, ou mesmo na sala de aula, levantaram a questão: “Mas, afinal, o que é cultura?”. E a resposta a essa pergunta sempre parece sem solução. Entretanto, sempre que essa pergunta surge, ela está ligada a algum questionamento referente ao que pode ou não ser considerado como "cultura de verdade", ou seja, aquilo que é digno de ser considerado ou não como um objeto cultural. Muitos são os exemplos: enquanto a música clássica, o filme cult do grande diretor europeu e a literatura são considerados como "cultura de verdade", o funk, a franquia de filmes blockbuster e - por muito tempo - as histórias em quadrinhos, são considerados como inferiores, como não dignos de serem chamados pelo nome de "cultura".

No caso das histórias em quadrinhos, objeto da presente pesquisa, suas raízes e forma de difusão popular explicariam a rejeição ao meio como um objeto culturalmente valorizado. Como um meio de comunicação, uma de suas origens remonta às empresas jornalísticas norte-americanas, no final do século XIX que, a fim de aumentar a circulação de seus jornais, iniciam a publicação deste tipo de conteúdo. Desde o começo, sua principal característica foi a de comunicação de massa: com a necessidade de atingir um grande público, exigiu dos produtores melhores e mais modernos processos de impressão gráfica (LUYTEN, 1987). É nesse contexto de criação, ou seja, inseridas como produto das empresas jornalísticas norte-americanas, e posteriormente vendidas em bancas em formato de revista - funcionando assim como uma forma 
alternativa e mais barata de entretenimento -, que se atribui à história em quadrinhos sua característica de comunicação de massa.

Por isso, apesar dos inúmeros desenhistas que levaram à frente um pensamento mais amplo, criando histórias que retratam, por meio do humor e da crítica social, cada época, cada momento da vida do ser humano da maneira mais direta possível, marcando, definitivamente, os acontecimentos do século XX (LUYTEN, 1987), os quadrinhos sofreram muito no que diz respeito ao desprestígio por parte de intelectuais e educadores. A condição de "subproduto da cultura" que segue os quadrinhos se dá exatamente por sua estrutura industrial de grande escala, que envolve interesses econômicos que poderiam, segundo críticos, comprometer seu relacionamento mais dinâmico com a cultura.

Mesmo quando levamos em consideração que os quadrinhos "ultrapassaram a condição de instrumento de consumo para tornarem-se símbolo da civilização contemporânea" (LUYTEN, 1987, p. 09) e, por isso, cada um de seus elementos design, desenho, cartum e a criação escrita - merecerem consideração isoladamente, as histórias em quadrinhos foram, durante anos, ignoradas como forma digna de discussão (EISNER, 2010), pois foram transformadas no bode expiatório perfeito dos críticos da chamada "cultura de massa", relegando os quadrinhos a uma condição de "baixa cultura", opondo-se assim aos grandes objetos culturais da chamada "alta cultura" que deveriam, segundo seus defensores, determinar os gostos e comportamentos dos homens.

Nesse contexto, nosso questionamento não será mais aquele discutido na roda de amigos ou na sala de aula que tentava entender "mas, afinal, o que é cultura?"; agora, para tentar explicar o porquê dos quadrinhos terem sido por tantas décadas considerados como um subproduto da cultura, nosso foco será o de tentar responder à seguinte pergunta: "mas, afinal, quem definiu o que é e o que não é cultura?".

\subsection{O conceito de "cultura": uma problemática de poder}

O conceito de cultura, etimologicamente falando, deriva do conceito de natureza. Segundo Terry Eagleton (2011), esta palavra, considerada a mais nobre das atividades 
humanas, também tem sua origem no trabalho e na agricultura, colheita e cultivo. Para Eagleton (2011), a palavra "cultura" representa uma dessas raras ideias que são essenciais tanto para a esquerda política quanto para a direita, o que faz com que sua história social seja extraordinariamente confusa e ambivalente. Assim, indo no sentido oposto ao da maioria, afirma Eagleton que a definição de cultura é menos uma questão de desconstruir a oposição entre cultura e natureza e mais uma questão de se reconhecer que o termo "cultura" é, por si só, uma desconstrução. Entretanto, ainda segundo Eagleton (2011), há outro sentido no qual a palavra cultura está voltada para duas direções opostas, sugerindo uma divisão entre nós mesmos: entre aquela parte de nós que se cultiva e refina, e aquilo que dentro de nós constitui a matéria-prima para esse refinamento (EAGLETON, 2011, p. 15).

Em Palabras Clave (2003), Raymond Williams distingue três sentidos modernos da palavra. Tendo como base suas raízes etimológicas no trabalho rural, a palavra vai, primeiramente, significar "civilidade"; no século XVIII, torna-se sinônimo de "civilização" no sentido de progresso intelectual, espiritual e material - como sinônimo de "civilização", a cultura pertencia ao espírito geral do iluminismo, com o seu culto ao desenvolvimento secular, progressivo e racional; a partir do século XIX, deixa de ser sinônimo de civilização e passa a ser seu antônimo.

Como sinônimo de "cultura", a palavra "civilização" é em parte descritiva, pois pode designar neutramente uma forma de vida (como a civilização Asteca, por exemplo), e em parte normativa, cuja designação remonta a uma forma de vida por seu esclarecimento e refinamento (o que o adjetivo "civilizado" faz, hoje em dia, de uma maneira mais óbvia). Em outras palavras, cultura como civilização significa a vida como a conhecemos, mas também indica que ela é superior ao barbarismo (EAGLETON, 2011, p. 20). A palavra, desse modo, implica um juízo de valor: algo que não é apenas correto, mas muito melhor do aquilo que o precedeu. O termo, segundo Eagleton (2011), remete a uma classe média europeia pré-industrial, de boas maneiras, refinamento e elegância.

Contudo, no século XIX, "civilização" passa a adquirir uma conotação imperialista, o que desacreditou a palavra aos olhos de alguns liberais. Consequentemente, era necessária outra palavra para dizer como a vida social deveria ser ao invés de como era. Assim, os alemães, tomando emprestado o termo culture dos 
franceses, fizeram da palavra "cultura" o nome da crítica romântica pré-marxista. Enquanto "civilização" remete aos bons modos e maneiras cordiais, cultura passou a ser algo mais solene, crítico e de altos princípios, ao invés de estar em total acordo e harmonia com o mundo. Em suma, a emergência pela palavra "cultura" é o fato de que "civilização" começou,cada vez mais, a soar menos plausível como um termo valorativo (EAGLETON, 2011, p. 22).

Contudo, o conceito de cultura nos termos modernos, segundo Raymond Williams (2011), surgiu à época da Revolução Industrial. A partir dos textos de grandes escritores e pensadores da língua inglesa do século XIX, no livro Cultura e Sociedade, publicado originalmente em 1958, o pensador inglês situa a história do conceito de cultura e como ele se desenvolveu para o entendimento que temos dele hoje.

Segundo Williams (2011), entre o final do século XVIII e até a metade do século XIX, palavras que hoje são importantes na língua inglesa surgiram pela primeira vez e, mesmo aquelas que já haviam sido utilizadas anteriormente, ganharam novos significados também importantes. Tais palavras estão ligadas entre si, na medida em que há um padrão geral de mudança em todas elas, e este padrão fornece um caminho que torna possível analisar mudanças mais amplas na vida e no pensamento. Estas palavras, segundo Williams (2011), são: indústria, democracia, classe, arte e cultura. As mudanças ocorridas com essas palavras em língua inglesa, naquele período, são indicativos de uma mudança geral também nas instituições sociais, políticas e econômicas, os objetivos dessas instituições, as relações com elas e os objetivos de nossas próprias atividades.

Entre todas as palavras mencionadas, ressalta Williams (2011), o desenvolvimento da palavra "cultura" é o mais surpreendente. Isso, porque as questões ligadas aos significados da palavra "cultura" são diretamente relacionadas com as grandes mudanças históricas advindas das transformações que a indústria, a democracia e a classe representam, assim como intimamente ligadas com as mudanças na arte. $\mathrm{O}$ desenvolvimento da palavra cultura é representativo de um registro das reações importantes e permanentes causadas por essas tantas mudanças em nossa vida social, econômica e política.

Antes desse período crítico e cheio de mudanças, “cultura” significava apenas, como também descrito por Eagleton (2011) "tendência ao crescimento natural" e 
depois, por analogia, um processo de treinamento humano. Esse último uso, de cultura de "algo", passou por uma transformação no século XIX e caiu em desuso, dando espaço para uma cultura "como tal", uma coisa em si mesma. Nesse sentido, são quatro as características desse novo significado: 1) "um estado geral ou hábito da mente" ligado com a ideia de perfeição humana; 2) "uma situação de desenvolvimento intelectual em uma sociedade comum a todos"; 3) "o corpo geral de artes"; 4) "todo um modo de vida, material, intelectual e espiritual" - ou seja, "cultura" em seu sentido antropológico (WILLIAMS, 2011, p. 18).

Uma das fontes primárias da ideia de cultura encontra-se, dessa forma, nos escritos de Wordsworth (WILLIAMS, 2011). Baseando-se na teoria social de Burke, Wordsworth entendia a cultura como o "espírito personificado de um povo", como uma espécie de padrão de excelência, em que o conhecimento do povo é algo superior ao verdadeiro curso dos eventos e do funcionamento do mercado. No decorrer do século esse padrão de excelência passou a ser disponível, como uma espécie de tribunal de recursos em que os reais valores eram definidos a partir de sua oposição com o que considerava padrões artificiais.

Estes padrões artificiais eram aqueles nascidos do mercado, o que levou à sujeição das artes aos seus princípios e passou a ser vista como uma forma especializada de produção sujeita, na maioria das vezes, às mesmas condições de qualquer outra forma de produção mercadológica. Essa especialização da função, sua sujeição ao mercado, fez com que o romance, naquela época, se transformasse também em comércio. Assim, a rejeição do público e a popularidade transformaram-se nos padrões de mérito de uma obra ou autor. Na mesma linha de pensamento, Tom Moore acabou por fazer a distinção entre o que era a "multidão" e as "poucas pessoas cultas". Dessa forma, "cultura" passou a ser a antítese normal para o mercado (WILLIAMS, 2011, p. 59).

A arte começou a significar um caminho para a verdade imaginativa, enquanto o artista passou a ser visto como um tipo especial de pessoa, o agente da revolução para a vida por conter em si a capacidade de ser o portador da imaginação criativa. Aqui, mais uma vez, encontra-se uma das principais fontes da ideia de cultura: a associação da ideia de "perfeição geral da humanidade" com a "prática e o estudo das artes" (WILLIAMS, 2011, p. 86). A arte era entendida como a incorporação de certos valores e capacidades 
humanas, e estava inevitavelmente ameaçada pelo desenvolvimento de uma sociedade que caminhava rumo à civilização industrial. Desse modo, por defender termos e valores opostos a essa ideia de uma humanidade geral comum, da ênfase do amor e do relacionamento, essa nova sociedade industrial estava condenada, pois partia do princípio do individualismo agressivo e das relações baseadas em fatores econômicos.

Houve uma consequência positiva da ideia de arte e cultura feita pelos idealistas românticos: entendê-las como uma realidade superior oferecia as bases para a crítica ao industrialismo. Entretanto, também houve, segundo Williams (2011) a consequência negativa: à medida que a oposição se desenvolvia, tendeu-se a isolar a arte, especializando a faculdade imaginativa nesse único tipo de atividade, enfraquecendo assim sua função dinâmica e tendendo a ligar diretamente a noção de "cultura" à de "arte".

Fica claro, para Williams (2011), que na sociedade à época da Revolução Industrial, a ideia social de cultura introduzida no pensamento inglês era sinônimo dos valores que eram independentes da "civilização", ou seja, independentes do progresso da sociedade. Por isso, Coleridge defendia a ideia de uma classe dotada cujo negócio deveria ser o "cultivo geral", isto é, uma classe que se dedicasse exclusivamente à preservação e extensão do cultivo em oposição ao progresso industrial que tomava conta da sociedade. Foram dessas noções, afirma Williams (2011), que a construção de "cultura" em termos de arte se originou.

Dando continuidade à ideia da cultura como um corpo de artes e erudição, como um espaço em que se prima pelos valores superiores em oposição ao progresso ordinário da sociedade, está Carlyle (WILLIAMS, 2011). Seguindo essa noção como uma das principais linhas de crítica à nova sociedade que emergia, enfatizava a concepção de uma "aristocracia espiritual", composta por uma minoria educada e responsável que tivesse como meta definir e enfatizar os valores mais altos que uma sociedade deve almejar. Essa ideia de uma elite formada para o bem comum da sociedade permanece, segundo Williams (2011, p. 110), até os dias de hoje. Assim, a cultura acabou sendo definida como uma entidade separada e uma ideia crítica.

Segundo Eagleton (2011), a nova ideia de cultura que se instaurou já no século XX acabou se limitando às artes ditas mais "imaginativas", como a música, a pintura e a literatura, sugerindo que os valores "civilizados" agora só podem ser encontrados na 
fantasia. De tal modo, a cultura passou a designar, assim como reforçado por Williams (2011) a erudição e as artes, atividades restritas a uma pequena porção da humanidade (EAGLETON, 2011, p. 29). A cultura, a partir desse momento, passa a significar um corpo de trabalhos artísticos e intelectuais de valor reconhecido, juntamente com as instituições responsáveis por produzir, difundir e regular esses trabalhos.

A partir dessa significação, passou a haver a distinção entre o que era produzido com fins estritamente culturais - a fim de cumprir a exigência do entendimento de que cultura seria apenas o cultivo da mente, ou seja, como artes e como o trabalho intelectual - e o que era produzido apenas com fins mercadológicos. Um exemplo disso, afirma Williams (1992), é a noção da cultura letrada como sinal de privilégio. Isso, porque com a invenção da escrita, de acordo com Williams (1992), surge junto com ela uma assimetria fundamental entre o uso desse novo meio e a participação. Essa assimetria se agrava à medida que a escrita vai ganhando cada vez mais importância, ao mesmo tempo em que a capacidade de leitura cresce a passos muito lentos. As relações entre a cultura oral e esse novo e importante setor dentro dela se tornam cada vez mais complexas, fazendo com que surja assim uma diferença qualitativa entre a área oral, que todos compartilham - ao mesmo tempo em que a maioria está confinada a ela - e a área letrada, que cresce cada vez mais em importância cultural e que é, ao contrário, privilégio de uma minoria dominante.

Posteriormente, a invenção da imprensa ampliou enormemente o acesso a uma cultura que antes ficava limitada a uma minoria, tornando-a uma cultura da maioria. (WILLIAMS, 1992, p. 107). Entretanto, criou-se a ideia/estereótipo do produtor cultural como um indivíduo, ou, mais especificamente, um autor - inclusive, a associação da palavra "autor" com o sentido de "autoridade" não é mera coincidência. Dessa forma, criam-se as distinções e privilégios desse autor dito "autônomo", em que "de um lado da divisão estão os que 'escrevem', do outro, os que 'imprimem'. O primeiro processo é considerado produção cultural, o último, meramente instrumental” (WILLIAMS, 1992, p. 114).

É nesse contexto que a maioria da população passa a ter acesso aos meios culturais; e é a partir daí que os problemas começam. Segundo Russel Nye (1982), uma cultura que estivesse ao alcance de todos, assim como suas artes derivadas, não poderia existir em um contexto sociocultural anterior ao século XVIII. É claro que é possível 
supor que um grande número de pessoas antes desse período encontrava prazer em vários meios de diversão, mas foi apenas com a emergência e ascensão da sociedade de massa no século XVIII, ou seja, a inclusão da maioria da população na sociedade, que uma cultura com caráter popular passou a existir. Em outras palavras, foi apenas com o aparecimento de uma civilização da classe média no mundo ocidental, seguido diretamente pela queda na importância da elite e na diminuição da população das classes mais baixas, que o cenário cultural se modificou radicalmente. O período, dessa forma, viu estabelecer na sociedade uma tradição artística "tripla": a arte popular (folk art, a arte folclórica de cada povo), a arte "alta" e a nova arte "pop", a última uma nova arte voltada para a massa que ascendia socialmente. Nessa nova conjuntura, a elite não mais podia legislar tão imperiosamente frente à nova e poderosa classe média.

A principal condição para o aparecimento dessa nova cultura foi o grande crescimento da população da Europa e das Américas e a consequente concentração dessa população nas áreas urbanas que apresentavam características sociais, econômicas e culturais em comum. $\mathrm{O}$ resultado de todas essas mudanças foi a criação de um enorme mercado de entretenimento que conseguia conversar com os desejos desse novo público, criando assim a chamada "indústria do entretenimento" (NYE, 1987, p. 02).

Segundo Nye (1987), quando essa revolução acabou com os padrões culturais da classe dominante, o espraiamento da educação e da alfabetização pelas demais classes acabou criando uma nova audiência que representava os gostos da população em geral, que passou a deter os meios de produção e transmissão culturais, antes dispostos apenas nas mãos de uma pequena elite privilegiada. Essa nova sociedade que se formava, mais democrática, tinha mais tempo livre e mais recursos e precisava, em consequência, de uma cultura - que não fosse a folclórica ou a de elite - que pudesse preencher esse tempo e fazer uso desse dinheiro.

Ademais, essa cultura também foi consequência do desenvolvimento tecnológico e das novas formas que possibilitaram a multiplicação dos objetos, além de métodos mais eficientes de produção e distribuição. Passando pela predominância da prensa no século XIX, o século XX alcançou um público ainda maior ao abrir outros canais de comunicação cultural - como o rádio e o cinema -, fazendo com que a cultura se tornasse acessível por meio de uma variedade de meios. Esta nova cultura acabou confirmando a experiência da maioria, tornando-se, assim, um espelho do 
comportamento, vontades e anseios da sociedade para a qual é produzida. Entretanto, como para os críticos ela é considerada de menor qualidade estética do que a arte voltada para a elite, foi descartada como um meio para se acessar a história, valores e ideias da sociedade (NYE, 1987).

Assim sendo, se a cultura, ao longo do tempo, se configurou como um fato aristocrático, de acesso limitado e possível apenas a uma pequena elite, a simples possibilidade de uma cultura partilhada por todos, que se adapta a todos e elaborada por todos, gerou uma crise na configuração. Para essa mesma elite, essa nova cultura que surgia, posteriormente denominada de "cultura de massa", acabou significando uma "anticultura" (ECO, 2008, p. 08), o sinal de uma queda de valores e crenças que seria irrecuperável. Indo na direção oposta de seus carrascos, os defensores da cultura de massa veem nela uma possibilidade de alargamento cultural, em que o acesso é maior e a circulação de uma arte e de uma cultura popular se torna possível.

No final das contas, a cerne do problema não é essa nova cultura de massa, e sim a possibilidade de acesso das massas aos demais "níveis" de cultura: é um problema político e social, de escolaridade, de possibilidade de escolha. O problema se encontra, portanto, na cultura como ferramenta de distinção e como ideologia de dominação de uma classe sobre a outra. Para tentar entender, portanto, como a definição de uma cultura entendida como "superior" por uma classe minoritária e dominante funciona como instrumento de dominação, nos debruçaremos sobre as noções de "distinção" de Pierre Bourdieu (2007) e de "ideologia" de John B. Thompson (1995).

Em A Distinção, Pierre Bourdieu (2007) afirma que os bens culturais também possuem uma economia. Para o pensador francês, indo no sentido contrário de uma ideologia carismática que entende os gostos como um dom da natureza, sendo os gostos pensados como a cultura dita "legítima", a observação científica traria outra visão a esse respeito: de que, na verdade, os gostos não são inatos, mas produto da educação, isto é, estão diretamente ligados ao nível de instrução e à origem social do indivíduo. Por isso, a hierarquia socialmente reconhecida das artes corresponde diretamente à hierarquia social dos consumidores. Assim, os gostos acabam funcionando como os marcadores privilegiados da "classe" (BOURDIEU, 2007, p. 09). Nas palavras de Bourdieu, “o gosto classifica aquele que procede à classificação; os sujeitos sociais distinguem-se pelas distinções que eles operam entre o belo e o feio, o distinto e o vulgar; por seu 
intermédio, exprime-se ou traduz a posição desses sujeitos na classificação objetiva" (BOURDIEU, 2007, p. 13).

Tendo em vista que os gostos funcionam como definidores de classe, Bourdieu (2007) ressalta, então, que a definição de uma "nobreza cultural", como explicitamos anteriormente, é apenas um pretexto para uma luta que ocorre desde o século XVII e que opõe, quase que declaradamente, grupos que possuem ideias distintas sobre a cultura, sobre a relação legítima com a cultura e com as obras de arte e, desse modo, sobre as condições de aquisição destas. Nesse sentido, a definição dominante do que seria a forma correta e legítima de apropriação cultural e da obra de arte favorece aqueles que desde cedo, seja pela origem ou pelo privilégio escolar, tiveram acesso à cultura considerada legítima.

Segundo Bourdieu (2007), a ideia de uma percepção artística que se impõe como legítima, ou seja, a disposição estética como uma capacidade de ver as obras legítimas aquilo que popularmente chamamos de um "olho bom" para identificar objetos culturais legítimos - tanto as vistas como "culturais" como as que ainda estão em vias de consagração (as chamadas "artes médias"), é uma invenção histórica, reproduzida pela educação, que surge a partir do aparecimento de um campo de produção artístico autônomo, capaz de determinar suas próprias regras, seja na produção ou no consumo de seus produtos.

O gosto funciona, portanto, como um dos pretextos para as lutas que se dão no campo tanto da classe dominante quanto no campo da produção cultural, e isso ocorre por dois motivos: primeiramente porque o julgamento do gosto é a ferramenta perfeita para que se chegue ao discernimento, que define o homem; em segundo lugar, porque a definição do que é indefinível revela o "filistinismo", a ignorância cultural, transformando o gosto no mais certeiro indício do que representa a verdadeira nobreza cultural (BOURDIEU, 2007, p. 17).

Assim, segundo Bourdieu (2007), de todos os objetos oferecidos para que os consumidores escolham, os que melhor determinam a classe são as obras consideradas legítimas, que permitem a produção de distinções em vários níveis. O gosto, ademais, é determinado pelos níveis escolares que, na maior parte das vezes, estão associados ao pertencimento a uma determinada classe social. Portanto, a distinção sobre o que é "bom" ou "ruim", "legítimo" ou "ilegítimo", é determinado pelos gostos oriundos das 
classes e a educação escolar correspondente a elas. O esforço de apropriação cultural, dessa forma, está ligado aos títulos que abrem as portas aos direitos e deveres da burguesia, enquanto o espaço em que se produz a imposição de títulos é a instituição escolar. Aqueles definidos por esses títulos, isto é, os diplomas, que os legitimam e predispõem a ser o que são, e que fazem com que suas ações sejam as manifestações superiores, dividem a função de cada um baseando-se em uma hierarquia de seres, que estão separadas por uma diferenciação de natureza, dividindo essa "nobreza cultural" dos "plebeus da cultura" (BOURDIEU, 2007, p. 28).

Destarte, essa noção de "nobreza cultural", como colocado por Bourdieu (2007) é definida a partir do gosto de um grupo, transformando-se em ferramenta de distinção social ou, em outras palavras, em ferramenta de dominação. Assim, a nobreza cultural define e aprecia a dita cultura legítima - ou a "alta cultura", em oposição à "baixa cultura, como a cultura de massa -, que se constitui, então, como uma forma simbólica que se estabelece como "ideologia", assim como na visão de John B. Thompson (1995)

Thompson (1995) reformula o conceito de ideologia ao se posicionar no sentido contrário de outros autores, que defendiam o conceito a partir de suas compreensões neutras e críticas. Thompson está menos interessado nestas concepções específicas do termo e mais interessado nas argumentações gerais sobre a natureza e o papel da ideologia nas sociedades modernas (THOMPSON, 1995, p. 75). O autor procura, dessa forma, combater a neutralização do conceito ao formular uma concepção crítica de ideologia, esta podendo oferecer as bases para um enfoque útil e defensável para a análise da ideologia, orientado para o exame concreto dos fenômenos sócio-históricos, ao mesmo tempo em que mantém o caráter crítico transmitido durante a história do termo.

A análise da ideologia, a partir da concepção proposta por Thompson, interessase inicialmente pelas maneiras como as formas simbólicas se entrecruzam em relações de poder, ou seja, "estudar a ideologia é estudar as maneiras como o sentido serve para estabelecer e sustentar relações de dominação" (THOMPSON, 1995, p. 76). Entretanto, é preciso ressaltar que fenômenos ideológicos são fenômenos simbólicos significativos desde que eles sirvam, em circunstâncias sócio-históricas específicas, para estabelecer e sustentar relações de dominação. Isso, porque diz o autor, os fenômenos simbólicos não são ideológicos em si, e sim se configuram como tal apenas quando servem, nestas 
circunstâncias particulares, para manter relações de dominação. Por isso, só se pode determinar que fenômenos simbólicos servem ou não para estabelecer e sustentar relações de dominação ao examinar as maneiras como estes fenômenos são empregados, transmitidos e compreendidos dentro de contextos sociais estruturados.

Desse modo, Thompson (1995) define "formas simbólicas" como um "[...] amplo espectro de ações e falas, imagens e textos, que são reproduzidos por sujeitos e reconhecidos por eles e outros como constructos significativos" (THOMPSON, 1995, p. 79). Caracterizar os contextos e processos como "socialmente estruturados" significa dizer que existem distinções sistemáticas no que concerne à distribuição ou ao acesso aos recursos, o que implica que pessoas situadas dentro de contextos socialmente estruturados têm, de acordo com sua localização, diferentes quantidades e graus de acesso a esses recursos. Em outros termos, Thompson (1995) afirma que a localização social e as qualificações associadas às posições de um indivíduo, em determinado contexto, fornece a estes diferentes graus de poder, entendido como uma capacidade conferida a eles socialmente ou institucionalmente, que viabiliza o poder a alguns para tomar decisões e realizar seus interesses.

Falar de dominação, portanto, é falar de relações estabelecidas de poder que são "sistematicamente assimétricas" (THOMPSON, 1995, p. 80), em que grupos particulares de agentes detêm o poder de uma maneira permanente e significativa, enquanto para outros agentes este poder permanece inacessível.

Existem inúmeras maneiras, afirma Thompson (1995), em que o sentido pode servir, dentro de condições sócio-históricas específicas, para manter relações de dominação. Para isso, identifica certos "modos de operações" gerais da ideologia a fim de apontar alguns dos modos como eles podem estar vinculados, em circunstâncias particulares, com estratégias de construção simbólica. Os modos gerais são divididos em cinco, contendo cada um deles estratégias típicas de construção simbólica. São eles: legitimação (racionalização universalização e narrativização), dissimulação (deslocamento, eufemização e tropo), unificação (estandartização e simbolização da unidade), fragmentação (diferenciação e expurgo do outro) e reificação (naturalização, eternalização e nominalização/passivização). Estas estratégias de construção simbólica são os instrumentos que possibilitam que as formas simbólicas, capazes de criar e 
sustentar relações de dominação, possam ser produzidas, facilitando assim a mobilização do sentido.

Tendo em vista tais modos e suas estratégias, o que nos interessa, para fins dessa pesquisa, é o modo chamado por Thompson (1995) de "legitimação". Relações de dominação podem ser estabelecidas e sustentadas pelo fato de serem representadas como legítimas, ou seja, como justas e dignas de apoio, como é o caso dos defensores de uma "alta cultura". A representação das relações de dominação como legítimas pode ser entendida como uma exigência de legitimação baseada em certos princípios e expressa em certas formas simbólicas e que pode, dependendo das circunstâncias, ser mais ou menos efetiva.

As formas simbólicas, desse modo, são ideológicas apenas quando servem para estabelecer e sustentar relações sistematicamente assimétricas de poder e é esse princípio, que está a serviço de grupos e pessoas em posições dominantes, que circunscreve o fenômeno da ideologia, concedendo-lhe sua especificidade e distinguindo-o da circulação de formas simbólicas em geral. Ideologia, dentro da concepção proposta por Thompson (1995), é por natureza hegemônica, pois reproduz, por meio das relações de dominação, a ordem social que favorece esses grupos dominantes. Portanto, a concepção de uma cultura verdadeira e legítima, em sua acepção culta, chamada de "alta cultura", funciona como uma forma simbólica ideológica utilizada pelas classes dominantes para se distinguirem das demais classes e legitimarem a sua própria forma de apreciação cultural, ignorando e menosprezando as demais.

Nesse sentido, o consumo cultural, como por exemplo o consumo de obras de arte, representa uma das maiores manifestações de abastança e de disposição, no sentido de condição (BOURDIEU, 2007, p. 55). A disposição estética, assim, define-se como uma espécie de gosto e, como toda espécie de gosto, ela une e separa ao mesmo tempo: sendo ela o produto dos condicionamentos associados a uma classe que possui atributos de existência específicos, une todos aqueles que possuem os mesmo atributos, e distingue-se de todos os outros, uma vez que o gosto, define Bourdieu, “[...] é o princípio de tudo o que se tem, pessoas e coisas, e de tudo o que se é para os outros, daquilo que serve de base para se classificar a si mesmo e pelo que se é classificado." (BOURDIEU, 2007, p. 56). 
O gosto, como preferência manifestada, constituiu a afirmação prática de uma diferença inevitável; inclusive, para se diferenciarem e justificarem, afirmam-se ao negar: utilizam uma recusa oposta aos outros gostos. Para Bourdieu (2007), quando se fala em gosto, toda determinação é negação, na qual os gostos se definem pela total aversão e intolerância ao gosto dos outros. Isso tudo, porque cada gosto está baseado na natureza, fazendo com que o gosto alheio seja tratado como uma contranaturalidade. A intolerância estética gera e exerce a violência, violência essa representada pela aversão aos estilos de vida diferentes, que acaba se constituindo em uma das principais barreiras entre as classes. Dessa forma, aos que acreditam ser os donos do gosto legítimo, é intolerável que haja a reunião dos gostos, pois eles, por natureza, deveriam ser separados; está aí, dado, o problema em relação à ascensão das massas e aos novos meios de comunicação de massa: a pretensão burguesa a uma "distinção natural" gera uma "absolutização" da diferença (BOURDIEU, 2007), estabelecendo assim uma relação assimétrica de poder e de dominação (THOMPSON, 1995). A cultura de massa, desse modo, está no centro dessa problemática.

\subsection{A origem da crítica à cultura de massa: os "apocalípticos"}

A cultura de massa pode ser definida, segundo Edgar Morin (2011) em A Cultura de Massas no Século XX, como aquela produzida segundo "as normas maciças de fabricação industrial; propagada pelas técnicas de difusão maciças [...] destinando-se a uma massa social, isto é, um aglomerado gigantesco de indivíduos compreendidos aquém e além das estruturas internas da sociedade (classes, família, etc.)” (MORIN, 2011, p. 04). Atingindo seu ápice no século XX, com o maior e mais rápido desenvolvimento de técnicas e tecnologias, a cultura de massa rompeu as barreiras que delimitavam o acesso à cultura de acordo com a classe social, idade e níveis de educação. Apesar de não completamente abolidas, novas estratificações foram criadas e diferentes setores instituíram para si públicos específicos. Contudo, tais estratificações não conseguiram acabar com o dinamismo particular da cultura de massa: ainda na primeira metade do século XX surge um novo tipo de imprensa, de cinema e de rádio cuja característica principal é a de se dirigir a todos (MORIN, 2011, p. 04). 
Nesse sentido, o desprezo em relação à cultura de massa que deplora a chegada desses produtos, tem origem tanto na direita quanto na esquerda: a direita a considera como um divertimento simples e digno apenas de plebeus; por outro lado, a crítica de esquerda, a partir de uma concepção marxista, considera a cultura de massa apenas como o "novo ópio do povo", como uma nova alienação da civilização burguesa, em que esta falsa cultura agora aliena o homem não apenas no trabalho, mas também no consumo e no lazer. Dessa forma, seja de direita ou de esquerda, o desprezo pela cultura de massa se dá porque ela é considerada apenas como uma mercadoria cultural feia, ordinária e sem valor artístico, levando a uma resistência geral da dita "classe intelectual” ou "cultivada" (MORIN, 2011, p. 07).

A concepção dos marxistas e seu combate contra a cultura de massa podem ser explicados pelas decepções destes com as massas. Isso, porque segundo Lazersfeld e Merton (1971), existem três fatores relacionados que são a base da preocupação do homem com os meios de comunicação de massa. Em primeiro lugar, muitos temem a onipresença e poder potencial desses meios; em segundo lugar, a preocupação com os atuais efeitos desses meios de comunicação em seu público extenso e, principalmente, que o avanço desses meios e seus efeitos possam levar ao fim das faculdades críticas e a um conformismo inadvertido; por último, o temor de que esses instrumentos tecnicamente desenvolvidos da comunicação de massa constituam uma grande abertura para a deterioração dos gostos estéticos, constituindo-se deliberadamente em canais de suprimento para gostos vulgarizados.

Estes temores, segundo os autores (LAZARSFELD; MERTON, 1971), podem conter suas origens nas mudanças sociais advindas dos "movimentos de reforma" (LAZARSFELD; MERTON, 1971, p. 235). Nesses movimentos de reforma, foram estabelecidas leis trabalhistas que diminuíram as jornadas e aboliram o trabalho infantil, além da institucionalização de uma educação universal e livre. Estes, entre outros progressos, significaram grandes vitórias para os reformistas. A partir daí, as pessoas passaram a dispor de mais tempo para o lazer, além de um acesso maior e mais fácil aos bens culturais na esperança de que, assim que livres de suas amarras, as pessoas se beneficiariam dos grandes e verdadeiros produtos culturais da nossa sociedade, como Shakespeare e Beethoven. Ao contrário, elas passaram a consumir os produtos da cultura de massa (LAZARSFELD; MERTON, 1971, p. 235). 
Para aqueles que fizeram parte do movimento reformista, esses novos meios de comunicação fraudaram os frutos das vitórias por eles alcançados. $\mathrm{O}$ ataque à cultura de massa, portanto, encontra uma de suas origens na suposta traição que se cometeu contra a instrução e a nova liberdade conseguida. Entretanto, para Edgar Morin (2011), a crítica de direita talvez tenha sido a mais condenatória e, em consequência, a que mais males tenha causado à imagem da cultura de massa. Tal crítica, segundo o autor, tem suas raízes num viés elitista e aristocrático.

Isso, porque, segundo Morin (2011), o acesso à cultura e aos objetos culturais, fossem quais fossem, ficavam retidos pelas fronteiras de classes. Desse modo, mesmo quando o camponês ou operário tiveram o primeiro acesso à cultura a partir da alfabetização, ainda assim permaneceram à margem dos demais. $\mathrm{O}$ teatro, por exemplo, continuou a ser um privilégio de consumo burguês (MORIN, 2011, p. 30). O cinema, então, foi a primeira das culturas de massa a reunir em seus circuitos espectadores de todas as classes sociais, sejam elas urbanas ou camponesas. Nesse sentido, entende-se que as fronteiras culturais são abolidas com a chegada da cultura de massa. Mais ainda: as estratificações são reconstruídas no interior dessa nova cultura. Pode-se dizer, é claro, que o cinema de "arte" e o cinema "popular", ou dos ditos "blockbusters" diferenciam o público cinematográfico, mas essa diferenciação não é a mesma que a das classes sociais. Para Morin, portanto, “[...] a cultura industrial é o único grande terreno de comunicação entre as classes sociais” (MORIN, 2011, p. 31).

Essa nova cultura, a cultura de massa, é parte do complexo formado pela economia capitalista que - mesmo com as ressalvas e críticas às deficiências e desigualdades do sistema - democratizou o consumo a partir da formação e do desenvolvimento de outro público assalariado e pela progressão de valores diferentes daqueles das sociedades com classes estratificadas. A nova cultura acabou se transformando em um "lugar comum" (MORIN, 2011, p. 33), o meio de comunicação entre as diferentes classes. Se a cultura sempre foi propriedade de uma elite, assim que ela se espalhou levou, segundo Umberto Eco (2008), o acesso das classes ditas subalternas ao controle da vida associada e o modelo cultural que prevalecia até então entrou em crise. É por isso, então, que as críticas à cultura de massa têm uma raiz aristocrática: é desprezo que apenas parece voltar-se à cultura de massa, mas que na verdade se dirige contra as massas (ECO, 2008, p. 36). 
Os críticos da cultura de massa têm um sentimento de nostalgia de uma época em que os valores da cultura eram atributo de uma classe, e não a disposição de todos. Essa nova concepção do papel e do lugar das multidões na sociedade que começou a surgir gerou o medo e o desprezo das minorias aristocráticas pelo "sórdido povo"(MARTÍN-BARBERO, 2015, p. 52). Os efeitos dessa industrialização capitalista sobre o quadro de vida das classes populares foram nítidos e a sociedade se viu afetada por movimentos de massa que, para o desespero da burguesia, colocaram em perigo os “pilares da civilização” (MARTíN-BARBERO, 2015, p. 53).

A minoria dominante acreditava que a aceitação popular condenaria a arte e que a cultura de massa, por definição, é medíocre, falsa e ruim (NYE, 1987, p. 417). Para os críticos mais ferrenhos, comenta Russel Nye (1987), a única forma de preservar a alta arte era reestabelecendo a linha que tinha se esvaído entre a aristocracia e as classes mais baixas, trazendo a arte para o controle da aristocracia e longe da intromissão popular. Nesse sentido, para melhor entender como se origina e dissemina a crítica dominante dos efeitos da mídia e da cultura de massa na primeira metade do século XX é antes de tudo necessário, segundo Bart Beaty (2005), entender a atmosfera intelectual da época.

A análise cultural dos Estados Unidos no século XX era dominada por uma única perspectiva: a tendência a comparar o gosto das diferentes audiências umas com as outras. A concepção de uma cultura elevada, a chamada "alta cultura", relacionada a uma minoria que representava uma elite cultural, era vista com alto prestígio e legitimidade, enquanto denegriam-se as escolhas culturais da maioria do público. A crítica à cultura de massa, dessa forma, baseou-se em uma gama de forças que criou relações entre arte e política (BEATY, 2005, p. 48), levando ao triunfo de uma abordagem altamente conservadora e elitista no estudo da cultura da mídia que enxerga os receptores como simples massificados.

Naquele período, a elevação dos acadêmicos dos estudos literários à posição de “analistas supremos da cultura" (BEATY, 2005, p. 50, tradução nossa ${ }^{1}$ ) se espalhou por toda a nação. Segundo Leo Rosten (apud BEATY, 2005), a crítica da cultura de massa sempre se baseou mais nas preocupações sociais, inclinações, preconceitos e pressuposições dos críticos do que por uma pesquisa empírica baseada nos variados

\footnotetext{
${ }^{1}$ Supreme cultural commentators.
} 
usos e efeitos das mídias de massa. Não obstante, apesar de seu alcance e proeminência na história norte-americana, o ponto de vista crítico da cultura de massa esteve associado com uma forma europeia particular de distinguir classes e pertencimento social por meio da cultura. A perspectiva pessimista adotada pelos intelectuais da época seguia, segundo Beaty (2005), a adoração a uma ideia de alta cultura, ou "arte genuína" (BEATY, 2005, p. 58), que poderiam mostrar como é o mundo ao mostrar como ele não é.

Nesse contexto, o posicionamento da Escola de Frankfurt em relação à cultura de massa chama a atenção. Na verdade, esse posicionamento talvez possa ser melhor entendido pelo contraste entre as visões dos outros membros com a de um associado em particular: Theodor Adorno não acreditava que a classe trabalhadora pudesse ser um agente revolucionário de mudança social (BEATY, 2005, p. 58). Com o conceito de indústria cultural, dissemina uma das críticas mais radicais feitas à cultura de massa na primeira metade do século XX que, segundo Jesus Martín-Barbero (2015), tem como base a experiência traumática do nazismo: com o regime nazista, o capitalismo deixa de ser apenas economia e passa a mostrar sua faceta política e cultural: sua tendência à totalização, em que os processos de massificação vão, pela primeira vez, ser pensados não como substitutos, mas como parte constitutiva da estrutura conflitiva do social.

O conceito de indústria cultural nasce em 1947, em texto escrito em parceria entre Adorno e Max Horkheimer (1985), contextualizando o termo não só nos Estados Unidos da democracia de massas, como também na Alemanha nazista. Pensam a dialética histórica que, partindo de uma razão ilustrada, cai em uma irracionalidade que acaba articulando o totalitarismo político e a massificação cultural como duas faces de uma mesma moeda. Parte-se da ideia de "caos cultural": perda do centro e consequente dispersão e diversificação dos níveis e experiências culturais, estas descritas e descobertas pelos teóricos da cultura de massa, afirmando assim a existência de um sistema regulador, na medida em que também a produz, da dispersão. A "unidade" desse sistema se dá, segundo Adorno e Horkheimer (1985), pela introdução na cultura da produção em série - destruindo o que distinguia a lógica da obra da lógica do sistema social - e pela imbricação entre a produção de coisas e a produção de necessidades:

\footnotetext{
2 "Genuine art"
} 
Sob o poder do monopólio, toda cultura de massas é idêntica, e seu esqueleto, a ossatura conceitual fabricada por aquele, começa a se delinear. Os dirigentes não estão mais sequer muito interessados em encobri-lo, seu poder se fortalece quanto mais brutalmente ele se confessa de público. $\mathrm{O}$ cinema e o rádio não precisam mais se apresentar como arte. A verdade de que não passam de um negócio, eles a utilizam como uma ideologia destinada a legitimar o lixo que propositalmente produzem. Eles se definem a si mesmos como indústria, e as cifras publicadas dos rendimentos de seus diretores gerais suprimem toda a dúvida quanto à necessidade social de seus produtos. (ADORNO; HORKHEIMER, 1985, p. 100)

O termo "indústria cultural" chega, portanto, para substituir o termo "cultura de massa” já que, para Adorno (1971a), este último dá a entender que essa cultura é algo que surge espontaneamente das próprias massas ou como uma forma de arte popular. Para ele, o termo indústria cultural é mais apropriado visto que essa cultura não é feita pela massa e para a massa, e sim por uma indústria acima dela que cria produtos adaptados ao consumo, determinando o mesmo. Em outras palavras, o consumidor nesse sistema não é o chefe, como a indústria cultural nos faz acreditar, pois ele não se configura como o sujeito dela, e sim como seu objeto. As massas, portanto, não seriam a medida, e sim a ideologia da indústria cultural, mesmo que essa última não possa sobreviver sem se adaptar a essas massas.

Na crítica adorniana, a indústria cultural vai mais além ao forçar a união dos domínios da arte superior e da arte inferior, que por muitos anos permaneceu separada. Essa união, no caso, só causaria prejuízo para ambos os lados: "a arte superior se vê frustrada de sua seriedade pela especulação sobre o efeito; a inferior perde, através de sua domesticação civilizadora, o elemento de natureza resistente e rude, que lhe era inerente enquanto o controle social não era total” (ADORNO, 1971a, p. 288).

Todas as práticas da indústria cultural transferem as motivações voltadas ao lucro para as criações artísticas. Assim, a autonomia das obras de arte, apesar de nunca ter sido pura e completa, se vê completamente abolida pela indústria cultural. As produções do espírito passam a ser completamente mercadorias. O termo "indústria", dessa forma, não deve ser entendido de maneira literal. Ele designa, segundo Adorno (1971a), a estandartização de qualquer produto e a racionalização das técnicas de distribuição, mas não se refere necessariamente ao processo de produção. 
Para o pensador, a ideia de que o mundo quer e gosta de ser enganado é hoje mais verdadeira do que nunca. Se os próprios defensores da indústria cultural, diz ele, objetam à ideia de que ela pretende ser arte, isso constitui-se como ideologia ao querer eximir-se da responsabilidade em relação à base de seu negócio. As ideias que ela coloca em ordem são, sempre, as do status quo, aceitas sem objeção ou análise e, por isso,

Assim como mal podemos dar um passo fora do período de trabalho sem tropeçar em uma manifestação da indústria cultural, os seus veículos se articulam de tal forma que não há espaço entre elas para que qualquer reflexão possa tomar ar e perceber que o seu mundo não é o mundo. [...] Quanto mais completo o mundo como aparências, tanto mais inescrutável a aparência como ideologia. (ADORNO, 1971b, p. 347)

A técnica dessa indústria conquista seu poder sobre a sociedade, em que a racionalidade técnica se transforma em racionalidade da dominação. Por meio desta ideologia, a indústria cultural consegue substituir a consciência pelo conformismo, pois a ordem por ela estabelecida nunca é confrontada. As considerações impostas pela indústria cultural não podem ser consideradas normas para uma vida feliz, pois são apenas conformações advindas dos interesses dos poderosos. Por conta disso, ocorreria inevitavelmente a atrofia da imaginação e da espontaneidade de quem consome os produtos da indústria cultural, paralisando suas capacidades (ADORNO; HORKHEIMER, 1985, p. 105).

Nesse sentido, entendemos que para Adorno, “a massa é representada por pessoas que participam de um comportamento de massa [...]" (BLUMER, 1971, p. 178) e só. O indivíduo, exposto a esses meios de comunicação de massa, torna-se inevitavelmente alienado diante da realidade e não consegue mais pensar por si, necessitando de algo que venha de cima para iluminar suas ideias. Para Adorno, na verdade, mesmo que se possa considerar que as mensagens transmitidas pela indústria cultural são inofensivas, o comportamento que ela transmite não é. Isso, porque a “satisfação compensatória" (ADORNO, 1971a, p. 294) que ela oferece aos indivíduos ao dar a falsa impressão de que o mundo está em ordem, frustra-os na própria ideia de 
felicidade que ela enganosamente propicia. Ela impede, assim, que os indivíduos sejam autônomos, independentes e capazes de julgar e de tomar decisões por conta própria.

Entretanto, Robert Witkin (2003) nos lembra que Adorno nunca deixou de reconhecer que havia artistas talentosos e habilidosos trabalhando dentro do sistema da indústria cultural. O problema, para ele, não era esse, mas aos interesses que serviam esses artistas e os usos que eram feitos de seus trabalhos. O maior problema de Adorno, portanto, é que, em sua visão, a cultura deveria ser uma ferramenta de mudança e autodesenvolvimento do indivíduo. Ao contrário, a indústria cultural, o que o pensador chamava de "pseudo-cultura", como produto do mercado capitalista, servia apenas para manter as pessoas na linha, em uma escravidão conformada, neutralizados (WITKIN, 2003, p. 30).

A crítica à cultura de massa, entretanto, não se encerra em Adorno. Muitos outros autores da época perpetraram a mesma visão, algumas vezes muito mais radicais, sobre o novo meio que surgia. Seguindo a mesma linha da crítica adorniana, por exemplo, Bernard Rosenberg (1957) afirma em A cultura de massa nos Estados Unidos que "na pior das hipóteses, a cultura de massa ameaça não só cretinizar o nosso gosto, mas também brutalizar os nossos sentidos, ao mesmo tempo em que abre caminho para o totalitarismo" (ROSENBERG, 1957, p. 22).

A crítica de José Ortega y Gasset (2013) no livro A rebelião das massas talvez seja uma das mais severas. Logo nas primeiras páginas desta que é considerada sua obra prima, Ortega y Gasset (2013) aponta que o problema central da nossa sociedade é a ascensão ao poder do "homem de massa". Para ele, a massa não respeita mais os valores da elite portadora de cultura e busca desbancar tais valores e impor os seus próprios. A massa, na visão do autor, avançou para o primeiro plano da vida social e passou a gozar dos lugares, instrumentos e prazeres que antes eram reservados a poucos. O autor chega a ponto de constatar que os lugares não são destinados à multidão, pois esses não conseguem acomodá-la em seu espaço, causando o transbordamento do mesmo. Esse novo fenômeno de ascensão das massas está “[...] suplantando as minorias" (ORTEGA Y GASSET, 2013, p. 43). Para Ortega y Gasset, a vulgaridade tomou conta da sociedade, e é a massa que proclama o direito à vulgaridade e tenta impô-la a todo custo. Na ideia de estandartização, ainda assinala que a massa esmaga tudo aquilo que é diferente, individual, excelente, seleto e qualificado. Quem não pensar e agir como todo 
o mundo, pode até mesmo ser eliminado. 'E claro que esse 'todo o mundo' não é 'todo o mundo'. 'Todo o mundo' era, normalmente, a unidade complexa de massa e minorias discrepantes, especiais. Agora todo o mundo é só massa” (ORTEGA Y GASSET, 2013, p. 44, grifo do autor).

Já na visão de Dwight Macdonald (1957), durante quase um século a cultura ocidental foi dividida em duas: o que ele chama de "gênero tradicional", ou simplesmente a "Alta Cultura", e a "cultura de massa", manufaturada por atacado para o mercado. A cultura de massa, para Macdonald, desenvolveu meios próprios em que o "artista sério" não se aventura: esses meios são a televisão, o cinema, o rádio e, como esperado, as histórias em quadrinhos. A cultura de massa se desenvolve, segundo MacDonald (1957), a partir da democratização política e do crescimento da educação popular no final do século XIX, que quebram as barreiras do antigo monopólio da cultura nas mãos da classe superior. As empresas encontraram nesse desenvolvimento um mercado lucrativo a partir das demandas culturais dessa massa e, aliado com o avanço tecnológico, tornou possível a produção barata e em série de livros, jornais, música e quadrinhos, todos em quantidade suficiente para dar conta do novo mercado que surgia. Além disso, novos meios de comunicação nascidos desse avanço tecnológico puderam surgir, como o cinema e a televisão.

Macdonald (1957) faz sua crítica partindo da premissa de que a cultura de massa, ou o "kitsch" - palavra alemã que designa a cultura de massa (MACDONALD, 1957, p. 78) -, suprimem a "alta cultura", extraindo dela sua riqueza e não the dando nada em troca. Os "senhores do kitsch" (MACDONALD, 1957, p. 78) exploram as necessidades culturais das massas com o intuito de obter lucro e/ou manter o domínio da sua classe. A partir daí, faz a diferenciação entre a arte folclórica e a cultura de massa: a primeira era uma expressão espontânea, natural, feita pelo e para o povo e sem intervenção da alta cultura; a segunda é imposta, vem de cima. Para Macdonald, a arte folclórica era o mundo particular do povo, em que a alta cultura não poderia interferir; era a separação clara entre povo comum e aristocracia. A cultura de massa, entretanto, derrubou o muro que os separavam fazendo com que o povo agora ficasse refém da alta cultura e convertendo-a, dessa forma, em instrumento de dominação política.

Para Macdonald (1957), a cultura de massa é de fato uma força dinâmica, revolucionária, que quebra as velhas barreiras de classe, gosto e tradição e assim acaba 
com as distinções culturais. Ao fazer isso homogeneíza e, ao homogeneizar, destrói todos os valores já que, para ele, determinar valor pressupõe discriminação. A cultura de massa, dessa forma, é sim muito democrática, pois se recusa a discriminar quem ou o que quer que seja. Afinal, "tudo é grão para o seu moinho e tudo sai de lá, de fato, muito bem moído" (MACDONALD, 1957, p. 81). A ascensão da cultura de massa não significa a sua elevação, seu engrandecimento. Na verdade, significa apenas a corrupção da alta cultura. Ora, "nada é mais vulgar do que o kitsch sofisticado" (MACDONALD, 1957, p. 83).

A crença desses e de tantos outros autores no mito que a cultura irá declinar se a massa ascender revelou que a cultura de massa acabou se tornando o receptáculo de um problema cultural sério no período pós-Segunda Guerra: a briga entre a conservação da elite e ascensão das massas (SELDES apud BEATY, 2005, p. 73).

Esses críticos do início do século XX que se opunham e combatiam a cultura de massa, em defesa da "alta cultura" de que fala Macdonald, têm sua raiz aristocrática, segundo Edgar Morin (1986) em dois tipos de elitismo que partilham a cultura ilustrada, ao mesmo tempo em que a disputam: o das classes privilegiadas e o da intelligentsia criadora-crítica. A primeira, como já colocamos, diz respeito a uma classe privilegiada que se apropria da fortuna cultural, na qual o elitismo burguês coloniza a instituição cultural. Tal colonização só é possível assimilando o código, ao qual a apropriação se torna um teste e um perigo social: se ser culto é pertencer à elite, as classes superiores começam a se sentir ameaçadas pelas camadas populares em ascensão e que entendem a cultura como elevação social, e assim buscam preservar seu elitismo "[...] levando-o às últimas trincheiras do esnobismo e da moda" (MORIN, 1986, p. 83). A segunda é um elitismo da intelligentsia, que se caracteriza como a classe, nas sociedades modernas, que produz, sustenta e renova não só a cultura ilustrada, como também a religiosa, a nacional, entre outras.

Em Os Intelectuais como Classe Social, Nildo Viana (2006) coloca que os termos "intelectuais", "intelectualidade" e "intelligentsia" representariam, no discurso cotidiano, algo ligado à inteligência, alguém inteligente. $\mathrm{O}$ termo intelligentsia, apesar de mais formalmente próximo a esse sentido, é, contudo, considerado como uma referência negativa em relação aos intelectuais. Teoricamente falando, afirma o autor, os intelectuais não se caracterizam por sua grande inteligência, como é comumente 
pensado, e sim por sua posição no conjunto das relações sociais, sendo definidos, pensando em termos de divisão social do trabalho, como uma classe social de indivíduos que se dedica exclusivamente ao trabalho intelectual. Embora assumam posições diferentes dependendo da sociedade em que estão inseridos, os intelectuais sempre gozaram de posição privilegiada no interior da divisão social.

Seja qual for a sociedade da qual fazem parte, os intelectuais sempre possuíram remuneração maior do que as classes exploradas. Assim sendo, constituem-se como uma classe social que ocupa um papel específico no processo de reprodução da sociedade e os privilégios oriundos desta relação. Apesar dessas semelhanças, sua constituição e forma de ação dependem das relações sociais e modo de produção da sociedade da qual fazem parte, revelando que também existem diferenças entre os grupos de intelectuais de acordo com o contexto do qual fazem parte. Outro ponto em comum entre os intelectuais é que em qualquer sociedade, além de se dedicarem exclusivamente ao trabalho intelectual, são parte das classes privilegiadas, atuando como uma "classe auxiliar" da classe dominante (VIANA, 2006).

Tendo como função a produção e/ou reprodução de saberes que são de interesse da classe dominante, os intelectuais, "[...] por sua função social e os interesses e valores derivados dela, são agentes da conservação, e não da transformação" (VIANA, 2006). Assim, a suposta "liberdade" e "autonomia" usufruídas pelos intelectuais na verdade são uma farsa. Seus interesses particulares estão sempre ligados aos da classe dominante, da mesma forma que seus privilégios dependem da manutenção do status social. No entanto, produzir e reproduzir o discurso da autonomia faz parte de seus interesses, pois assim garantem sua conexão com o poder e ganham legitimidade sem que se faça perceber sua subserviência em relação à classe dominante (VIANA, 2006).

Desse modo, de acordo com Morin (2011), essa intelligentsia "cultivada" é formada por esses "cultos", que entendem a cultura a partir de uma concepção valorizante, diferenciada e aristocrática, atirando a cultura de massa nos "infernos infraculturais" (MORIN, 2011, p. 07). Para a intelligentsia, toda a concepção de cultura culta, de arte, é colocada de lado com a intervenção das técnicas industriais, da determinação do mercado e da orientação para o consumo da cultura de massa. $\mathrm{O}$ capitalismo acabaria, portanto, com a grande reserva cultural, o que faz da reação da intelligentsia uma reação contra o imperialismo capitalista e a busca do lucro. 
A cultura ilustrada funciona assim como uma espécie de "supercultura" (MORIN, 1986, p. 81), o suprassumo do que a sociedade pode produzir, o que, por consequência, faz dela um produto extremamente valorizado por aqueles que a possuem e também por aqueles que não a têm. Essa extrema valorização é não só causa, como consequência do grande elitismo da cultura ilustrada. É preciso um aprendizado longo e qualidades sutis para que uma pessoa possa adquirir tais códigos, sendo eles reservados para alguns poucos. Assim, quem detém esses códigos cultos opõe-se aos "bárbaros", que são proibidos de entrar nos templos culturais, e mantém a cultura hierarquizada, preservando sua margem de superioridade. As classes privilegiadas e a intelligentsia criam, desta forma, a hierarquia que separa seus produtos culturais daqueles consumidos pela massa em ascensão. (MORIN, 1986)

Essa hierarquização, então, funciona como um exercício de poder das classes privilegiadas sobre as demais. Esse poder é, segundo Thompson (1995), entendido como a capacidade de agir com a pretensão de se atingir seus próprios interesses e objetivos; consequentemente, a capacidade de agir para atingir os próprios objetivos e interesses depende da posição do indivíduo dentro de um campo ou instituição. Thompson encontra na teoria de Pierre Bourdieu as bases para se tentar compreender o que está implicado no exercício de poder; aqui, os dois autores passam a conversar com mais clareza.

Thompson (1995) se volta à teoria dos "campos de interação" de Bourdieu para esclarecer melhor as características intrínsecas dos contextos sociais. Isso, porque como visto anteriormente, só se é possível determinar se fenômenos advindos de formas simbólicas - assim como a cultura cultivada - servem, ou não, para estabelecer e sustentar relações de dominação se analisarmos como estes fenômenos são empregados, transmitidos e compreendidos dentro de contextos sociais estruturados. Em outras palavras, Thompson (1995), ao afirmar que um campo de interação ou uma instituição social são "estruturados", quer dizer que eles são caracterizados por assimetrias e diferenças em termos de distribuição, acesso a recursos de vários tipos, poder, oportunidades e chances de vida. Portanto, analisar a estrutura social de um campo ou instituição - como o é a cultura em sua concepção valorativa- é tentar entender os critérios, categorias e princípios implícitos a ela. 
Segundo Thompson (1995, p. 195), para Bourdieu um campo de interação pode ser conceituado como um espaço de posição e como um conjunto de trajetórias. $\mathrm{O}$ campo é estruturado por um conjunto de instituições específicas, ao mesmo tempo em que as instituições são estruturadas por assimetrias e diferenças sistemáticas que constituem, em parte, a estrutura social do campo. Como consequência, indivíduos particulares se encontram em determinadas posições dentro de um espaço social e seguem, no decorrer de suas vidas, determinadas trajetórias. Tais posições e trajetórias são determinadas, até certo ponto, pelo volume e distribuição de diversos tipos de "capitais" (que podemos significar como "recursos"). Três tipos de capitais são, segundo Thompson (1995, p. 195) os mais relevantes para a análise do poder: o "capital econômico", que inclui a propriedade, bens matérias e financeiros de toda sorte; o "capital cultural", que diz respeito ao conhecimento, habilidades e diferentes tipos de qualificações educacionais e culturais; e o "capital simbólico", que se refere aos méritos acumulados, prestígio e reconhecimento associados com a pessoa ou com a posição que ela ocupa. Desse modo, dentro de qualquer campo de interação, os indivíduos baseiamse nesses diferentes tipos de capital para alcançarem seus objetivos.

Aquele "poder", enxergado a partir do nível de um campo ou instituição, é a capacidade que permite apenas um número de indivíduos tomar decisões ou realizar interesses (THOMPSON, 1995, p. 199). Esta capacidade dada de acordo com a posição no campo é tão forte que sem ela o indivíduo não seria capaz de levar para frente sua própria trajetória. Os indivíduos que mantêm certos graus de poder podem relacionar-se socialmente uns com os outros. Quando as relações de poder são sistematicamente assimétricas, esta situação é entendida como uma relação de dominação. Portanto,

Relações de poder são "sistematicamente assimétricas" quando indivíduos ou grupos de indivíduos particulares possuem um poder de maneira estável, de tal modo que exclua - ou se torne inacessível, em grau significativo a - outros indivíduos ou grupos de indivíduos, não importando a base sobre a qual esta exclusão é levada a efeito. Nesses casos, podemos falar de indivíduos ou grupos "dominantes" e "subordinados", assim como daqueles indivíduos ou grupos que, em virtude de seu acesso parcial a recursos, ocupam posição intermediária em um campo. (THOMPSON, 1995, p. 199 e 200) 
Essa divisão em classes lógicas, ou seja, entre dominantes e subordinados, causado por essas relações sistematicamente assimétricas, organiza como enxergamos o mundo social, consequência da incorporação da divisão em classes sociais. Desse modo, segundo Bourdieu (2007) as oposições mais fundamentais da estrutura das condições rico ou pobre; alto ou baixo; etc. - impõem-se como os princípios fundamentais em relação às práticas e à percepção das práticas. Assim, os estilos de vida definidores de cada classe são o produto sistemático do habitus - uma matriz geradora de comportamentos, visões de mundo e sistemas de classificação da realidade que é apreendido e gerado na sociedade e incorporado pelos indivíduos - que se tornam sistemas de sinais socialmente qualificados (o que é distinto, vulgar, etc) (BOURDIEU, 2007, p. 164). O habitus age como princípio unificador e gerador de todas as práticas; o gosto, a propensão e a aptidão para a apropriação, material e/ou simbólica de uma classe de objetos ou de práticas classificadoras e classificantes equivale à fórmula geradora que está na origem do estilo de vida, entendido por Bourdieu (2007) como o conjunto unitário de preferências distintivas que exprimem, dentro de cada um dos espaços simbólicos, a mesma intenção (BOURDIEU, 2007, p. 165).

Nesse sentido, o gosto imposto pela crítica conservadora da alta cultura funcionaria, portanto, como o operador da transformação das coisas em sinais distintivos, fazendo com que as diferenças de ordem física tenham acesso à ordem simbólica das distinções. As práticas que são objetivamente classificadas transmutam-se em práticas classificadoras, em uma expressão simbólica da posição de classe, encontrando-se na origem do sistema que define os traços distintivos, percebido, a partir de então, como uma expressão de uma classe particular e suas condições de existência, ou seja, como um estilo distintivo de vida (BOURDIEU, 2007, p. 166).

Esse estilo distintivo de vida é possível graças ao que Thompson (1995) vai chamar de "processos de valorização", uma das consequências da contextualização das formas simbólicas. Estas são frequentemente submetidas a complexos processos de valorização, avaliação e conflito. Os dois processos de valorização que possuem maior importância são, segundo Thompson: 1)“valorização simbólica": processo no qual é atribuído às formas simbólicas um determinado valor simbólico pelos indivíduos que as produzem e recebem. O valor simbólico é aquele que os objetos possuem a partir do momento em que são estimados pelos indivíduos que o produzem e recebem, ou seja, objetos que são por estes aprovados e apreciados, ou condenados e desprezados. 2) 
"valorização econômica": processo por meio do qual as formas simbólicas recebem determinado valor econômico, ou seja, valor que permite a elas serem trocadas em um mercado. Quando algo passa pelo processo de valorização econômica, passa a ser mercadoria, tornando-se objeto que pode ser comprado ou vendido por um dado preço. Essas formas simbólicas mercantilizadas são chamas por Thompson de "bens simbólicos” (THOMPSON, 1995, p. 203).

Os dois tipos de valorização carregam consigo distintas formas de conflito. Diferentes graus de valor simbólico podem ser atribuídos às formas simbólicas, de tal maneira que um objeto que pode ser apreciado por uns, pode ser completamente desprezado por outros. Thompson descreve esse fato como um "conflito de valorização simbólica" (THOMPSON, 1995, p. 204). Esses conflitos têm espaço dentro de um contexto social estruturado, caracterizado pelas já conhecidas assimetrias. Desse modo, as valorizações simbólicas oferecidas por diferentes indivíduos que têm uma posição diferenciada dentro de um contexto, raramente possuem um mesmo status. Assim, algumas valorizações possuem mais peso do que outras, de acordo com a posição do indivíduo que a determina; inclusive, se estes estiverem em uma melhor posição para oferecer valorizações, podem impô-las.

Assim sendo, segundo Thompson (1995), os indivíduos que ocupam posições dominantes dentro de um campo de interação são aqueles que são dotados (ou têm acesso privilegiado a) de recursos ou capital de vários tipos. Os indivíduos em posição dominante, ao produzir e apreciar as formas simbólicas empregam a estratégia de distinção, na medida em que procuram distinguir-se dos indivíduos ou grupos que ocupam posições subordinadas em relação a eles. Dessa forma, podem atribuir alto valor simbólico a bens que sejam raros ou caros e que são, por isso, inacessíveis àqueles que possuem menor capital econômico. Os indivíduos em posição dominante também podem usar da estratégia do menosprezo para se distinguir, ou seja, considerando as formas simbólicas produzidas por aqueles que estão abaixo deles como defeituosas ou grosseiras. A condescendência também é uma estratégia de distinção, que tem como característica o elogio das formas simbólicas com o intuito de rebaixar seus produtores e sempre lembrá-los de sua posição subordinada, possibilitando assim aos indivíduos em posição dominante reafirmar sua dominação sem declará-la abertamente (THOMPSON, 1995, p. 208). 
Por conta disso, a apropriação das obras culturais supõe disposições e competências que não são universalmente distribuídas, ou seja, que ficam nas mãos de um grupo dominante e, por isso, são o objeto de uma apropriação, material ou simbólica, exclusiva. As obras culturais, portanto, funcionam como capital cultural e, por isso, acabam funcionando como instrumento de dominação; ao garantirem, segundo Bourdieu (2007, p. 214), um ganho tanto de distinção quanto de legitimidade, revelam a característica principal da cultura legítima em uma sociedade dividida em classes: em uma sociedade em que a cultura é igualmente distribuída, o capital cultural não pode funcionar como instrumento de dominação, pois não gera a distinção entre os membros de seu grupo.

Para Bourdieu (2007), a apropriação material ou simbólica de uma obra, desta forma, gera um ganho simbólico que é determinado pelo valor distintivo que esta obra possui em questão de raridade de disposição e competência exigida para sua apreciação e distribuição entre as classes, hierarquizando assim as obras culturais. De tal modo, qualquer mudança na estrutura da distribuição de um bem ou de uma prática entre as classes, ou seja, o aumento de detentores desses bens distribuídos nas diferentes classes gera a queda no fator de raridade e no valor distintivo da obra, além de ameaçar a distinção dos antigos detentores desses produtos. Sendo que o poder distintivo das posses ou dos consumos culturais tem a tendência de diminuir na medida em que o número daqueles em condições de se apropriar deles aumenta, os ganhos de distinção chegariam ao fim se o campo de produção dos bens culturais, ainda assim regido pela lógica da distinção, não produzisse, o tempo todo, novos bens e novas maneiras de se apropriar desses bens (BOURDIEU, 2007, p. 215); daí o desespero das classes dominantes em relação ao acesso das classes mais baixas aos mesmos bens culturais a que antes somente elas tinham acesso.

Em suma, o preconceito da elite e da intelligentsia em relação à cultura de massa é uma questão social. Por sinal, lembra-nos Agnes Heller (2004), a maioria dos preconceitos é social. Isso, porque os sistemas de preconceito são criados a partir das integrações sociais nas quais vivem os homens e, sobretudo, pelas classes sociais presentes nessas integrações (HELLER, 2004, p. 50). Nesse sentido, afirma a autora, a grande maioria dos preconceitos são produtos das classes dominantes. Isso ocorre porque essas classes buscam constantemente a manutenção da coesão de uma estrutura social que lhes beneficia e tentam, inclusive, mobilizar a seu favor os membros da 
sociedade ou grupos que apresentam interesses diversos, até mesmo as classes e camadas antagônicas (HELLER, 2004, p. 54).

Fazendo uso dos preconceitos, as classes dominantes apelam à particularidade individual de cada sujeito que, por conta de seu comodismo, conformismo e conservadorismo, e até mesmo de seus interesses imediatos, transforma-se em alvo de fácil mobilização contra os interesses de sua própria integração. Nesse sentido, é importante ressaltar que a classe burguesa produz muito mais preconceitos do que todas as outras classes sociais (HELLER, 2004, p. 54). Isso ocorre não só pelo seu maior acesso a instrumentos culturais e tecnológicos, mas também, de acordo com Heller (2004) como parte de seus esforços ideológicos hegemônicos, isto é, a burguesia busca especializar sua ideologia de dominação e seu poder de distinção.

Nesse sentido, a ideia de "cultura de verdade" perpetrada pelas classes dominantes cria, segundo Morin (1986), uma oposição: o culto se opõe, ética e socialmente falando, ao inculto. A partir dessa concepção valorizada da cultura, a cultura dita "ilustrada" se opõe historicamente à chamada "cultura de massa", sendo sempre a primeira mais importante em detrimento da segunda (MORIN, 1986). Dessa forma, a cultura se transformou em um mecanismo de dominação que molda os sujeitos às necessidades de uma sociedade politicamente organizada, remodelando-os. Em outras palavras, a cultura, no sentido mais estrito do termo, tem sido usada para legitimar o poder, ou seja, usada como distinção (BOURDIEU, 2007) e como ideologia (THOMPSON, 1995) .

Para Eagleton (2011), assim como outras formas concretas de poder, a alta cultura é simplesmente uma forma de persuasão moral. Ela é uma das formas pelas quais uma ordem governante molda para si uma determinada identidade, com o intuito de intimidar tanto quanto de inspirar. Entretanto, a fronteira entre "alta" e "baixa" cultura foi corroída por mídias como o cinema e as histórias em quadrinhos, que conseguiram acumular uma bela coleção de obras-primas, ao mesmo tempo em que agradam praticamente a todos. Na realidade, não é o conteúdo da alta cultura que deveria ser problematizado, e sim sua função. O que é questionável é que ela tem sido usada como um "emblema espiritual" (EAGLETON, 2011, p. 81) de um grupo privilegiado e hegemônico. 
Esse emblema espiritual, assim, definiu as obras que poderiam ser consideradas "boas" e desprezou as que considerava "ruins". O que acabou sempre importando, portanto, não são as obras em si, mas como elas são interpretadas pelo coletivo, coisa que os próprios autores das obras não poderiam ter previsto no momento de sua produção. Afirma Eagleton que Shakespeare em si não é uma "alta cultura", o que é erudito, na verdade, são os usos sociais que são feitos da sua obra. Da mesma forma, o conteúdo dessa obra tão pouco importa, mas, sim, o que ela significa hoje. No caso, a defesa de certa "civilidade" contra as novas formas de barbarismo trazidas pelas culturas modernas (EAGLETON, 1981, p. 81)

Toda essa atenção dada aos males da cultura de massa, dentre tantos outros exemplos que poderíamos citar, era tamanha na época que Henry Rebassiere, em um artigo publicado em 1956, escreveu que as preocupações dos intelectuais com o entretenimento de massa haviam se tornado, elas mesmas, uma nova forma de cultura de massa (apud BEATY, 2005, p. 73). Beaty (2005, p.73) ainda lembra o que apontou H. Stuart Hughes em 1961: a ideia de uma cultura de massa, por si só, depende do elitismo cultural, porque foram as elites culturais que primeiro perceberam e transformaram a cultura de massa em um problema. Para Hughes, a cultura de massa não corrompe os gostos dos receptores; os intelectuais é que constantemente leram de maneira equivocada os gostos do público e erroneamente os condenaram como portadores de uma arte vulgar.

Sabemos e entendemos que, como forma de socialização adulta, os meios de comunicação de massa acabam se transformando na garantia de que certo conjunto de valores básicos permaneça visível, transformando-se em fonte de consenso e avessos à introdução de mudanças. Mais além, esses meios mantêm um consenso sociocultural não pela instituição de preceitos, mas também pela omissão: informações que poderiam trazer algum risco à estrutura sociocultural e à fé que o homem deposita nela são ocultadas ou omitidas (BREED, 1971). Dessa forma, as funções dos meios de comunicação de massa na estrutura sociocultural se voltam para o plano social: o "poder" e a "classe", como categorias estruturais, são protegidos e resguardados pela atuação desses veículos, assim como padrões culturais; da mesma forma, valores como capitalismo, religião, lar, justiça, nação, entre outros, também se transformam em itens sagrados que necessitam de sua proteção. "Os media, portanto, abstêm-se de revelações 
desnecessárias sobre as falhas estruturais na operação das instituições” (BREED, 1971, p. 225).

Contudo, generalizar é um caminho perigoso. Fatores mediadores, como o contexto social, político e econômico de determinado grupo ou nação tornam a comunicação de massa um agente colaborador, mas não a causa exclusiva em um processo de reforço das condições e ideais existentes (KLAPPER, 1971, p. 167). Segundo Joseph Klapper (1971), os meios de comunicação de massa mais parecem trabalhar em conformidade com os gostos já estabelecidos por outras vias do que capazes de determinar os gostos. O indivíduo típico, na verdade, seleciona. Dentre todas as variedades que o meio oferece, escolhe o produto que está de acordo com os seus gostos já existentes. Quando contribuem como agentes para as mudanças de gosto, dependem de outras variedades mediadoras, como a personalidade, as normas culturais e os interesses de determinado grupo (KLAPPER, 1971, p. 168/169).

Seguindo essa linha, para uma abrangente literatura sobre percepção e cognição, o organismo humano não ouve, vê ou toca simplesmente o que está a sua disposição; ao contrário, percebe o que quer perceber (RILEY JR.; RILEY, 1971, p. 125). Sendo assim, suas percepções estão ajustadas às necessidades, valores, experiências e emoções passadas por cada indivíduo. Mais uma vez, pensar no receptor da era da comunicação de massas como inegavelmente alienado é uma afirmação muito perigosa. Por isso, essa crítica parcial e execratória feita à cultura de massa começa a parecer esvaziada de sentido.

Nessa crítica à cultura de massa, tudo parece opô-la à cultura dos eruditos. Enquanto a segunda preza prela qualidade, a primeira preza pela quantidade; enquanto a primeira busca elevação estética, a segunda pensa apenas na mercadoria; enquanto uma tem como base a espiritualidade, a outra apoia-se no materialismo (MORIN, 2011, p. 08). Contudo, afirma Edgar Morin (2011, p. 09), antes de alegar com certeza que essa concepção dos cultos em relação à cultura de massa é válida, é preciso nos perguntarmos se os valores dessa "alta cultura" não são eles mesmos dogmáticos e mitificados demais. Dito isso, entendemos que tudo o que é inovador, assim como o foram o cinema, a fotografia e as histórias em quadrinhos em seu surgimento, se opõem às normas dominantes da cultura hegemônica de um período. 
A verdade é que qualquer hegemonia, apesar de ser definida sempre como dominante, jamais será total ou exclusiva, já que formas de política e cultura alternativas ou opostas podem surgir a qualquer momento na sociedade. Ampliando a noção de hegemonia de Antonio Gramsci, tratando-a especialmente no campo cultural, Raymond Williams (1979), em Marxismo e Literatura, entende que essas alternativas e outras formas de oposição e luta são importantes para mostrar o que o processo hegemônico procura controlar. Sendo tão significativas, essas ênfases políticas e culturais são tão expressivas que a função hegemônica é controlá-las, transformá-las ou incorporá-las. Neste processo, o hegemônico deve ser entendido para além de uma simples transmissão da dominação; na verdade, o processo hegemônico deve estar sempre alerta e receptivo para o que é alternativo e oposto à sua dominação. A realidade do processo cultural, portanto, deve incluir sempre os esforços e as contribuições dos que estão à margem dos termos da hegemonia vigente.

Assim sendo, mesmo que uma cultura seja hegemônica (WILLIAMS, 1979) e ideológica (THOMPSON, 1995), ela não é única e muito menos eterna; é apenas a cultura vigente da época. Por conta disso, surgem as culturas que Williams (1979) vai chamar de "residuais" e "emergentes". As culturas chamadas "residuais" se dão na medida em que qualquer cultura inclui elementos provenientes de seu passado, mas seu papel no processo cultural contemporâneo é variável. Por definição, o residual foi formado no passado, mas ainda é ativo no processo cultural, não só como parte do passado, mas como elemento efetivo do presente. Assim, certos significados e valores que não podem se expressar em termos de cultura dominante, mesmo assim ainda são vividos e praticados por meio do resíduo de uma instituição ou formação social e cultural anterior. Já o "emergente" é entendido como os novos significados, valores, práticas e relações que são continuamente criados. $\mathrm{O}$ emergente é alternativo ou oposto à cultura dominante e, por isso, assim como no caso do residual, deve ser entendido e feito com um sentido pleno do dominante. A prática cultural emergente, portanto, é inegável e, juntamente com a prática residual, constitui uma necessária e inevitável complicação da dita "cultura dominante".

Dessa forma, podemos incluir a cultura de massa no espaço de uma prática cultural emergente, considerando que a mesma funciona como uma alternativa à cultura dita superior, ao mesmo tempo em que se opõe a essa cultura, sendo essa oposição proclamada e defendida pelos próprios críticos da cultura de massa. Como uma forma 
de lutar contra a nova cultura que surge, a classe dominante se utiliza de estratégias de legitimação e, com isso, a hegemonia, para a maioria das pessoas da sociedade, acaba adquirindo um sentido de realidade (WILLIAMS, 1979), ou seja, a hegemonia não diz respeito somente aos interesses de uma classe dominante, mas também é aceita como uma realidade normal por aqueles que, na prática, são subordinados a ela (WILLIAMS, 2003, p. 160).

Isso quer dizer que uma obra pode adquirir certo grau de legitimação quando lhe é atribuído um valor simbólico, por exemplo. Isso faz com que esse trabalho seja reconhecido como legítimo não apenas por aqueles que possuem uma posição privilegiada na hora de atribuir valor simbólico, mas também por aqueles que reconhecem e respeitam a posição daqueles (THOMPSON, 1995, p. 204). A imposição da legitimidade, assim, tem como principal característica e função impedir que algum dia seja possível determinar se o dominante é visto como distinto ou nobre por ser dominante, por sua própria existência privilegiada, ou se é somente por ser dominante que ele detém essas qualidades sendo, inclusive, o único que tem o direito de defini-las (BOURDIEU, 2007, p. 88).

A legitimidade, desse modo, encontra um dos seus mais assertivos testemunhos do que de fato é na propensão dos mais desprovidos em disfarçar sua ignorância ou indiferença em relações às obras culturalmente valorizadas pela classe dominante, prestando assim homenagem a elas ao escolher em seu patrimônio o que lhes parece mais ajustado à definição do que é "legítimo" (BOURDIEU, 2007, p. 298). Por isso, dizem o que as altas instâncias querem que digam (como, por exemplo, que o teatro é melhor que o cinema, a literatura melhor que as histórias em quadrinhos, pois os segundos são diversão fácil e frívola), para se sentirem integrados dentro de uma cultura que os exclui. Por conta disso, reproduzem o discurso dominante, por mais à margem que dele estejam. Talvez seja essa a razão pela qual a crítica à cultura de massa se espraiou tão fortemente.

Segundo Umberto Eco (2008), dentre essas várias críticas à cultura de massa, é preciso destacar algumas: dirige-se a um público heterogêneo; difunde um tipo de cultura homogênea, destruindo as características próprias dos diversos grupos; não promove renovações na sensibilidade; está submetida à lei da oferta e da procura; o pensamento acaba sendo resumido em fórmula; possui uma visão passiva e acrítica do 
mundo; entorpece a consciência histórica; vicia nossa atitude; impõe símbolos e mitos, reduzindo assim a individualidade; trabalha sobre opiniões comuns e desenvolve o conformismo. A crítica mais dura, entretanto, se dá na fala daqueles que dizem que a cultura de massa coloca à disposição os frutos da dita "cultura superior", mas eles aparecem esvaziados de ideologia e crítica. (ECO, 2008, p. 40/41)

\subsection{A metacrítica: os "integrados" da cultura de massa}

Entretanto, há aqueles que defendem - ou pelo menos não desvalorizam - a cultura de massa. Dentre os defensores da cultura de massa, diz Eco (2008, p. 43), suas principais proposições são, entre outras: a cultura de massa não tomou o lugar da dita “cultura superior", e sim se difundiu em meio a sujeitos que antes não tinham acesso à cultura; ela não é típica de um sistema capitalista, e sim nasce em uma sociedade mais igualitária, em que todos os cidadãos participam dela com direitos iguais; uma homogeneização do gosto contribuiria, ao contrário do que pensam os críticos, para eliminar as diferenças de castas e unificar as sensibilidades nacionais.

Contudo, na presente análise, consideramos duas dessas proposições colocadas por Eco (2008) como as mais pertinentes para se entender melhor - não necessariamente defender, precisamos frisar - a importância da cultura de massa: 1) oferece um grande leque de informações que podem ser consumidas sem sugerir critérios de discriminação, sensibilizando o homem em relação ao universo do qual faz parte; 2) não é conservadora, pelo contrário. Pelo simples fato de constituir um conjunto de novas práticas, introduziu novos modos de se perceber e agir no mundo, configurando-se como uma renovação estilística que repercute no campo das artes ditas “superiores", promovendo o seu desenvolvimento (ECO, 2008, p. 48).

Um exemplo dos “integrados” (ECO, 2008) é, segundo Martín-Barbero (2015), o teórico Daniel Bell. Em O Fim da Ideologia, o autor coloca que a mudança não está ocorrendo mais no âmbito da política, mas no da cultura, em que todo o processo de socialização está se transformando ao se transformarem os estilos de vida. Agora, não é mais a família e nem a escola, antes redutos de ideologia, que são o espaço primordial da socialização, agora os novos mentores da nova conduta são os filmes, a televisão, a 
publicidade e as histórias em quadrinhos, que começam transformando apenas o modo de vestir e passam a metamorfosear aspectos morais muitos mais profundos. Edward Shils (apud MARTÍN-BABERO, 2015, p. 66) vai mais além: para ele, o advento da sociedade de massa não só permitiu a incorporação da maioria da população à sociedade, como também revitalizou o indivíduo, que passou a ter sua individualidade intensificada ao liberar suas capacidades morais e intelectuais, indo contra a ideia de que a massa é passiva e conformista.

Em Future Shock, Alvin Toffler (1971) comenta sobre as previsões para o futuro de muitos escritores na chamada "Revolução Superindustrial" (TOFFLER, 1971, p. 263, tradução nossa ${ }^{3}$ ). Segundo o autor, esses escritores entraram em um consenso ao preverem que nessa nova sociedade tecnológica, a humanidade se afastaria cada vez mais do ideal democrático: a máxima escolha individual, fazendo com que toda a crença na democracia e na possibilidade de decisão humana fosse relegada aos arquivos da ignorância. Nessa visão sombria do futuro, as pessoas se tornariam consumidores sem capacidade crítica, cercado por bens de consumo e escolas padronizados, reféns de uma cultura de massa padronizada que os forçaria, em consequência, a viver um estilo de vida também padronizado. Tais previsões apocalípticas acabaram por criar uma geração de pessoas cheias de fobia e ódio em relação à tecnologia ao disseminarem uma "Teoria do Desaparecimento da Escolha" (TOFFLER, 1971, p. 263, tradução nossa ${ }^{4}$ ): a ciência e a tecnologia farão do futuro um lugar ainda mais estandartizado do que o presente e o homem, progressivamente, perderia a sua liberdade de escolha.

Contudo, Toffler (1971) coloca que se, ao invés de cegamente acreditarmos nesse futuro tão obscuro e assustador, parássemos para olhar de perto o que está acontecendo, faríamos uma grande descoberta: todas essas previsões são bastante falhas ao basearem-se na mais pura ignorância sobre a natureza, o significado e as direções dessa "Revolução Superindustrial". Para o autor, o mais irônico de tudo é que as pessoas do futuro talvez não sofram com a falta de escolha, mas se tornem vítimas de um "peculiar dilema superindustrial": o excesso dela (TOFFLER, 1971, 263).

Russel Nye (1987, p. 418) ainda lembra que para Toffler, a popularização da cultura não era nem perigosa para as artes e nem mesmo degradante para o artista. $\mathrm{Na}$

\footnotetext{
${ }^{3}$ The Super-industrial Revolution

${ }^{4}$ Theory of Vanishing Choice
} 
verdade, a disseminação das artes para um público ainda mais amplo poderia influenciar fortemente tanto o nível do gosto do público quanto a relevância da arte em relação às necessidades do homem. Para Nye (1987), o espraiamento da arte não pode ser desconsiderado ou considerado como absoluto. Assim, a crítica de que uma cultura de massa ignorante iria enterrar a "boa" arte caiu por terra. $\mathrm{Na}$ verdade, pesquisas começaram a indicar que a penetração da mídia de massa na sociedade foi acompanhada de perto pelo aumento na participação do povo em todos os tipos de arte (NYE, 1987, p. 419). O século $X X$, a era dos meios de comunicação de massa, trouxe ao homem comum mais oportunidades de enriquecimento cultural do que qualquer outra época.

David Manning White (1957), em A cultura de massa nos Estados Unidos: um outro ponto de vista, propõe uma reflexão distinta da de Rosenberg (1957): essa ideia de cultura de massa como alienadora e transformadora do gosto, no caso para pior, não tem provas. Segundo o autor, não há, historicamente falando, nenhum país em que os grandes pensamentos da humanidade, nem as obras de arte consideradas mais nobres, foram aceitos por todos os estratos da população. É preciso notar, por exemplo, que no caso de Shakespeare - assim como nos lembrou Eagleton (2011) anteriormente -, por muitos considerado o maior escritor de todos os tempos, os "guardas dos altos padrões literários" (BRODBECK; WHITE, 1957, p. 262) demoraram décadas para permitirem que sua obra se elevasse a um alto grau de respeitabilidade.

Ironizando, White (1957) afirma que "esse raciocínio subentende que, não fossem esses novos diabos, os meios de comunicação de massa, e o nível da nossa vida artística seria realmente elevado." (WHITE, 1957, p. 27) Se não fosse a comunicação de massa, continua em tom satírico, os artistas não cairiam nas tentações hollywoodianas e os autores de radionovelas não precisariam escrever coisas menores e poderiam se tornar os próximos Dostoievskis. Ressalta que, no imaginário seletivo dos críticos, outros tempos e países são sempre vistos como se arte e vida fossem perfeitos sinônimos.

A crítica à crítica feita por White (1957) continua. Para ele, quando os carrascos da comunicação de massa se fazem cegos perante à contribuição trazida por esse meio, estão estimulando, eles mesmos, as banalidades que tanto desprezam. Tais críticos que enxergam a comunicação de massa como uma maldição, prefeririam uma época em que o rádio, a televisão ou o cinema não existiam e que os livros permanecessem como 
propriedades de uma pequena elite, assim como os jornais fossem tão caros que ficassem ao alcance de apenas alguns. Como não podem voltar no tempo e impedir a difusão desses meios, querem tirar do homem "comum" tudo aquilo que não condiz com seus padrões de alta cultura, ou seja, se esse homem "comum" não tem a capacidade de usufruir plenamente de tudo o que a grande arte e literatura tem a oferecer, os críticos voltam a sua indignação contra os meios de comunicação de massa (WHITE, 1957, p. 32). Aí está, mais uma vez, como a alta cultura da elite, relegada a poucos, busca controlar o gosto e determinar, a partir de seus próprios interesses e suas próprias premissas, o que é bom e o que é ruim.

Entretanto, esquecem-se esses críticos que são os próprios meios de comunicação que permitem ao homem "comum" o acesso a essa tão falada riqueza cultural, coisa que nenhum outro período da história foi capaz de fazer. Afirma White (1957) que se tudo o que esses meios oferecessem fosse uma mistura batida e estereotipada da mesma coisa, a crítica se faria válida; contudo, a diversidade e a qualidade do que é veiculado mostra que esse não é o caso.

Seguindo a mesma linha de White está Marshall McLuhan (1957). Para esse autor, um dos questionamentos à crítica da cultura de massa, em seus diferentes formatos, pode vir exatamente dos suportes em que ela se acomoda. A colonização dos Estados Unidos, país considerado como o berço da cultura de massa, teve início quando a única cultura de fato acessível a grande parte da população era o livro impresso. Por isso, segundo McLuhan (1957), até hoje associa-se cultura principalmente aos livros. Ironicamente, foi nesse mesmo país que os novos meios de imagem e de som ganharam seu maior estímulo.

Nesse sentido, McLuhan (1957) faz o seguinte questionamento: será que é exatamente porque fazem uma distinção muito grande entre o que é "cultura" e os, à época, novos meios de comunicação de massa, que os norte-americanos não conseguem enxergar esses meios como uma cultura séria? Ampliamos o questionamento de McLuhan: sendo os Estados Unidos o país que se tornou referência mundial depois da Segunda Guerra, fomos influenciados a tal ponto que mantemos a mesma opinião? Afinal, depois da Segunda Guerra, os Estados Unidos se tornaram o criador e o árbitro de praticamente tudo o que era entendido como cultura pop, já que suas empreitadas se expandiram por novos mercados ao redor de todo o globo, em um processo que, 
segundo Raymond Betts (2004), ficou conhecido como a "Cocacolonização" (BETTS, 2004, p. 03, tradução nossa ${ }^{5}$ ).

E Mcluhan continua, questionando se por causa dos quatro séculos de colonização da cultura livresca, “[...] nós nos concentramos de tal maneira nos conteúdos dos livros e dos novos meios que não podemos ver que a própria forma de qualquer meio de comunicação é tão importante quanto qualquer coisa que ela transmita" (MCLUHAN, 1957, p. 563). O autor insiste, dessa forma, para que façamos um esforço para enxergar que as revoluções nos meios de comunicação abriram como que "janelas mágicas", e que todos deveriam nelas se aventurar.

Para Jesús Martín-Barbero (2015), a cultura de massa passa, então, a ser a primeira possibilidade de comunicação entre os diferentes estratos da sociedade. E, se é impossível que uma sociedade seja completamente unificada, então é importante que haja a circulação cultural, que atingiu o seu apogeu na sociedade de massa. "Enquanto o livro manteve e até reforçou por muito tempo a segregação cultural entre as classes, o jornal começou a possibilitar o fluxo, e o cinema e o rádio intensificaram o encontro" (MARTÍN-BARBERO, 2015, p. 67). O pensamento de muitos destes autores trouxe uma nova perspectiva em relação à sociedade de massas: ela não é o fim, mas o princípio de uma nova cultura, possível graças aos meios massivos de comunicação.

Um dos eixos da cultura de massa, portanto, é o de atuar, como já demonstrado por esses autores, como uma ferramenta de democratização da cultura, apesar de este não ser seu eixo principal ou específico. Contudo, por mais que a cultura de massa possa atuar como multiplicadora das obras da alta cultura e, assim, como um agente integrador, ela não atenta contra os privilégios da alta cultura (MORIN, 2011, p. 44), pois esta ainda detém o monopólio da atualidade e originalidade. Nesse sentido, um dos maiores pontos de resistência da alta cultura é contra exatamente esta integração permitida pela cultura de massa, criando e agarrando-se a valores míticos que podem ser facilmente dissolvidos pelo grau de perfeição ao qual a reprodução atingiu. Entretanto, ao contrário do que pensam os preservadores do místico, a reprodução, para Morin (2011), na verdade supervalorizaria o original. Assim, esta mitificação pode ser considerada como uma resistência à invasão da inevitável e conquistadora cultura de massa:

\footnotetext{
${ }^{5}$ Cocacolonization.
} 
Os discos long playing e o rádio multiplicam Bach e Alban Berg. Os livros de bolso multiplicam Malraux, Camus, Sartre. As reproduções multiplicam Piero de la Francesca, Masaccio, Cézane ou Picasso. Em outras palavras, a cultura cultivada se democratiza pelo livro barato, o disco, a reprodução. (MORIN, 2011, P. 44)

No final das contas, essa orientação em direção ao consumo acaba com a autonomia e a hierarquia estética conservadas com tanto empenho pela cultura cultivada, pois, afinal, a cultura de massa insere-se profundamente na vida cotidiana e é consumida no dia-a-dia; agora, os valores artísticos não são mais diferenciados de acordo com sua dita "qualidade", e sim misturam-se em um mesmo espaço, transformando a televisão, o rádio, o cinema e as histórias em quadrinhos em universos ecléticos e prontos para receber todos os públicos e gostos. Esses novos universos advindos das culturas de massa não são mais governados e nem regulamentados, como diria Morin (2011), por uma “[...] polícia do gosto, pela hierarquia do belo, pela alfândega da crítica estética" (MORIN, 2011, p. 08). A crítica cultivada não possui mais a capacidade de governar os produtos culturais, agora determinados por seu caráter industrial e de consumação diária.

Contudo, essa defesa é, também, passível de crítica. Por isso, gostaríamos de destacar que, ao longo desse capítulo, nosso intuito não foi o de fazer uma defesa indiscriminada da cultura de massa, e sim uma crítica à ideia de uma cultura cultivada que, a fim de manter sua hegemonia perante a massa que começava a ascender socialmente, denegriu e até ridicularizou os produtos avindos dessa indústria e os desconsiderou como uma forma verdadeira de cultura. Por isso, é preciso sempre lembrar que, sendo a cultura de massa, na maioria das vezes, produzida por grupos de poder econômico e tendo como perspectiva o lucro, ela fica inevitavelmente submetida às lógicas do mercado e às leis da economia que regulam sua produção, disseminação e consumo. A cultura de massa, portanto, é um fato industrial que sofre com os condicionamentos característicos de qualquer outra atividade industrial. Eco (2008), assim, resume muito bem a definição de cultura de massa nos dois lados da moeda:

O erro dos apologistas é afirmar que a multiplicação dos produtos da indústria seja boa em si, segundo um ideal homeostase do livre mercado, e não deva submeter-se a uma crítica e a novas orientações. O erro dos apocalípticos-aristocráticos é pensar que a cultura de massa seja radicalmente má, justamente por ser um fato industrial, e que hoje 
se possa ministrar uma cultura subtraída ao condicionamento industrial. (ECO, 2008, p. 49)

A principal questão, portanto, não é se a cultura de massa é boa ou ruim, ou se ela deveria existir ou não, mas se esses meios de massa - como no caso dos quadrinhos -, são capazes de disseminar valores culturais para aqueles que a consomem, independentemente de sua origem ou de sua forma de produção. Por isso, indo em direção ao que Eco (2008) coloca, o ponto aqui é fazer uma análise crítica construtiva do meio, ao contrário dos muitos que fizeram uma análise científica da cultura de massa de forma execratória. Essa análise crítica pode, portanto,

[...] antes de mais nada, levar à correção da convicção implícita de que uma cultura de massa seja a produção de um cibo cultural para as massas (entendidas como categoria de subcidadãos), realizada por uma elite de produtores. Pode repropor o tema de uma cultura de massa como "cultura exercida ao nível de todos os cidadãos". Embora isso não signifique que cultura de massa seja cultura produzida pelas massas; não há forma de criação "coletiva" que não seja medida por personalidades mais dotadas, feitas intérpretes de uma sensibilidade da comunidade onde vivem. Logo, não se exclui a presença de um grupo culto de produtores e de uma massa de fruidores; só que a relação, de paternalista, passa a dialética: uns interpretam as exigências e as instâncias dos outros. (ECO, 2008, p. 54)

Para Morin (2011), a indústria cultural significa não tanto a racionalidade que informa essa cultura, e mais um modelo particular em que os novos processos de produção cultural se organizam. Assim, indústria cultural significa o conjunto de mecanismos e operações por meios dos quais a criação cultural se transforma em produção, demonstrando, dessa forma, um dos maiores mal-entendidos perpetrados pela visão de Adorno e Horkheimer: de que algo não pode ser considerado arte se é também indústria (MARTIN-BARBERO, 2015). Morin (2011), inclusive, coloca que a divisão do trabalho e a mediação tecnológica não são incompatíveis com a criação artística, da mesma forma que certa estandardização não significa necessariamente a total extinção da tensão criativa.

Voltemos a Umberto Eco. Quando o autor trata dos três níveis da cultura, o high, o middle e o low (ECO, 2008, p. 56), dá uma pista interessante sobre o consumo das 
histórias em quadrinhos como cultura de massa: existem produtos que, independentemente se produzidos em qualquer um dos níveis da cultura, são consumíveis em nível diverso. Em outras palavras, pertencer a um nível ou a outro não tem nada que ver com sua validade estética: um produto pode nascer no nível low e ser consumido por um vasto público que possui origens diferentes. Isso, porque suas características estruturais são tão originais e possuem tamanha capacidade de superar os limites impostos pelos circuitos de produção e consumo do qual fazem parte que podem ser julgados, por nós, como obras de arte dotadas de altíssima validade. Em suma, ter nascido dentro da cultura de massa não deveria diminuir o valor cultural de uma obra. Eco narra, dessa forma, que

\begin{abstract}
A diferença de nível entre os vários produtos não constitui a priori uma diferença de valor, mas uma diferença da relação fruitiva, na qual cada um de nós alternadamente se coloca. Em outros termos: entre o consumidor de poesia de Pound e o consumidor de um romance policial, de direito, não existe diferença de classe ou de nível intelectual. Cada um de nós pode ser um e outro, em diferentes momentos de um mesmo dia, num caso, buscando uma excitação de tipo altamente especializada, no outro, uma forma de entretenimento capaz de veicular uma categoria de valores específica. (ECO, 2008, p. 58)
\end{abstract}

Morin (2011), entretanto, reassalta que o seu objetivo não é o de exaltar a cultura de massa. Tal como ele, pensamos que colocar a cultura de massa em um altar, como se dela viessem apenas coisas boas, como se as próprias histórias em quadrinhos, como parte deste universo, só produzissem obras em alto grau de excelência, seria equivocado. Como afirma Morin (2011), seu objetivo é o de diminuir a "cultura cultivada", noção que compartilhamos na medida em que entendemos que essa preservação da cultura cultivada em detrimento da cultura de massa, desconsiderando-a como cultura, é uma forma de manutenção da intelectualidade de alguns e uma maneira de conservar a sua soberania cultural em relação a uma massa que ascende e agora tem acesso aos bens culturais.

Em suma, o que queremos dizer é que não há problemas em ser fruto da cultura de massa. Ser produto dessa "indústria cultural" não deveria diminuir o valor cultural de uma obra. Jesus Martín-Barbero acaba resumindo bem o que queremos dizer: "quando 
a crítica da crise 'convoca' à crise da crítica, é o momento de redefinir o campo mesmo do debate" (MARTÍN-BARBERO, 2015, p. 97). E é isso que faremos a seguir.

\subsection{Como os quadrinhos se posicionam nessa configuração}

Bart Beaty (2012) nos lembra que a proliferação dos quadrinhos em larga escala na primeira metade do século XX caminhou lado a lado com o desenvolvimento e espraiamento dessas mesmas teorias sobre a cultura de massa que alegavam que as massas seriam uma ameaça revolucionária à ordem social estabelecida no século XIX, assim como uma ameaça totalitária no século XX. Antes de perder a força pela chegada da televisão no meio do século, seguida pelos videogames e pela internet nas décadas seguintes, os quadrinhos serviram como o perfeito exemplo de tudo o que estava errado com a cultura de massa na contemporaneidade aos olhos dos críticos que clamavam pela excelência estética, e aos dos pais que se preocupavam se os filhos estavam sujeitos a uma influência negativa.

Assim como nos demais produtos advindos da cultura de massa, o preconceito contra as histórias em quadrinhos também tem, segundo Nildo Viana (s/d), origens e consequências nas relações provenientes de uma visão racionalista e elitista: racionalista, pois busca o controle das relações sociais, a natureza e a mente humana; elitista, pois os setores mais intelectualizados da sociedade definem seus gostos e valores como superiores e os demais como inferiores, estabelecendo a oposição entre "alta" e "baixa" cultura. Partindo dessa mesma ideia, em $O$ meio contra as duas pontas, Leslie Fiedler (1957) se pergunta, tendo as histórias em quadrinhos como objeto de pesquisa, o que teriam os respeitáveis contra a cultura de massa. Para o autor, a resposta seria o problema de distinção de classes que existe em uma sociedade democrática. $O$ intelectual, dessa forma, reage com o mesmo ódio quando está diante de uma arte que parece não caber em seu entendimento e de outra que parece se recusar a alcançar o seu "nível”, como é o caso das histórias em quadrinhos.

Para a elite, a simples menção de que poderia existir mais de uma linguagem artística, e que essa linguagem não é exatamente a "arte" com que estão acostumados, perturba demais a classe que um dia sonhou com uma cultura universal baseada em seus 
próprios valores e modelos (FIEDLER, 1957). E, é claro, as histórias em quadrinhos também perturbaram a classe dominante quando do seu surgimento e posterior espraiamento. Lowenthal (1971), ao citar Coulton Waugh, autor do livro The Comics, publicado em 1947, reforça essa ideia:

Pois nos velhos tempos os artistas e escritores, bem como os artesãos,
não escreviam para atender ao povo, mas para agradar pequenos
grupos poderosos, os reis, senhores e chefes que atraíam para si o
talento da época e mantinham circunscrito aos limites dos seus
castelos e baronatos. Boa parte das belas-artes de hoje apenas
permanece viva através de tal conexão. Se tomarmos, no entanto a
civilização como um todo, esse antigo processo, sofre atualmente,
uma reversão. Há um movimento para fora. Quadros, entretenimento,
diversões, começam a ser vistos como uma legítima propriedade de
todos e as historietas em quadrinhos juntam-se a isso e refletem essa
democratização que se amplia. E, se os padrões populares são
atualmente mais baixos do que aqueles fixados por trabalhadores em
torno dos assentos dos poderosos, os artistas do povo terão a
satisfação de saber que estão identificados com um movimento vasto e
progressivo, que está dando aos homens comuns o seu direito de rir e
florescer sob o sol. (WAUGH apud LOWENTHAL, 1971, p. 300)

Dentro desse contexto, o não-valor ou baixo valor cultural relacionados às histórias em quadrinhos podem ser explicados pela influência desses estudos críticos à cultura de massa. Tais estudos, juntamente com a ideia de que as histórias em quadrinhos eram voltadas e lidas apenas pelo público infantil, originou trabalhos que afirmavam que elas teriam uma influência nefasta na formação de crianças e adolescentes. Talvez o caso mais famoso que envolve essa controvérsia seja a guerra travada contra os quadrinhos liderada pelo psiquiatra Fredric Wertham nas décadas de 1940 e 1950 nos Estados Unidos, especialmente com a publicação do livro Sedução dos Inocentes.

$\mathrm{Na}$ crítica de Wertham, faltava aos quadrinhos a seriedade artística das grandes obras: por sua onipresença derivada de sua produção em massa, por seu conteúdo sexual e violento, seriam um dos principais fatores do definhamento da sociedade civil norteamericana. Contudo, afirma Beaty (2012), o uso da retórica da cultura de massa por Wertham, teoria tão básica da época, revela como os quadrinhos eram vistos não só como infantis, mas como massificados. O ponto crucial é este: enquanto qualquer outra 
criança cresceria e passaria a consumir produtos culturais mais maduros e apropriados para sua idade, o homem das massas seria tão completamente alienado pela indústria cultural que ficaria preso ao menor denominador comum da cultura e, assim, permaneceria como uma ameaça ao desenvolvimento e amadurecimento da sociedade.

A sociedade norte-americana aderiu tão fortemente à missão perpetrada por Wertham que os prejuízos foram muitos, desde a queda nas vendas até estragos no espaço criativo do período pós-guerra (BAHIA, 2012, p. 342). Ao traçar o estabelecimento do quadro intelectual dominante para entender a cultura desse período, Beaty (2005) demonstra como os estudos de Wertham estavam diretamente ligados à atmosfera anti-cultura de massas da época. Marcio Bahia (2012) ainda reforça essa ideia ao lembrar que Amy Kiste Nyberg (apud BAHIA, 2012, p. 342), no livro Seal of Aproval, afirma que Wertham compartilhava das preocupações e conhecia as teorias sobre a cultura de massa difundidas pela Escola de Frankfurt na década de 1930.

A visão de Wertham se alinhava fortemente com os pressupostos de Adorno e de outros críticos que seguiam a mesma tradição. Para Shearon Lowery e Melvin DeFleur, dois dos maiores críticos das pesquisas feitas por Wertham sobre as histórias em quadrinhos, seus estudos eram baseados na "Teoria da Bala Mágica”, que conjecturava que todos os indivíduos eram controlados por seus instintos e que reagiriam da mesma forma que todos os outros aos estímulos recebidos pela nova mídia de massa; a mensagem da mídia, assim, entraria "como uma bala" na cabeça do espectador (LOWERY; DEFLEUR apud BAHIA, 2012, p. 342). Entretanto, assim como ressalta Nyberg (apud BAHIA, 2012, p. 342), hoje os estudos do Dr. Wertham perderam a força principalmente por não conseguirem apresentar evidências quantitativas que corroborassem suas proposições.

Também de acordo com Bahia (2012), no âmbito da opinião pública os quadrinhos ainda sofriam com os ataques de uma sociedade que queria a todo custo limpar o mundo das más influências que a cultura de massa tinha sobre a moral e os bons costumes, assim como já havia acontecido com o cinema 20 anos antes. Dentro da academia, o debate acabou monopolizado pelas pesquisas um tanto quanto controversas de Wertham. Quando incorporadas às teorias críticas da cultura de massa, que enxergavam a indústria cultural como o maior mal da sociedade e como um poderoso instrumento de manipulação, pouco se avançou no que diz respeito a pesquisas que 
vissem as histórias em quadrinhos com uma forma cultural emergente, influente e importante (BAHIA, 2012, p. 343).

Entretanto, Fiedler (1957) observa que em nenhum dos livros críticos às histórias em quadrinhos que examinou, ou mesmo nos protestos de legisladores, ou pronunciamentos morais de pastores e mães de família, encontrou uma tentativa verdadeira de se entender as histórias em quadrinhos, sua forma ou seus temas. O que mais chama atenção do autor para o ataque dos críticos é sua unanimidade, ou seja, qualquer estrato da sociedade, independentemente da posição ou cargo, faz um ataque desconcertante à cultura de massa, mesmo que não tenham mais nada em comum além disso. O sentimento que partilham? O de serem "íntegros". Para Fiedler, "essas investidas de cientistas e leigos são tão características da nossa época quanto as diatribes puritanas feitas ao teatro da era elisabetana e os piedosos protestos contra a leitura de romances no fim do século XVIII" (FIEDLER, 1957, p. 625).

Nesse sentido, Moacy Cirne (2000) nos lembra que quando falamos de cultura de massa, nunca podemos generalizar, pois a generalização é causa de uma desinformação que criará falsas leituras, questionamentos e perspectivas. Por sinal, frisa o autor, a desinformação, seja ela em relação aos bens estéticos da indústria cultural ou aos demais discursos artísticos e literários, serve apenas para gerar preconceitos e desvios ideológicos. Portanto, "dizer que a indústria cultural provoca 'atrofia da imaginação', como o fizeram Horkheimer e Adorno é simplesmente ignorar o que ela produziu de mais significativo em nosso século" (CIRNE, 2000, p. 23). Ainda segundo Cirne (2000), os quadrinhos são um campo fértil exatamente porque seu potencial estético está no interior da indústria cultural/cultura de massa. Mesmo utilizando-se, na maioria das vezes, de veículos demasiado massivos, as histórias em quadrinhos carregam consigo a possibilidade de esclarecimento artístico. Ao mesmo tempo, em sua estrutura sempre há espaço para o social, o poético e o político, bem como para o filosófico e o religioso.

Se por muito tempo as histórias em quadrinhos eram vistas apenas como uma “subliteratura" (CIRNE, 1970, p. 01), além de prejudiciais para o desenvolvimento intelectual das crianças, com o passar dos anos, contudo, a fragilidade dessas conclusões foi ficando evidente. Para Cirne (1970), a partir de uma nova base metodológica de pesquisas culturais que começou a se desenvolver, além da estrutura de sua evolução 
crítica, os quadrinhos passaram a ser problematizados a partir de sua relação com a reprodutibilidade técnica e com o consumo em massa, criando novas posições estéticoinformacionais.

Nesse sentido, no interior da mesma Escola da qual faziam parte Adorno e Horkheimer, mas em cisão com boa parte de seus postulados, Walter Benjamin esboçou algumas das chaves para se "pensar o não pensado" (MARTÍN-BARBERO, 2015, p.72). Batendo de frente com o pensamento adorniano, e pensando a experiência e técnica como formas de mediação entre as massas e a cultura, Benjamin foi pioneiro ao enxergar a mediação fundamental que permite pensar historicamente as transformações ocorridas nas condições de produção e sua clara relação com as mudanças no espaço cultural. Pensar a experiência para Benjamin é, segundo Martín-Barbero (2015) um modo de se alcançar o que eclode na história com as massas e a técnica: não se pode pensar o que acontece culturalmente com as massas sem levar em consideração a experiência delas. Pois, em contradição ao que ocorre com a cultura culta, cujo entendimento está na obra em si, na cultura de massa o entendimento encontra-se na percepção e no uso.

Em A obra de arte na era de sua reprodutibilidade técnica, Benjamin (2012) coloca que a obra de arte sempre foi reprodutível, pois tudo o que o homem produzia podia ser copiado por outro indivíduo. Ao mesmo tempo, a reprodução técnica da arte seria um processo novo que vem se desenvolvendo com o passar do tempo. A xilogravura, por exemplo, permitiu que o desenho fosse pela primeira vez reproduzido, antes mesmo que a imprensa fizesse o mesmo com o texto. Já a litografia permitiu que as artes gráficas - assim como foi o caso das histórias em quadrinhos modernas -, colocassem em massa as suas produções e sempre com novas criações. Dessa forma, as artes gráficas puderam transformar-se em instrumento de ilustração da vida cotidiana.

Continuando, Benjamin (2012) afirma que mesmo na melhor das reproduções, a autenticidade da obra de arte, que diz respeito ao aqui e agora, sua existência única, ou seja, o lugar em que ela se encontra e desdobra na história, está ausente; a autenticidade da obra é desvalorizada. Sem a autenticidade, perde-se a transmissão da tradição da obra, perde-se a aura da obra de arte. Isso significa que quanto mais algo é reproduzido, mais sua existência única se perde. Entretanto, a técnica de reprodução aproxima o indivíduo da obra, atualizando o objeto reproduzido. Tudo isso gera uma agitação na 
tradição causando uma renovação, relacionando-se diretamente com os movimentos de massa. A perda da aura, dessa figura que constitui algo único, porém distante, ocasiona a maior proximidade das coisas, algo tão buscado pelas massas na modernidade e que a reprodutibilidade finalmente permitiu. Se essa aura, esse "valor único" da obra era sempre voltado ao valor de culto, agora a arte buscada pelas massas não tem mais o caráter de devoção. Com a reprodutibilidade técnica, ocorre a "refuncionalização" da arte (BENJAMIN, 2012, p. 188).

Martín-Barbero (2015, p. 82) ao analisar a obra de Benjamin, destaca que a nova sensibilidade das massas é a da aproximação, pois acabar com a aura de cada objeto é aproximar humanamente as coisas. Continuando, salienta que é essa nova sensibilidade das massas que se expressa e se materializa nas técnicas da cultura de massa, que violam a sacralidade da aura, que tornou possível outra existência para as coisas e outra maneira de acessá-las. "A morte da aura na obra de arte fala não tanto da arte quanto dessa nova percepção que, rompendo o envoltório [...] põe os homens, qualquer homem, o homem de massa, em posição de usá-las e gozá-las” (MARTíN-BARBERO, 2012, p. 82). Antes dessa revolução, para a maioria dos homens as coisas, e não só a arte, sempre se mantiveram longe, à distância, separadas deles por um modo de relação social desigual. Agora, as massas conseguem se sentir próximas dessas mesmas coisas por meio das novas técnicas de reprodução. Esse sentir, essa experiência, diz MartínBarbero (2015) tem em seu conteúdo as exigências igualitárias que se constituem na energia presente na massa.

Nesse sentido, os quadrinhos, "nascidos no olho das técnicas de reprodução [...] beneficiam-se de uma penetração que nenhuma das artes de galerias jamais experimentou, pelo fato de que a pintura e a escultura são, originalmente, objetos não reprodutíveis." (CASTRO 6 apud CIRNE, 1970, p. 02) De fato, diz Cirne (1970), as histórias em quadrinhos surgiram como uma consequência das relações tecnológicas e sociais que, via de regra, tornam possível o complexo editorial capitalista, que se deu pela briga entre grupos jornalísticos rivais e que se configurou para o aumento das vendagens dos jornais, criando assim uma lógica própria de consumo ao aproveitar os novos meios de produção que haviam surgido.

\footnotetext{
${ }^{6}$ CASTRO, Ruy. Os quadrados contra os quadrinhos. Revista Vozes, Petrópolis, Ano 63, № 7, jul. 1969
} 
A reprodutibilidade técnica, entre outras coisas, permitiu que os novos materiais propiciassem novas possibilidades visuais. A arte, a partir daquele momento, se via substituída por tecnologias pautadas pelas necessidades criativas e sociais. Esses novos acontecimentos artísticos, baseados na fórmula "quantidade + qualidade $=$ consciência crítica” (CIRNE, 1970, p. 04) fez da massa a força motriz desse movimento. Os quadrinhos, nesse contexto, “[...] ampliaram as perspectivas de invenção \& consumo \& realidade." (CIRNE, 1970, p. 04) A refuncionalização da arte, de que falava Benjamin (2012), encontrou um de seus expoentes nas histórias em quadrinhos:

E se o cinema, ferramenta atuante da sociedade capitalista, tem como principal função revolucionária contestar antigas concepções estéticas [...], o mesmo diremos dos quadrinhos: a cultura popular situada no próprio redemoinho da cultura elétrica do nosso tempo. (CIRNE, 1970, p. 05)

Para Martín-Barbero (2012, p. 83) Adorno, por exemplo, se empenhou muito em continuar julgando as novas práticas e experiências culturais seguindo a premissa de arte que o impedia de entender o enriquecimento perceptivo trazido por qualquer uma das chamadas "culturas de massa", seja o cinema, a fotografia, ou mesmo as histórias em quadrinhos que, por sinal, definia da seguinte forma: “[...] aquelas séries de imagenzinhas de aventura semicaricaturais, que frequentemente apresentam as mesmas figuras de episódio a episódio durante anos a fio" (ADORNO, 1971b, p. 347). Toda essa nova cultura advinda da cultura de massa e de sua reprodutibilidade técnica permitiu-nos ver não exatamente coisas novas, mas uma outra maneira de ver as velhas coisas, fazendo com que pudéssemos sair da prisão cotidiana de nossas casas e locais de trabalho (MARTÍN-BARBERO, 2015, p. 83).

Assim sendo, os quadrinhos, por suas características tão próprias, por sua estrutura tão particular, ajudaram a modificar a percepção que se tinham sobre o que é a leitura e a forma de se construir o discurso. Como uma nova linguagem, não podiam e não podem se prender a parâmetros estéticos consagrados (CIRNE, 2000, p. 26). Especialmente nos anos 1960 e 1970 do século XX, os quadrinhos conseguiram "sacudir a poeira" das velhas estéticas e das velhas leituras. "Além do mais, as normas estéticas existem para serem questionadas, para serem transgredidas, para serem 
violentadas, quando for o caso, naturalmente" (CIRNE, 2000, p. 27). As histórias em quadrinhos transformaram-se em alimento de consumo de massa para cidadãos de todo o mundo; esses produtos da cultura de massa, que nasceram sem o intuito de transcendência - ou seja, sem que fossem perenes, tendo como principal característica a efemeridade -, passaram por uma grande transformação durante todo o século XX. (GASCA, 1977) A história em quadrinhos, para Dênis de Moraes (2000), resistiu aos modismos, assim como aos preconceitos, ingressando no século XXI como uma forma narrativa que engloba pluralidades estilísticas e ideológicas, mesmo sendo pautada pela lógica consumista do mercado editorial. Os quadrinhos, dessa forma, constituem um campo produtivo com moldes específicos que passa constantemente por processos de renovação.

Cirne (2000, p. 17), alerta para que, "por outro lado, não nos esqueçamos, apesar da pujança criativa de inúmeros quadrinistas, de McCay a Moebius e Luiz Gê, [que] o preconceito artístico e cultural contra as HQs ainda é inegável”. O próprio Scott McCloud (2005), um dos grandes entusiastas da Nona Arte, afirmava que tinha preconceito contra os quadrinhos. Seu preconceito, afirma o autor, se devia à visão deturpada que se tinha dos quadrinhos, inclusive chegando ao ponto de desconsiderá-los como produtos artisticamente valorizados e, em contrapartida, valorizando uma arte considerada legítima, no caso a literatura. Em Desvendando os quadrinhos, ele expõe que

\footnotetext{
Quando criança, eu sabia exatamente o que era história em quadrinhos. Quadrinhos eram revistas coloridas, cheias de arte sofrível, aventuras idiotas e sujeitos de colante. Claro que eu só lia livros de verdade. Me achava muito velho pra quadrinhos. [...] claro que eu sabia que quadrinhos, em geral, eram material de consumo infantil, com desenhos ruins, baratos e descartável... mas... não precisava ser assim! O problema era que, pra maioria das pessoas, era isso que "histórias em quadrinhos significava! Se as pessoas não compreendiam os quadrinhos, era porque tinham uma definição estreita demais sobre eles. Encontrando uma definição adequada, seria possível invalidar os estereótipos e demonstrar que o potencial dos quadrinhos é ilimitado e emocionante. (MCCLOUD, 2005, p. 02/03)
}

Mesmo quando falamos na técnica inovadora dos quadrinhos, eles permanecem indignos de designarem algo de qualidade. Segundo McCloud (2005), "as figuras em 
sequência finalmente estão sendo reconhecidas como uma excelente ferramenta de comunicação, mas ninguém ainda se refere a elas como quadrinhos! 'Diagramas' soa mais dignificante, eu suponho" (MCCLOUD, 2005, p.20). McCloud vai mais além e afirma que

\begin{abstract}
Alguns dos quadrinhos mais inspirados e inovadores do nosso século nunca tiveram reconhecimento como história em quadrinhos. Durante grande parte deste século, a expressão "história em quadrinhos" teve conotações tão negativas que muitos profissionais preferem ser conhecidos como "ilustradores", "artistas comerciais" ou, na melhor das hipóteses, "cartunistas"! E, assim, a baixa auto-estima tem se perpetuado; e a perspectiva histórica capaz de contrapor essa imagem negativa acaba sendo obscurecida por essa negatividade. (MCCLOUD, 2005, p. 18)
\end{abstract}

No fundo, articula Cirne (2000), este é um preconceito mesquinho que, na maioria das vezes, se perpetua pela mais simples e elementar desinformação. "Não estamos mais nos anos 50, mas algumas pessoas se comportam como se ainda estivéssemos nos anos 40" (CIRNE, 2000, p. 17). A crítica vazia de nada adianta; aliás, só minimiza as certezas dos críticos. Afinal, como coloca Robert Warshow sobre os quadrinhos lidos por seu filho:

Normalmente eu me recuso a ler as histórias, mas isso me coloca imediatamente em posição desvantajosa. Como posso condenar alguma coisa que não conheço? $\mathrm{E}$, às vezes, quando leio uma história, sou obrigado a conceder que essa história talvez tenha distinção mínima, e então estou perdido. (WARSHOW, 1957, p. 240)

Para Mila Bongco (2000), o grande sucesso popular dos quadrinhos, como uma mídia de massa, acabou obscurecendo sua existência anterior como uma forma de expressão. Ao se prestar atenção ao todo e ignorando exemplos isolados, os críticos se debruçaram sobre os quadrinhos como um objeto de crítica social, negando assim qualquer possibilidade de se atrelar ao meio qualidades estéticas. Entretanto, o fato dos quadrinhos serem um objeto cultural verdadeiro pode ser provado pelo grande número de publicações, nos últimos anos, que conseguem lidar com uma maior complexidade 
estética e psicológica que antes eram impensáveis para o meio. Como consequência, houve uma significativa mudança na crítica em relação aos quadrinhos como uma contribuição cultural legítima. Isso, porque as grandes possibilidades estéticas trazidas pela união de imagens e palavras nas histórias em quadrinhos têm sido cada vez mais difundidas não só no próprio meio cultural, como exploradas pelas pesquisas realizadas dentro da academia, legitimando assim os quadrinhos como uma das grandes formas de arte desenvolvidas pela indústria do entretenimento no século XX (BAHIA, 2012, p. $341)$.

Assim, apesar da queda nas vendas no início do século XXI, as histórias em quadrinhos parecem, cada vez mais, rechaçar o desdém cultural normalmente atribuído a elas, marcando sua presença como uma forma de arte expressiva no mundo contemporâneo. Segundo Bongco (2000), os quadrinhos têm recebido maior atenção não só por parte da crítica, mas também muitos artistas têm estendido as noções do que significa uma história em quadrinhos, voltando seus trabalhos para temas mais profundos e que, até algumas décadas atrás, não eram associados aos quadrinhos. Um exemplo disso é que alguns clubes de leitura respeitados nos Estados Unidos, como o Book-of-the-Month Club, passaram a colocar em suas listas histórias em quadrinhos (BONGCO, 200, p. xvi).

Os quadrinhos, dessa maneira, transgrediram as barreiras entre "alta" e "baixa" cultura e estão entrando no espaço cultural de cabeça erguida, sendo reconhecidos como um objeto cultural legítimo e agregador de valor, algo impensável até alguns anos atrás. O processo é longo e difícil, mas as histórias em quadrinhos vêm não só aumentando o respeito e a admiração dos fãs de longa data, mas também dos críticos e instituições culturais, além de receberem cada vez mais entusiastas em seu meio, entusiastas esses que perceberam que, assim como o cinema e a literatura, as histórias em quadrinhos também têm algo a dizer. Mas, como isso tudo começou? Se os quadrinhos, hoje, deixaram de ser enxergados como algo inferior diante dos grandes campos culturais, como a música e a pintura, quando essa nova perspectiva teve início? E, também, onde ela vai parar? É o que tentaremos demonstrar a seguir. 


\section{DO UNDERGROUND AO PULITZER: O INÍCIO DA VALORIZAÇÃo CULTURAL DOS QUADRINHOS}

Parece-nos importante trazer à discussão o fato de que as histórias em quadrinhos não sofreram totalmente com o desprestígio por parte dos críticos, havendo nuances nas opiniões ao seu respeito ao longo do século XX. Isso porque, de um lado, um formato parecia não atrair atenção negativa dos apocalípticos e, do outro, um movimento artístico criou a ilusão de que agora os quadrinhos poderiam ser respeitados ao levá-los para dentro dos grandes museus.

Segundo Jeet Heer e Kent Worcester (2004), s tiras, durante o século XX, tinham muito mais prestígio do que as revistas em quadrinhos. Já nos anos 1920, o formato ganhou certo grau de respeitabilidade ao apelar para o público nacional de maneira geral e ao incorporar um grande número de personagens que evocavam os indivíduos de classe média. Apesar de alguns leitores criticarem alguns trabalhos em particular, o status cultural das tiras de jornais acabou se estabilizando com o tempo, especialmente quando comparadas à revista em quadrinhos, cristalizada como um meio de comunicação de massa já na década de 1930 (HEER; WORCESTER, 2004, p. xi). Para Adam Gopnik (apud HEER; WORCESTER, 2004, p. xi), as tiras, por serem veiculadas nos jornais, já faziam parte do cotidiano das pessoas, assim como os assuntos sobre política e esporte, por exemplo, que circulavam no mesmo veículo, garantindo assim seu espaço na hierarquia cultural. Já a revista em quadrinhos era algo que exigia o deslocamento da casa até a banca de jornal e fugia ao controle parental, sendo assim passível de causar danos. Mais além, aponta Bart Beaty (2012), não se tratava apenas de um status cultural e artístico, e sim mercadológico e financeiro: os syndicates, grandes distribuidoras de tiras em quadrinhos e variedade para os jornais, pagavam muito mais do que as editoras das revistas em quadrinhos, tornando o espaço jornalístico um destino desejado por muitos artistas.

Nesse sentido, o prestígio intelectual e cultural que os jornais da época detinham e sua credibilidade junto à comunidade sancionaram as tiras de uma maneira que era praticamente impossível às revistas em quadrinhos e seus autores. Além disso, as críticas anticultura de massa disseminadas na época tinham como foco exclusivamente as revistas, enquanto as tiras dos jornais diários, lidos por toda a família, eram vistas 
como uma forma saudável de entretenimento para todas as idades e um aspecto fundamental para o desenvolvimento do jornalismo impresso. Mesmo que alguns criadores de tiras não tenham sido considerados como artistas relevantes, ainda assim eram enxergados como atributos da cultura popular norte-americana. Esta, inclusive, era uma distinção que os quadrinistas das tiras buscavam com todo afinco preservar (BEATY, 2012, p. 26).

Já a pop art foi o movimento que parecia ter finalmente dado aos quadrinhos o prestígio que eles mereciam ao inseri-los nos grandes museus de arte do mundo. Mas não foi bem assim. A pop art - apesar de ter surgido na Inglaterra na década de 1950 atingiu seu ápice na década de 1960, mas com uma diferença muito grande em relação aos outros dois movimentos que trataremos a seguir: ao invés de contribuir para o processo de legitimação das histórias em quadrinhos, pareceu ter feito exatamente o contrário. Isso, porque para muitos fãs de quadrinhos, os trabalhos de Roy Lichtenstein demonstram como os universos dos quadrinhos e das artes plásticas são percebidos e valorizados. Exemplo disso são os valores que chegaram a ser cobrados por suas obras: um dos quadros de Lichtenstein, que usa um fragmento de uma história em quadrinhos, chegou a valer US\$ 5.5 milhões. Mas, afinal, questiona Bart Beaty (2012), como uma pintura que tem como base um único painel de uma história em quadrinhos pode valer tanto, enquanto uma revista em quadrinhos inteira, com suas 52 páginas, custou originalmente, à época, algo em torno de um centavo?

Por conta disso, segundo Beaty (2012) a acusação que os fãs de quadrinhos possuem contra Lichtenstein é que o seu sucesso acabou diminuindo as chances de os quadrinhos começarem a ser levados a sério como uma forma de arte legítima por seu próprio direito, pois, ao reduzir os quadrinhos apenas a um material, uma fonte para a produção principal, Lichtenstein estaria dificultando ainda mais o caminho. A pop art, desse modo, usou gananciosamente os quadrinhos como se fossem um "objeto encontrado", uma ferramenta, um material de produção e, enquanto isso, os próprios quadrinhos eram enxergados apenas como uma "arte-irmã inferior." (SJÅSTAD, 2015, p. 06). Não obstante, o universo das artes muito comumente enxerga os quadrinistas como maus artistas ou artistas frustrados que, ao contrário de Lichtenstein, não souberam explorar seu talento da melhor forma possível (SJÅSTAD, 2015, p. 06). 
Assim, ao contrário do que muito se pensa, Lichtenstein não é considerado pelos fãs dos quadrinhos como alguém que honrou o meio, e sim como alguém que teria diminuído ainda mais o valor de todo o campo ao reafirmar o já antigo preconceito com os quadrinhos que persiste no mundo da alta arte (BEATY, 2012, p. 58). Para uma geração inteira de quadrinistas, o fato de Lichtenstein ter ganhado milhões ao explorar o trabalho de artistas das histórias em quadrinhos que ganhavam muito mal por seu ofício praticamente anônimo é bastante irritante. O que Lichtenstein conseguiu, na concepção de muitos fãs de quadrinhos, foi criar uma arte à custa da reputação dos criadores de quadrinhos e da forma em si (BEATY, 2012, p. 59). Para Art Spiegelman, Lichtenstein "fez tanto pelos quadrinhos quanto [Andy] Warhol fez pela sopa". 7

As tiras e a pop art, então, aparecem como um formato e um movimento do século XX que parecem, num primeiro momento, ser representantes da legitimação das histórias em quadrinhos no universo da cultura. Entretanto, não é bem assim. As tiras dos jornais podem até possuir prestígio desde a década de 1920, mas não contribuíram, isoladamente, para a legitimação do campo como um todo; a pop art, por outro lado, podia até vislumbrar a valorização do campo, mas acabou seguindo o caminho oposto.

Nesse sentido, acreditamos que o pontapé inicial para o reconhecimento das histórias em quadrinhos como um campo culturalmente valorizado teve início na década de 1960 a partir de dois movimentos distintos, mas que se complementaram: o reconhecimento de intelectuais e artistas europeus e o movimento underground nos Estados Unidos.

\subsection{A década de 1960: como ela modificou o que se entendia por "quadrinhos"}

Na década de 1960, tem início na Europa, espalhando-se depois pelo mundo, a "febre dos quadrinhos" (MOYA, 1977, p. 86). Livros, revistas, artigos, conferências sobre o assunto começam mais e mais a aparecer, com nomes importantes do mundo intelectual e das artes aderindo ao movimento, como Alan Renais, Pablo Picasso, Jean Luc-Godard, Federico Fellini, Pierre Alechinky, Herbert Marcuse, Marshall McLuhan,

7 did no more for comics than [Andy] Warhol did for soup. Disponível em: <http://www.bostonmagazine.com/arts-entertainment/blog/2014/05/12/art-spiegelman-boston-whathappened-to-comics/>Acesso em: 22 abr. 2016 
Francis Lacassin, Peter Foldes, Luís Gasca, Umberto Eco, Edgar Morin, entre outros. Em muitos lugares do mundo começam a circular os álbuns de luxo de histórias antigas, como Flash Gordon e Tarzan, congressos sobre o tema começam a acontecer e "o mundo todo arregala os olhos com mais de um século de atraso, compreendendo a importância dos quadrinhos no mundo atual” (MOYA, 1977, p. 87).

A partir daí, "os intelectuais, professores, pais e mestres, mães, críticos de arte, escritores e autores infantis, editores, museólogos, pedagogos, pintores, artistas plásticos, todos agora com a bênção da alta cultura, passam a dizer que nunca foram contra os quadrinhos, muito pelo contrário..." (MOYA, 1977, p. 87) Esses intelectuais europeus, especialmente os franceses, italianos e alemães, passaram a disseminar um conceito positivo sobre os quadrinhos, o que resultou no início dos estudos de Comunicação de Massa. Tais estudiosos passaram a analisar o fenômeno dos quadrinhos como um dos melhores meios de informação e de formação de conceitos visto seu papel na propaganda ideológica antinazista criada pelos norte-americanos. (LUYEN, 1987) Para Sonia Luyten (1987), esta visão mais científica e imparcial foi incorporada pelos Estados Unidos, tão logo foi possível uma reavaliação crítica e construtiva do que se tinha produzido anteriormente.

Destarte, falar de um movimento de valorização dos quadrinhos que se deu na Europa, na década de 1960, é falar do pensador italiano Umberto Eco e da publicação de Apocalípticos e Integrados. Nesse período, quanto maior era o preconceito, afirma Cirne (2004), maior e mais rica eram as descobertas sobre as potencialidades criadoras do meio. Umberto Eco, importante teórico já conhecido e reconhecido no meio das artes plásticas, concretizaria nessa época uma série de estudos, acadêmicos ou não, revelando um novo olhar sobre os quadrinhos. Um de seus mais importantes e conhecidos ensaios, intitulado O Mito de Superman, e que está presente em Apocalípticos e Integrados, representou uma ruptura fundamental na crítica dos quadrinhos, demarcando o terreno entre as críticas esporádicas e amadoras e os estudos culturais contemporâneos (HEER; WORCESTER, 2004, p. ix). 
Figura 1 - A análise quadro a quadro de Steve Canyon feita por Umberto Eco também modificou os parâmetros das pesquisas em quadrinhos

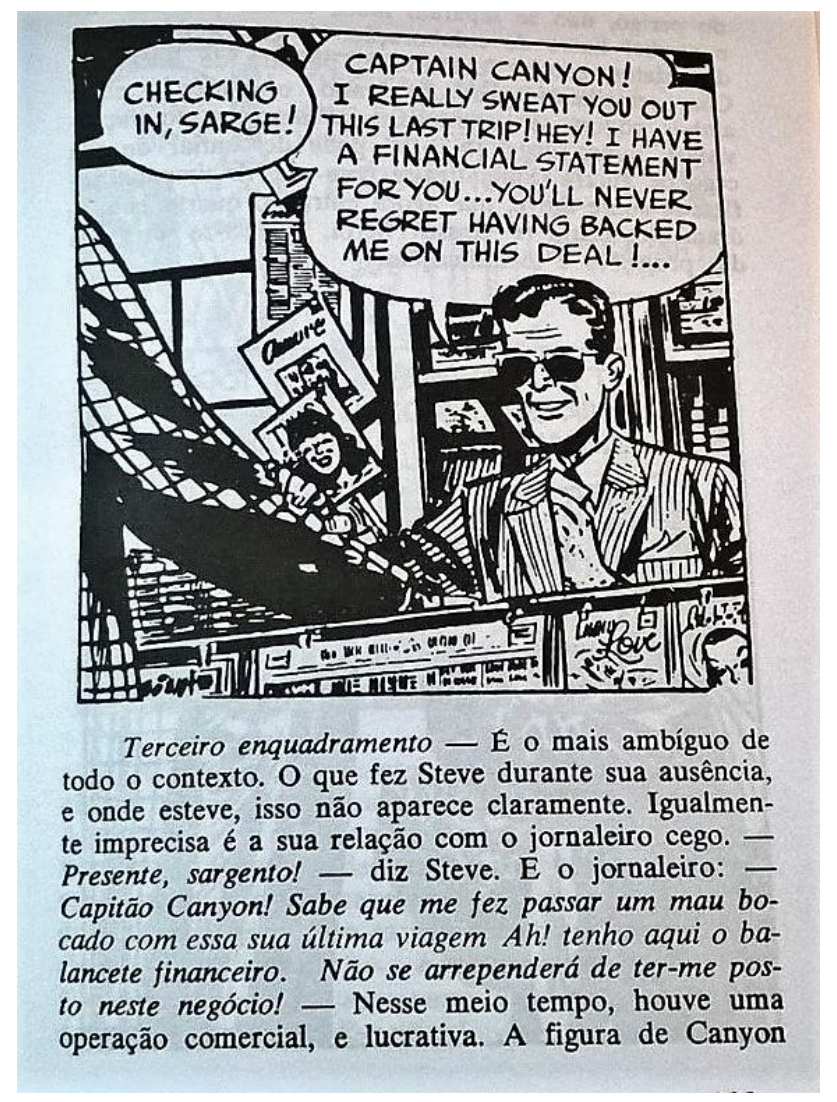

Fonte: Eco (2009, p. 133)

Para Heer e Worcester (2004, p. xviii), o pensador italiano pode ser considerado como um dos maiores exemplos de um intelectual que se posicionou contrariamente ao elitismo cultural que rejeitava e negava a cultura pop. Seus ensaios e artigos desafiavam os moralistas, cientistas e críticos culturais que temiam a cultura de massa ou que não enxergavam nada significativo nela, ajudando, assim, a cimentar as bases dos estudos culturais contemporâneos. Os escritos de críticos como Eco, reforçam Heer e Worcester (2004), juntamente com os de outros pensadores como Leslie Fiedler e Marshall McLuhan, logo floresceram como os grandes expoentes da literatura sobre os quadrinhos. 
Apocalípticos e Integrados, livro tão importante para a presente pesquisa e para tantas outras que têm os quadrinhos como objeto, tornou-se um marco, um signo desse novo olhar sobre o campo das histórias em quadrinhos. Publicado originalmente em 1964, Eco inaugurou uma nova ênfase crítica, apoiada na estética e na semiótica das histórias em quadrinhos (CIRNE, 2004), surgindo em um momento de grandes debates políticos e sociais e diversos questionamentos artísticos e culturais, um período em que a contracultura ganhava cada vez mais força.

Um exemplo da visibilidade dada ao campo na Europa é a publicação de temas que só décadas mais tarde fariam sucesso em outros países, já que estes não acreditavam que certas histórias pudessem ser contadas em formato de quadrinhos. Assim, anos antes da disseminação de quadrinhos com temáticas mais sérias e densas nos Estados Unidos, a Europa já realizava esse tipo de trabalho. Sem precisar recorrer a movimentos socialmente marginalizados, como foi o caso do underground norte-americano - que discutiremos a seguir -, os quadrinhos franceses se voltaram a temáticas sociais e políticas já nas décadas de 1960 e 1970. Especialmente na França, Bélgica, Alemanha e Itália, os quadrinhos voltados para o público adulto já eram publicados e tinham bastante força (BONGCO, 2000. p. 13).

Outro ponto que merece atenção quando falamos do pioneirismo europeu na valorização às histórias em quadrinhos está na presença do meio nos segmentos jornalístico e acadêmico. Segundo Bongco (2000), na Alemanha, por exemplo, à época e ainda hoje é bastante comum encontrar resenhas sobre obras quadrinísticas em jornais e revistas considerados importantes, enquanto que na França quadrinhos têm sido resenhados nas páginas de jornais de peso como o Le Monde, ao lado de sessões que há muitos anos enfatizam grandes produtos/produtores culturais. Além disso, cadeiras sobre o tema já eram lecionadas em universidades da Alemanha, Bélgica e Itália. Aliás, ressalta Bongco (2000, p. 13), na Universidade de Sorbonne, a disciplina de quadrinhos foi institucionalizada e introduzida pelo Instituto de Arte e de Arqueologia já em 1972, como um matéria especial designada de L'Histoire et l'Esthetique de la bande dessineé, e foi ministrada por uma das principais figuras nos estudos dos quadrinhos, Francis Lacassin. Lacassin também funda com outros grandes nomes, o Club des Bandes Dessinées, em 1962, em Paris, que seria substituído pelo Centre d'Etudes de Litteratures d'Expression Graphique, essencial para o desenvolvimento e crescimento dos estudos acadêmicos sobre quadrinhos naquele momento (BONGCO, 2000, p. 14). 
Bongco (2000) também ressalta que, na época, grande parte dos estudos críticos sobre quadrinhos foram produzidos por acadêmicos franceses, alemães e italianos, que também produziram, naquele período, alguns dos trabalhos mais importantes sobre os quadrinhos norte-americanos.

Para reforçar esse pioneirismo e proeminência de alguns países Europeus não só no reconhecimento dos quadrinhos como produto cultural legítimo, mas também nas pesquisas acadêmicas sobre o tema, Bongco (2000) cita Art Spiegelman, que afirmou certa vez que "na França, um quadrinista está apenas um passo atrás de um diretor de cinema. Nos Estados Unidos, (um quadrinista) tem apenas um pouco mais de status que um encanador" (SPIEGELMAN apud BONGCO, 2000, p. 14, tradução nossa ${ }^{8}$ ). Aliás, a própria esposa de Spiegelman, a francesa Françoise Mouly, que criou com o marido a aclamada revista Raw e que permanece no cargo de editora de arte da tradicional revista The New Yorker há mais de 20 anos, conta que esse preconceito contra os quadrinhos que ela experienciou ao chegar aos Estados Unidos foi algo completamente novo para ela, já que na França, seu país de origem, tal preconceito não existia (in CHUTE; JAGODA, 2014, p. 187).

Por sinal, segundo Kim Munson (2016), um dos responsáveis por ajudar a modificar a visão preconceituosa que as histórias em quadrinhos tinham nos Estados Unidos foi exatamente um francês: Maurice Horn, pesquisador e entusiasta dos quadrinhos, pode ser considerado, segundo Munson (2016) um dos agentes que possibilitou levar a aceitação que os quadrinhos já recebiam na Europa para os Estados Unidos. Quando Horn apareceu no mundo dos quadrinhos, na década de 1960, o cenário era de um campo obscurecido pela censura em muitas partes do mundo, inclusive em países da Europa e nos Estados Unidos. Como membro de grupos voltados às histórias em quadrinhos na França, como o Club de Bande Dessinées e o Société civile d'études et de recherché des littératures dessinnés, teve contato com grandes estudiosos franceses dos quadrinhos, como Claude Moliterni e Pierre Couperie. Ao mudar-se para os Estados Unidos, Horn tornou-se uma ponte entre este grupo de franceses e os quadrinistas norte-americanos, envolvendo-se em inúmeras e essenciais exibições que tinham como foco a arte dos quadrinhos, além de publicar livros sobre o tema entre as décadas de 1970 e 1990. Assim, a sensibilidade de Horn e a sua crença de que os

\footnotetext{
${ }^{8}$ In France, a cartoonist is one step below a movie director. In America, (a cartoonist) has only slightly more status than a plumber.
} 
quadrinhos mereciam atenção mais séria dos estudiosos ajudaram a cimentar uma nova era de apreciação e aceitação dos quadrinhos nos Estados Unidos (MUNSON, 2016, p. 01).

Os quadrinhos, até os anos 1960, eram considerados uma "arte menor" (CIRNE, 2000, p. 203). A partir dessa década, graças a esses estudos mais sistematizados e criteriosos sobre as histórias em quadrinhos que começaram a ser produzidos pelos intelectuais europeus, a imagem do campo começou a mudar. O consumo, valorização e estudo dos quadrinhos nesse período foi tão forte que até Picasso revelou certa vez que “a grande mágoa da minha vida é nunca ter feito quadrinhos" (MOYA, 1977, p. 83). Segundo Moya (1977), o que Picasso disse consegue resumir bem a importância dada ao mundo dos quadrinhos por parte dos intelectuais europeus, o que refletiu em um alto nível dos estudos destes intelectuais a respeito de tão importante meio de comunicação, dando início ao processo de legitimação. Entretanto, esse não foi o único movimento que permitiu a reavaliação e reconhecimento dos quadrinhos como produto cultural.

Do outro lado do oceano, outro movimento ajudou a iniciar o processo de valorização cultural dos quadrinhos. Mas, diferentemente da Europa, o que aconteceu nos Estados Unidos não foi uma intervenção iniciada e defendida por intelectuais e artistas que apoiavam a causa da legitimação do campo, e sim uma revolução no formato, na temática, na produção e na maneira de consumir quadrinhos. Indo contra a corrente do que se conhecia como "história em quadrinhos", o movimento underground norte-americano revolucionou o campo quanto aos temas e estilos, o que acarretou na mudança do olhar voltado ao meio no que diz respeito a suas potencialidades.

Em parte como uma reação ao Comics Code Authority (CCA) e à atitude passiva dos produtores e consumidores dos quadrinhos mainstream, surgiram nos Estados Unidos, na contracultura da década de 1960, quadrinhos que cada vez mais iam além das possibilidades temáticas e narrativas limitadas pelo código: os quadrinhos underground. Quando começaram a se tornar conhecidos, acabaram cultivando uma imagem de foras da lei com a intenção declarada de ofender as "sensibilidades da burguesia." (BONGCO, 2000, p. 06). Ao desafiarem as visões higienizadas e valores da classe média, ofereciam ao público paródias e sátiras da mídia e dos costumes sociais como alternativa ao que se consumia na época; por não estarem subjugados ao código ou à necessidade de alcançar um público amplo, os quadrinistas undergorund tinham a 
vantagem de uma liberdade artística quase irrestrita. Os "comix", como ficaram conhecidos os quadrinhos desse movimento, se tornaram a principal válvula de escape para os artistas inovadores e rebeldes que agiam contra as regras do CCA, expandindo os limites daquilo que se entendia por quadrinhos.

Figura 2 - Trabalho de S. Clay Wilson para a Zap Comix

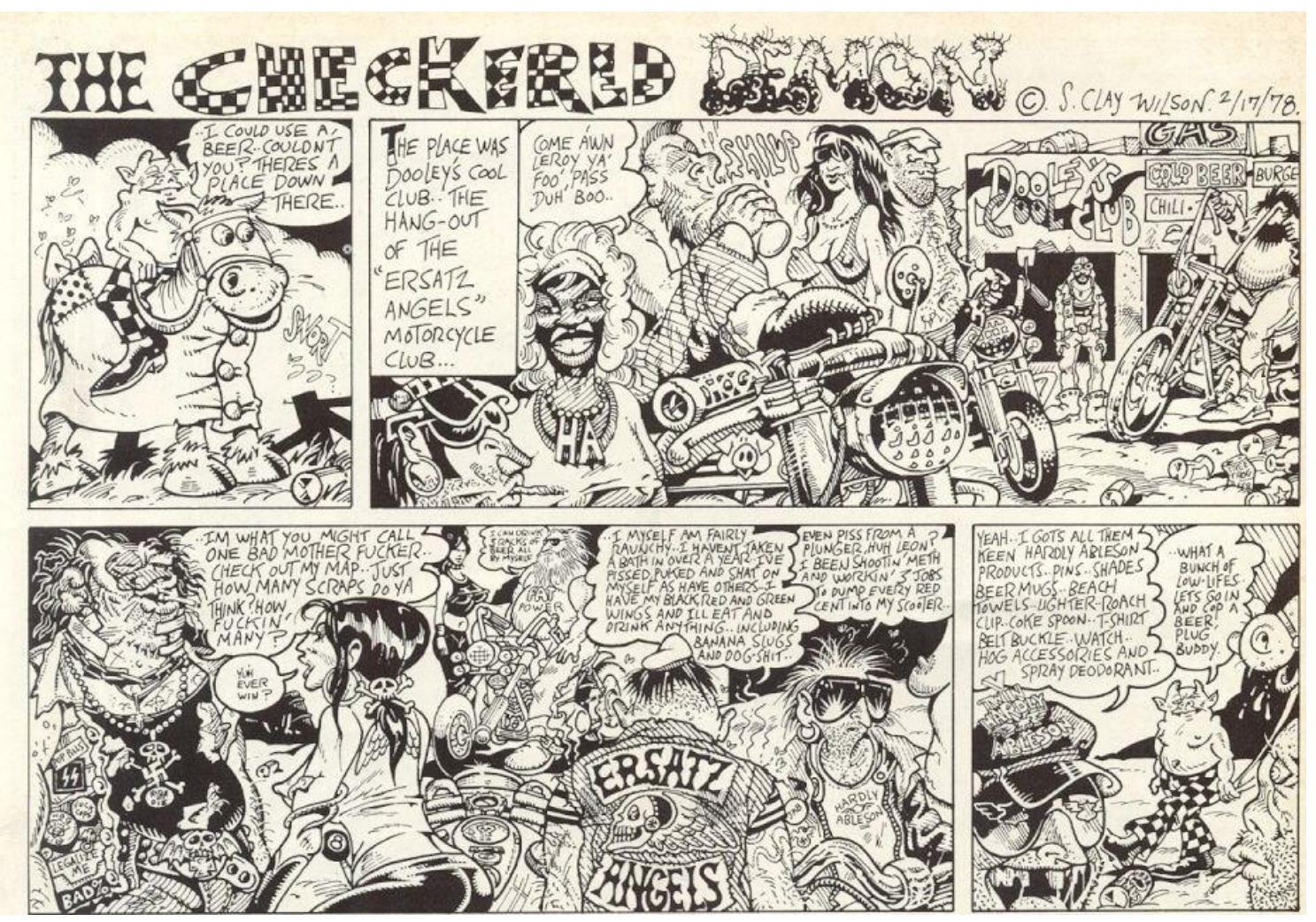

Fonte: Wilson (1978)

O surgimento dos quadrinhos undergorund norte-americanos, na década de 1960, é consequência de uma era de profundas mudanças sociais, e o conteúdo desses quadrinhos é o reflexo dessas mudanças: seus artistas puderam, a partir dali, explorar temáticas voltadas ao sexo, às drogas e à contracultura em geral de uma maneira que nunca antes foi possível, permitindo assim aos artistas e ao público leitor experimentar um novo universo. Assim, em um período em que a indústria dos quadrinhos se via presa entre as disputas das editoras e a forte censura imposta pelo CCA, que para muitos artistas significou a morte de suas integridades artísticas (BELTING, 2012), os superheróis monopolizavam o mercado. Devido ao constante medo da imoralidade, a indústria dos quadrinhos se tornou uma fábrica de super-heróis que nunca sucumbiam 
aos vícios, nunca demonstravam seus desejos sexuais e nunca matavam o vilão. Para alguns artistas, isso era inaceitável; esses seriam os artistas que dariam início ao movimento underground dos quadrinhos.

No começo, o movimento era composto apenas por um pequeno grupo de artistas de São Francisco, que deram o pontapé inicial para a criação dos quadrinhos underground. Entretanto, em pouco tempo o número de adeptos cresceu e artistas, escritores e músicos se juntaram e criaram uma rede informal de empreendedores artísticos. Enquanto, em Nova York, a lógica baseava-se nos quadrinhos coloridos e “corretos", em São Francisco, especialmente em uma área da cidade chamada de Haight-Ashbury (SKINN, 2004, p. 11), os atores do movimento que surgia faziam o possível para se desvencilharem completamente de qualquer coisa que minimamente lembrasse o mainstream, investindo em um universo subversivo, artístico, sexual, regado a drogas e à política, acabando por significar "[...] uma vibrante e tumultuada forma de arte cheia de delírios expressos vividamente e uma loucura regada à droga." (LONGHI, 2012, p. 04, tradução nossa ${ }^{9}$ ). Para aquela primeira geração, que acompanhou o nascimento do movimento, as palavras "underground comix" representavam um escape, uma resposta, uma alternativa (SKINN, 2004, p. 10).

O termo comix foi escolhido para designar os quadrinhos produzidos dentro do movimento como uma forma de diferenciá-los dos quadrinhos que eram produzidos pelos mainstream. Mesmo sabendo que, foneticamente, o som de comix e comics seria o mesmo, era preciso uma nomenclatura que os separasse, da maneira mais clara possível, do tipo de trabalho que eles não queriam fazer. Segundo o artista Jaxon, parte do movimento, o "X" em comix sugeria a classificação indicativa do quadrinho, que os americanos classificavam como X-Rated, ou seja, como voltado apenas para o público adulto (SKINN, 2004, p. 13). O uso da letra ao final da grafia servia para indicar aos leitores, logo de cara, que aqueles quadrinhos eram especiais, diferentes dos usuais.

Para Mark James Estren (2012), que vivenciou o movimento e que praticamente escreveu in loco o livro A History of Underground Comics, é praticamente impossível distinguir os quadrinhos underground apenas por sua aparência; afinal, uma das coisas mais legais deles é que vinham em diferentes formatos e estilos, especialmente no que diz respeito às técnicas de desenho: existiam desde artistas amadores até aqueles que

\footnotetext{
${ }^{9}[\ldots]$ a vibrant and tumultuous art form filled with vividly expressed delirium and drug-filled madness.
} 
desenvolviam imagens extremamente complexas, que se aproximavam ao que muitos considerariam como "arte", mas sem esquecer que, muitas vezes, um mesmo artista dava exemplo das duas coisas. Foi por conta dessa variedade de estilos, inclusive, que sugeriram que o movimento fosse definido apenas como comix (ESTREN, 2012, p. 17).

Figura 3 - Extrato de The Fabulous Furry Freak Brothers, de Gilbert Shelton

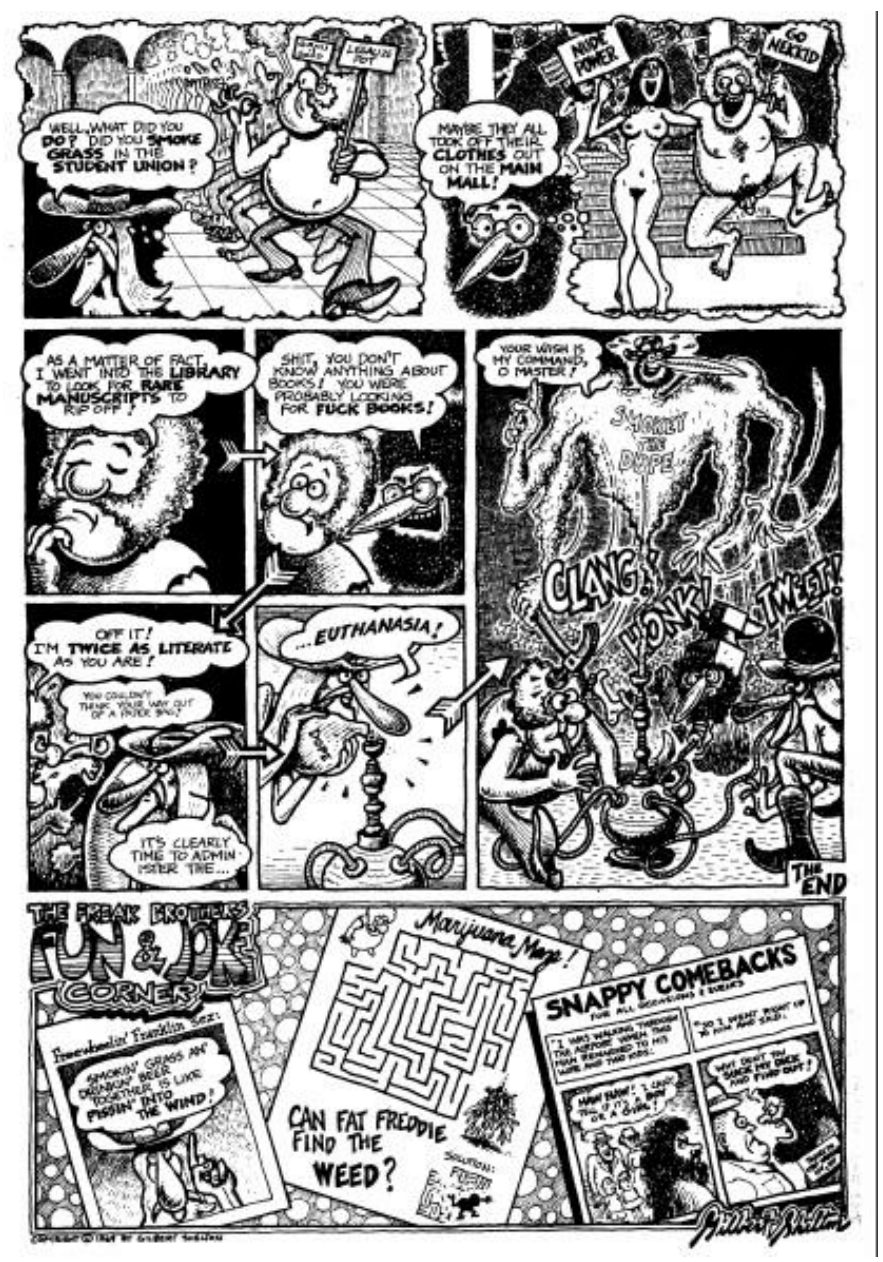

Fonte: Shelton (1971)

Estren (2012) diferencia os underground dos mainstream bem detalhadamente: os quadrinhos do underground eram produzidos às dezenas de milhares, ou menos, e não às centenas de milhares; seus artistas eram, em sua maioria, jovens e politicamente conscientes e suas formas de expressão eram normalmente contemporâneas e satíricas; cada artista era responsável por sua própria contribuição para um livro, diferente da produção em cadeia do mainstream; não havia a pressão do prazo que atrapalhava a 
criatividade do artista; aqueles quadrinhos - e aqui Estren (2012) é bastante enfático simplesmente não estavam sob o julgo e nem sua produção era determinada pelo CCA e, por conta disso, não tinham como público alvo toda a família; os artistas do movimento realmente se importavam com o que desenhavam e como desenhavam; independentemente do assunto tratado, os artistas não tinham nenhum compromisso com questões visuais ou verbais que pudessem ofender, e por isso nas suas capas sempre constava a frase "apenas para adultos" (ESTREN, 2012, p. 20).

Aos pensadores anti-establishment - de mulheres, negros e gays e toda sorte de grupos minoritários, até aqueles que simplesmente não queriam fazer parte do American way of life - foi dada completa e livre voz (BUNCHE, 2016). Quanto mais cresciam e mais radicais se tornavam, mais os artistas do underground norte-americano publicavam materiais que refletiam o mundo real, suas sensibilidades e experiências. E, enquanto a mídia estava mais preocupada com a violência retratada, a liberdade criativa experienciada por esses artistas era sem precedentes, um momento em que o ambiente era extremamente fértil e que permitiu que uma nova geração de talentos e ideias pudesse florescer.

Robert Crumb se tornou a mais reconhecida figura do underground. Seu estilo único e distintivo fez com que ele ficasse conhecido para além do movimento e do público de quadrinhos em geral. Enquanto os quadrinhos mainstream tinham os seus super-heróis cheio de questões morais e a crença na verdade, na justiça, e no jeito americano, os produzidos no underground tinham como ícones personagens como $\mathrm{Mr}$. Natural, de Crumb, e sua visão bastante ambígua do universo. Crumb também criou, em 1968, a revista que acabou se tornando o maior símbolo do underground, a Zap Comix. Apesar de não ter sido a primeira, e nem a única publicação do movimento, é considerada como aquela que marcaria o início do underground comix, além de difundilo como nenhuma outra ao publicar os trabalhos não só de Crumb, mas dos maiores quadrinistas da contracultura, como Gilbert Shelton, Rick Griffin, Spain Rodriguez, S. Clay Wilson, entre tantos outros. 
Figura 4 - Mr. Natural, um dos grandes personagens do underground

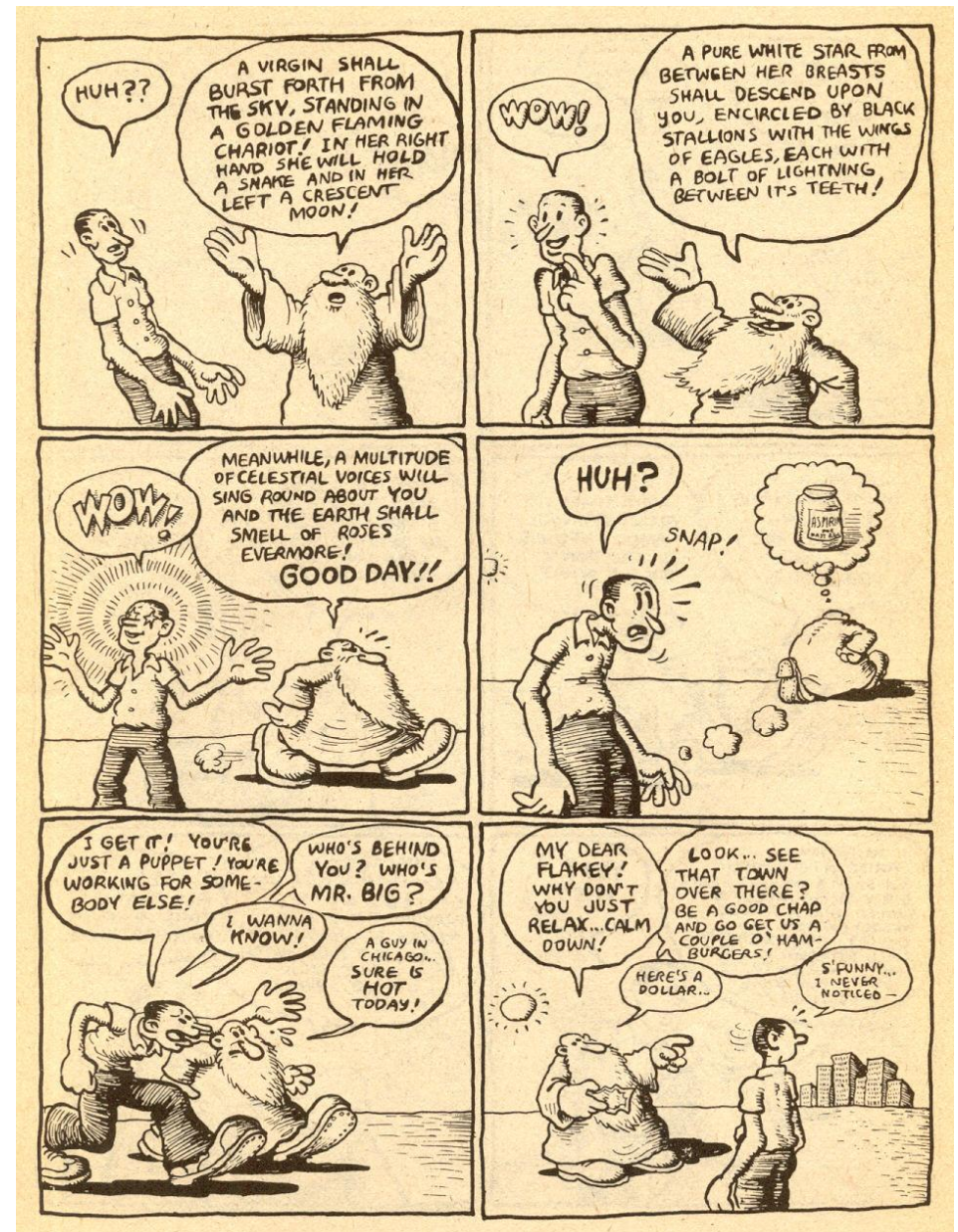

Fonte: Crumb (1971)

O sexo foi a mais imediata e aparente barreira trazida abaixo pela revolução iniciada pelos comix (BELTING, 2012, p.08). Como era estritamente proibido pela censura, o sexo nunca aparecia nas histórias de super-herói, fazendo com que o assunto fosse tratado extensivamente pelos autores do undergorund. Muitos deles, e talvez especialmente Robert Crumb, falaram sobre todos os aspectos possíveis e imagináveis relacionados ao sexo. Afinal, os quadrinhos, como linguagem, permitiam a entrega dos cenários e personagens mais loucos possíveis e impossíveis de serem reproduzidos em qualquer outro meio.

Segundo Denis Kitchen (2004), que fez parte do movimento, a marca registrada do underground continua sendo a completa liberdade artística. Entretanto, para o 
quadrinista, o maior legado deixado pelo movimento está em outra liberdade: a liberdade de direitos conquistada pelo artista. Kitchen (2004, p. 08) conta que quando começou sua carreira nos quadrinhos, as tiras, consideradas a irmã mais velha dos demais formatos, ainda eram enxergadas como uma forma de arte muito jovem, ou seja, os artistas do movimento underground fizeram parte da geração de quadrinistas que tinham noção da história de sua profissão, convivendo com seus antecessores no mesmo tempo. Inclusive, antes do surgimento e da proliferação de livros que falam dos quadrinhos, que hoje são tão comuns, estes artistas apreciavam e reconheciam os trabalhos daqueles que vieram antes deles sem precisar de alguém que lhes contasse suas histórias. Da mesma forma, ele lembra, também sabiam e conheciam o lado mais obscuro da profissão: compreendiam que os direitos autorais nos quadrinhos eram, desde sempre e quase sem exceção, propriedade das editoras ou syndicates. Desde o princípio, Kitchen (2004) afirma que todos os quadrinistas da contracultura entendiam que a antiga economia que regia o meio era inaceitável e precisava ser modificada. Ao final de seu depoimento, reforça qual foi a verdadeira revolução do underground:

A "revolução" nos quadrinhos é normalmente enxergada em termos de melhoria no âmbito dos temas cada vez mais literários, a escrita maravilhosamente idiossincrática e estilos artísticos e formatos físicos. Mas nos bastidores, uma outra revolução aconteceu, uma que dizia respeito as questões de equidade do criador, sem dúvida uma questão tão importante quanto a própria liberdade intelectual. KITCHEN, 2004, p. 09, tradução nossa ${ }^{10}$ )

$\mathrm{O}$ underground acabou representando, para seus artistas, um movimento que tinha como objetivo o fortalecimento e autonomia da produção de quadrinhos e uma forma de utilizá-lo como meio privilegiado para manifestação artística e social (VERGUEIRO, 2009, p. 20). Seus integrantes eram em sua maioria parte do espaço universitário e que se recusavam a se vender para a máquina editorial dominante, assim como buscavam burlar as regras estabelecidas pelo CCA em todo o território norteamericano. Para Bongco (2000), se desconsiderarmos muitos dos trabalhos obscenos e

\footnotetext{
${ }^{10}$ The "revolution" in comic books is most easily seen in terms of the increasingly subject matter, the wonderfully idiosyncratic writing and art styles and the physical formats. But behind the scenes another revolution took plave, one that adressed creator equity issues, arguably an issue as importante as intelectual freedom itself.
} 
violentos que beiravam o mau gosto, muito talentos preciosos surgiram dentro do underground, assim como obras icônicas e especialmente originais, levando a força artística e cultural do movimento a se espalhar pela nação.

Além disso, os comix ultrapassaram as fronteiras norte-americanas: mesmo que tenha sido um movimento que durou pouco tempo, tendo seu apogeu entre o final da década de 1960 até mais ou menos a metade da década de 1970, a influência das obras e autores dos comix, segundo Waldomiro Vergueiro (2009), foi muito além de São Francisco, atingindo países da Europa e da América Latina. No continente europeu, serviram de inspiração para revistas de vanguarda; nos países latino-americanos, acabaram por se tornar uma das facetas das vozes político-partidárias e o estilo preferido dos artistas que buscavam enfrentar os governos totalitários que tomaram o poder no continente nas décadas de 1960 e 1970 (VERGUEIRO, 2009, p. 20).

Assim, mesmo com pouco tempo de vida, os comix são considerados uma fase crucial no desenvolvimento das histórias em quadrinhos como uma forma narrativa e um meio de expressão artística. Este foi o primeiro grupo de produtores de quadrinhos significativos, nos Estados Unidos, que tinha como alvo um público completamente adulto. Inclusive, muitos dos artistas que hoje figuram na lista dos grandes quadrinistas da história, e que perceberam o grande potencial narrativo dos quadrinhos com temáticas mais profundas e sérias, vieram desse movimento; em outras palavras, a experiência de focar na capacidade dos quadrinhos de exercer diferentes tipos de influência sobre seus leitores permaneceu (BONGCO, 2000, p. 08).

Para Bongco (2000), muitos dos produtores e críticos da indústria, inclusive, concordam que as raízes dessa nova onda de quadrinhos mais realistas e densos que emergiu nos Estados Unidos nos últimos anos têm suas origens no underground. Os quadrinhos underground, dessa forma, revitalizaram o meio e demonstraram as potencialidades do mesmo, “[...] podendo-se afirmar que ajudaram na formulação de um estilo de produção de quadrinhos" (VERGUEIRO, 2009, p. 20), trazendo uma nova perspectiva sobre o que significam as histórias em quadrinhos.

O underground facilitou o processo de legitimação ao ter se tornado, nos anos seguintes, a base para o nascimento do movimento alternativo, que com todas essas características tornou-se o representante dos quadrinhos como um produto cultural hoje reconhecido não só pelos já fãs de quadrinhos, mas também pelo público em geral. 
Segundo Charles Hatfield (2005), as três principais características dos comix que o movimento alternativo herdou e que se tornaram suas bases são: os comix foram o primeiro movimento que deram nome e reconhecimento aos seus autores; apesar de também trabalharem com o formato tradicional, os quadrinhos do underground acabaram com a publicação periódica: eram produzidos esporadicamente, quando os artistas bem entendiam, já que as vendas eram baseadas não em sua periodicidade, mas na reputação de seus criadores (característica diretamente ligada à ideia de reconhecimento do autor); e, por último, os comix introduziram uma forma de produção que saía do formato da linha de produção colaborativa e deixava o autor criar sozinho e sem pressa. Em suma, os quadrinhos underground deixaram o terreno fértil para os artistas do alternativo ao transformar a autoria individual em um espaço seguro: agora, a expressão individual era a regra (HATFIELD, 2005, p. 16).

Dado tudo isso, podemos considerar os anos 1960 como a década que pavimentou o caminho para o início do processo de legitimação cultural dos quadrinhos graças a dois importantes movimentos que, apesar de possuírem raízes e propostas muito distintas, foram igualmente importantes: o intelectual europeu e o underground norte-americano. O intelectual europeu, ao conscientemente buscar a valorização dos quadrinhos como um produto cultural e artístico, permitiu que o campo recebesse novos olhares e o reconhecimento que há tanto almejava, modificando a visão de muitos sobre o meio e permitindo que o mesmo fizesse parte de discussões e adentrasse espaços nunca antes pensados; o underground norte-americano, mesmo que não almejasse o reconhecimento e valorização do meio da mesma maneira consciente, mudou o que se entendia por história em quadrinhos ao buscar inspirações em temáticas políticas e sociais, além de privilegiar estilos e formatos que nada tinham a ver com o que até então era produzido, acarretando em obras que modificariam profundamente o meio e inspirariam as gerações seguintes a buscar e valorizar sua própria criatividade. Vergueiro (2009) resume muito bem o que os dois movimentos significaram:

Com o reconhecimento do potencial artístico dos quadrinhos por parte dos intelectuais europeus e com a eclosão do movimento de quadrinhos underground estavam assentadas as bases para uma outra etapa na legitimação cultural das histórias em quadrinhos no mundo inteiro. Pode-se dizer que estava se agilizando o ritmo em que elas deixavam de ser vistas como uma linguagem exclusivamente direcionada para o público de menor idade e passavam a ser encaradas 
como manifestações voltadas a públicos diversos, com diferentes níveis de qualidade e representação do mundo. (VERGUEIRO, 2009, p. 21)

O marco inicial para a superação da disputa entre a "alta" e a "baixa" cultura, que impediu durante décadas a valorização dos quadrinhos como um produto cultural legítimo, está no movimento intelectual europeu e no underground norte-americano. Mas esse foi só o começo. Um quadrinista em especial, mesmo que à época não soubesse o estardalhaço que iria gerar, ajudou a continuar a luta pela legitimação cultural dos quadrinhos. Art Spiegelman, com suas raízes no underground e inspiração no que de melhor a Europa trouxe, modificou a visão de muitos sobre o universo dos quadrinhos ao publicar uma obra revolucionária: Maus.

\subsection{O papel de Maus na revitalização do meio}

Já na metade da década de 1970, a cena dos quadrinhos underground nos Estados Unidos começou a perder força, especialmente com a derrocada das chamadas head shops, lojas que vendiam todo tipo de parafernália ligada às drogas ilegais, especialmente a maconha e a cocaína. Com isso, os comix perderam seu principal espaço de venda e distribuição de conteúdo. Segundo Mike Kelly (2008), com a incerteza da comunidade em relação ao que era considerado obsceno ou não, dada a decisão da Suprema Corte - que reiterou, em 1973, que a obscenidade não poderia, e nem deveria, ser protegida pela primeira emenda e, por isso, a grande maioria dos quadrinhos seria considerada obscena (DUNCAN; SMITH, 2009, p. 57) -, ficou cada vez mais difícil encontrar novos espaços de venda que estivessem dispostos a comercializar este tipo de conteúdo e, para piorar, até imprimir esses quadrinhos tornouse, legalmente falando, uma tarefa perigosa. Outra motivação para a queda no interesse pelos quadrinhos underground foi que a própria audiência buscava por conteúdo cultural mais sutil. Com o fim da Guerra do Vietnã, a subcultura jovem norte-americana era mais estimulada pelo movimento contrário à guerra; os quadrinistas que, em sua

juventude, haviam começado o movimento, agora tinham que lidar com as responsabilidades da vida adulta. Até mesmo os hippies, que criaram cooperativas para 
a impressão e distribuição mais baratas dos quadrinhos, agora faziam parte de uma nova “instituição” dos quadrinhos underground (DUNCAN, SMITH, 2009, p. 58).

Esse baque do sistema de produção e distribuição dos comix acabou coincidindo com uma insatisfação cada vez maior por parte de alguns artistas. Ao mesmo tempo em que a unidade formada pelo "Verão do Amor" - ocorrido em 1967, nos Estados Unidos, e que contou com manifestações de pessoas que defendiam valores e estilos de vida alternativos, além de contrárias à Guerra do Vietnã -, começava a esmaecer, a cena underground também começou a se diluir e a criar grupos separados que focavam em seus próprios interesses: gênero, raça, sexualidade e classe (KELLY, 2008, p. 316). Com isso, cada vez mais iam diminuindo os artistas que ainda enfocavam no sexo e no uso de drogas como temática, enquanto um grupo crescente de artistas com outros tipos de inspiração passava a reivindicar espaço com um padrão mais alto, buscando um novo direcionamento para os comix. Com isso, os quadrinhos alternativos, com suas raízes no movimento underground (HATFIELD, 2005, ix), passaram a ganhar destaque no universo dos quadrinhos estadunidenses.

Os quadrinhos alternativos são normalmente criados por um único quadrinista e a história envolve uma visão muito pessoal do artista. Muitos são autobiográficos e o foco fica mais no autor do que nos personagens. O quadrinista normalmente publica seu próprio trabalho e o mesmo consiste em resistir aos gêneros do mainstream ou satirizalos, ao mesmo tempo em que busca valorizar suas raízes no underground. A variedade de histórias em quadrinhos que começou a surgir dentro desse novo movimento encontrou uma nova audiência, diferente daquela que havia apoiado o underground, inclusive pela mudança na distribuição e venda desses novos quadrinhos alternativos, que passaram a ser comercializados no mesmo espaço que os mainstream, em um novo tipo de estabelecimento, as comic book shops (DUNCAN; SMITH, 2009, p. 67). Não obstante, o próprio mainstream foi afetado por todas essas mudanças, buscando inovações nos formatos e especialmente nos vieses criativos da indústria. As grandes editoras, especialmente a Marvel e a $D C$, resolveram fugir de suas já conhecidas fórmulas e correr atrás de elementos narrativos e gráficos que seguiam o caminho oposto do que até então haviam produzido.

Assim, os anos 1980 ficaram marcados pela aparição de novas produções que passaram a privilegiar o público adulto, tanto no espaço alternativo quanto no 
mainstream. Histórias mais densas, com temáticas mais profundas e menos "coloridas" do que aquelas apresentadas ao público até então começaram a invadir o mercado de quadrinhos norte-americano. Até mesmo personagens já conhecidos do grande público leitor de quadrinho ganharam uma roupagem mais intrincada, assim como personalidades mais problemáticas e complexas, a fim de manter o público jovem que agora cresceu e que buscava algo além das antigas histórias. Algumas dessas obras, inclusive, transformaram-se nas "obras primas" de muitos de seus autores. É neste espaço no qual o quadrinista que ajudou a renovar o meio floresce: Art Spiegelman.

Art Spiegelman nasceu em 1948, em Estocolmo, na Suécia. Seus pais, sobreviventes dos campos de concentração de Auschwitz durante a Segunda Guerra Mundial, imigraram para os Estados Unidos com o filho ainda pequeno. Considerado um dos mais importantes quadrinistas da vanguarda norte-americana, recebeu em 1992 o Prêmio Pulitzer - o mais importante do mercado editorial norte-americano -, em uma categoria especial, por sua visão singular diante da tragédia vivida por seus pais durante o Holocausto. Em sua autobiografia, intitulada Breakdowns: retrato do artista quando jovem, Spiegelman (2009) nos conta um pouco de sua história e nos ajuda a entender como Maus, obra que acreditamos ter papel fundamental na revitalização do meio, se tornou uma realidade. Inclusive, o confuso primeiro subtítulo dessa autobiografia lançada originalmente em 1978 - Breakdowns: de Maus até hoje.Uma antologia de histórias de Art Spiegelman, é uma referência à tira de três páginas que idealizou em 1972 (trabalho mais antigo da seleção de Breakdowns), que inspiraria o trabalho que nasceria anos depois e que o tornaria reconhecido ao redor do mundo. 
Figura 5 - Capa original de Breakdowns, autobiografia de Spiegelman

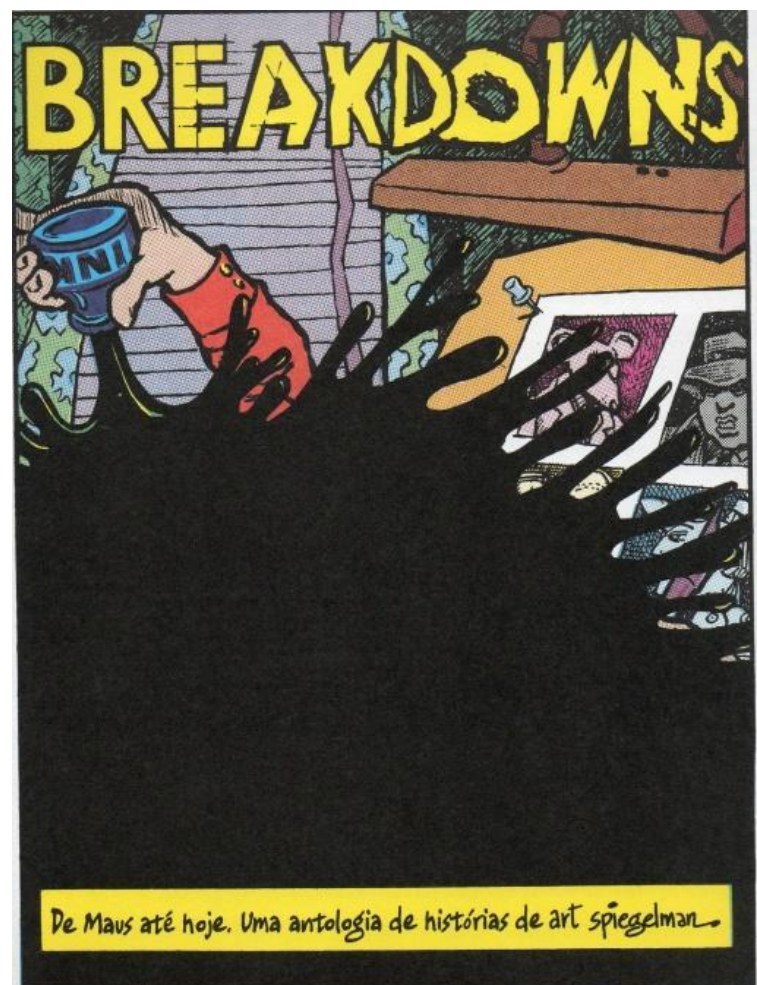

Fonte: Spiegelman (2009)

Dentro da casa de seus pais imigrantes, os quadrinhos eram sua única janela de acesso à cultura americana, lendo, desde muito novo, Pato Donald de Carl Banks, Luluzinha de Jonh Stanley, e a revista Mad de Harvey Kurtzman, talvez sua maior influência. Percebeu, dessa maneira, que queria fazer parte desse grupo de artistas e, desde então, a única coisa que mudou com o passar do tempo foi o tipo de quadrinhos que queria fazer. No colegial, entre uma aula e outra, começou a fazer quadrinhos estranhos, que não se encaixavam na arte comercial e, em 1965, levou alguns deles para a revista recém-lançada East Village Other, já que, como nas primeiras edições os quadrinhos não eram de alto nível, teve certeza de que seu trabalho se encaixaria perfeitamente nessas condições (SPIEGELMAN, 2009). 
Figura 6 - Trabalho de Spiegelman na capa da revista The East Village Other, considerada um dos primeiros semanários underground e que ajudou a definir o que hoje é conhecido como anos 60.

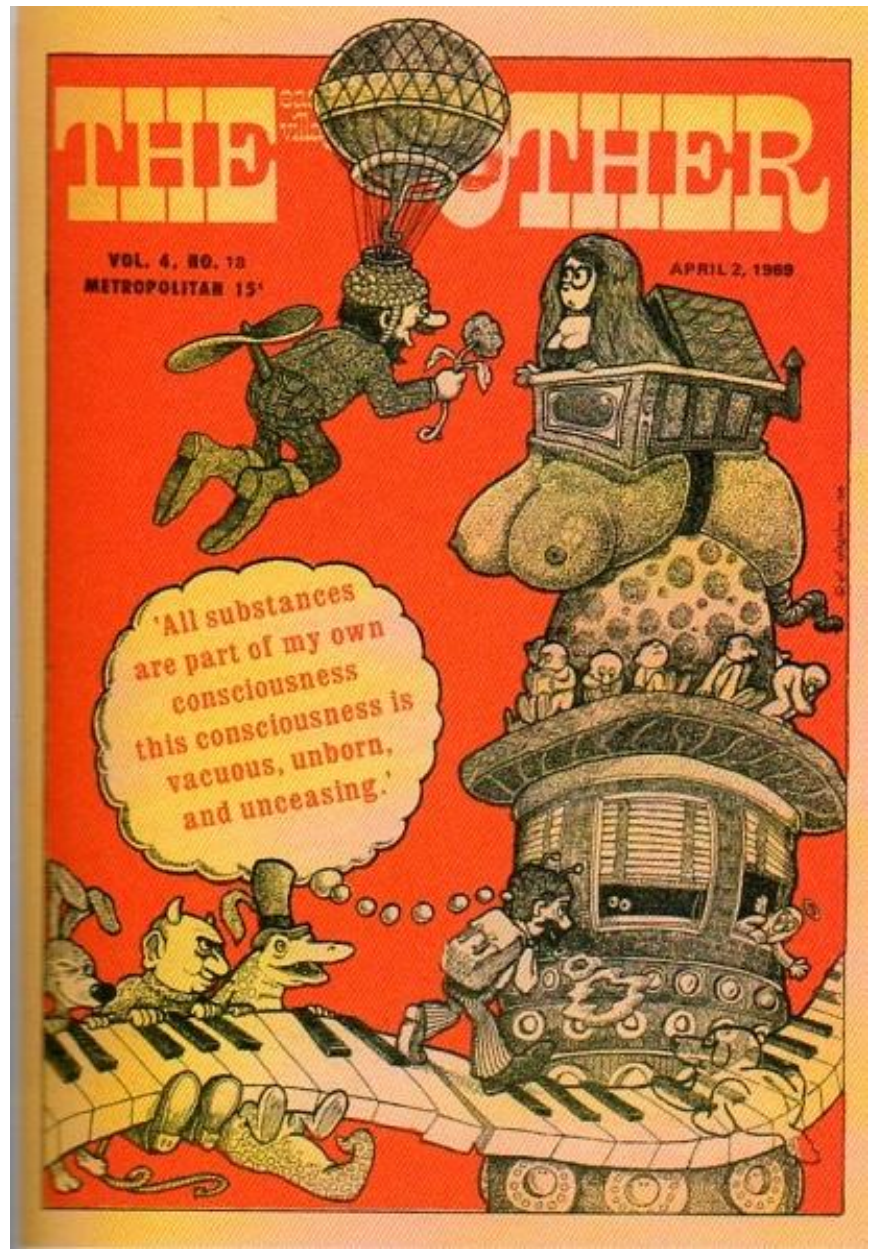

Fonte: Spiegelman (2009)

"Por volta de 1967, minha virgindade e minha mente já tinham ido embora fazia tempo[...]" (SPIEGELMAN, 2009) e, nos raros momentos de lucidez que ainda tinha, desenhava folhetos impressos - que exaltavam o efeito do LSD em seu corpo e que protestavam contra a guerra do Vietnã - e os distribuía em esquinas e parques; muitas vezes não possuíam nenhuma mensagem reconhecível. No mesmo ano, antes mesmo dos quadrinhos serem definidos como underground, conheceu Robert Crumb, que lhe mostrou algumas páginas que havia acabado de fazer sob o efeito do LSD. De acordo com Spiegelman (2009), o trabalho de Crumb era uma paródia dos cartuns populares da época - flexíveis, complicados e intricados -, em um momento em que os quadrinhos ainda tinham uma pretensão ao minimalismo (SPIEGELMAN, 2009). 
Sua experiência com drogas psicotrópicas fez com que seus "quadrinhos esquisitos" ficassem em segundo plano, e por isso decidiu passar essa responsabilidade para as mãos habilidosas de Crumb, enquanto perseguia a "iluminação" sem nenhum compromisso. (SPIEGELMAN, 2009) Nos anos seguintes, quando decidiu finalmente colocar os pés no chão, tentou absorver tudo o que Crumb e outros quadrinistas underground faziam, imitando-os descaradamente, o que resultou em trabalhos constrangedores, com tentativas medíocres de repetir o humor transgressivo e a literatura erótica desses artistas, assim como uma experiência grotesca que visava quebrar tabus e que incluía necrofilia, parricídio e outras formas de violência. Spiegelman conta que

Uma dessas tirinhas culminava quando um personagem meu, o Víbora, trepava com o pescoço da cabeça cortada de um menininho. $\mathrm{Eu}$ queria desenhar as imagens mais perturbadoras que podia imaginar, e, no fim, elas ao menos perturbaram Dana, a esposa de Crumb, o suficiente para que ela proibisse minhas visitas à casa deles. Eu era um membro jovem e ousado de uma cena estimulante, mas, rapaz, eu estava perdido. (SPIEGELMAN, 2009)

Quando os anos 1970 substituíram os anos 1960, Spiegelman (2009) conta que achou um caminho com a ajuda de encontros significativos. O ano de 1969 foi muito agitado e incluiu um colapso e uma internação em um hospital psiquiátrico, sua expulsão da faculdade, o suicídio de sua mãe no ano anterior e uma tentativa - por mais que desastrosa - de viver em uma comunidade. Entretanto, foi o ano em que conheceu Ken Jacobs, cineasta de vanguarda e professor de cinema na Universidade de Binghamton, em Nova York, que se entusiasmou com um de seus trabalhos de história da arte sobre Master Race, de Bernard Krigstein. Jacobs se tornou seu tutor e lhe ensinou o valor da arte "sem balõezinhos de diálogo" (SPIEGELMAN, 2009). Ao se mudar para São Francisco, em 1970, conheceu Bill Griffith, que se tornou seu melhor amigo e futuro parceiro em projetos como Short Order Comix.

Em 1971, conheceu Justin Green, que à época desenhava a obra-prima que inauguraria um novo gênero nos quadrinhos: a autobiografia confessional, com Binky Brown Meets the Holy Virgin Mary. Diferentemente de Robert Crumb, que traduzia suas obsessões pessoais em uma linguagem "cartunesca universal" (SPIEGELMAN, 
2009), Green usava a culpa psicossexual e católica de sua vida como principal assunto a ser esmiuçado em suas obras. Foi assim que Spiegelman encontrou a sua própria psique e descobriu que deveria, em vez de desenhar a violência mais chocante que podia imaginar, identificar as atrocidades do mundo real ao qual seus pais haviam sobrevivido e no qual ele havia sido criado.

Figura 7 - Extrato de Binky Brown Meets the Holy Virgin Mary, de Justin Green

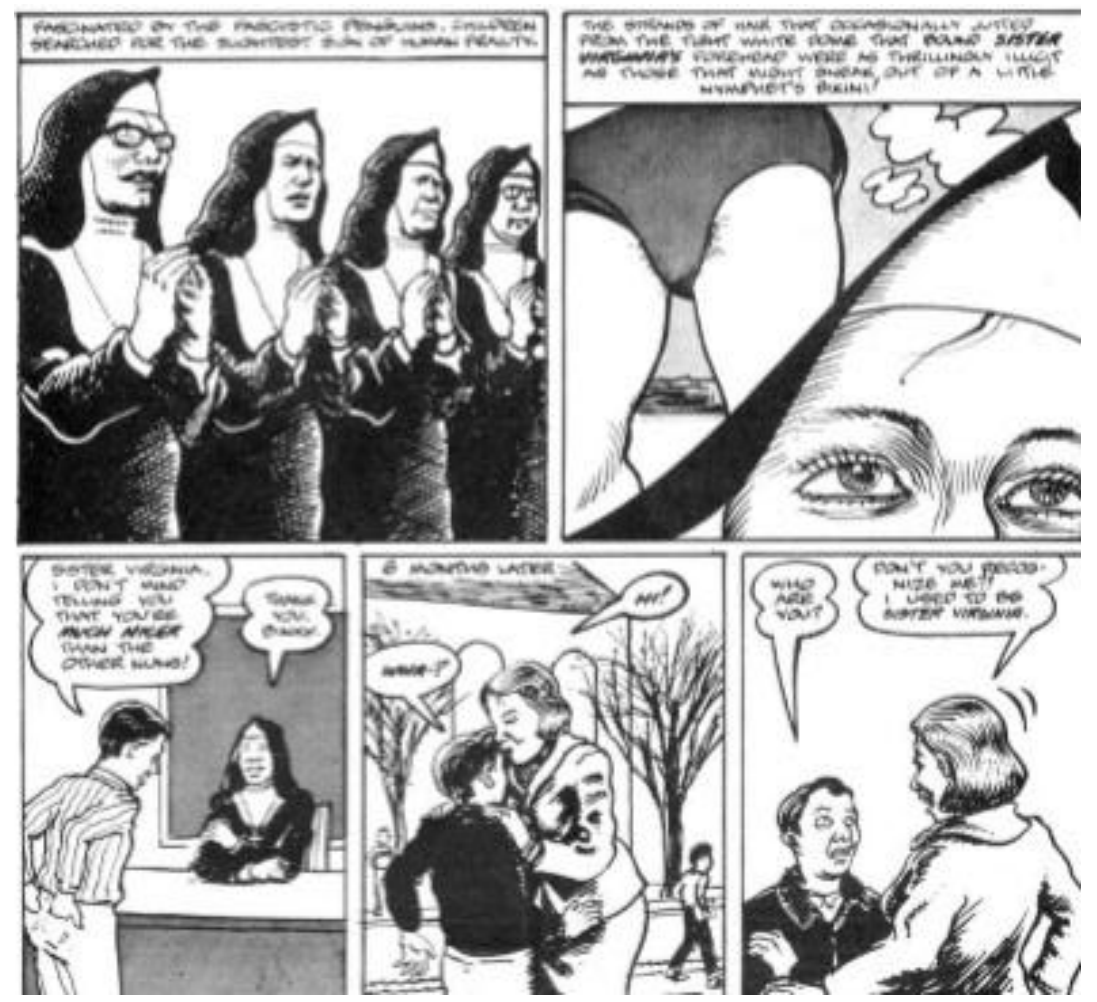

Fonte: Green (1972)

Por conta disso, seus interesses começaram a divergir da cena dominante do underground, ainda voltada ao sexo, às drogas e às histórias transgressivas do gênero e voltaram-se para o descobrimento do que era preciso para que os quadrinhos "narrativos" se tornassem quadrinhos (SPIEGELMAN, 2009). Spiegelman, assim, ajudou a formatar o que viriam a ser os quadrinhos alternativos. Inclusive, uma das revistas que fez a transição entre os quadrinhos underground e os alternativos foi a revista Arcade, criada por Spiegelman em parceria com Bill Griffith. Apesar de ter 
durado pouco tempo, contando com apenas sete edições entre 1975 e 1976, trouxe trabalhos de grandes artistas do underground para uma geração de leitores que era muito nova para ter apreciado o movimento em sua glória.

Figura 8 - Capa da edição \#7 da Arcade, que trouxe trabalhos de Robert Crumb, Harvey Kurtzman, Spain Rodriguez, S. Clay Wilson, entre outros quadrinistas do underground

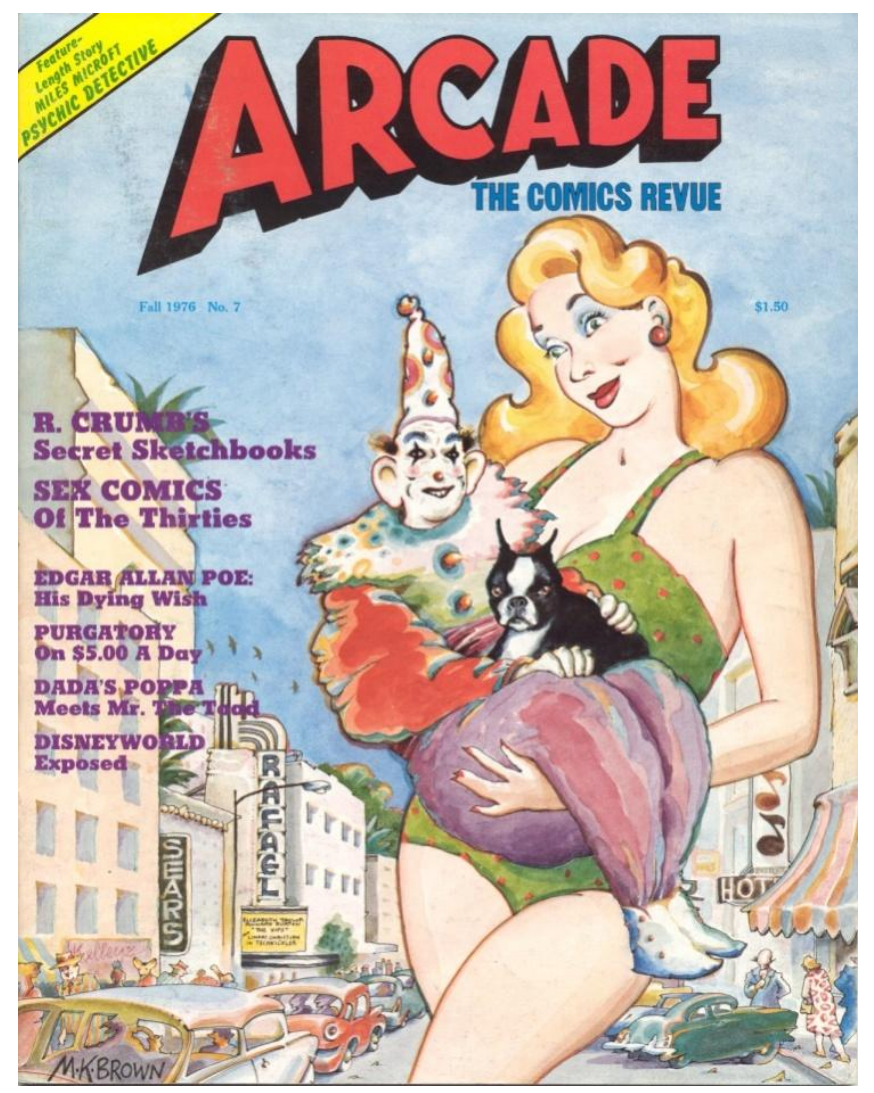

Fonte: Spiegelman; Grffith (1976)

Segundo Duncan e Smith (2009, p. 67), apesar do fracasso da publicação, inclusive com Spiegelman afirmando que nunca mais trabalharia na produção de outra revista, ao conhecer sua futura esposa, Françoise Mouly, resolveu fazer uma coletânea de quadrinhos que deu origem a outra publicação, a Raw. Lançada em 1981, mostrava o trabalho dos quadrinistas independentes e fez sucesso muito rápido, com leitores e até mesmo artistas querendo contribuir e insistentemente perguntando quando a próxima edição seria lançada. A publicação contava não só com os já reconhecidos quadrinistas do underground, como também artistas alternativos que estavam começando. Contudo, 
a contribuição mais significativa desse importante marco na história das histórias em quadrinhos foi do próprio Spiegelman, que publicaria a primeira - e pequena - versão de Maus, desenhada de maneira mais sóbria do que seus primeiros trabalhos, mas mais radical no conteúdo.

Figura 9 - A primeira versão de Maus, de 1972, publicada na revista Raw

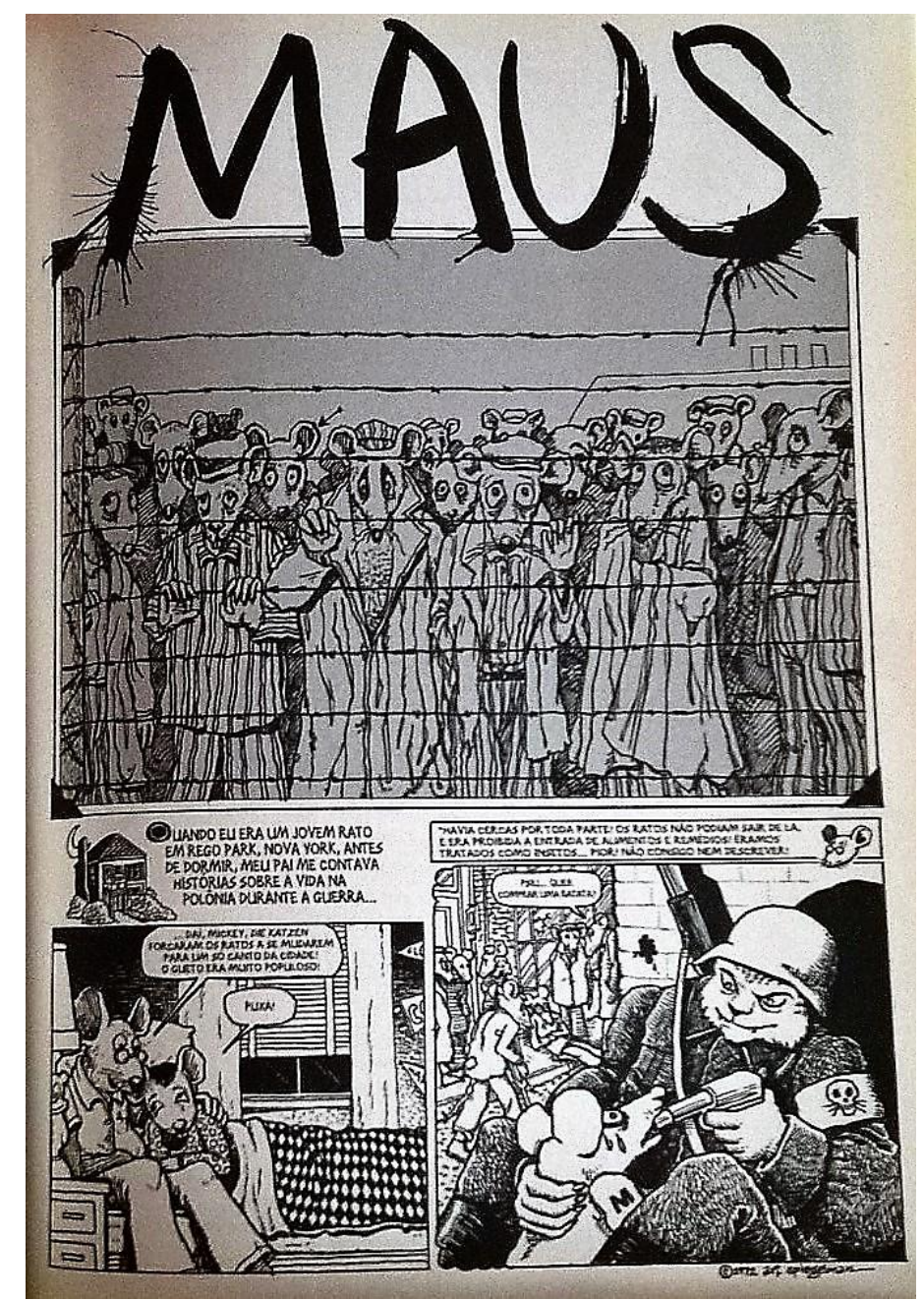

Fonte: Spiegelman (2009)

Entretanto, um ano em particular se destaca: 1986 foi o ano, como nenhum outro, que trouxe obras que marcariam e modificariam o que se compreendia por quadrinhos até então, com trabalhos mais politizados e recheados de crítica política e social. Dentre estas obras, está a "tríade" de 1986: Batman: o cavaleiro das trevas, de Frank Miller; Watchmen, de Alan Moore e Dave Gibbons, e Maus, de Art Spiegelman. 
As duas primeiras, ambas lançadas pela DC Comics, uma editora do mainstream, se tornaram dois dos maiores clássicos de todos os tempos ao desconstruírem o conceito do super-herói, trazendo-os para uma "Era de Trevas", era essa mais realista e muito mais sombria. Entretanto, foi Maus - agora sim o livro - de Art Spiegelman, que mais radicalmente transformaria o meio.

Spiegelman foi sem dúvida influenciado e moldado pela cena underground, que o levou à comunidade artística em que viveu e trabalhou a partir do final da década de 1970. A importante ruptura nos modelos técnicos e temáticos iniciados no underground permitiu a Spiegelman experimentar visual e narrativamente, o que acarretou, segundo Mike Kelly (2008, p. 335), no que talvez seja o evento mais significativo na história dos comix: a publicação da primeira edição de Maus, em 1986, pela Pantheon Books . O resultado de tal publicação, especialmente depois do Pulitzer concedido a Spiegelman, teve um profundo impacto no universo editorial das histórias em quadrinhos, assegurando o estabelecimento do movimento alternativo nos Estados Unidos.

Art Spiegelman (2005) desenvolveu e serializou Maus entre 1980 e 1991 e a história parte das entrevistas que Spiegelman conduziu com o pai em 1978, no bairro de Rego Park, em Nova York. Maus: a história de um sobrevivente, a história completa, tem suas raízes na tira de três páginas de 1972 e que o motivou a desenterrar a biografia de seu pai, Vladek, um judeu nascido na Polônia que narra a traumática experiência que viveu nos campos de concentração nazistas e como sobreviveu ao Holocausto. A história se divide em duas linhas temporais: o passado, que refaz toda a trajetória de Vladek e sua esposa, Anja, desde a juventude tranquila até o aprisionamento nos campos e posterior libertação com o fim da Segunda Guerra Mundial, e o tempo presente, ou seja, quando Spiegelman inicia a entrevista com o pai a fim de recolher material para seu projeto. Este tempo presente, inclusive, gira em torno do delicado e conturbado relacionamento entre pai e filho, além do "fantasma" da mãe de Art, que cometera suicídio há pouco tempo e que assombrava a vida de ambos.

O que mais chama a atenção na obra, entretanto, é a forma como o quadrinista retrata os principais atores do Holocausto: os judeus são retratados como ratos, os nazistas como gatos, os poloneses como porcos e os americanos como cachorros, todos de forma antropomórfica. Inclusive, uma análise da obra e do uso da antropomorfia nos 
personagens de Maus pode ser encontrada em outro trabalho da autora (CARVALHO, 2015).

Figura 10: A primeira cena de Maus e nosso primeiro contato com Vladek

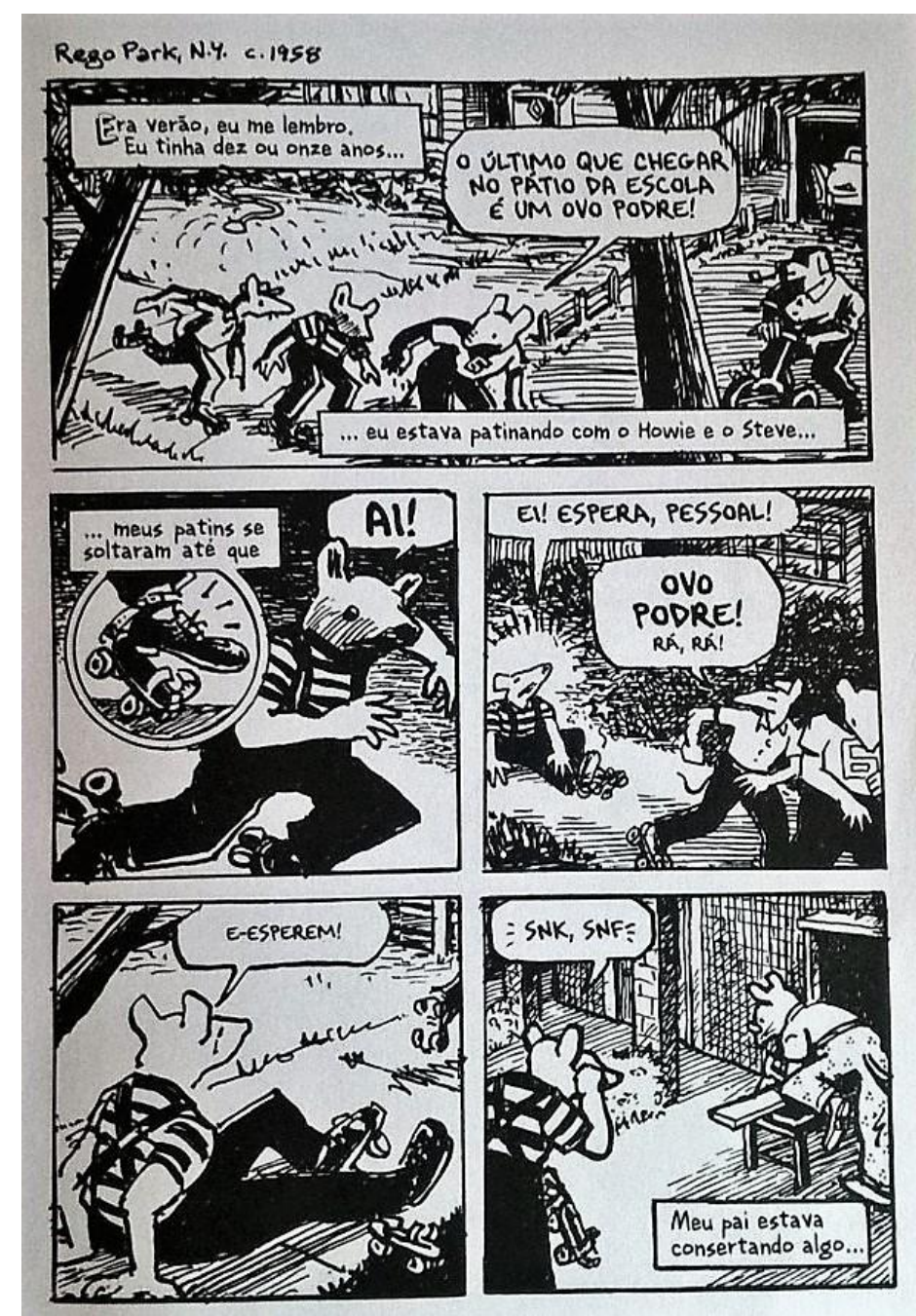

Fonte: Spiegelman (2005, p. 05)

Uma coleção dos primeiros seis capítulos da série foi colocada nas prateleiras em 1986, dando ao livro a atenção não só do mundo dos quadrinhos alternativos e underground, mas também do mainstream e do público leitor em geral. O segundo volume, com o restante dos capítulos, foi lançado em 1991. Maus já foi rotulado como várias coisas: da biografia à historiografia, passando por graphic novel, jornalismo em quadrinhos e até como uma “etnografia pós-moderna” (BRANDT, 2014, p. 70). Independentemente da classificação que receba, Maus acabou representando uma reviravolta para o campo dos quadrinhos e importante instrumento no processo de 
legitimação cultural do mesmo ao se tornar uma das primeiras histórias em quadrinhos a receber significativa atenção positiva da mídia, academia e público em geral em nível mundial.

O título de um dos textos de Bart Beaty (2012) no livro Comics versus Art já consegue sugerir, e até confirmar, a importância de Maus para o processo de legitimação cultural das histórias em quadrinhos: Academe discovers the comic world: the canonization of Art Spiegelman's Maus (BEATY, 2012, p. 117) o que, traduzindo, seria algo como "A academia descobre o universo dos quadrinhos: a canonização de Maus, de Art Spiegelman". Isso, porque segundo o autor, Maus pode ser considerada a obra dos quadrinhos mais celebrada já publicada nos Estados Unidos, quiçá no mundo, não só pelo conteúdo, mas pelos prêmios que recebeu. Inclusive, a tão discutida e muitas vezes duramente criticada escolha do uso da antropomorfia nos personagens serviu como uma ferramenta de marketing, colocando a obra em um patamar único dentro das narrativas sobre o Holocausto, assim como a seriedade do tema colocou o trabalho em um espaço nunca antes enxergado do campo dos quadrinhos (BEATY, 2012, p. 117).

Maus pode ser considerado como um dos quadrinhos responsáveis, em grande parte, pela nova onda de interesse pelos quadrinhos, nos Estados Unidos, na segunda metade da década de 1990 (BONGCO, 200, p. 11). Isso, porque a obra causou um imenso burburinho já no ano seguinte de sua publicação, quando foi nomeada para o prêmio de biografia no National Book Critics Circle, em 1987. Contudo, foi em 1992 que a obra de Spiegelman chamou mais atenção: Maus ganhou o Pulizter Prize Special Awards and Citations, prêmio especial do Pulitzer - concedido desde 1917 e considerado um dos mais importantes prêmios do circuito jornalístico-literário norteamericano - que foi outorgado pela primeira vez a um quadrinista.

Por conta de tudo isso, o sucesso de Maus foi uma surpresa para muitas pessoas. Ficou claro, com a repercussão e atenção que recebeu, que os leitores norte-americanos ficaram impressionado com o tema, o estilo, o formato e o tamanho (publicada originalmente em duas partes e, depois, compilada em uma) da obra de Spiegelman. $\mathrm{Na}$ verdade, a surpresa veio exatamente pelo fato de Maus ser uma história em quadrinhos: até então, era inimaginável, seja para o público, para a crítica e até para alguns quadrinistas, que "o trauma central do século XX" (PONTES, 2007) pudesse ser 
contado em uma mídia como os quadrinhos e, mais ainda, que fosse realizado em tal grau de excelência. O próprio Spiegelman confirma essa ideia ao dizer: "não fui considerado um artista de quadrinhos porque fiz algo que ganhou um Pulitzer" (SPIEGELMAN apud BEATY, 2012, p. 101, tradução nossa ${ }^{11}$ ).

Apesar da inovação temática e estilística de Spiegelman à época, ele não pode ser considerado o único artista a mostrar novas possibilidades para as histórias em quadrinhos. Existem muitas outras tentativas de sucesso nos quadrinhos que desfragmentaram as velhas fórmulas e maximizaram a riqueza e temática do meio. Aliás, como é sempre importante ressaltar, muitos desses trabalhos inovadores se deram na Europa, especialmente na Bélgica, França, Itália e Alemanha, países em que a tradição de histórias em quadrinhos bem roteirizadas e habilidosamente desenhadas para adultos ocorre, como vimos na sessão anterior, desde a década de 1960. Nos Estados Unidos, onde os quadrinhos tinham como seu principal alvo o público infanto-juvenil, grandes mudanças ocorreram no campo nas últimas três décadas, como evidenciado por obras de quadrinistas como Will Eisner e Harvey Pekar sem esquecer, é claro, de Alan Moore e Frank Miller e suas obras Watchmen e Batman - o cavaleiro das trevas que, também lançados em 1986, causaram uma mudança de percepção e relacionamento do público com os quadrinhos, não só em relação à temática, mas também em relação aos eventos nos âmbitos da produção e distribuição.

Entretanto, para a maioria do público - e aí estão inclusos os já fãs-leitores de quadrinhos e o público não-leitor de quadrinhos - o fenômeno mais importante de reavaliação das histórias em quadrinhos foi mesmo a publicação de Maus e a resposta do público e da crítica em relação à obra (GORDON, 2010, p. 179). Ian Gordon (2010) lembra que Joseph Witek "profetizou”, ainda em 1989, que Maus já havia mudado a percepção cultural em relação ao que os quadrinhos podem ser e o que seus autores podem realizar ao levar a sério a mídia da arte sequencial. Dessa forma, enquanto Watchmen e Batman: O cavaleiro das trevas reinventaram o que se entendia por quadrinhos de super-heróis para os já fãs do meio, Maus reinventou o meio para os não leitores. Aliás, o próprio título do texto de Gordon já reflete como o autor percebe a obra e sua importância: Making Comics Respectable: How Maus Helped Redefine a

\footnotetext{
${ }^{11}$ I've been designated not as comic book artist because I did something that got a Pulitzer.
} 
Medium, ou, em tradução literal, "Tornando os quadrinhos respeitáveis: como Maus ajudou a redefinir um meio".

Isso tudo ocorreu porque Maus, segundo Andrew Loman (2010), foi a obra que mais ousadamente se afastou das percepções comuns que se tinha sobre os quadrinhos: mesmo que alguns possam dizer que suas técnicas estéticas não sejam tão distantes das de outros trabalhos, ainda assim o seu afastamento dos demais gêneros dos quadrinhos da época foi muito mais completo do que as duas outras obras. Por conta disso, acabou sendo considerado por muitos como a maior façanha dos quadrinhos até então (LOMAN, 2010, p. 211).

Figura 11 - Um pequeno exemplo do por que o tema, o estilo, a técnica e a coragem fizeram de Maus uma obra sem precedentes.

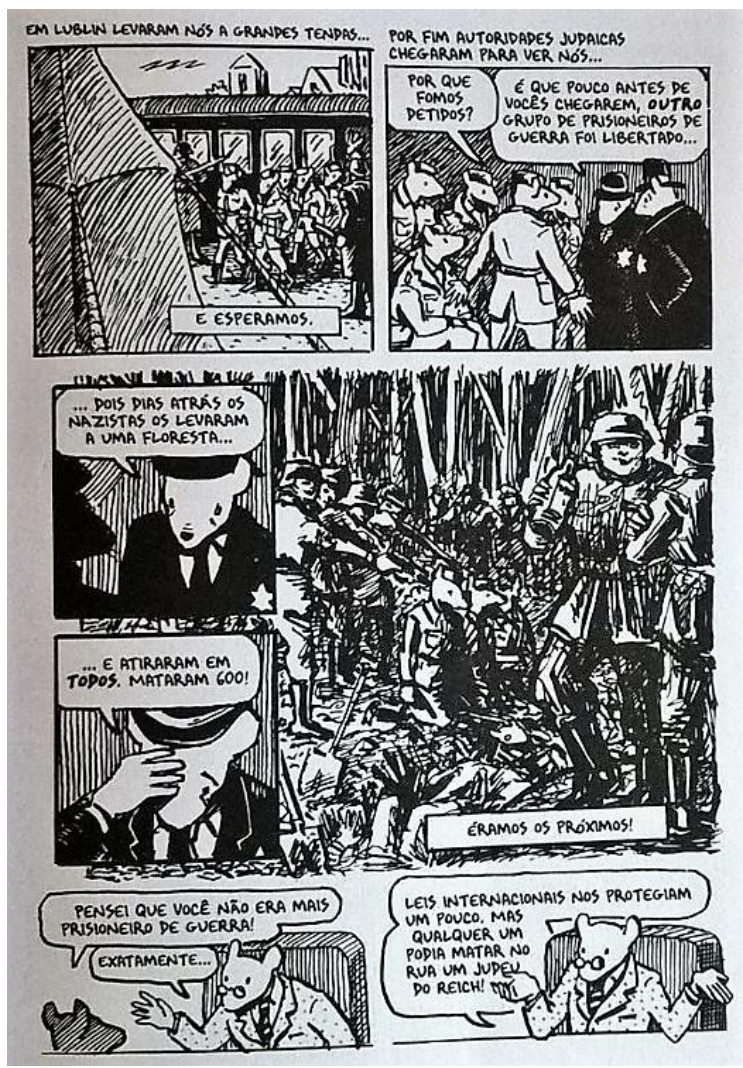

Fonte: Spiegelman (2005, p. 63)

A consequência de tudo isso é que Spiegelman e sua obra passaram a figurar em importantes publicações de diferentes extratos culturais. Antologias como a Postmodern 
American Fiction: A Norton Anthology e a The Norton Anthology of American Literature, ambas da W.W. Norton e consideradas importantes no circuito norteamericano, trouxeram a história de Vladek para suas páginas. Fazer parte dessas antologias, lembra Loman (2010), significa dizer que o trabalho é ótimo e que atingiu um alto status. Outra coisa que demonstra como Maus modificou a percepção de muitos foi que textos acadêmicos sobre a obra começaram a aparecer em 1992, apenas um ano após a publicação do seu segundo volume, algo sem precedentes. A atenção recebida por Maus mostra a sua força: em contraste com as demais obras consideradas importantes e relevantes na época, estas nem sequer chegaram perto do número de textos escritos em relação a obra de Spiegelman. Um exemplo disso é que a $M L A$ Bibliography contou 60 textos publicados sobre a obra entre 2006 e 2008. Mesmo quadrinhos que receberam consideração da crítica e da academia depois de Maus, como Persepolis, jamais alcançaram o que Maus alcançou (LOMAN, 2010, p. 217).

Aliás, Gordon (2010) afirma que uma maneira rápida e eficiente de saber o real impacto de Maus é a de procurar sobre o livro em bancos de dados, como o Lexis. Por exemplo, de 1986, ano da publicação, até 1999, o livro havia recebido 772 citações. Na década seguinte, até 2007, foram 2.053 acessos. Aliás, um teste mais simples pode demonstrar a força de Maus no espaço acadêmico: se digitarmos na página do "Google Acadêmico"12 as palavras "Maus+Art+Spiegelman" teremos 6.850 resultados, mais do que os resultados somados de duas das mais importantes publicações das últimas décadas: Persepolis, de Marjane Satrapi (2.660 resultados) e Watchmen (3.660 resultados). Destarte, o livro cresce a cada dia em reputação, o que faz com que qualquer menção às grandes obras dos quadrinhos não esteja completa se a obra de Spiegelman não for citada como uma das mais importantes e pioneiras (GORDON, 2010, p. 185).

Por ter sido publicada na Raw anos antes de ser publicada para o consumo do público em geral, Maus já era alvo de discussões entre os fãs dos quadrinhos muito antes das críticas jornalísticas e ensaios acadêmicos. Entretanto, são exatamente nestes espaços que podemos notar como a obra de Spiegelman foi impactante e como ajudou a ressignificar, para o público e para a crítica, as potencialidades do campo para além da perspectiva comum perpetrada durante anos. Um exemplo é a presença maciça de Maus

\footnotetext{
${ }^{12}$ scholar.google.com.br/. Acesso em: 04 dez. 2016.
} 
como temática de críticas e artigos nas páginas do The Comics Journal, importante revista voltada à publicação de notícias, entrevistas e críticas sobre os quadrinhos e que, além do mais, sempre defendeu a maior valorização cultural do meio. A revista Raw, por exemplo, foi considerada por muitos que contribuíram para as páginas do The Comics Journal como uma das publicações sobre a arte dos quadrinhos mais importantes da era e que tinha como idealizador uma força criativa sem igual (BEATY, 2012, p. 118). O debate feito em cima dos méritos de Maus no The Comics Journal, assim, foi crucial para o desenvolvimento da orientação estética da revista e, consequentemente, modificou o olhar dos interessados.

Dale Luciano (apud BEATY, 2012) escreveu o terceiro trabalho sobre Maus publicado no The Comics Journal. Transcrito abaixo, o comentário de Luciano deixa claro que esta não é apenas uma avaliação da obra em particular, mas da natureza e história do campo dos quadrinhos até aquele momento, além de uma declaração escancarada das aspirações esperadas para o campo escrita pelo próprio editor da revista:

\begin{abstract}
Maus, de Art Spiegelman, encontra-se entre as mais notáveis conquistas em quadrinhos. É um livro que redefine o cerne dos limites dos quadrinhos como um meio; a realização de seu criador das possibilidades implícitas na narrativa gráfica é sem igual. É um trabalho que será lembrado e discutido por anos, um evento sem precedentes que pode determinar como os avanços do meio serão medidos (LUCIANO apud BEATY, 2012, p. 119, tradução nossa ${ }^{13}$ ).
\end{abstract}

Ao final do texto, Luciano ainda chega a considerar Maus como uma vingança dos quadrinhos como um todo: para ele, depois da publicação da obra, ninguém mais poderia dizer que um meio como os quadrinhos não pode ser usado, ou não tem o que é necessário, para retratar a complexidade e delicadeza da emoção humana (BEATY, 2012, p. 119).

\footnotetext{
${ }^{13}$ Art Spiegelman's Maus is among the remarkable achievements in comics. It is a book that redefines the hitherto boundaries of the comics medium; its creator's realization of the possibilities implicit in the graphic storytelling form is uncompromised. It is a work that will be recollected and argued about for years, a watershed event against witch future advances in the medium will be measures.
} 
Segundo Miles Orvell (1992), o que faz com que Maus seja tão significativo é o fato de que ele adota um tema que até então ia contra a maré dos estilos das histórias em quadrinhos, buscando uma narrativa que fique entre o político e o pessoal e que estabeleça uma postura única diante do trauma que foi o Holocausto. Ao transferir os quadrinhos para um campo com questões políticas e psicológicas sérias, Spiegelman ofereceu um tipo de obra que ultrapassou as barreiras do público comum dos quadrinhos norte-americanos, que normalmente tinha seu apetite pautado em histórias de superheróis e sua extravagante luta contra o crime. Por fazer parte de um movimento tão satiricamente crítico da cultura contemporânea - especialmente a estadunidense - criou um novo público leitor para as histórias em quadrinhos.

Além disso, lembra Andreas Huyssen (2000), apesar de se ter uma noção geral de que, politicamente, o genocídio dos judeus deveria ser lembrado pelo maior número de pessoas, o uso de um meio de massa nunca foi considerado como próprio ou correto. Todavia, Maus fez com que nos aproximássemos da memória do Holocausto e suas representações de uma maneira tão completamente diferente e delicada que uma reavaliação sobre os quadrinhos e a cultura de massa foi possível; isso, porque "Spiegelman entra em um embate com a inautenticidade de representação dentro do gênero da cultura de massa ao mesmo tempo em que conta a história de maneira autobiográfica e alcançando um poderoso efeito de autenticidade”. (HUYSSEN, 2000, p. 81 , tradução nossa ${ }^{14}$ )

Maus é, assim, a história em quadrinhos que conseguiu modificar mais profundamente a aceitação do público e da crítica em relação ao valor cultural do meio ao receber um prêmio considerado como legítimo dentro do campo da produção cultural, abrindo assim as portas para uma nova era dos quadrinhos. Após a publicação dos dois volumes de Maus, a mídia norte-americana e mundial ficou impressionada com o fato de que os quadrinhos tinham tanto potencial para a sofisticação intelectual e artística. Por conta disso, segundo Andrew Loman (2010), durante os anos 1990 Spiegelman acabou se tornando uma espécie de embaixador do meio, escrevendo sobre o mesmo em revistas de prestígio, como a The New Yorker. Por isso, mesmo que

\footnotetext{
${ }^{14}$ Spiegelman confronts the inauthenticity of representation within a mass cultural genre while at the same time telling an autobiographic story and achieving a powerful effect of authentication.
} 
saibamos que ele não é o único responsável por essa nova visão dos quadrinhos, ele pode sim ser considerado o mais importante para o período.

Após a publicação e prêmio Pulitzer de Maus, juntamente com a invasão do mangá em solo estadunidense e o aumento nas publicações das graphic novels, as portas do mercado norte-americano de quadrinhos se abriram para um novo universo e compreenderam o potencial de um meio que não precisava mais estar vinculado aos gêneros tradicionais - super-heróis, policial, de aventuras, etc - para fazer sucesso. Assim, novas expectativas para o campo foram desenvolvidas e novas premissas foram cristalizadas. Mais além, Maus derrubou os preconceitos existentes de que as histórias em quadrinhos não poderiam retratar períodos históricos problemáticos, como foi o caso da Segunda Guerra Mundial (VERGUEIRO, 2009, p. 30). O reconhecimento obtido por Spiegelman trouxe olhares de um público diferente daquele das histórias em

quadrinhos, de um público mais geral. É possível afirmar, inclusive, que os produtos da Nona Arte passaram a ter um novo tipo de recepção, tendo em vista que “[...] o cabedal social das histórias em quadrinhos foi objeto de forte valorização [...]” (VERGUEIRO, 2009, p. 30-31). E aí está incluída a classificação que Maus recebeu e pelo qual é reconhecida até hoje: a de graphic novel.

\subsection{A chegada das graphic novels ao mercado}

Depois do Pulitzer de Maus, de Art Spiegelman, os quadrinhos alternativos passaram a ser vistos como o grande símbolo das mudanças pelas quais as histórias em quadrinhos estavam passando. O campo, então, ganhou um grau de respeitabilidade jamais imaginado. Com suas histórias mais longas, temáticas diferenciadas e público diverso, os quadrinhos alternativos acabaram criando um novo mercado: passaram a figurar nas prateleiras não só das lojas especializadas em quadrinhos, as comic book shops, mas também nas livrarias, ganhando um espaço reservado só para elas; editoras foram criadas exclusivamente para sua publicação e muitas outras se adaptaram para poderem usufruir desse mercado crescente; críticos, publicações e sites especializados surgiram. Entretanto, talvez a maior mudança causada pela invasão desses quadrinhos alternativos no mercado seja o fato de eles terem tomado para si, e em consequência 
cristalizado na mente do público em geral, um termo que passaria a designar, nas décadas seguintes, o que significa ser um "quadrinho de qualidade". O termo? Graphic novel.

Existem algumas tantas lendas que contam a história do surgimento das graphic novels no mercado quadrinístico estadunidense. Uma das mais difundidas e acreditadas é a de que Will Eisner (1995) teria cunhado o termo e lançado a primeira obra do tipo ao publicar Um contrato com Deus e outras histórias de cortiço, publicada originalmente em 1978, sendo o próprio autor o divulgador de tal "verdade" ao contá-la e recontá-la incontáveis vezes em entrevistas e eventos. Segundo Vergueiro (2009), na verdade Eisner não havia criado nada de novo, nem mesmo inventado a expressão, pois não se tratava da primeira vez que o termo era o utilizado para se referir a uma obra do tipo produzida em formato de quadrinhos. Antes de Eisner, o escritor John Updike, por exemplo, revelou em uma palestra, em 1960, que os romances poderiam tomar outras formas além da tradicional, e acrescentou que acreditava que um grande romance poderia ser escrito magistralmente em forma de história em quadrinhos (DUNCAN; SMITH, 2009, p. 70).

O termo graphic novel já era utilizado em outros países europeus, especialmente para designar os álbuns encadernados de histórias em quadrinhos que, à época, eram publicados no velho continente e que traziam em seu conteúdo histórias completas de personagens consagrados, como Tintin. Segundo Vergueiro (2009), foi com a publicação desses álbuns que Richard Kyle, crítico norte-americano e uma das vozes da comunidade das histórias em quadrinhos que crescia, cunhou, em 1964 o termo graphic story, que seria posteriormente substituído por graphic novel. Isso, porque segundo Kyle, trabalhos diferentes do mainstream já estavam sendo produzidos na Europa e o crítico desejava que o mesmo fosse feito nos Estados Unidos, almejando um futuro com mais prestígio para o campo e inspirando, assim, os autores norte-americanos a adotarem o mesmo nível de sofisticação de seus colegas europeus (VERGUEIRO, 2009, p. 25).

Contudo, tendo conhecimento da real origem do termo ou não, é inegável a importância de Will Eisner para a divulgação e popularização do termo em todo o mundo, pois sua importância, proeminência e influência no mundo dos quadrinhos foi de inestimável valor para a abertura e aumento do mercado para esse tipo de produção. 
Inclusive, defende Vergueiro (2009, p. 26), a aceitação desse tipo de trabalho estava diretamente ligada ao apoio às ideias de Eisner por parte de seus fãs, ideias essas baseadas na proposta de modificar os estereótipos em torno das histórias em quadrinhos. Isso, porque o autor buscava um título para seus trabalhos que os diferenciasse do que, até então, era publicado pela indústria norte-americana de quadrinhos. Por isso, no prefácio à primeira edição, o autor afirmava que a ideia havia surgido já na década de 1930, quando Esiner teria entrado em contato com histórias em quadrinhos mais longas, sem palavras e feitas em serigrafia. Ramos e Figueira (2011) lembram que o quadrinista creditou à sua própria obra um status de arte, estampando na capa da publicação a frase "um romance gráfico de Will Eisner" (ver figura 12). Essa terminologia, inclusive, acabou por estabelecer um diálogo entre o que ele havia produzido e o campo literário. Por isso, a repercussão da publicação pode ter contribuído para que a expressão fosse posteriormente adotada pelas editoras do mainstream (RAMOS; FIGUEIRA, 2011).

Figura 12 - Capa de Um contrato com Deus e outras histórias de cortiço, de Will Eisner

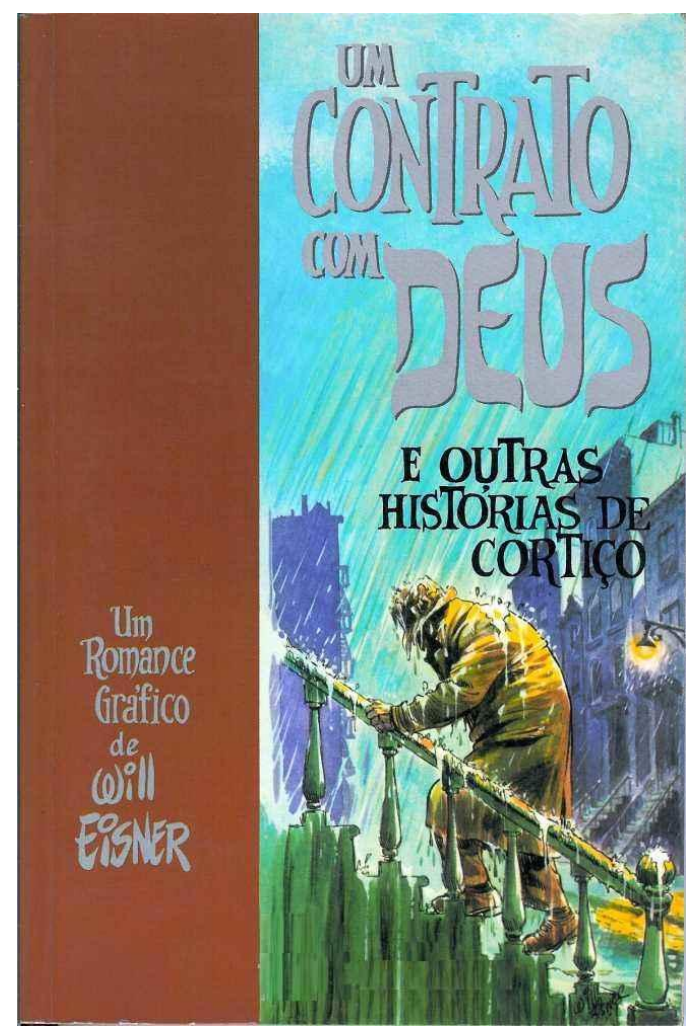

Fonte: Eisner (1995) 
Nesse sentido, vale lembrar que, por mais que os fatores que moldaram o desenvolvimento das graphic novels em solo norte-americano sejam tão diversos, controversos e múltiplos, uma coisa pode ser dita com certeza: sem a intervenção dos quadrinistas do movimento underground da década de 1960, as graphic novels não existiriam como as conhecemos hoje (BEATY; WEINER, 2012). É claro que não se pode dizer que os artistas das tiras dos jornais ou das revistas em quadrinhos anteriores à chegada do comix não tenham feito trabalhos magníficos. Entretanto, como vimos anteriormente, o movimento underground não tinha suas temáticas voltadas para o público infanto-juvenil, além de não privilegiar o lucro em suas publicações, e sim a oportunidade de dar voz ativa e criativa aos seus artistas; criou-se, assim, um espaço de expressão pessoal e política, um escape do mundo que os rodeava e um lugar onde poderiam experimentar, na forma e no conteúdo, como em nenhum outro ambiente, dando origem ao movimento alternativo.

A nova geração de quadrinistas que surgiu carregou com ela temas e estilos não tradicionais, interessados em um grupo particular de consumidores e trazendo consigo lojas especializadas, as comic book shops, que se espalharam pelo mundo. Espécie de híbrido entre o underground e o mainstream acabaram, com o passar do tempo, desenvolvendo seus próprios gêneros e tradições, entre elas a autobiografia, a história ficcional, a cobertura jornalística, etc. (BEATY; WEINER, 2012, p. xvi), que acabaram por ficar conhecidas como graphic novels. Aqui é importante lembrar que o que dissemos na primeira sessão deste capítulo acabou se concretizando nas chamadas graphic novels: os quadrinistas e entusiastas europeus forçaram a entrada de uma nova visão dos quadrinhos nos Estados Unidos, enquanto o movimento underground mudou a configuração do meio.

Entretanto, o que reconhecemos hoje como graphic novel se desenvolveu, em território norte-americano, nas décadas de 1980 e 1990 a partir da compilação de histórias serializadas. A grande maioria das obras consagradas da época, como Maus e Watchmen, foram lançadas primeiramente em partes para depois serem organizadas em um livro, lançando assim as bases para o que hoje conhecemos como graphic novels. Maus, por exemplo, teve sua primeira parte, intitulada Meu pai sangra história, lançada em 1986, e sua segunda parte, E aqui meus problemas começaram, em 1991. Já Watchmen teve seus 12 capítulos publicados mensalmente em formato de revista e vendidos na banca de jornal, para depois serem compilados e transformados em uma 
narrativa única, vendida como um livro. Essa reunião das histórias recebeu a terminologia de graphic novel quando foi colocada no mercado (RAMOS; FIGUEIRA, 2011).

Figuras 13 e 14 - Capas das duas edições de Maus, lançadas separadamente e depois compiladas
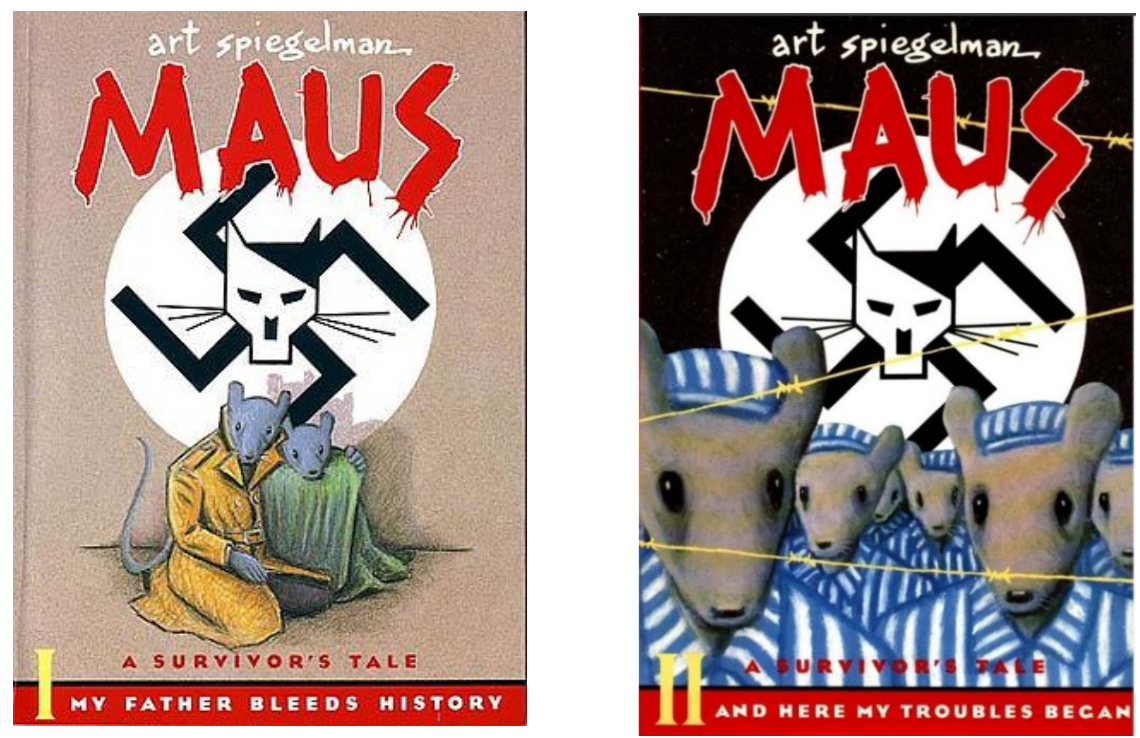

Fonte: Spiegelman (1986; 1991)

Figura 15: Capa do capítulo II de Watchmen. Publicada originalmente em doze edições mensais, foi posteriormente compilada e classificada como graphic novel

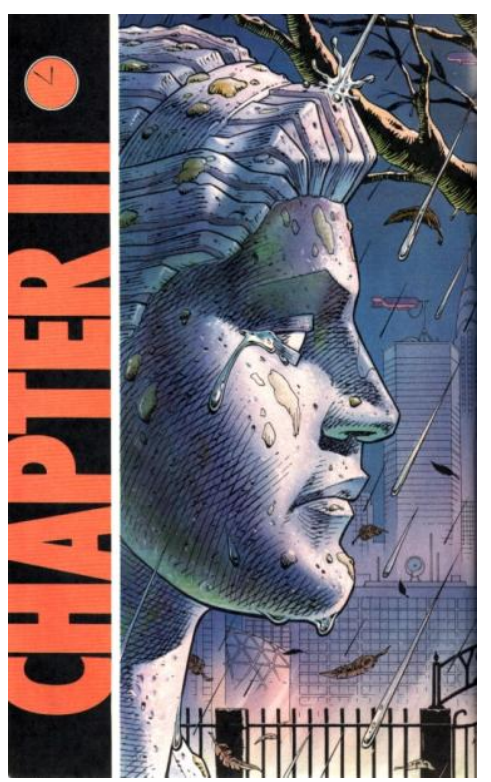

Fonte: Moore;Gibbons (2004) 
Entretanto, hoje as graphic novels, na maioria das vezes, já são pensadas por seus artistas e editores como uma única história em um único volume. Com isso, as histórias serializadas e depois compiladas perderam força e aquelas lançadas em um único volume se tornaram a norma. Obras hoje premiadas e reconhecidas, como Habib de Craig Thompson, Asterios Polip de David Mazuchelli, entre tantas outras, já chegam às mãos dos leitores como livros finalizados (BEATY; WEINER, 2012, p. xvi). Com isso, graphic novel passou a designar apenas as histórias mais longas, lançadas em formato de livro e que contam uma história com um arco fechado e com temáticas mais sérias e densas. Aliás, para Douglas Wolk (20007) se utilizarmos essas especificações para classificar um trabalho como uma graphic novel, Um contrato com Deus de Will Eisner não se encaixaria nessa premissa, pois consiste menos em um romance, com uma narrativa longa, e mais em uma coleção de quatro não-tão-longas histórias ligadas pela temática

Figuras 16 e 17: Habib, de Craig Thompson e Asterios Polip, de David Mazzucchelli: obras mais longas que já chegaram às mãos do público finalizadas
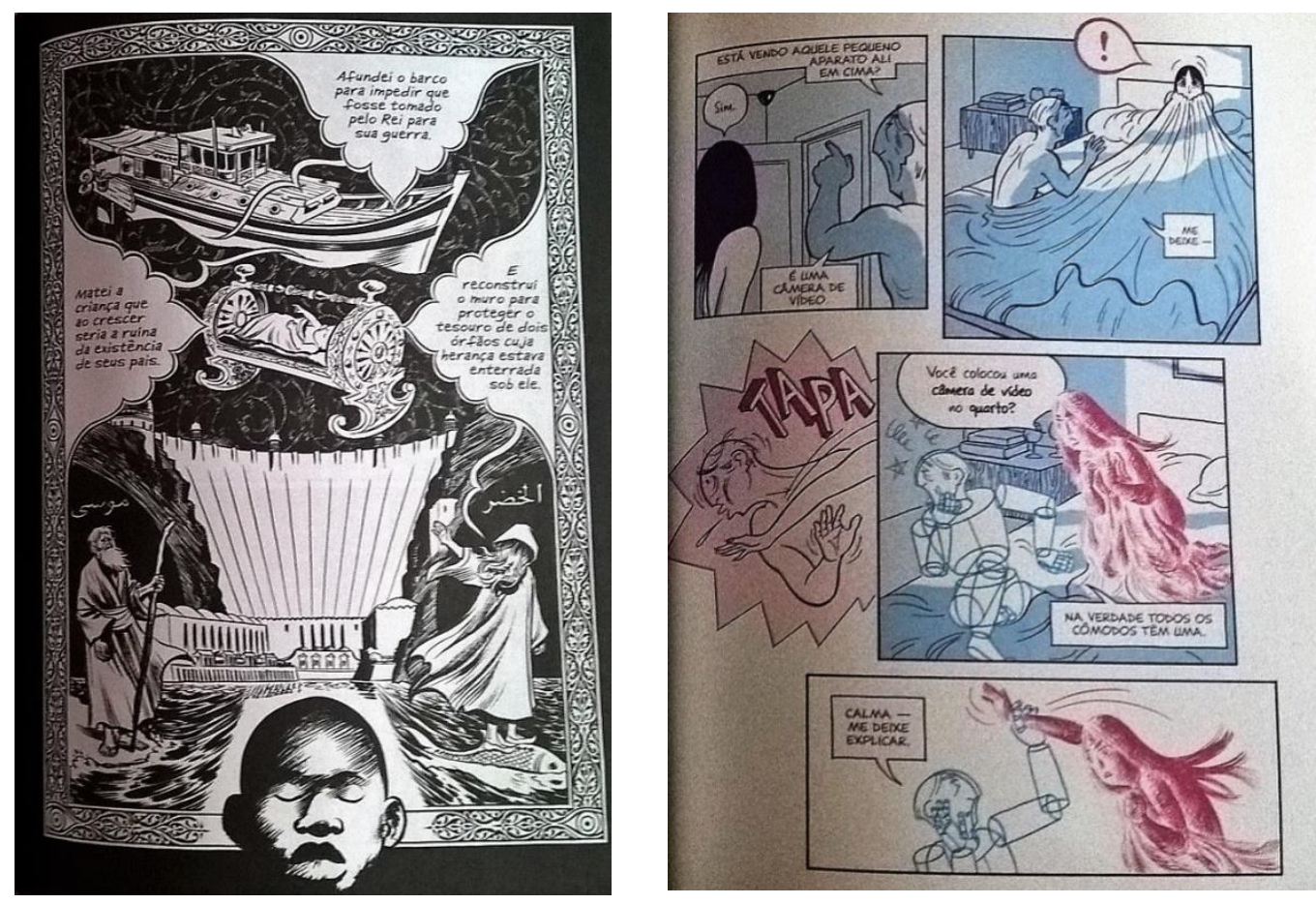

Fonte: Thompson (2012); Mazzucchelli (2011) 
Por designarem, então, apenas as obras em quadrinhos que são destinadas ao público adulto, e não mais ao infantil; por apresentarem qualidade editorial superior, e não mais impressas em papel barato; por serem editadas em formato de livro, e não de revista; e por serem vendidas nas livrarias e lojas especializadas, e não mais nas bancas de jornal, as graphic novels passaram a ser vistas pelo público em geral como a antítese de tudo o que era considerado ruim nas histórias em quadrinhos, transformando-se assim no suporte privilegiado no entendimento dos quadrinhos como um produto cultural valorizado, e não mais apenas como entretenimento de massa. $\mathrm{O}$ termo, assim, "[...] parece ter sido uma resposta própria da indústria do país a esse molde de criação de histórias em quadrinhos" (RAMOS; FIGUEIRA, 2011), tornando-se um conceito valorativo que delega status às histórias em quadrinhos em detrimento dos demais formatos, estes, agora, desconsiderados como trabalhos de qualidade. Ramos e Figueira (2011), dessa forma, resumem bem como se dá a distinção de um formato em relação ao outro dentro do campo:

\footnotetext{
Vale observar que, ao atribuir um "status" à nova produção de quadrinhos, mais adulta e madura, trabalha-se com o pressuposto de que o que foi criado na área até então não teria qualidade suficiente para tal. Embora possivelmente fosse não intencional, tal discurso tornou-se comum sempre que o tema vinha à tona e ajudava a criar uma espécie de hierarquia entre as publicações em quadrinhos: as pretensamente artísticas ou literárias e as demais (RAMOS; FIGUEIRA, 2011).
}

Assim, cria-se a ideia, seja para o público habitual de quadrinhos, seja para o esporádico, que esse tipo de publicação se diferencia dos demais agregando, dessa forma, valor positivo ao termo e, em consequência, ao produto (RAMOS; FIGUEIRA, 2011). Por conta disso, muitas das publicações que são denominadas de graphic novels recebem em suas capas, contracapas, orelhas, etc, o termo como forma de evidenciar que esse tipo de "conteúdo" será adquirido. Da mesma forma, a mídia e os críticos que se voltam a esse tipo de publicação utilizam a expressão com finalidades adjetivas, ou seja, adjetivam a obra como graphic novel a fim de exaltar seus aspectos positivos. Além disso, uma outra tendência, ressaltam Ramos e Figueira (2011), é a de adjetivar as graphic novels como "literárias", já que a literatura, ao contrário dos quadrinhos, é um campo enxergado, há séculos, como uma arte de prestígio e já há muito legitimada; 
antes ignorados pelas altas instâncias, os quadrinistas agora dividem espaço com os grandes escritores.

Todas essas questões implicadas no uso do termo graphic novel instantaneamente nos levam a pensar nele como designando algo sério e importante, ao contrário dos demais formatos. E isso, nos alerta Wolk (2007), deixa aberta a porta para qualquer um que queria colocar um "terno e uma gravata" na sua historinha (WOLK, 2007, p. 63). Inclusive, essa é uma das estratégias de grandes editoras, como a Marvel e a $D C$, que resolveram pegar histórias antigas de super-heróis mais longas, editá-las em capa dura e em papel especial e vendê-las a preços elevados nas livrarias quando, originalmente, eram vendidas por centavos nas bancas, enquanto ainda eram chamadas de "histórias em quadrinhos", e não de "graphic novels".

Em resenha do livro A Novela Gráfica, de Santiago García, Ediliane Boff (2012) nos traz certa luz no que diz respeito às nossas ressalvas em relação ao termo graphic novel. Nela, a pesquisadora afirma, logo no início, que é bastante comum, quando se fala em leitura, certo fetichismo em relação a um de seus muitos suportes: o livro. Ícone máximo da literatura, o livro seria o suporte principal desta forma narrativa de grande prestígio e objeto de uma "verdadeira leitura". Isso dito, Boff (2012) exemplifica que as chamadas "novelas gráficas" (as graphic novels) acabaram inclusas no fetiche do livro: com elas, os quadrinhos tornaram-se mais legitimados, o que cai como uma luva para um público leitor que não quer ser associado à leitura dos outros tipos de quadrinhos, ou seja, os massificados e voltados para o público infanto-juvenil. Esse apelo que o livro tem também está ligado ao seu caráter duradouro, resistente, feito para ser armazenado na estante e admirado por anos a fio. A revista, ao contrário, é normalmente mais efêmera, produzida e consumida sem o intuito de ser guardada para a posteridade (MARTINS, 2001). Fiedler (1957) ainda reforça essa ideia ao ironizar com o fato de que

[...] os artigos da cultura popular não são feitos para ser guardados, mas para ser atirados fora; um livro brochado de histórias em quadrinhos é como uma fralda que não presta mais ou um saquinho vazio de leite. Apesar de todo o seu competente acabamento, não pode ser preservado em prateleiras empoeiradas, como os volumes encadernados em couro de outros tempos; com efeito, o seu próprio modo de existência desafia a concepção da biblioteca, particular ou pública (FIEDLER, 1957, p. 626). 
Assim, Boff (2012) compreende que a supervalorização das graphic novels é cada vez maior, já que esse título dado a essas histórias enobreceria um meio que por muito tempo foi considerado ruim. Com essa nova nomenclatura, os quadrinhos podem, finalmente, ganhar prestígio e fazer parte de espaços como museus, galerias e outras mídias em geral, locais que sempre os excluíram. Graças às graphic novels, os quadrinhos magicamente podem ser colocados ao lado dos grandes e legitimados campos de produção cultural, como a literatura e as artes plásticas. O termo, assim, funciona como uma forma de substituição "gentrificada dos quadrinhos". (BEATY, 2012, p. 34) O próprio Art Spiegelman, considerado por muitos como o pai da graphic novel moderna - ao que o quadrinista rebate, exigindo um teste de $\mathrm{DNA}^{15}$-, desgosta do termo. Em suas palavras, o termo existe como

[...] um dos eufemismos que as pessoas têm usado para dizer que os quadrinhos não são um prazer cheio de culpa. Gráfico: meio que respeitável. Romances: desde o século XIX, muito respeitáveis. Então as graphic novels são duplamente respeitáveis. Quando estava crescendo você não poderia dizer que era um quadrinista porque era como dizer: como vai você? $\mathrm{Eu}$ sou um caso de retardo no desenvolvimento. E agora ser um "romancista gráfico" te dá um certo prestígio (SPIEGELMAN, 2014, p. 25-26, tradução nossa) ${ }^{16}$.

Joe Sacco, quadrinista consagrado e autor de obras com Palestina, também já se pronunciou sobre o assunto e também questiona o termo graphic novel. Para ele, o mesmo soa como uma tentativa de fazer com que os quadrinhos pareçam ter "[...] realmente crescido. Mas nós somos o que somos... Quadrinhos são quadrinhos. Não me sinto envergonhado - então não preciso de outro par de palavras para me fazer sentir como se estivesse fazendo algo que valha a pena" (SACCO apud WILLIAMS; LYONS, 2010, p. xv, tradução nossa ${ }^{17}$ ). Continuando nessa linha, Williams e Lyons (2010) colocam que o conceito das graphic novels, ao servir principalmente para atrair o

\footnotetext{
${ }^{15}<$ http://www.bostonmagazine.com/arts-entertainment/blog/2014/05/12/art-spiegelman-bostonwhat-happened-to-comics/> Acesso em 21 nov. 2016

${ }^{16}[\ldots]$ one of the euphemisms that people have used to say that comics are not a guilty pleasure. Graphics: sort of respectable. Novel: since the nineteenth century, very respectable. So graphic novels are doubly respectable. When I was growing up you couldn't say you were a cartoonist because it is like saying, how do you do? I'm a case of arrested development. And now being a "graphic novelist" has a certain caché.

${ }^{17}[\ldots .$.$] really grown-up. But we are what we are... Comics is comics. I don't feel ashamed - so I don't$ need another couple of words to make me feel like I'm doing something worthwhile."
} 
público adulto, que se sente seduzido pelo formato do livro e pela qualidade do papel em que essas histórias são vendidas, fez dos quadrinhos um objeto de desejo muito maior, assim como um produto mercadológico mais rentável e que pode ser exposto e comercializado nos "espaços sagrados" habitados apenas pelos grandes artistas.

Nesse sentido, é impossível não enxergar que existe uma relação direta entre o desenvolvimento desse mercado nos Estados Unidos e o gradual aumento da legitimação cultural dos quadrinhos. Para Bart Beaty (2012), não existem dúvidas de que as lojas especializadas na venda de quadrinhos, as comic book shops, foram por muito tempo estigmatizadas como um lugar para pessoas antissociais e tímidas e para os colecionadores. Contudo, o desenvolvimento dessa rede de vendas que facilitou a publicação e o acesso a trabalhos que começaram a fugir do usual abriu caminho para as novas possibilidades de produção que seriam financeiramente arriscadas, ou mesmo impossíveis, se permanecessem no sistema de distribuição das bancas de jornal.

Beaty (2012) vai mais além e afirma, com bastante veemência, que, apesar de suas origens e base de consumidores já bem estabelecidas, os quadrinhos só iniciam sua jornada em direção à legitimação cultural quando essa forma de distribuição se desenvolve. Com a criação desse sistema de vendas ainda nos anos 1970, ele pontua, ficou mais fácil enxergar os quadrinhos não como parte da cultura de massa impressa como acontecia quando eles dividiam o espaço da banca de jornal com as revistas e jornais -, e sim como uma forma de arte distinta (BEATY, 2012, p. 43). Sendo as graphic novels as grandes beneficiárias do processo, é possível destacar que, na medida em que os quadrinhos passaram a ganhar respeitabilidade no universo das artes consagradas, do qual nunca imaginou fazer parte, certa "hierarquia da qualidade" foi criada para distinguir os quadrinhos: de um lado os kitsch e de outro a face sofisticada e experimental dos quadrinhos (SJÅSTAD, 2015, p. 06).

O meio editorial, assim, acaba atribuindo às graphic novels uma característica de distinção, de um produto superior e diferenciado dos demais suportes de histórias em quadrinhos, atribuindo valor ao produto em si, e não ao tema ou à qualidade da história. Nessa linha, Ramos e Figueira (2011) afirmam entender que o termo graphic novel seja um recuso editorial utilizado para se referir a certas produções, especialmente as norteamericanas, que narram histórias mais longas, muitas vezes biográficas e autobiográficas, funcionando como um rótulo que é aceito comercialmente e, por isso, 
amplamente alastrado. Entretanto, afirmam os autores, tal rótulo acaba por ofuscar quais são as reais características da história.

Para Ramos e Figueira (2011), o uso de graphic novel pelas editoras, ao disseminá-lo em capas, contracapas, textos informativos, entre outros, como forma de divulgação da obra, tem ajudado na divulgação do termo, ao mesmo tempo em que, segundo os autores, “[...] constrói uma aparente zona nebulosa sobre do que realmente se trata: uma forma moderna de como produzir quadrinhos, um gênero destes ou ainda algo mais?” (RAMOS; FIGUEIRA, 2011). Por isso, para Ramos e Figueira (2011), "há mais fatores que influenciam na forma de recepção de uma obra do que o próprio conteúdo em si” (RAMOS; FIGUEIRA, 2011). O uso do termo graphic novel tão indiscriminadamente, sem a explicação do que significa, acabou gerando a ideia de que essa forma de publicação se trata de um gênero, ou seja, como se graphic novels fossem um gênero à parte que nada tem a ver com as histórias em quadrinhos como até então as conhecíamos.

Segundo Ramos e Figueira (2011), uma das coisas que reforça essa ideia é o fato de muitas dessas obras tratarem de experiências pessoais ou autobiográficas, algo que é relativamente novo no campo, o que, em tese, as configuraria como um novo gênero. Beaty e Weiner (2012), inclusive, comentam a explosão das graphic novels no mercado das livrarias, chamando-as de um "importante gênero" (BEATY; WEINER, 2012, p. xvi). Entretanto, discordamos da ideia de que as graphic novels constituem um gênero. Elas na verdade seriam um suporte editorial, do qual muitos gêneros poderiam fazer parte. Tentaremos demonstrar, a seguir, porque consideramos as graphic novels como um suporte editorial e não um gênero.

No livro Graphic Novels: everything you need to know, Gravett (2005) faz um levantamento das graphic novels essenciais e que todos deveriam ler. O autor explica que a escolha pelas obras consideradas por ele como indispensáveis, como uma espécie de "lista básica" para se iniciar nesse universo, se deu a partir da ênfase na história da obra, no seu conteúdo, por achar que essa é a prioridade das pessoas quando buscam uma história publicada nesse formato. Para criar essa lista, utilizou alguns critérios: as obras deveriam ter sido publicadas na língua inglesa, mesmo que possuam outra língua de origem; terem sido publicadas recentemente e que estivessem ainda disponíveis para compra e, portanto, fáceis de achar; que fossem histórias originais, entre outros critérios. 
Entretanto, dois pontos levantados por Gravett (2005) como importantes para a seleção que faz em seu livro chamam a atenção: o primeiro é de que escolheu apenas histórias publicadas em formato de livro. $\mathrm{O}$ autor justifica esse critério ao dizer que, apesar de graphic novels poderem existir em partes ainda não compiladas, e até mesmo em manuscritos não publicados, sua ênfase é na disponibilidade das obras. Em suma, para que ele considere uma obra como fundamental, ela já deve ter sido publicada em formato de livro, desconsiderando, mesmo que as nomeie da mesma forma, as demais. O segundo ponto que se destaca na descrição de Gravett é que ele privilegiou histórias que tenham começo, meio e fim, no lugar de histórias serializadas que não tenham ou talvez não venham a ter um final concreto, uma conclusão (GRAVETT, 2005, p. 08/09).

Esses dois critérios utilizados por Gravett (2005) para a seleção das obras que considera fundamentais demonstram que as graphic novels são enxergadas como um livro fechado, ou seja, como uma história acabada. Devemos ressaltar que não entraremos nesse momento no mérito do livro como fetiche, como explicitado anteriormente. $\mathrm{O}$ que queremos demonstrar é que ao considerar obras que tenham sido publicadas apenas em formato de livro, Gravett reforça a nossa ideia de que graphic novels, na verdade, constituem um suporte editorial, e não um gênero. $\mathrm{O}$ autor deixa isso claro, mesmo sem intencionar, ao afirmar que o termo novel ("novela"), faz com que o público espere um certo tipo de formato, com intenções sérias, pensado a partir das premissas da literatura tradicional, como se graphic novel devesse significar o equivalente a um trabalho de ficção extenso. Entretanto, ressalta Gravett (2005), muitas delas não são consideradas ficcionais, e sim pertencem às categorias da não-ficcção: história, biografia, reportagem, documentário ou educacional. Ou seja, as graphic novels não se limitam a apenas um gênero, ao mesmo tempo em que não são exatamente o que se espera de fato de um romance literário; são, sim, seu próprio formato. (GRAVETT, 2005, p. 08). A concepção de gêneros do discurso de Mikhail Bakhtin (1997) nos ajudará a entender melhor o porquê de considerarmos as graphic novels como um suporte editorial e não como um gênero.

Segundo Bakhtin (1997), por mais variedades que contenham, todas as esferas da atividade humana estão ligadas à utilização da língua. Maior exemplo disso é que o caráter e os modos de utilização são tão variados quanto as próprias esferas desta atividade. Nesse sentido, a forma como se utiliza a língua pode ser feita por meio de enunciados concretos e únicos, sejam eles orais ou escritos, procedidos pelos integrantes 
de determinada esfera da atividade humana. O enunciado, definido por Bakhtin como a unidade da comunicação verbal, é o que reflete as condições específicas e as finalidades de cada uma dessas esferas, não só por seu conteúdo temático e estilo verbal, mas também por sua construção composicional. Esses três elementos elencados por Bakhtin (1997) - o conteúdo temático, o estilo e a construção composicional -, todos caracterizados por determinadas especificidades de uma esfera da comunicação, se fundem para formatar o enunciado. Qualquer enunciado, afirma o autor, é individual. Entretanto, cada esfera de utilização da língua desenvolve seus "tipos relativamente estáveis" de enunciados, que são então definidos por Bakhtin como os "gêneros do discurso" (BAKHTIN, 1997, p. 277).

Levando-se em consideração todos esses pressupostos, Bakhtin (1997) ressalta que a variedade dos gêneros do discurso é infinita, visto que a variedade da atividade humana também o é. Desse modo, cada uma das esferas da atividade humana possui um repertório de gêneros do discurso que modifica-se e amplia-se na medida em que essa própria esfera se desenvolve e se complexifica. Os gêneros do discurso, sejam orais ou escritos, são em sua essência extremamente heterogêneos e é por isso que é tão complicado definir o caráter genérico de um enunciado. Por conta da grande heterogeneidade de gêneros do discurso, o autor estabelece uma classificação para dividi-los em dois tipos: os gêneros primários e os gêneros secundários.

Os gêneros primários são aqueles caracterizados como os mais simples, isto é, as situações comunicacionais mais espontâneas, informais e cotidianas. Já os gêneros secundários são mais complexos ao se estabelecerem, normalmente, por meio da escrita em situações comunicacionais mais complexas e sofisticadas, como o romance e o teatro, por exemplo. Entretanto, Bakhtin (1997) ressalta que tanto os gêneros primários quanto os secundários são constituídos por fenômenos da mesma natureza, no caso os enunciados verbais. O que os diferencia, portanto, é o seu nível de complexidade. Nas palavras de Bakhtin,

Os gênero secundários do discurso - o romance, o teatro, discurso científico, o discurso ideológico, etc. - aparecem em circunstâncias de uma comunicação cultural, mais complexa e relativamente mais evoluída, principalmente escrita: artística, científica, sociopolítica. Durante o processo de sua formação, esses gêneros secundários absorvem e transmutam os gêneros primários (simples) de todas as 
espécies, que se constituíram em circunstâncias de uma comunicação verbal espontânea. Os gêneros primários, ao se tornarem componentes dos gêneros secundários, transformam-se dentro deles e adquirem uma característica particular: perdem sua relação imediata com a realidade dos enunciados alheios - por exemplo, inseridas no romance, a réplica do diálogo cotidiano ou a carta, conservando sua forma e seu significado cotidiano apenas no plano do conteúdo do romance, só se integram à realidade existente através do romance considerado como um todo, ou seja, do romance concebido como fenômeno da vida literário-artística e não da vida cotidiana. (BAKHTIN, 1997, p. 281)

Segundo Bakhtin (1997), os gêneros sofrem modificações dependendo do contexto histórico em que se encontram, ou seja, cada situação social origina um gênero que possui características específicas de tal momento histórico, aos quais correspondem determinado estilo. $\mathrm{O}$ estilo está, segundo o autor, diretamente ligado ao enunciado e às formas típicas dos gêneros do discurso. $O$ enunciado, em qualquer esfera da comunicação verbal, é individual e, por isso, pode refletir a individualidade de quem o produz; o enunciado possui, portanto, um estilo individual. Entretanto, nem todos os gêneros estão aptos a refletir a individualidade. Por isso, a variedade de gêneros do discurso pode revelar, ao mesmo tempo, a variedade das características da personalidade individual, ao passo que o estilo individual pode relacionar-se de modos diferentes com a língua comum. Além disso, “[...] o estilo linguístico ou funcional nada mais é senão o estilo de um gênero peculiar a uma dada esfera da atividade e da comunicação humana.” (BAKHTIN, 1997, p. 283)

Assim, cada esfera da atividade humana conhece, levando em consideração suas especificidades e estilos correspondentes, seus próprios gêneros. Dependendo da função - seja ela científica, técnica ou cotidiana - e das condições específicas de cada uma das esferas da comunicação verbal, determinado gênero é criado. Considerando que existe uma infinidade de situações comunicativas possíveis graças à utilização da língua, então os gêneros também se constituem como infinitos. Bakhtin, desse modo, faz uma relação direta entre a formação de novos gêneros e o aparecimento de novas esferas da atividade humana que contem em si finalidades discursivas específicas: quando ocorrem mudanças históricas dos estilos da língua, ao mesmo tempo ocorrem mudanças nos gêneros do discurso. Em suma, os gêneros do discurso refletem toda e qualquer mudança na vida social (BAKHTIN, 1997, p. 285). 
Nos parece que, na definição de Bakhtin (1997), o campo dos quadrinhos se constituiria como um gênero do discurso secundário, ao passo que os diferentes gêneros contidos em uma obra - aventura, super-heróis, autobiografia, etc., - seriam os gêneros primários. Uma outra forma de se enxergar essa premissa seria a partir da noção utilizada por Paulo Ramos (2009b) - que será melhor explicitado no decorrer da pesquisa - que, baseando-se na ideia de "hipergênero" de Dominique Maingueneau, estabelece os quadrinhos como um "hipergênero" que contém dentro de si uma variedade de gêneros.

E é por isso que defendemos que graphic novels não constituem-se como um gênero. Isso, porque, acreditamos, a única coisa que diferentes publicações que recebem essa alcunha têm em comum é o formato em que são produzidas e posteriormente impressas, ou seja, em formato de livro. Por exemplo: se levarmos em consideração os postulados de Bakhtin (1997), as graphic novels não sofrem modificações de acordo com o contexto histórico, refletindo as mudanças na vida social; o que se modifica são os gêneros que nela se apresentam. Assim como coloca Bakhtin (1997), reforçado pelo que foi proposto por Gravett (2005), as graphic novels podem conter uma infinidade de gêneros diferentes. $\mathrm{O}$ fato de mais de uma obra ser designada como tal não faz de todas as outras obras que recebem essa denominação como pertencentes ao mesmo gênero. Seria o mesmo que dizer que uma revista em quadrinhos de super-heróis e outra de terror fazem parte do gênero "revista em quadrinhos" simplesmente por terem sido publicadas por meio do mesmo suporte editorial.

Adotaremos uma outra perspectiva para tentar demonstrar o porquê de as graphic novels constituírem um suporte editorial. Para tal, utilizaremos os relatos de quatro dos grandes "romancistas gráficos" da atualidade: Charles Burns, Daniel Clowes, Seth e Chris Ware, todos reconhecidos no campo dos quadrinhos e fora deles, com obras aclamadas pelo público e pela crítica. No painel Graphic Novel Forms Today, realizado dentro da conferência Comics: Philosophy and Practice, que aconteceu em 2012 na Universidade de Chicago, os quatro foram chamados para falar sobre seus trabalhos. Hilary Chute, moderadora da conversa, pergunta aos quadrinistas o que eles acham do formato livro - este o formato utilizado na edição de suas obras, chamadas de graphic novels. Os quatro artistas responderam à pergunta. 
Para Seth, o que o formato de livro permite, como nenhum outro, é que a história pode ser desenvolvida pelo autor, e em consequência lida pelo consumidor, sem nenhuma pressa. Além disso, o formato permite uma série de ousadias em relação ao estilo, como inserir uma fotografia no meio da narrativa, por exemplo. Para Seth, o livro possibilitou o uso desse tipo de ferramenta, além de dar maior liberdade ao quadrinista quanto ao tamanho da obra que pretende criar e a forma que ela será apresentada. "Então, sim, é bastante excitante poder trabalhar com livros. [...] Começando nos anos 1980 e depois seguindo em frente eu acho que mais quadrinistas começaram a entender que a situação não se resume a 'eu preciso terminar essa história e preciso que alguém a enfie em algum livro"” (SETH in CHUTE; JAGODA, 2014, p. 156, tradução nossa) ${ }^{18}$.

Daniel Clowes, quando perguntado do porquê de não enveredar pelo universo dos web comics, respondeu que seu processo criativo se assemelha muito ao de uma escultura: quando começa, não pensa como vai funcionar ou como vai ficar o quadrinho, mas que depois de um tempo o que ele quer fazer começa a cristalizar em sua mente. Quando isso acontece, já começa a imaginar o objeto final como algo palpável, o que o web comic não permite. "Por isso que não sou atraído pelo formato, porque quero ver o livro e senti-lo. Isso é o que espero, a caixa da gráfica.” (CLOWES in CHUTE; JAGODA, 2014, p. 153, tradução nossa) ${ }^{19}$ Além disso, Clowes afirma que tinha aquela sensação de que nunca seria possível fazer quadrinhos em um tamanho diferente. Agora, com o livro, é possível. Nesse sentido, quando perguntado sobre Wilson, um de seus livros, Clowes respondeu:

Aquele livro em particular tem um certo sentimento de ser à prova de balas. Você meio que sente que ele ainda estará por aí quando chegar a próxima era do gelo. Esse será como o único livro que sobrou porque recebeu uns 5 centímetros de capa dura. É como se você se sentisse protegido, e você quer que ele tenha, sabe, uma concha que o permita permanecer no mundo (CLOWES in CHUTE; JAGODA, 2014 , p. 154 , tradução nossa $)^{20}$.

\footnotetext{
${ }^{18}$ So, yes, it is axciting to be able to work with books. [...] But starting in the 1980 s and then moving on I think more cartoonists have started to understand the situation is not simply, "I need to finish this story and have somebody stick it into a book."

${ }^{19}$ That's why I'm not excited about that format," because I want to see that book and feel it. That's the thing I'm waiting to get, that box form the printer.

${ }^{20}$ That book in particular has a certain bulletproof quality. You just feel, like, this is going to be around when the next ice age hits. This will be like the one book that survived because it's [got] the two-inch-
} 
Charles Burns, autor de Black Hole, ao ser questionado sobre a possibilidade de algo se perder quando a obra é publicada em formato de livro, responde que esse não foi o seu caso. Para ele, a obra foi lançada em uma época em que um número grande de graphic novels foi publicado e, por isso, o termo já havia sido absorvido e entendido pelo público em geral. Mas, segundo Burns, lançar sua obra como uma graphic novel “[...] não foi uma decisão consciente da minha parte. É como se eu quisesse contar uma história mais longa e aí saiu naquele formato (BURNS in CHUTE; JAGODA, 2014, p. 155, tradução nossa) ${ }^{21}$. Já para Chris Ware, “[...], os livros são a metáfora perfeita para uma pessoa: eles têm uma espinha dorsal e são maiores por dentro do que são por fora, assim como nós somos. Além disso eles também podem mentir pra você" (WARE in CHUTE; JAGODA, 2014, p. 155, tradução nossa) $)^{22}$.

As falas desses quadrinistas demonstram, de certa forma, que os próprios autores consideram as graphic novels como um suporte editorial. Nenhum deles, em nenhuma das falas, afirma ter inventado um novo gênero ou nada parecido, nem mesmo que eles são os novos representantes de um gênero que há pouco havia sido inventado. Relatam apenas que realizam as suas histórias de uma vez só, e não serializadas, que a edição em formato de livro, e não de revista, permite a eles possibilidades criativas que outros suportes não permitem. Para eles, é preferível demorar anos realizando um trabalho que será lançado em apenas um volume do que lançar a mesma história publicada em partes. $\mathrm{Na}$ fala desses artistas, o livro é quase um fetiche; um desejo alcançado; um sonho realizado. Afinal, ir à estante e pegar um livro seu, com seu nome escrito, deve ser de fato uma sensação incrível.

Assim, cremos, as graphic novels não constituem um gênero, mas sim um suporte editorial, e o seu formato é semelhante ao do livro. As graphic novels, na verdade, criaram e ajudaram a popularizar alguns gêneros, como a biografia, a autobiografia, o jornalismo em quadrinhos, entre outros, que, até a explosão desse novo tipo de suporte, não haviam sido possíveis porque os demais formatos limitavam o processo criativo. Entretanto, se pararmos para pensar, nada impede um autor de lançar uma autobiografia em vários volumes ou a cobertura de um conflito em formato de

thick cardboard on the cover. It is like you protective, and you want it to have, you know, a shell that can allow it to preceed in the world.

${ }^{21}[. .$.$] it wasn't a conscious decision on my part. It is like I wanted to tell a longer story and it came out in$ that format.

${ }^{22}$ [...] books, they are a perfect metaphor for a person: they have a spine and they are bigger on the inside than they are on the outside, just like we are. Plus they can also lie to you 
jornalismo em quadrinhos ser publicada mensalmente. Sabemos, é claro, que o processo criativo desses gêneros que se desenvolveram graças a popularização das graphic novels demanda muito tempo, mas nem por isso estão necessariamente presos ao formato, assim como outros gêneros mais tradicionais do campo das histórias em quadrinhos, como os quadrinhos de super-heróis, os policiais, de aventura, etc, não estão limitados ao suporte da revista, ou mesmo as tiras não estão limitadas aos jornais.

Um exemplo disso é a história Terapia, de Mario Cau, Rob Gordon e Marina Kurcis (2017). Lançada originalmente como um webcomic, fez tanto sucesso entre o público leitor que acabou ganhando uma versão impressa em 2013, conseguida graças ao financiamento coletivo. A obra, que narra a história de um garoto que, apesar da vida normal, não consegue alcançar a felicidade e, por isso, recorre à terapia para explorar suas inseguranças, transitou com facilidade entre o suporte digital e o impresso, não perdendo a qualidade e nem mesmo as características do gênero que o constitui. O que queremos dizer é que, no final das contas, os gêneros podem, sim, transitar entre os diferentes suportes editoriais, o que não quer dizer que um suporte editorial constitua um gênero. 
Figura 18 - Extrato do segundo volume de Terapia, disponibilizado na internet. O primeiro volume ganhou versão impressa pela editora Novo Século.

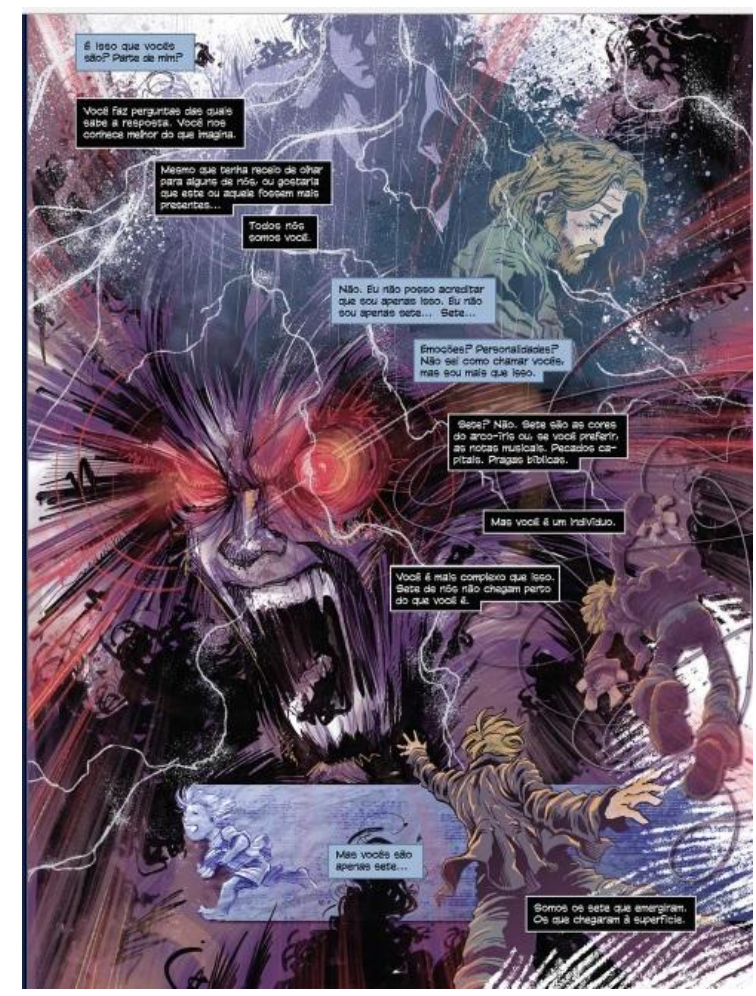

Fonte: Cau, Gordon e Kurcis (2017, p. 162)

Para Ramos e Figueira (2011), inclusive, as graphic novels funcionariam como uma espécie de "etiqueta" que definiria o conteúdo da obra:

Seguindo essa linha de raciocínio, evidencia-se uma separação entre o conteúdo e as características de composição e estilo do formato onde a história circula. $\mathrm{O}$ molde editorial pode ser por meio de uma revista ou de um livro, sendo este chamado álbum, graphic novel ou mesmo livro. Se o suporte for virtual, muda-se o modo de leitura, mas não necessariamente o gênero. Vê-se, então, que a graphic novel funciona como uma espécie de etiqueta sobre aspectos do conteúdo, mais maduro e direcionado a um leitor adulto e supostamente apreciador de livros. Esse rótulo, muitas vezes traduzido como romance gráfico, funciona como uma capa, que ofusca as reais características do gênero apresentado. (RAMOS; FIGUEIRA, 2011)

Entretanto, nossa discussão aqui não se resume só a uma crítica às graphic novels. É preciso, é claro, valorizar o que elas trouxeram ao meio. O conjunto de obras 
lançadas nas últimas décadas, consequência do início do processo de valorização das histórias em quadrinhos, ainda na década de 1960, passando por Maus, de Art Spiegelman, demonstra o avanço qualitativo do meio, inclusive no mercado mainstream. As graphic novels deram espaço para que os artistas explorassem novas temáticas e propostas que antes seriam inimagináveis. Tal foi a mudança que surgiram trabalhos que anteriormente jamais poderiam ter sido pensados em formato de quadrinhos, acabando com a ideia de que os quadrinhos são um campo com uma linguagem limitada, trazendo ao público desde as (auto)biografias até a cobertura de guerras e conflitos. Com suas raízes no underground, e impulsionados pela nova visão positiva trazida da Europa, os quadrinhos alternativos atingiram um grau de qualidade altíssimo. Até mesmo os gêneros mais tradicionais, como os super-heróis, ganharam uma nova faceta, revitalizando suas histórias e desenhos. Nesse sentido, apesar das ressalvas quanto à hiper valorização do termo é possível dizer que as graphic novels vieram a

[...] influir positivamente no ambiente dos quadrinhos no mundo inteiro, predispondo leitores e críticos não só a uma nova forma de publicação de histórias em quadrinhos, mas, também, a uma nova formulação artística para o gênero. Tratava-se de uma nova maneira de viabilizar e disseminar os quadrinhos [..] (VERGUEIRO, 2009, p. 26).

Figuras 19 e 20: Epiléptico, de David B. e Black Hole, de Charles Burns, histórias que se privilegiaram e que talvez não fossem possíveis sem o novo suporte.
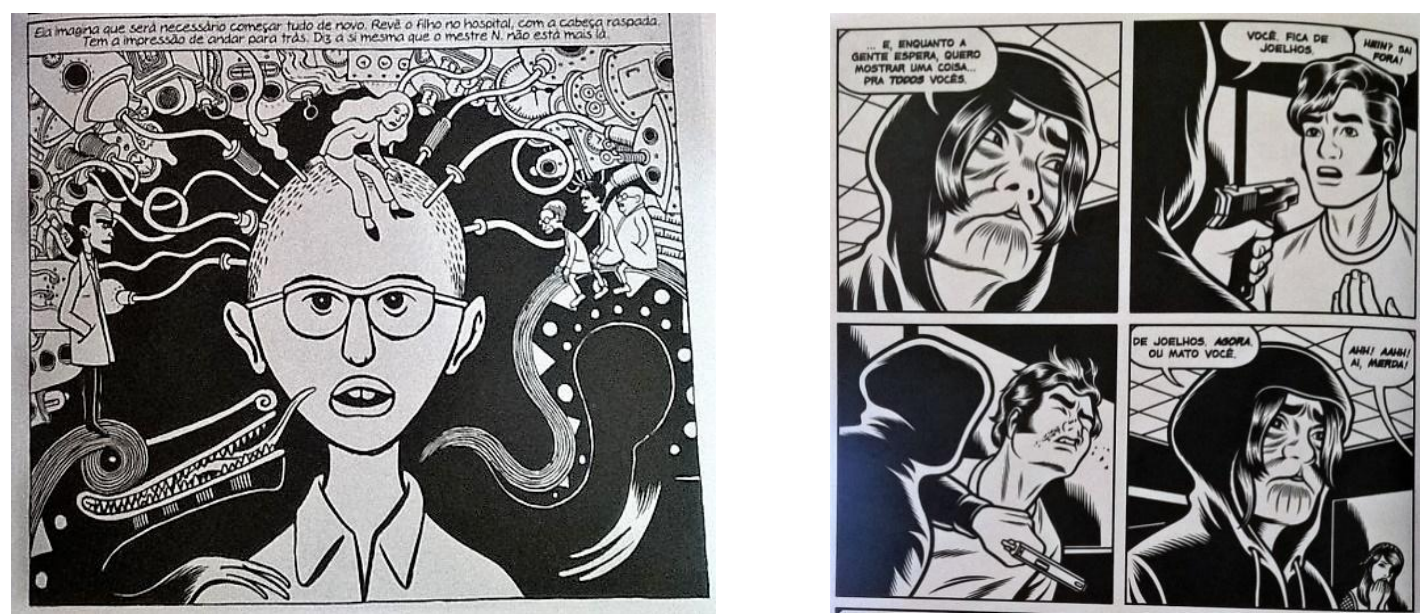

Fonte: B. (2007); Burns (2008) 
Inclusive, lembra Vergueiro (2007), não há dúvidas de que as histórias em quadrinhos, nas últimas décadas, tiveram que passar por muitas transformações para que se adaptassem à nova realidade do mundo ocidental. Com o desenvolvimento de outras tecnologias da informação e da comunicação, surgiu uma grande concorrência entre os meios de comunicação de massa que se desenvolveram no século $\mathrm{XX}$, especialmente com a televisão; nessa briga, as histórias em quadrinhos quase sempre saíram perdedoras. Entretanto, essa concorrência forçou a indústria produtora dos quadrinhos a buscar alternativas que pudessem fazer frente a essa nova concorrência, o que levou à diversificação de seus produtos e, consequentemente, de seu público (VERGUEIRO, 2007, p. 01). Com o novo entendimento do papel dos quadrinhos na sociedade, inclusive pela diminuição do preconceito relacionado ao meio e a visão de que eram voltados apenas para o público infanto-juvenil, o campo passou por grandes e necessárias transformações, e as graphics novels são parte fundamental desse processo.

Assim, por mais que discordemos da valorização deste suporte em detrimento dos demais, como se só ele fosse digno de ser aceito social e culturalmente, é inegável a importância dele para o processo de legitimação cultural dos quadrinhos. Após a invasão do mangá no mercado ocidental e o alcance de Maus, de Art Spiegelman, a produção das graphic novels se intensificou, o que levou as editoras a disponibilizar obras criadas especialmente para o novo formato, surgindo assim quadrinhos que, mais tarde, se mostrariam de capital importância na revitalização do meio. Vergueiro resume bem essa situação ao afirmar que

A nova denominação ajudou a abrir as portas de outros espaços de comercialização e exposição para as produções quadrinísticas, elevando-as a um novo patamar no espectro das criações artísticas no último quarto do século 20 e início do século 21. Mais que isso: como formato de produção, as graphic novels tornaram possível quebrar a barreira entre os quadrinhos industrializados e os alternativos, criando condições para um mercado diferenciado, em que a qualidade artística, o aprofundamento psicológico, a ousadia do design e a complexidade temática passaram a ter seu valor melhor equacionado. Pode-se dizer que, a partir delas, as histórias em quadrinhos e firmaram como 9a arte ou como Arte Sequencial (VERGUEIRO, 2009, p. 27-28). 
Assim, mesmo pensando-as criticamente, as graphic novels permitiram um novo olhar sobre as histórias em quadrinhos, mas a o processo de valorização não pode se ater apenas a elas. Entender os quadrinhos como um produto cultural valorizado e legítimo não pode ser limitado apenas por um suporte editorial; esse processo deve abarcar todo o meio. Um dos problemas que levantamos, inclusive, é que não é só o uso da expressão que cria a distinção valorativa das graphic novels, mas também a relação de seu conteúdo com elementos literários ou artísticos, ou seja, a adjetivação das obras como "artísticas" ou "literárias", considerando que os campos das artes plásticas e da literatura são campos legitimados, legitimando assim, em consequência, esse formato em detrimento dos outros suportes.

Um exemplo disso está no termo usado por Ben Schwartz (2010) para se referir às graphic novels, designando-as de lit comics, ou seja, "literary comics", o que significa, em tradução livre, "quadrinhos literários". Mais especificamente, ele chama de lit comics os quadrinhos do período coberto entre o ano 2000 até 2008, especialmente com o lançamento, pela editora Pantheon, de Jimmy Corrigan, de Chris Ware e David Boring, de Daniel Clowes. A partir desse momento, afirma o autor, os "quadrinhos literários" expandiram nos quesitos distribuição, acesso, e interesse do público. Para ele, Jimmy Corrigan, de Ware, foi fundamental para a inserção dos quadrinhos e de seus artistas nos círculos literários. Os lit comics, segundo o autor, foram profundamente formatados por Maus de Spiegelman e, por conta disso, permitiram aos quadrinhos sair das margens e ganharem cada vez mais público. Os quadrinhos mainstream, em contrapartida, foram irrelevantes para a expansão desse novo tipo de quadrinhos, pois nos anos 2000 os lit comics representavam um luxo no mercado, uma espécie de especialidade dentro da especialidade no mundo dos quadrinhos (SCHWARTZ, 2010, p. 12). Após os anos 2000, encontraram um caminho próprio a partir de um novo sistema de distribuição, estimulado principalmente pela criação/renovação de editoras voltadas a esse tipo de história em quadrinhos, de que já falamos anteriormente.

Por conta disso, acredita Schwartz (2010), os quadrinhos literários, como insiste em chamá-los, fincaram raízes na cultura norte-americana. Para o autor, um exemplo disso é a revista The New Yorker. Isso, porque a revista, que tradicionalmente publica toda semana a lista de quadrinhos de super-herói mais vendidas, abraçou essa nova estética do lit comics e convida, com frequência, seus artistas para ilustrar suas capas, 
com os destaques Ware e Clowes, além de Spiegelman, Burns, entre outros, que também publicam seus quadrinhos em algumas edições. O jornal The New York Times, em consonância, publica textos de Marjane Satrapi, Allison Bechdel, Chris Ware e Gilbert Hernandez.

Mais uma vez, entendemos a relevância das graphic novels e dos quadrinhos alternativos para o processo de legitimação cultural dos quadrinhos. Mas, afinal, por que chamá-los de "quadrinhos literários"? Podemos não concordar plenamente com as questões envolvidas no termo graphic novel, como tentamos esclarecer anteriormente, mas por que a insistência de Shwartz (2010) de chamar esses quadrinhos recentes de "literários", como se o termo pudesse, melhor do que "novela gráfica", revelar a importância e o valor destas obras e do movimento alternativo para o campo dos quadrinhos? Por que ainda é preciso, por parte de alguns, adjetivar os quadrinhos com termos provenientes de outras mídias para que eles sejam considerados de qualidade? Até mesmo Will Eisner utiliza a ideia de que as graphic novels constituem-se como literatura ao estabelecer que

O aumento e estabelecimento desse notável meio de leitura que são as histórias em quadrinhos vêm ocorrendo ao longo de sessenta anos. Das compilações das tiras publicadas nos jornais, o material das histórias em quadrinhos não demorou em evoluir para histórias maiores, até chegar às graphic novels. Esta última variante pesou muito sobre os desenhistas e roteiristas, exigindo deles uma maior sofisticação literária (EISNER, 2009, p. 03, tradução nossa ${ }^{23}$ ).

O problema, como tentamos demonstrar, é que a associação direta das histórias em quadrinhos como um produto culturalmente valorizado está profundamente ligada aos quadrinhos alternativos, que está completamente atrelado ao suporte graphic novel, que está ligado ao formato do livro e este último, em consequência, relaciona-se com um outro campo: a literatura. Se há algumas décadas as histórias em quadrinhos eram consideradas como uma "subliteratura" - como nos lembra Moacy Cirne (1970, p. 01) -,

\footnotetext{
${ }^{23}$ aumento y asentamiento de este notable medio de lectura em el formato de comic books vienen ocurriendo desde hace sesenta años. A raíz de la reconpilación de las tiras de prensa publicadas em los periódicos, el material del comic book no tardó em evolucionar hacia historias largas, hasta llegar a las novelas gráficas. Esta última variante há pesado mucho sobre el dibujante y el guionista, exigiéndoles una mayor sofisticación literaria.
} 
abaixo do nível de excelência da leitura de qualidade, hoje a palavra "literatura" é usada como adjetivo para designar obras de quadrinhos entendidas por alguns críticos e publicações como tendo um "alto grau de excelência". Um quadrinho não pode ser bom sendo apenas um quadrinho; para ser bom, ele precisa carregar consigo alguma característica, alguma nota, um leve rastro que seja de um campo que já seja legítimo, que já seja reconhecido. Afinal, reconhecer os quadrinhos por si só seria um erro; reconhecer uma obra em quadrinhos como "literária", "artística" e algumas vezes até como "cinematográfica", isso sim é dizer que a coisa é boa.

Entretanto, o campo dos quadrinhos nada tem a ver com o campo literário. Se, como afirma Paulo Ramos (2009b), os quadrinhos configuram-se como um "hipergênero", que possui dentro dele vários gêneros que podem ser veiculados em diferentes suportes editoriais e formatos, como revistas, jornais, livros e internet, então entendemos os quadrinhos como uma linguagem específica que pode conter diferentes temas e estilos. No fim das contas, portanto, os quadrinhos constituiriam um campo de produção cultural próprio. 


\section{RECONHECENDO O CAMPO DOS QUADRINHOS: A CONSOLIDAÇÃO DO PROCESSO DE LEGITIMAÇÃO CULTURAL}

Esse processo de legitimação que busca a afirmação de um produto como culturalmente valorizado e que vem tomando forma e se desenvolvendo nos últimos anos não é uma exclusividade do campo dos quadrinhos; outros produtos nascidos dentro da cultura de massa também passaram por esse mesmo processo e conseguiram, anos antes dos quadrinhos, consolidar seu espaço. O cinema talvez constitua o melhor exemplo.

Segundo Russel Nye (1987), já nos primeiros anos de sua popularização, a indústria cinematográfica sabia e se vendia como um entretenimento de massa voltado para uma audiência específica, não pretendendo nada além disso. Seus agentes entendiam, desde o início, que um filme era um empreendimento comercial, e não arte. Por isso, mesmo que fosse desejável que bons filmes fossem produzidos, era mais essencial ainda fazer filmes que fossem rentáveis. Os pioneiros desse novo meio sabiam que eles tinham que agradar o maior número de pessoas possível dando a elas o que elas queriam ver. Afinal, Hollywood era um negócio e nenhuma de suas figuras de autoridade pretendia o contrário. Nye (1987) afirma que a indústria entendeu, já na década de 1920, que o melhor que podiam fazer era tentar refletir o mais diretamente possível os interesses, valores, desejos e ilusões de seus consumidores.

Entretanto, mesmo trabalhando com todas essas restrições e normas impostas pelo mercado, foram muitos os diretores e roteiristas que exploraram novas ideias e técnicas com muita imaginação e habilidade, seguidos assim pelos atores e produtores. O ponto decisivo parece ser que o cinema entendeu que essas limitações não significavam que o que era produzido não valia a pena ser feito, que seria esteticamente feio ou pessoalmente insatisfatório. Significava apenas que seu idealizador precisava desenvolver sua obra fazendo uso de habilidades especializadas que dessem conta dessa forma de produção que, no final das contas, visa o lucro. Afinal, como nos lembra Russel Nye (1987), agradar uma grande audiência, como o faz qualquer artista parte da cultura de massa, envolve tanta habilidade quanto o artista que trabalha para uma audiência menor e "sofisticada". 
É claro que houve os críticos, assim como em todas as outras produções da cultura de massa, que consideraram o cinema como uma "escola para criminosos", ou uma "forma de entretenimento ordinária para pessoas ordinárias" (NYE, 1987, p. 373). No entanto, o reconhecimento do cinema como uma forma de arte influente, independentemente de sua produção originalmente massiva, inevitavelmente ocorreu. Como consequência, o cinema recebeu o prestígio de uma forma de arte não menos importante que as mais antigas e tradicionais, ao mesmo tempo em que sua essência de arte popular de verdade, criada para as massas e muitas vezes por elas, como um objeto cultural autenticamente democrático, foi mantida. O cinema, assim, feito para o consumo e para o lucro, tornou-se a chamada "Sétima Arte" e muitas de suas produções ganharam o status de "obras de arte" e "cult", firmando-se como uma das maiores influências culturais do mundo ocidental e objeto de verdadeira veneração.

Entretanto, essa valorização do cinema só se deu porque seus agentes entenderam que seu produto e seu público são específicos, que possuem suas próprias normas e peculiaridades. Exemplo disso é que a atuação no cinema, que no início se aproximava da atuação teatral, se distanciou desta e criou seu próprio estilo. Os roteiristas, seguindo a mesma linha, entenderam que um roteiro de um filme deveria ser pensado levando-se em consideração as peculiaridades que envolviam o novo meio, como o uso da câmera e as técnicas de corte, montagem, edição, etc., afastando-se, também, das premissas dos roteiros teatrais (NYE, 1987, p. 382). Quando os atores, roteiristas, diretores e produtores compreenderam que o cinema não é teatro filmado, assim como não é apenas uma sequência de imagens e fotografias em movimento, e passaram a produzir de acordo com suas regras e fazendo uso das técnicas que lhe são típicas e essenciais, o cinema pôde se reinventar e continuar se reinventando. Em outras palavras, é com o reconhecimento do campo cinematográfico que o mesmo pôde se firmar e se afirmar. Com isso, ao mesmo tempo em que continuam desenvolvendo produtos que agradam ao público mais geral, também produzem obras que conversam com um público mais crítico e exigente. Como consequência de sua especialização e autonomização, permitem que em um mesmo espaço seja passado o maior dos blockbusters e o mais complexo dos filmes de arte europeu.

É por isso que durante toda a pesquisa, insistimos no termo "campo" para nos referirmos às histórias em quadrinhos. Essa escolha não foi em vão. Para tentar demonstrar que os quadrinhos passaram por um processo de legitimação cultural que os 
tirou do estigma de "subcultura", era preciso entendê-los e referir-nos a eles como um meio próprio, ou seja, como uma mídia específica que alcançou essa valorização em relação às outras mídias por configurar-se como o seu próprio meio, lutando por sua autonomia e valor frente aos críticos que os desconsideravam como um produto cultural relevante, assim como o fez o cinema. Para que possamos demonstrar que existe um campo específico, iniciaremos com algumas teorias que definem o que compõe os quadrinhos.

\subsection{Do que são feitos os quadrinhos}

Para Antonio Luiz Cagnin (2014), a imagem seria o elemento característico das histórias em quadrinhos que as distingue de qualquer outra manifestação da imagem ou das narrativas. Entretanto, para o mestre, ela não havia recebido, até então, o tratamento adequado quando se fala de suas potencialidades. Enquanto muitos se preocupavam em estudar seus aspectos históricos, pictóricos, de cultura de massa, de seus personagens, autores, gênero e estilos, a imagem, o que faz de uma história em quadrinhos uma história em quadrinhos, tinha sido até então completamente esquecida. Por conta disso, o que Cagnin (2014) pretendia em sua dissertação, originalmente elaborada em 1974 que mais tarde se transformaria em um dos mais importantes livros já lançados no Brasil sobre a linguagem dos quadrinhos -, era fazer uma análise de maneira a determinar as funções do sistema narrativo e do sistema de signos linguísticos que compõem o "sistema iconográfico dos quadrinhos". Isso, porque "a maior complexidade da imagem em relação à palavra e das imagens justapostas em sequências deve levar a estudos mais objetivos e profundos, que por sua vez, esclarecerão certos aspectos psicológicos e sociológicos sugeridos pela imagem" (CAGNIN, 2014, p. 15).

Na apresentação à edição de 2014 de Os Quadrinhos, André Campos de Carvalho afirma que o grande objetivo de Cagnin no livro era o de fazer a interpretação semiótica dos signos que constituem os quadrinhos como uma forma híbrida que une imagem e texto, sendo que um elemento sempre acaba contaminando o outro (CARVALHO, 2014, p. 10). Entretanto, para Cagnin (2014) o código icônico, a imagem, deve possuir predominância sobre o código linguístico para que uma narrativa 
possa ser de fato considerada gráfica, ou seja, para que ela possa ser considerada uma história em quadrinhos. Para o pesquisador, se uma história trouxer o texto como elemento mais relevante, sem que haja a necessidade da imagem, então estaríamos falando apenas de uma história ilustrada. A imagem, assim

[...] não é aquilo que representa; não tem a transparência da palavra nem a opacidade do objeto; o meio do caminho do real e do imaginário, do documento e da ficção, ela fascina e também amedronta. Com a palavra, ou antes dela, a imagem acompanhou o homem em todas as suas necessidades, para se comunicar, para ensinar, para criticar os erros, para elevar, para destruir (CAGNIN, 2015, p. 14).

O problema é que, por muito tempo, existiu a sobrevalorização do texto em detrimento da imagem, na medida em que o primeiro assumia a ideia de uma narrativa, ao invés de ficar onde era o seu lugar, o de apenas acompanhar a imagem. Entretanto, as imagens, e especialmente os desenhos, ao longo do tempo, tomaram para si a tarefa de narrar. Assim, de acordo com Cagnin (2014, p. 30) as histórias em quadrinhos são a manifestação principal desse código e o que basicamente define sua essência.

Os quadrinhos podem, então, ser estudados sob todos os aspectos e formas. Para o autor, eles podem ser lidos a partir de uma variedade de perspectivas, como a literária, a histórica, a psicológica, a sociológica, entre outras; podem surgir em várias tipologias, como a ficção científica, as sátiras e as aventuras; possuem, em sua constituição, a imagem e o texto, o segundo podendo ser apresentado na forma de balão, legenda e onomatopeia. Nesse sentido, as histórias em quadrinhos se diferenciariam dos demais campos pela maneira como encontram formas de representação para reproduzir em suas páginas o som e o movimento: as onomatopeias, o neologismo e a ação agindo como verbo, que sugerem o movimento na história (CARVALHO, 2014, p. 10), o que faz dos quadrinhos uma linguagem única.

Além de tudo isso, existem casos em que uma história em quadrinhos simplesmente não contem texto, a não ser pelo título; são as histórias mudas, conhecidas como sans parole (CAGNIN, 2014, p. 34). Para Cagnin, inclusive, estas últimas seriam a verdadeira história em quadrinhos, ou seja, as histórias que garantem aos quadrinhos o 
nome de "arte sequencial" (CAGNIN, 2017, p. 29), uma vez que só apresentam o código icônico sem se valerem de qualquer outro, representando os momentos mais significativos da história por meio dos gestos e ações dos personagens para conceber o movimento na sequência dos quadros. "Conclui-se, então, que o texto não é essencial à história em quadrinhos, assim como o romance escrito não exige forçosamente que seja ilustrado com imagens. Os gestos das figuras, as expressões do rosto revelam a ação substituindo, com vantagem, balões e legendas" (CAGNIN, 2014, p. 35).

Para o semiólogo italiano Daniele Barbieri (1998), no livro Los lenguages del cómic, os quadrinhos são uma linguagem. Entretanto, o pesquisador não entende o termo "linguagens" como apenas os instrumentos que utilizamos para nos comunicarmos, e sim que as linguagens também são ambientes em que vivemos e que determinam fortemente o que queremos, mais além daquilo que apenas usamos para que possamos nos comunicar. Esses ambientes, ademais, não constituem universos separados, mas, isso sim, representam dentro deles inúmeros aspectos do ambiente geral da comunicação e, por isso, estão interconectados e em intensa e recíproca interação.

A linguagem para Barbieri (1998), nessa perspectiva, não é usada apenas para expressar, mas também para criar ideias. Para o autor, todas as ideias nascem de uma linguagem e, por isso, não é apenas um instrumento para disseminar ideias, mas um espaço em que nos encontramos e no qual formamos tais ideias; por conta disso, as características da linguagem têm efeito sobre nossos pensamentos. Habitar uma linguagem, dessa maneira, significa estar dentro dela, aproveitar todas as possibilidades que ela contém, assim como observar seus limites. Além disso, dizer que uma linguagem constituiu-se como um ambiente significa dizer que esta usufrui de certa autonomia quando em relação a outras linguagens. Isso, porque quando nos identificamos com uma linguagem e escolhemos fazer uso da mesma, tornamo-la a ferramenta que constitui nosso universo e que determina nossos limites. Isso não quer dizer que, escolhendo determinada linguagem, as outras automaticamente deixem de existir. Quer dizer apenas que se escolhemos e temos preferência por uma, as outras não são vistas com tanta proximidade (BARBIERI, 1998, p. 13).

É certo também, afirma Barbieri (1998), que podemos ficar em situações dúbias, incertas dentro do espectro da comunicação. Pode-se pensar, inclusive, nessas "linguagens-ambiente" como um ecossistema: cada um possuiria suas próprias regras e 
características específicas: ao mesmo tempo em que muitas regras são comuns a muitos dos outros ecossistemas e a todos os outros, existem também zonas intermediárias e de fronteiras entre dois ou mais ecossistemas diferentes, zonas nas quais se pode agir de acordo com a regra de todos os campos envolvidos. Barbieri (1998) ainda continua e diz que, assim como os ecossistemas são parte da natureza, também as linguagens são parte da comunicação em geral. Por isso, não devemos pensá-las sempre como áreas separadas e independentes, mas sim que algumas são partes de outras, resultado da fusão, do que sobrou de uma outra que se extinguiu e, parecendo-se com o que lhe deu origem, ainda assim se diferenciam. Há outras linguagens que possuem características em comum, talvez por serem herdeiras da mesma linguagem ancestral e por isso mantêm certas semelhanças. Por fim, há linguagens que adaptaram para si atributos de outras, de maneira que podem se utilizar de características que haviam sido constituídas em outro ambiente que não no próprio (BARBIERI, 1998, p. 13).

Nesse contexto, o objetivo do livro Los linguajes del cómic é fazer a ligação e a relação entre a linguagem dos quadrinhos com outras linguagens. Para isso, Barbieri (1998) distingue quatro tipos de relação entre a linguagem dos quadrinhos e as outras linguagens: a primeira é a inclusão, que quer dizer que uma linguagem faz parte de outra - no caso dos quadrinhos, eles são uma linguagem que faz parte da linguagem geral da narrativa, assim como o cinema, por exemplo, e todas as linguagens narrativas possuem características em comum; em segundo lugar está a geração, ou seja, uma linguagem é gerada pela outra - os quadrinhos são "filhos" de outras linguagens, como a ilustração e a caricatura e, por isso, compartilham das características dessas linguagens, mas ao mesmo tempo são diferentes delas em sua natureza; a terceira é a convergência, que quer dizer que duas linguagem podem convergir em determinados aspectos, ou seja, há um certo grau de "parentesco" entre algumas linguagens - os quadrinhos, no caso, possuem graus de parentesco com certas linguagens das quais eles não descendem diretamente, mas com as quais possuem antepassados em comum; a quarta, e última, relação é a adequação, ou seja, uma linguagem que se adéqua a outra - acontece quando os quadrinhos consideram mais fácil reproduzir em seu interior outra linguagem, a fim de explorar suas possibilidades expressivas, do que tentar construir possibilidades expressivas equivalentes. Os quadrinhos, de certa forma, citam outra linguagem não de maneira literal, mas criando um conjunto de características que pareçam com as da linguagem citada. (BARBIERI, 1998, 14/15) 
Barbieri (1998), então, busca descobrir quais as linguagens que envolvem a linguagem dos quadrinhos. Para tal, não trata apenas dos quadrinhos, mas também como eles compartilham com outras linguagens as relações por ele expostas. Explorar essa linguagem por meio de sua comparação e relação com as demais é um modo de introduzir o discurso da comunicação, utilizando os quadrinhos para falar do discurso geral da comunicação. Entretanto, o autor ressalta que, no final das contas, apesar de falar da relação com outras linguagens, o verdadeiro objeto do livro são as características que compõe os quadrinhos como linguagem. Para o pesquisador, procurar semelhanças e ligações entre as outras linguagens e as histórias em quadrinhos permitiria criar diferentes pontos de vista sobre suas características.

Em $O$ sistema dos quadrinhos, o pesquisador belga Thierry Groensteen (2015) entende a história em quadrinhos como linguagem, ou seja, sua abordagem não é histórica, sociológica ou econômica, mas sim enxergando os quadrinhos como um "[...] conjunto original de mecanismos produtores de sentido" (GROENSTEEN, 2015, p. 10). Por isso, os quadrinhos são entendidos pelo autor como um "sistema" e a razão para isso é, segundo Groensteen (2015), porque eles são uma combinação especialmente original de uma ou mais matérias da expressão e de um conjunto de códigos. Para o autor, então, a questão não é favorecer um dos códigos, mas o de encontrar um caminho no interior do sistema que permita entendê-lo como um todo e mostrar, assim, sua coerência. "Em resumo, nos quadrinhos, os códigos são construídos no interior de uma imagem de forma específica, que mantém a associação da imagem a uma cadeia narrativa onde as ligações se espalham pelo espaço, em co-presença" (GROENSTEEN, 2015, p. 15).

Para Groensteen (2015), as análises feitas por pesquisadores que o antecederam lhe mostraram que duas ideias gerais difundidas sobre os quadrinhos deveriam ser deixadas de lado: a primeira, de que as histórias em quadrinhos devem ter suas unidades constitutivas decompostas para serem melhor entendidas: para ele, não é abordando-as em detalhes que esse conhecimento será atingido, e sim ao abordá-las do alto, ao nível de suas articulações maiores; a segunda é a de que as histórias em quadrinhos seriam, em sua essência, um misto de texto e imagem. Entretanto, para Groensteen (2015) a imagem tem a primazia e, por isso, encontrou a necessidade, em sua pesquisa, de estabelecer uma precedência teórica que designou como "códigos visuais". 
Para o autor, a tradição logocêntrica, ao colocar o verbo em uma posição dominante em relação à imagem, trouxe duas consequências: a língua acabou sendo tomada como modelo de toda linguagem e a literatura em livro acabou considerada, quase que em todo o mundo, como o modelo de todas as formas narrativas. Esta última, acredita o autor, pode vir a tornar-se teoricamente insustentável. Isso, porque o fato de a literatura ter surgido séculos antes do cinema e dos quadrinhos, não significa dizer que ela detenha o monopólio ou o privilégio da forma narrativa. Para Groensteen (2015), desse modo, é preciso tomar cuidado para não confundir gênero narrativo com literatura, visto que estamos em um momento em que existe uma variedade de mídias que se utilizam, em maior ou menor grau, de estruturas narrativas. Aqueles, portanto, que atribuíram nos quadrinhos o mesmo valor ao texto que à imagem são aqueles que entendem que a escrita é o veículo privilegiado do gênero narrativo. Entretanto, Groensteen (2015) entende que a multiplicidade de tipos de narrativa torna essa suposição automaticamente obsoleta (GROENSTEEN, 2015, p. 17).

A insistência de Groensteen (2015) de que a imagem seja reconhecida em posição dominante no sistema dos quadrinhos não é por ela ser mais importante do que a escrita, e sim porque a maior parte da produção de sentido de uma história em quadrinhos se dá por meio da imagem. Por isso, acredita que é por meio da "artrologia" e da "espaçotopia", como ele define, que a imagem sequencial torna-se plenamente narrativa sem precisar, necessariamente, do texto. Ademais, uma característica peculiar, ligada exatamente a essa primazia da imagem, difere os quadrinhos dos demais "sistemas": suas imagens são, ao contrário de outras narrativas que têm a imagem como um de seus suportes, imóveis e silenciosas, não possuindo, logo, o mesmo poder de ilusão do cinema, por exemplo. Além disso, sua sequência não produz uma continuidade que imita o real, dando ao leitor uma narrativa repleta de intervalos que funcionam como lacunas de sentido. Entretanto, para qualquer leitor de quadrinhos o caráter fragmentado e descontínuo desses intervalos não mais existe a partir do momento em que ele está imerso na história.

Contudo, Groensteen defende que é necessário entender e reconhecer que o único alicerce ontológico dos quadrinhos é a "[...] conexão de uma pluralidade de imagens solidárias" (GROENSTEEN, 2015, p. 27). Isso quer dizer que o fundamento básico dos quadrinhos, seu princípio mais central, é o que o autor chama de "solidariedade icônica": imagens que fazem parte de uma sequência, mesmo estando 
apartadas, ao mesmo tempo em que são plásticas e semanticamente sobredeterminadas pelo fato de coexistirem. Assim, falar de quadrinhos é falar que suas imagens são diversas e de alguma forma correlacionadas. No entanto, Groensteen (2015) lembra que as histórias em quadrinhos não se constituem ou se utilizam de métodos ou técnicas particulares, criados por eles. Ao mesmo tempo, ressalta que quando em sua forma final, mesmo que com a aparência mais simples possível, são os avatares específicos de um sistema no qual suas composições e interações constituem uma totalidade inédita, complexa e única. E é por isso, explica o autor, que ele escolheu como o símbolo de sua reflexão a ideia de "sistema", pois ele

[...] define um ideal. Esse sistema dos quadrinhos será um quadro conceitual onde todas as realizações da "nona arte" podem encontrar seu lugar e serem pensadas em comparação, ao mesmo tempo nas suas diferenças e nas semelhanças comuns ao mesmo meio nesse sentido, a noção de sistema, "conjunto de coisas que se inter-relacionam" (Littré) promove o conceito fundamental de solidariedade (GROENSTEEN, 2015, p. 31).

Essa mobilização do código visual, que funciona muitas vezes em simultaneidade com o código discursivo, é o que faz dos quadrinhos uma linguagem única e inconfundível; ao usar códigos que a princípio não lhe pertencem, acabam aplicando-os de uma maneira tão específica que é impossível negar sua eficácia e especificidade em relação aos demais sistemas. Por isso, buscar a cerne do que são os quadrinhos é ter a plena certeza de não encontrar uma só resposta, mas uma profusão delas (GROENSTEEN, 2015, p. 22).

Acima estão expostos, resumidamente, o que três dos grandes estudiosos dos quadrinhos acreditam que possa definir o que é "história em quadrinhos". Antonio Luiz Cagnin, Daniele Barbieri e Thierry Groensteen podem ser de nacionalidades diferentes, terem feito suas pesquisas por meio de abordagens e metodologias diversas, e até terem escrito e publicados seus livros em épocas distintas, mas todos possuem uma coisa em comum: todos eles enxergam os quadrinhos como um meio único, que difere, em variados níveis, de qualquer outra "linguagem", "ambiente" ou "sistema". Os quadrinhos podem até guardar semelhança com outros campos; podem, até mesmo, ser 
constituídos por códigos provenientes de outros meios, mas isso não quer dizer que eles conservem a natureza e a função destes depois de adquirirem sua forma final.

Estes autores já buscaram definir o que constitui os quadrinhos com maestria. Entretanto, sabemos que, assim como todo e qualquer estudo, estes também são passíveis de crítica e suscitam debates. Exemplo disso é que para Neil Cohn (2012), enquanto a linguagem é um comportamento humano, os quadrinhos não o são. Para o autor, os quadrinhos são um objeto social resultado de dois comportamentos humanos: a escrita e o desenho. Desse modo, quadrinhos não seriam uma linguagem, como defendido por Barbieri (1998) e Groensteen (2015), e sim são escritos em uma linguagem visual, da mesma forma que os romances da literatura são escritos exclusivamente em forma de texto. Enquanto isso, para Sonia Luyten (1987), as histórias em quadrinhos são estruturadas por dois códigos de signos gráficos: a linguagem escrita e a imagem. $\mathrm{O}$ fato de terem surgido dessas duas artes aparentemente distintas, afirma a pesquisadora, não os diminui, muito pelo contrário, pois essa mistura que deu início a uma nova forma de manifestação cultural é a perfeita representação de nossa época, em que não existem fronteiras entre os meios artísticos.

Já para David Pascal (apud MUNSON, 2016, p. 11/12) as tiras - mas que podemos alongar aos quadrinhos em geral - são a junção de diálogo escrito e/ou narrativa e a ilustração pictórica. Apesar da justaposição desses dois elementos não ser nada de muito novo - era algo já utilizado pelos egípcios e chineses há milênios -, a mistura dos dois elementos formando uma estética unida a fim de criar uma expressão artística única é, sim, algo novo. Assim, mesmo que contenha os elementos da literatura e das artes visuais, a história em quadrinhos é diferente, verdadeiramente uma forma de arte e, por isso, deve ser estudada e julgada não a partir dos critérios dessas outras formas, mas por seus próprios padrões, mesmo que estes ainda precisem de definição e aperfeiçoamento.

Um último exemplo, se nos for permitido. A sarjeta, para Hillary Chute e Patrick Jagoda (2014), seria basicamente o que define os quadrinhos como essa forma narrativa única. Isso, porque os quadrinhos são um meio com uma sintaxe peculiar: entre os seus elementos básicos estão os quadros, os balões de texto, as caixas de texto e, é claro, a sarjeta, “[...] o espaço entre os quadros, divide e multiplica o tempo" e "está no cerne do funcionamento dos quadrinhos [...] É um meio que constrói e organiza o tempo e o 
espaço da página ao fazer uma montagem de uma série de momentos - transformando assim [...] tempo em espaço" (CHUTE; JAGODA, 2014, p. 05, tradução nossa) ${ }^{24}$. A sarjeta, de certa forma, funciona como uma espaço sem regras, que cabe ao leitor preencher (ou não) com significado. Por isso os quadrinhos exigem tamanho envolvimento do leitor, pois é ele, de uma forma ou de outra, que vai gerar o significado da história. Desse modo, é possível afirmar que os quadrinhos não funcionam como nenhuma outra mídia: pois a história não se apresenta diretamente e a direção e sentido a serem tomados dependem do leitor. Os quadrinhos sugerem o movimento e os leitores é que determinam a movimentação; a leitura dos quadrinhos, portanto, depende dos diferentes processos de percepção experenciados por cada indivíduo ao olhar o que as imagens na página propõem; quadrinhos são uma sucessão de vários quadros, ao mesmo tempo em que são uma composição única (CHUTE; JAGODA, 2014, p. 06), e a sarjeta tem papel fundamental nesse processo.

Levando em consideração o que foi colocado por todos esses autores, além de tantos outros, é de vital importância reconhecer o campo dos quadrinhos como autônomo e próprio, com suas próprias regras e normas, para que o debate do que constitui os quadrinhos seja possível. Isso porque, acreditamos, é só a partir do momento em que reconhecemos o campo como único, com suas próprias leis e peculiaridades, que este debate pode florescer cada dia mais, estabelecendo os quadrinhos como um objeto culturalmente valorizado e legítimo. Para tal, recorreremos ao conceito de "campo" de Pierre Bourdieu.

\subsection{O campo dos quadrinhos: ele existe e é legítimo}

Um campo, segundo Pierre Bourdieu (1992), seria um microcosmo social que detém certa autonomia, que possui suas próprias leis e normas e que se relaciona e recebe influência do espaço social mais amplo, ou seja, o macrocosmo. Entretanto, apesar de possuir suas próprias regras e normas, nenhum campo consegue escapar da imposição do macrocosmo e, por isso, sua autonomia será maior ou menor dependendo

\footnotetext{
${ }^{24}[\ldots]$ the space in between panels, divides and proliferates time is at the heart of how comics works [...] It is a medium that builds and organizes the space of the page by assembling a series of moments - thus turning $[. .$.$] time in space.$
} 
dessa influência. O campo é também um espaço de luta entre os agentes que dele fazem parte e que procuram alcançar certas posições dentro do mesmo, posições essas que são alcançadas por meio da disputa de capitais específicos - como o cultural, o social e o econômico - que são mais ou menos valorizados, dependendo das características de cada campo. Além disso, cada agente do campo possui os diferentes capitais em menor ou maior grau, o que define as posições hierárquicas que ocupam.

Todos os campos estão submetidos a um campo maior, o campo do poder, no qual ocupam uma posição dominada. Este campo de poder é, segundo Bourdieu (1992, p. 244), o espaço em que se dão as relações de força entre os agentes ou instituições que possuem o capital necessário, seja ele qual for, para ocupar posições dominantes nos diferentes campos, especialmente o capital econômico e o capital cultural. Este espaço de luta entre os que detêm o poder, ou seja, entre os detentores das espécies de capital, busca a transformação ou a conservação do valor de cada uma dessas variedades de capital.

Segundo Elaine Pereira (2015), se o campo também é um espaço de confronto, de tomada de posição e de poder, é porque todo e qualquer campo é ao mesmo tempo um campo de forças e um campo de lutas que visa conservar ou transformar esse mesmo campo perpetuamente. Formados por seus agentes, podendo ser eles pessoas ou instituições, os campos criam os espaços e estabelecem a existência desses agentes pelas relações que instituem, ou seja, é o lugar que estes ocupam na estrutura que indica suas tomadas de posição, assim como também nele são estabelecidas as diferentes relações e onde as diversas posturas assumidas pelos agentes se dão. Dentro dos campos também acontecem disputas pelo controle e legitimação dos bens que neles são produzidos (PEREIRA, 2015, p. 341).

Sendo o campo um microcosmo social que possui normas próprias e que se constitui como um palco de lutas e relações de poder, cada campo também possui seus capitais correspondentes, estes sendo movimentados, valorizados e legitimados dentro desse espaço. Por isso, afirma Pereira (2015), se um campo possui certa característica ou finalidade, determinado capital terá maior ou menor valor. Assim como o capital, cada campo também possui seu habitus específico, definido como um "sistema de disposições duráveis”. O habitus também pode ser entendido como as estruturas estruturadas que funcionam também como estruturas estruturantes. Em outras palavras, 
as estruturas são estruturantes, pois são responsáveis pela construção de práticas e representação realizadas por seus agentes; e, em contrapartida, são estruturas estruturadas na medida em que são influenciadas, recriadas e arquitetadas por esses mesmos agentes (PEREIRA, 2015, p. 344).

Por conta dessa hierarquia que se estabelece nas relações entre os diferentes tipos de capitais e aqueles que os detêm, os campos de produção cultural ocupam, inevitavelmente, uma posição dominada diante do campo de poder, isto é, por maior que seja a liberdade destes campos em relação à interferência externa, eles são atravessados pelas questões que envolvem os "campos englobantes" (BOURDIEU, 1992, p. 246), como o político e o econômico. Assim, segundo Bourdieu (1992), o status da relação de forças nessa luta depende da autonomia que o campo possui em relação ao mundo externo, ou seja, em que medida suas normas específicas conseguem impor-se em relação aos produtores dos bens culturais que detêm a posição dominante no campo de produção cultural.

Essas lutas e os objetos disputados pelos agentes definem se os mesmos serão considerados como "pretendentes" - aqueles que estão entrando no campo agora e que buscam uma posição no mesmo - ou “dominantes" - os já estabelecidos, que lutam para manter-se na posição que alcançaram. Apesar de cada campo possuir lutas de acordo com sua especificidade, elas estão presentes em todos. Assim, essas relações de força entre esses agentes, sejam indivíduos ou instituições, são as responsáveis pelas tomadas de posição, ou seja, são elas que determinam as posturas e posições dentro do campo. Com isso, os que possuem o monopólio de certo capital legitimado têm maiores possibilidades de serem ouvidos quanto a suas opiniões, assumindo assim estratégias de conservação, ao passo que os que possuem menor capital e prestígio tendem a assumir estratégias de subversão. É nessas diferenças de posição, inclusive, que as regras desse jogo são aceitas (PEREIRA, 2015, p. 348).

Dentro de um campo de produção cultural, existe a luta entre aqueles que defendem uma "arte pura" e aqueles que estão do lado da "arte comercial", o que faz com que os primeiros rechacem os segundos como verdadeiros artistas, gerando assim o que Bourdieu (1992) chama de "conflitos de definição": cada uma dessas posições procura estabelecer e impor limites ao campo que sejam favoráveis aos seus próprios interesses, o que definiria a possibilidade de vinculação verdadeira ao campo. Por isso, 
quando os que defendem um posicionamento purista da produção do seu campo e quem a ele pode pertencer estabelecem aqueles que não podem ser considerados como "verdadeiramente" artistas e, em consequência, recusam a estes suas existências enquanto artistas, buscam na verdade impor dentro do campo o seu ponto de vista como o único legítimo, como a lei fundamental e como o único viável para definir o campo (BOURDIEU, 1992, p. 253).

Essa visão do artista puro que se impõe sobre a do artista "ordinário" é exatamente o ponto que constitui o campo como tal e o que define a entrada ou não nele, isto é, ninguém pode entrar e fazer parte dele se não estiver dotado de um ponto de vista que esteja de acordo, ou que pelo menos coincida, com o ponto de vista do agente fundador e definidor do campo. As rivalidades, dessa forma, se estabelecem a partir da busca pelo monopólio da legitimidade da produção do campo específico; o monopólio de dizer com autoridade quem pode ou quem não pode ser considerado como um artista. Em outras palavras, o monopólio do "poder de consagração dos produtores ou dos produtos" (BOURDIEU, 1992, p. 253), a luta entre os dois opostos do campo de produção cultural, se dá pelo exercício do monopólio da imposição do que é ou não legítimo. Assim, segundo Bourdieu:

As lutas pelo monopólio da definição do modo de produção cultural legítimo contribuem para reproduzir continuamente a crença no jogo, o interesse pelo jogo e pelas apostas, a illusio, da qual são também o produto. Cada campo produz sua forma específica de illusio, no sentido de investimento no jogo que tira os agentes da indiferença e os inclina e dispõe a operar as distinções pertinentes do ponto de vista da lógica do campo, a distinguir o que é importante [...] Mas é igualmente verdade que certa forma de adesão ao jogo, de crença no jogo e no valor das apostas, que fazem com que o jogo valha a pena ser jogado, está no princípio do funcionamento do jogo, e que a colusão dos agentes na illusio está no fundamento da concorrência que os opõe e que constitui o próprio jogo. Em suma, o illusio é a condição do funcionamento de um jogo no que ela é também, pelo menos parcialmente, produto (BOURDIEU, 1992, p. 258).

Entretanto, existe um limite para as estratégias de subversão, pois estas podem significar uma ameaça aos agentes e ao campo. Essa "cumplicidade objetiva" (PEREIRA, 2015, p. 349) também estabelece, por exemplo, o status que uma obra passa a ter graças ao reconhecimento que recebe dentro de seu campo de produção, 
consideração que lhe outorga valor e legitimidade. O valor de uma obra, assim, é a ela atribuído a partir da crença nela depositada pelos agentes do campo, na medida em que o produtor do valor de uma obra é o próprio campo, e não o autor/criador/artista dessa obra. Ou seja: quando o campo existe, são os agentes que delegam legitimidade a uma obra.

Em outras palavras, o valor de uma obra, seja ela artística ou não, é definido pelo campo e por seus agentes, visto que o que é considerado legítimo é resultado desse jogo, ao mesmo tempo em que contribui para reproduzir a crença no jogo e em seus resultados. Os campos, desse modo, possuem a função de "fazer crer" (PEREIRA, 2015, p. 350). Se os campos de produção cultural possuem capitais específicos, então o poder simbólico de se fazer com que se acredite, como forma de dar reconhecimento e consagração a algo, é um dos pontos chave que ligam os campos de produção cultural. Assim sendo, não se deve levar em consideração apenas os produtores diretos de uma obra, mas também o grupo de agentes e instituições que delegam o valor da obra por meio da produção da crença no valor da arte como um todo, e no valor daquela obra em particular (BOURDIEU, 1993, p. 259). Em suma, para Bourdieu

O produto do valor da obra de arte não é o artista, mas o campo de produção enquanto universo de crença que produz o valor da obra de arte como fetiche ao produzir a crença no poder criador do artista. Sendo dado que a obra de arte só existe enquanto objeto simbólico dotado de valor se é conhecida e reconhecida, ou seja, socialmente instituída como obra de arte por espectadores dotados da disposição, tem por objeto não apenas a produção material da obra, mas também a produção do valor da obra, ou, o que dá no mesmo, na crença do valor da obra (BOURDIEU, 1992, p. 259).

Dadas todas essas considerações e questões que definem um campo de produção cultural sob a ótica de Pierre Bourdieu, podemos nos voltar agora para entender o porquê dos quadrinhos constituírem um campo específico, com suas próprias lutas, disputas, tomadas de posições e determinações do que é ou não é legítimo a partir da decisões tomadas pelos agentes que ocupam esse campo e que possuem determinado capital cultural. André Pereira de Carvalho (2013) defende as histórias em quadrinhos como um campo específico que, assim como ocorre com os pressupostos teórico- 
metodológicos do pensador francês, tem sua autonomia - mesmo que relativa - e cujas práticas, muitas vezes, estão relacionadas ao jogo de poder.

Assim, Carvalho (2013) retoma a noção de que a existência de um campo só é possível quando seus elementos constituem-se por regras próprias e autônomas em relação aos demais campos, ou seja, este campo, antes de se tornar autônomo, estava ligado a outro campo mais geral. Desse modo, o autor nos lembra que os quadrinhos passaram por esse exato processo: antes de se tornarem um campo autônomo, os quadrinhos eram comercializados por meio de jornais e revistas vendidos nas bancas de jornais, os eventos dos quais faziam parte eram literários, ganhando um pequeno espaço dentro deles, além de fazerem parte de grupos de trabalho acadêmicos na área de comunicação. Nesse sentido, a configuração dos quadrinhos como um campo autônomo se consolidou quando eles passaram a ter seus próprios eventos, crítica especializada, produção e comercialização próprios (como editoras, selos e lojas especializadas), além de produção, grupos de trabalho e eventos acadêmicos voltados especificamente para os quadrinhos. Em suma, os quadrinhos estabelecem-se um campo autônomo quando passam a ser os protagonistas de suas produções, e não meros coadjuvantes nas dos demais campos (CARVALHO, 2013).

Como nos lembra Bourdieu (1992), entretanto, a autonomia do campo nunca é total, e sim relativa, considerando que qualquer campo pode sofrer influência dos demais campos e também do macrocosmo, o campo de poder que engloba todos os outros. No caso dos quadrinhos, afirma Carvalho (2013), a influência pode vir tanto dos campos mais próximos, como o do cinema, da literatura, e dos jogos eletrônicos, quanto da sociedade capitalista como um todo. Todavia, por mais que o campo dos quadrinhos não possua autonomia o suficiente para rechaçar as normas impostas pela sociedade na qual está inserido, ele pode estabelecer suas próprias regras. Neste ponto, encontramos mais claramente a convergência entre a ideia de um campo dos quadrinhos, que estabelece as próprias regras e possui suas próprias características e peculiaridades, e os pressupostos de Antonio Luiz Cagnin (2014), Daniele Barbieri (1998) e Thierry Groensteen (2015) expostos anteriormente.

Waldomiro Vergueiro (2014) nos lembra, por exemplo, que foi Antonio Luiz Cagnin o primeiro a sistematizar o processo de reconhecimento dos quadrinhos como uma forma de expressão, exatamente ao diferenciá-los de outras formas narrativas 
destacando assim os elementos característicos que permitem ao leitor de uma obra criar o sentido a partir da disposição da imagem e do texto. Enquanto isso, para Barbieri (1998), fazer da linguagem dos quadrinhos a protagonista das obras que se produzem com essa linguagem representa uma conquista importante para aqueles que dela fazem uso, além da tomada de consciência da própria existência autônoma como linguagem, dando aos quadrinhos a oportunidade de emancipar-se e, assim, tomar consciência de suas próprias possibilidades. Já para Groensteen (2015), por mais que exista um gênero narrativo mais amplo, e que dentro dele existam diversas espécies narrativas, como o filme, a peça teatral e as histórias em quadrinhos, cada um propõe ao seu público um modo de exposição da história e disposição de competências próprio, que possui suas próprias especificidades e atrativos. Exemplo disso é que os quadrinhos, mesmo com mais de um século de existência, mantiveram sua popularidade exatamente por seu caráter único, que atrai seu próprio público.

Entretanto, existe uma outra questão que pode demonstrar como o campo autônomo dos quadrinhos, na visão de Pierre Bourdieu, se constitui: essa questão envolve os diferentes tipos de capital simbólico descritos pelo pensador francês. Levando-se em consideração, como coloca Bourdieu (1992), que os diferentes indivíduos ou instituições de cada campo utilizam seus diferentes graus de capital simbólico para se estabelecer e criar hierarquias dentro do campo, Carvalho (2013), explica que o capital simbólico no campo dos quadrinhos não funciona como um poder abstrato. $\mathrm{O}$ autor quer dizer que o capital simbólico, dentro do campo dos quadrinhos especificamente tem relação direta com o capital cultural em um primeiro momento, e com o capital econômico de forma secundária.

O capital cultural no campo dos quadrinhos, explica Carvalho (2013), refere-se não à qualidade artística das obras, e sim à valorização da produção artística no campo assim como coloca Bourdieu (1992) quando afirma que o valor não está na obra em si, e sim que é o campo que produz o valor da obra. São os artistas reconhecidos dentro do campo que detêm um alto capital cultural, inclusive pelo reconhecimento de sua obra. Isso não quer dizer, ressalta o autor, que um alto capital cultural seja sinônimo de qualidade artística - coisa que seria indefinível -, e sim que a obra é reconhecida dentro daquele universo porque ela é legitimada pelos agentes que dele fazem parte (CARVALHO, 2013). O capital econômico, por mais que em menor grau, também desempenha função importante no campo dos quadrinhos. Normalmente considerado, 
dentro da teoria de Bourdieu (1992), oposto ao capital cultural, o capital econômico também delega status a um artista ou obra, já que as suas vendas significam a aceitação por parte do público em geral, o que influencia no reconhecimento do artista.

Dado esse jogo de reconhecimento e legitimação de que fala Bourdieu (1992), jogo esse em que certos indivíduos e instituições ganham maior visibilidade, respeito e importância dentro do campo do que outros, a maioria não consegue alcançar o status que gostaria pelo fato do campo possuir espaço e configuração limitados. Essa distinção é criada entre aqueles que já estão nas posições dominantes e os que aspiram a tais condições. Entretanto, é importante lembrar, a posição que cada um ocupa nada tem a ver com a qualidade de seu trabalho, e sim com o grau dos diferentes capitais que possuem, levando assim à hierarquização do campo. Carvalho (2013) ainda lembra que as posições ocupadas por cada um não são dadas naturalmente, e sim construídas social e historicamente e, por isso, por mais que alguns agentes ajam de acordo com o que deve ser feito para alcançar determinada posição, as forças que regem o campo é que irão beneficiar ou retardar o avanço.

Nesse contexto, "a história do campo dos quadrinhos é formada por aqueles que alcançaram as posições superiores, e nela se firmaram como exemplos a serem seguidos" (CARVALHO, 2013). Exemplo disso, podemos comentar, são as graphic novels. Dentro de um meio que sempre buscou legitimação cultural, esse suporte, ao impulsionar a valorização do campo, tornou-se privilegiado dentro do mesmo, ocupando as posições dominantes visto o alto grau de capital cultural que possui. Além dos suportes, os gêneros que constituem o campo das histórias em quadrinhos também fazem parte desse jogo de poder: enquanto as autobiografias, por exemplo, possuem um alto grau de capital cultural, o gênero dos super-heróis foi, por muito tempo, taxado e visto apenas como um entretenimento barato e sem conteúdo.

Por sinal, a discussão sobre "gênero", quando se fala em quadrinhos, também já criou muita controvérsia. Por muito tempo, foi difundida a ideia de que quadrinhos representavam um gênero literário; nos últimos anos, as graphic novels receberam a alcunha de gênero, ao invés de serem vistas, como tentamos demonstrar, como um suporte editorial que pode ser usado para contar histórias de diferentes gêneros. Segundo Wolk (2007), existe um motivo para essa confusão. Até 20 anos atrás, o modo como quase todo mundo experienciava o meio estava ligado intimamente a uma série de 
gêneros, que era o que fazia dinheiro para as editoras: os quadrinhos de horror, romance, ficção científica ou de crime, tinham, de certa forma, uma fórmula e códigos próprios, o que poderia confundir o leitor. Além disso, o gênero dos super-heróis tomou conta do mercado dos quadrinhos tão fortemente que, para muitos, "super-herói" passou a ser sinônimo de "história em quadrinhos".

Partindo das premissas de Maingueneau, Paulo Ramos (2009b) define esse campo dos quadrinhos como um "hipergênero", ou seja, as histórias em quadrinhos são um hipergênero que abrigam, dentro de si, uma gama de diferentes gêneros autônomos, mas que são unidos por alguns elementos em comum (RAMOS, 2009b, p. 357). Se as histórias em quadrinhos são um hipergênero, quer dizer que elas carregam consigo características específicas que podem aparecer como elementos em comum em uma variedade de gêneros autônomos que constituem o hipergênero, como, por exemplo, o uso de uma linguagem própria com determinados recursos (como o uso de balões e onomatopeias); predominação do tipo textual narrativo; pode ter personagens, sejam fixos ou não; a narrativa pode estar em um ou mais quadrinhos e pode variar de acordo com o gênero abordado, entre outras.

Esses elementos, afirma Ramos (2009b), revelam ao leitor, de antemão, o que o espera, ou seja, “[...] antecipam informações genéricas ao leitor e ajudam no processo de identificação e leitura dos diferentes gêneros que compartilham tais características" (RAMOS, 2009b, p. 362). Partindo dessa ideia, Ramos afirma que as histórias em quadrinhos são um grande rótulo, que une características variadas comuns e que abriga uma variedade de gêneros utilizados "[...] para compor um texto tendencialmente narrativo dentro de um contexto sociolinguístico interacional” (RAMOS, 2011).

Outro acontecimento que demonstra como os quadrinhos são um campo de produção específico e não um gênero, é que uma mesma obra pode pertencer a dois gêneros ao mesmo tempo, da mesma maneira que um gênero não se limita a apenas um campo. Segundo Catharine Abell (2012), não é possível estabelecer com clareza a característica que define ou não uma obra como pertencente a um determinado gênero. $\mathrm{Na}$ verdade, afirma a autora, uma variedade de diferentes tipos de características determina o gênero a qual certa obra pertence. $O$ gênero, assim, seria estabelecido não apenas pelo conteúdo da obra, mas também por sua estrutura, e até mesmo pelos efeitos 
que têm sobre o público. Por isso, determinadas propriedades podem ser relevantes para determinar um gênero em alguns casos, mas não em outros.

Dessa forma, uma alternativa para se explicar o que determina o pertencimento de uma obra a determinado gênero, propõe Abell (2012), seria entender que uma única obra pode pertencer a mais de um gênero. Por exemplo: uma história em quadrinhos pode ser considerada um romance e ao mesmo tempo uma aventura, pertencendo a ambos os gêneros ao mesmo tempo, mas sem deixar de ser uma história em quadrinhos. Essa constatação, inclusive, permite perceber que alguns gêneros incorporam obras que pertencem a uma variedade de mídias: o romance e a aventura citados acima não são gêneros exclusivos dos quadrinhos, podendo fazer parte e funcionar dentro de outros campos, como o cinema, a televisão e a literatura. Além do mais, para se estabelecer adequadamente os gêneros, defende Abell (2012), é preciso também distinguir as categorias de gênero de outras variedades de categorias em que as obras podem ser classificadas, como o contexto histórico e o estilo. Um contexto histórico, assim, não é exclusivo de um campo em particular, ou seja, diferentes campos podem produzir suas próprias obras tendo o mesmo contexto histórico como pano de fundo, o que não significa que estes trabalhos provêm do mesmo campo.

Dado tudo isso, podemos dizer, com certa segurança, que as histórias em quadrinhos não são um gênero da literatura, ou um braço do cinema, ou um filho ilegítimo das artes plásticas. Mesmo que os quadrinhos possam conter ou ter herdado características de outros campos, o produto final nada tem a ver com eles. E é por isso que defendemos que é só a partir do entendimento de que existe um campo de produção cultural dos quadrinhos que, acreditamos, os quadrinhos cristalizarão esse processo de legitimação pelo qual vêm passando. Com essa cristalização, deslizes e confusões, como chamar os quadrinhos de um "gênero", ou necessitar de adjetivações como "literário" e "cinematográfico" para considerar uma obra como boa seriam evitados. Apesar de falar especificamente do campo literário, a análise estrutural da narrativa desenvolvida por Tzvetan Todorov (2003) ajuda a entender a importância de se pensar em um campo dos quadrinhos.

Para se fazer uma análise estrutural da narrativa é preciso, antes de tudo, opor duas instâncias em relação à literatura, sendo elas o que Todorov (2003) chama de atitude teórica e atitude descritiva. A análise estrutural, entretanto, será sempre de 
caráter teórico, considerando que a finalidade do estudo nunca será descritiva em relação a uma obra. Esta, segundo o autor, seria a "manifestação de uma estrutura abstrata, da qual ela é apenas umas das realizações possíveis” (TODOROV, 2003, p. 80). Portanto, o principal objetivo da análise estrutural é o de entender a estrutura dessa narrativa. O que Todorov (2003) pretendeu ao iniciar um estudo sobre a análise estrutural da narrativa foi sugerir que houvesse uma teoria da estrutura do discurso literário, procurando entender seu funcionamento. Para tal, haveria a necessidade de pesquisa empírica a fim de determinar o que uma obra tem em comum com algumas (em relação a gêneros, escolas literárias, época, entre outros) e com todas as outras (o que seria, então, uma teoria da literatura).

Todavia, afirma Todorov (2003), mesmo que buscar o entendimento de uma obra literária por meio das premissas acima elencadas não signifique negar a relação da literatura com outros campos de conhecimento, como a sociologia e a filosofia, é preciso antes estabelecer uma "ordem hierárquica", ou seja, "a literatura deve ser compreendida na sua especificidade, como literatura, antes de se procurar estabelecer sua relação com algo diferente dela mesma” (TODOROV, 2003, p. 81).

Nesse sentido, a ideia de Todorov (2003) de que os diferentes espaços de conhecimento devem ser entendidos em sua individualidade, em si mesmos antes de comparados a outros espaços se encaixa perfeitamente na noção de que as histórias em quadrinhos necessitam que seu campo seja afirmado como autônomo. Isso, porque por mais que um estudo que compare dois campos seja possível, e por vezes até mesmo necessário - comparando entre eles, por exemplo, gêneros (romance, policial, etc) e até mesmo períodos (o que foi produzido, na literatura e nos quadrinhos, no período da contracultura da década de 1960; ou a adaptação de quadrinhos para o cinema e como essa adaptação se comporta dentro do novo formato e da nova linguagem) -, é preciso, antes de tudo, entender os quadrinhos em sua especificidade e entre obras do mesmo tipo antes de tentar entendê-las dentro de um campo do qual não fazem parte. Com essa percepção, os erros e deslizes cometidos seriam evitados. Douglas Wolk (2007) resume bem esse sentimento ao dizer que

Existe um problema com a forma como muitas pessoas falam sobre os quadrinhos: é muito difícil falar deles como quadrinhos. Um erro muito comum dos críticos da cultura é se direcionar aos quadrinhos 
chamando-os de "o gênero dos quadrinhos". Assim como os quadrinistas e seus admiradores de longa data estão cansados de explicar, quadrinhos não são um gênero; eles são uma mídia. Faroestes, romances da realeza, noir: estes são gêneros - tipos de histórias com categorias de assuntos específicos e convenções em seu conteúdo e apresentação. (Histórias sobre super-heróis são um gênero também). Prosa ficcional, escultura, vídeo: assim como os quadrinhos, são mídias - formas de expressão que têm algumas ou nenhuma regra em relação ao seu conteúdo, ao contrário das muitas regras impostas a eles por sua forma (WOLK, 2007, p. 11, tradução nossa) ${ }^{25}$.

Podemos extrair mais um exemplo dos escritos de Wolk (2007). O autor nos conta sobre um relato feito por Gloria Emerson na revista The Nation. Ela conta que nunca foi leitora de histórias em quadrinhos, mas resolveu dar uma chance a Persepolis, de Marjane Satrapi. Ao ler a história, ficou tão impressionada com a qualidade da arte e da narrativa que não conseguiu classificá-la como uma "história em quadrinhos", mas sim como uma "memória gráfica". Wolk (2007) acha isso tão absurdo que lembra que se alguém falasse que o filme Siriana é tão bom que não pode ser considerado um filme, e sim uma "narrativa cinematográfica", todos achariam estranho.

Com esse exemplo, Wolk (2007) demonstra como a confusão gênero/mídia é uma questão de ignorância, ao passo que a ideia de que se algo é bom e profundo simplesmente não pode ser considerado como um quadrinho é apenas um caso de esnobismo e soberba. Entretanto, lembra o autor, o maior erro linguístico usado para se referir aos quadrinhos é tratá-los como se fossem particularmente estranhos ou produtos de uma falha, exemplos de uma outra mídia combinada. Os que são considerados por muitos como "bons quadrinhos" são muitas vezes descritos como sendo "cinematográficos", quando têm aspectos familiares à linguagem cinematográfica, ou "literários", quando têm características de romances literários. Como afirmamos nas sessões anteriores, as diferentes mídias acabaram se transformando em adjetivos quando

\footnotetext{
${ }^{25}$ There's a problem with the way a lot of people talk about comics: it's very had to talk about them as comics. One numbingly common mistake in the way culture critics adress them is invoque "the comik book genre." As cartoonists and their longtime admirers are getting a little tired of explaining, comics are not a genre; they're a medium. Westerns, Regency romances, film noir: those are genres - kinds of storir with specific categories of subjects and conventions for their contents and presentation. (Stories about superheroes are a genre, too) Prose fiction, sculpture, vídeo: those, like comics, are media forms of expression. That have few or no rules regarding their contents other than the very broad ones imposed on them by their form.
} 
usadas para falar sobre os quadrinhos. Consideramos isso mais como um insulto ao meio do que como um elogio, pois usá-los como algo que tenta exaltar ou enaltecer deixa implícito que os quadrinhos como uma forma ambicionam ser cinema ou literatura (WOLK, 2007, p. 13).

Para Robert Petersen (2011), os quadrinhos permanecem no "limbo" entre arte e literatura, o que faz com que o campo se debata quanto ao estabelecimento de uma terminologia e teoria próprias e distintas que possam melhor definir seu funcionamento. Uma das estratégias utilizadas para estabelecer e solidificar o campo foi o de denominalo pelo termo "narrativa gráfica". "Narrativa gráfica", segundo Petersen (2011), pode ser usado para designar vários processos correspondestes às artes sequenciais, como os quadrinhos. Entretanto, este termo não designa (ou não deveria designar) os filmes e as animações, pois os processos artísticos e as qualidades das narrativas gráficas são diferentes. Em comparação com os desenhos animados, por exemplo, apesar de possuírem algumas semelhanças visuais, as narrativas gráficas usam códigos visuais diferentes para contar a história, assim como são distintas a forma em que o público experimenta ambas as formas narrativas.

Entretanto, para Petersen (2011), o ritmo de leitura da história se assemelha mais ao ritmo de leitura de um livro de literatura. Isso, porque em ambos os casos, o ritmo é ditado pelo próprio leitor, diferente dos desenhos animados ou dos filmes, que têm seu ritmo ditado pelo suporte que os transmite. As semelhanças entre a leitura de uma história em quadrinhos e de um livro de literatura, entretanto, acabam aí. Se elas se assemelham quanto ao ritmo, isso não as faz, de maneira alguma, iguais. E ressaltamos isso não apenas pelas diferenças na forma de produção e composição dos dois tipos de linguagem, mas também quanto ao seu consumo e recepção: enquanto o livro literário é lido na sequência proposta pelo autor, o leitor de quadrinhos nem sempre lê uma história em quadrinhos de maneira linear (PETERSEN, 2011, p. xiv).

Se quadrinhos não são literatura, tampouco são livros ilustrados, como por muito tempo se disseminou. Como nos lembra Thomas Wartenberg (2012), as histórias em quadrinhos têm como um de seus princípios básicos, na maioria dos casos, priorizar igualmente o texto e a imagem, já que um não funciona, no geral, independentemente do outro. Nesse sentido, o que faz da imagem uma "ilustração" nos livros ilustrados é que ela é direta, ou seja, está necessariamente e diretamente relacionada com o que ela 
ilustra. Em outras palavras, a ilustração seria o que o texto está informando em forma de desenho, e não um complemento ao mesmo. A ilustração, dessa forma, é uma representação fiel do que diz o texto a qual a ilustração ilustra, em uma relação assimétrica entre texto e imagem, em que a imagem será subordinada ao texto. Há também, é claro, livros ilustrados em que suas imagens estão menos subordinadas ao texto do que outras, como no caso de Alice no País das Maravilhas, por exemplo. Nele, a história é contada pelos dois signos, o texto e a imagem. Mesmo que a última ainda seja uma ilustração da história escrita e dependente do texto que a precede, ainda assim tem um papel mais fundamental na obra do que outros livros ilustrados.

Figura 21 - Como a imagem e o texto funcionam em Alice no país das maravilhas

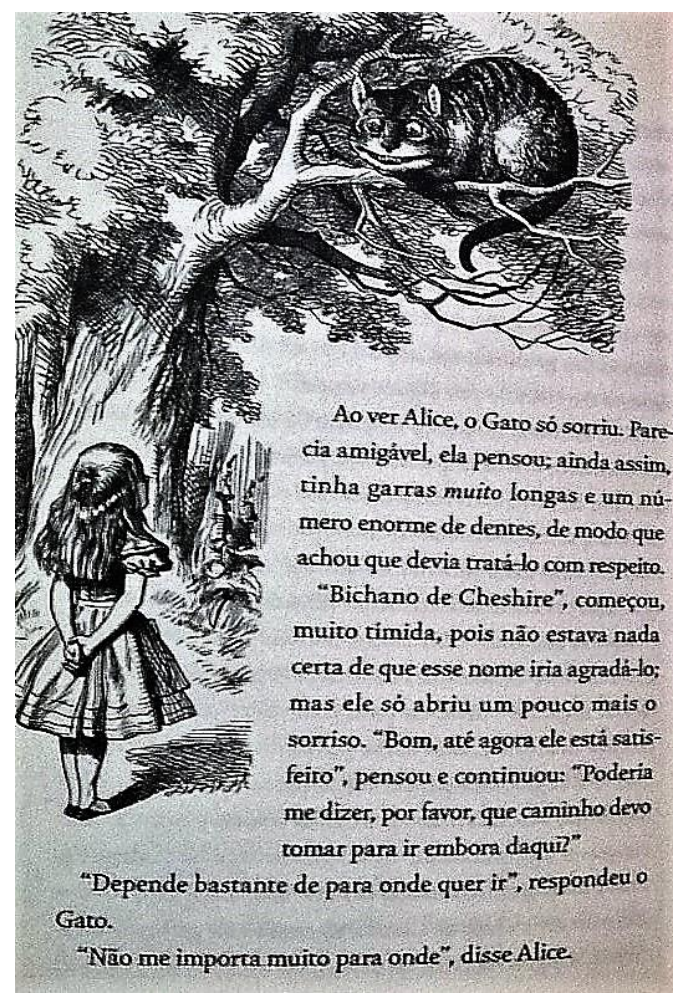

Fonte: Carroll (2009)

Dadas as questões acima, podemos notar que, diferentemente delas, os quadrinhos não são ilustração de uma história já escrita, pois as imagens nos quadrinhos não são livres da obrigatoriedade que governa as ilustrações (WARTENBERG, 2012). Sendo uma das constituições básicas do campo os quadros, então os quadrinhos são 
histórias constituídas de um ou mais quadros em que a imagem e o texto - na maioria das vezes - contribuem igualmente para a narrativa. Assim, por mais que de fato existam histórias em que alguns quadros, páginas inteiras e até mesmo toda a história não contenham texto - as sans parole de que fala Cagnin (2014) -, quando os dois estão juntos em uma história, nenhum tem mais importância do que o outro; caso contrário, não é uma história em quadrinhos.

Outro erro comum é o de considerar os quadrinhos como o "filho ilegítimo" das artes plásticas. Entretanto, muitas são as distinções entre os campos para que os quadrinhos cheguem a receber esse título. Em primeiro lugar, porque o campo das grandes artes e o campo dos quadrinhos fazem parte de sistemas econômicos distintos, pelo simples fato de serem vendidos e consumidos de maneiras completamente diferentes (SJÅSTAD, 2015). Mesmo se levarmos em consideração, por exemplo, que a produção em massa dos quadrinhos não necessariamente signifique que seu público alvo sejam as massas, a técnica de produção dos quadrinhos é uma das características que os definem: se produzidos por meio de outra técnica, seriam definidos de forma diferente, e por isso é importante apontar que o processo de impressão é uma condição necessária, dadas as devidas exceções, para definir o que é uma história em quadrinhos. A forma de produção, inclusive, determina a formalidade técnica, como são feitos, como devem ser lidos e por meio de qual suporte (jornais, revistas ou livros, como no caso das graphic novels), formalidade técnica essa que pouco se assemelha com a das artes plásticas.

Por sinal, uma das grandes discussões que perseguem os quadrinhos, nesse momento em que eles passam por um processo de legitimação, é considerá-los ou não como arte. Para SJÅSTAD (2015), o discurso sobre o mundo das artes, que para alguns pode soar antiquado e obsoleto, ainda é uma parte integrante da recepção e aceitação dos quadrinhos. É por isso que, segundo o autor, a questão que ronda esse universo, se quadrinhos deveriam ou não deveriam possuir o status de arte, é tão comumente discutida:

Embora as barreiras entre os vários meios artísticos e mundos da arte pareçam estar se confundindo em uma era pós-moderna e pós-punk, ainda parece que os quadrinhos são quadrinhos e arte culta é arte culta. Eles desenvolveram uma relação interessante, alimentando um 
ao outro com imagens e ideias. Os quadrinhos nunca poderão ser o mesmo que a literatura ou que as artes; eles representam seu próprio mundo e estão em constante diálogo com os demais. A diferença agora parece ser que os quadrinhos agora são enxergados como parte de um sistema das artes, e não apenas pulp fiction. (SJÅSTAD, 2015, p. 16 , tradução nossa) ${ }^{26}$

Entretanto, os quadrinhos podem não ser exatamente "arte", como se pensam as artes plásticas, mas muitos o consideram como uma "forma de arte". Isso acontece quando, a partir da década de 1980, as histórias em quadrinhos passaram a ser denominadas de "9a arte". (VERGUEIRO, 2009, p. 29). Os quadrinhos, então, passaram a fazer parte do conjunto formado pelas demais artes consideradas mais tradicionais, no caso a música, a dança, a pintura, a escultura, a literatura e o teatro. Mais tarde, o cinema e a fotografia (respectivamente, as " $7^{\mathrm{a}}$ e $8^{\mathrm{a}}$ artes") passaram a integrar o grupo, seguidos pelos quadrinhos. Exemplo dessa nova forma de se enxergar os quadrinhos está na introdução ao livro The Art of Comics: a Philosophical Approach, de Aaron Meskin e Roy Cook (2012). Nele, os autores acreditam que quadrinhos sejam uma forma de arte, o que não quer dizer, entretanto, que todas os quadrinhos sejam "obras de arte". Um exemplo, eles pontuam, é o cinema: apesar de considerado por muitos como uma forma de arte, nem todos os filmes podem ser considerados obras de artes - e isso vale também para a fotografia, a pintura, etc. E o mesmo vale para os quadrinhos: mesmo considerando algumas publicações como obras de arte, nem todas o são. Desse modo, assim como o cinema, a literatura, as artes plásticas e a fotografia, as histórias em quadrinhos representam uma categoria significante de arte (MESKIN; COOK, 2012), ou seja, tanto críticos quanto o público em geral deveriam apreciar, avaliar e interpretar os quadrinhos como "quadrinhos" e ponto.

Podemos ter problemas com a designação de algo bom, em qualquer campo, como "obra de arte", mas a simples noção de que qualquer mídia pode produzir tanto obras boas quanto ruins, demonstra como cada um deles constitui seu próprio campo, assim como os quadrinhos que, segundo Art Spiegelman, "como qualquer outro meio,

\footnotetext{
${ }^{26}$ Although the boudaries between the various artistic mediums and worlds of art seem to be blurring in a Postmodern, post-Punk era, it still looks as if comics are comics and fine art is fine art. They carry on na interesting relationship, feeding each other with images and ideas. Comics dialogue with the other worlds. The difference now seems to be that comics are looked upon as part of the system of the arts, and not merely pulp ficiton.
} 
seu valor é neutro. Existem muitos romances e novelas ruins, e zilhões de quadrinhos ruins. Mas nas mãos de alguém que saiba usar seu meio, grandes coisas podem acontecer. Bons quadrinhos deixam uma impressão que dura para sempre."(tradução nossa $)^{27}$

No entanto, não consideramos um erro ou uma abominação que um quadrinho faça uso de aspectos de outras mídias para construir sua história. Existem quadrinhos que se utilizam de dispositivos cinematográficos, por exemplo, para contar uma história, assim como outros se utilizam de termos e até passagens de obras da literatura para desenvolver sua narrativa, assim como de elementos das artes plásticas. Entretanto, uma história em quadrinhos não é boa porque usou recursos cinematográficos, artísticos ou literários, é apenas uma boa obra de quadrinhos que se utilizou desses recursos.

O próprio Will Eisner, como já discutimos aqui, se referia aos quadrinhos como uma "forma literária". É claro que as histórias em quadrinhos possuem certa semelhança com a literatura, afinal, muitas usam palavras, são impressas em livros e são narrativas; entretanto, quadrinhos são tão literatura quanto a televisão ou o teatro. Em suma, o fato de guardarem certa semelhança com qualquer outra mídia não os faz um exemplar dessa mídia. Quadrinhos não são artes plásticas, não são literatura, não são cinema; quadrinhos não são um gênero literário, um storyboard cinematográfico ou um livro ilustrado. Como diria Paulo Ramos (2009a), "quadrinhos são quadrinhos”. Eles são “eles mesmos”, sua própria mídia, pois contêm seus próprios mecanismos, inovações, clichês, gêneros e armadilhas. O primeiro passo para apreciar os quadrinhos em sua totalidade é exatamente reconhecer isso.

\footnotetext{
${ }^{27}$ Like any other medium, it's "value-neutral". There've been lots of rotten novels and paintings, and zillions of rotten comics. But in the hands of someone who knows how to use their medium, great things can happen. Good comics make an impression that lasts forever. Disponível em: http://www.indiebound.org/author-interviews/spiegelmanart. Acesso em 31 jan. 2016
} 


\section{CONSIDERAÇÕES FINAIS}

A palavra "cultura", como pudemos notar, é ao mesmo tempo ampla demais e restrita demais. Enquanto seu significado antropológico abrange basicamente tudo desde como nos vestimos até as comidas que comemos -, o sentido estético da palavra que se firmou a partir do século XIX inclui a música clássica, mas não a fícção científica (EAGLETON, 2011, p. 51), ou seja, aquilo que pertence à cultura de massa. A desconsideração dessas produções como "cultura" está no fato de que elas deixam de ser culturais porque não são consideradas práticas significativas. Isso, porque se a cultura, no sentido mais estrito do termo, acabou se configurando como um fato aristocrático, de acesso limitado a apenas um grupo privilegiado (WILLIAMS, 2011) e, como consequência, usada para legitimar o poder e como instrumento de dominação ou seja, usada como ideologia, nos termos de Thompson (1995) e como ferramenta de distinção, sob a ótica de Bourdieu (2007) -, as produções de uma indústria que não atende às exigências de uma pequena elite dominante, que enxerga que o seu modo de vida e suas percepções são as únicas verdadeiras e, por isso, universais, devem ser ignoradas e desdenhadas. Como produto da cultura de massa, as histórias em quadrinhos também foram, por décadas, ignoradas como um produto cultural importante.

Entretanto, as atitudes em relação aos quadrinhos têm se modificado ao longo de um grande processo, acreditamos, histórico. As temáticas e formatos mais tradicionais ainda constituem um mercado forte, enquanto gêneros que surgiram nas últimas décadas, como as coberturas jornalísticas, os biografias e os romances geraram e continuam a gerar novos interesses na mídia, inclusive levando a reconsiderações sobre esses mesmo formatos mais tradicionais das histórias em quadrinhos. Visto que, como buscamos demonstrar durante a pesquisa, as barreiras levantadas por aqueles que defendiam que produtos advindos de certos modos de produção não poderiam ser chamados de "cultura" parecem estar se dissolvendo, dando aos quadrinhos todas as possibilidades e ferramentas para que seus artistas mostrem todo o potencial do meio.

Apesar da queda nas vendas no final do século XX e início do século XXI, as histórias em quadrinhos parecem, cada vez mais, modificar o desdém cultural normalmente atribuído a elas e marcar sua presença como uma forma de arte expressiva 
no mundo contemporâneo. E isso vem ocorrendo não só pelo fato de que os quadrinhos têm recebido maior atenção por parte da crítica ao surgirem, nas últimas décadas, muitos artistas que têm estendido as noções do que significa uma história em quadrinhos, voltando seus trabalhos para temas mais profundos e que, até alguns anos atrás, não eram associados aos quadrinhos; mas também porque os quadrinhos começaram, assim como o fez o cinema há cinco décadas, a se reconhecer como um campo de produção cultural próprio, com suas próprias regras, armadilhas, tecnologias, forma de produção e comercialização.

A fusão entre bons artistas e boas críticas iniciada ainda na década de 1960 dentro do campo funcionou como uma ferramenta para acabar com anos de uma visão negativa e de marginalização cultural que por tanto tempo arrastou o nome dos quadrinhos para a lama. À medida que a cultura moderna passa cada vez mais a ser visual, as histórias em quadrinhos acabam se tornando uma forma narrativa cada vez mais atraente e o potencial do meio, que antes parecia limitado pela barreira entre a alta e a baixa culturas, recebendo apenas desdém e desprezo do público em geral, hoje é limitado apenas pela criatividade do artista que se arrisca dentro dele (BONGCO, 2000, p. xvi), afinal, "as mídias são tão ricas quanto os artistas que nela trabalham" (SPIEGELMAN, apud BONGCO, 2000, p. xvi, tradução nossa ${ }^{28}$ ). Nesse sentido, é de capital importância ressaltar, como explanamos durante este estudo, que é só a partir da valorização dos quadrinhos iniciada na década de 1960, ou seja, é só a partir da reavaliação e enaltecimento do meio como um todo, alcançados com as conquistas do movimento intelectual europeu e do movimento underground norte-americano, seguidos pela publicação de Maus e a explosão da produção e consumo das graphic novels, que os quadrinhos puderam superar o preconceito e se reinventar.

Entretanto, para alguns observadores é melhor não nos empolgarmos com esse novo momento de aceitação e legitimação dos quadrinhos, sobretudo se levarmos em consideração que a virada dos quadrinhos também se deu a partir da publicação da "tríade" de 1986. Batman: o cavaleiro das Trevas, de Frank Miller, Watchmen, de Alan Moore e Dave Gibbons e, especialmente, Maus, de Art Spiegelman, foram essenciais para a guinada que os quadrinhos deram no que diz respeito à valorização do campo. Contudo, para Paul Gravett (2010), não podemos exagerar quanto às expectativas para o

\footnotetext{
${ }^{28}$ All media are as rich as the artists working inside them.
} 
meio baseando-nos apenas nessa revolução iniciada em 1986. Brian Doherty (2010) compartilha da mesma visão ao afirmar que o entendimento de que um punhado de obras seriam as responsáveis pela reavaliação do meio daria a entender que os quadrinhos se conectam com uma audiência "respeitável" apenas ocasionalmente, como num fenômeno único que nada diz sobre a aceitação do meio como um todo (DOHERTY, 2010, p. 26).

Para Gravett (2010) e Doherty (2010) algumas obras específicas têm sim a capacidade de serem consideradas obras de arte, mas isso não implica que o reconhecimento destes trabalhos no mundo dos quadrinhos signifique necessariamente uma elevação no status do meio como um todo. Bart Beaty (2012) sanciona esse questionamento ao colocar que se de fato os quadrinhos estão prontos para aceitação do público, essa aceitação se dá primariamente a partir do sucesso de obras e autores específicos. Então fica a dúvida: será que foram os critérios de julgamento que mudaram no período pós-moderno, ou foram os artistas dos quadrinhos que finalmente passaram a criar obras que alcançam os critérios de grandeza exigidos? (BEATY, 2012, p. 102)

Concordamos em parte com essas premissas. Afinal, como expusemos na pesquisa, parece que, para certos artistas, especialmente aqueles que publicam graphic novels, atingir a consagração, em maior ou menor escala, significa ir no sentido oposto aos dos quadrinhos mainstream, o que demonstra que apenas uma parcela do que é produzido, um punhado de "obras-primas", são bem-vindas dentro do espaço da cultura legítima, e não o campo como um todo. Entretanto, assim como também tentamos demonstrar durante este estudo, tudo isso faz parte de um processo e, como em qualquer outra instância, processos envolvem "fases". Então, os movimentos da década de 1960, assim como a publicação de Maus e a explosão dos quadrinhos alternativos e seu formato de graphic novel são as fases que permitiram que o processo de legitimação cultural dos quadrinhos fosse possível.

Todas essas fases, incluindo esse "punhado" de quadrinhos altamente elogiados das últimas três décadas, ao demonstrarem que o campo pode transcender as limitações de suas formas e temas, permitiram a abertura de um caminho que, mesmo que ainda não completamente concretizado, levaria os quadrinhos a virarem a página e se prepararem para a aceitação plena. Assim, o crescimento da valorização dos quadrinhos 
que ocorreu entre as décadas de 1980 e 1990 com a publicação da "tríade", e mais fortemente com Maus, ajudou a renovar a apreciação dos quadrinhos como um todo, dando início ao entendimento deles como um campo de produção importante. Dito isso, à medida que cada vez mais trabalhos chegam a esse nível de aceitação, é possível dizer que as regras do debate têm mudado tanto que os quadrinhos, antes considerados como maléficos, se transformaram em um tema de discussão legítimo da cultura contemporânea. Então, parece claro que esse crescimento no reconhecimento de trabalhos em particular tem sim o efeito de elevar o status de todo o campo.

Afinal, é por conta desse reconhecimento que os quadrinhos vêm ganhando cada vez mais adeptos ao dar ao leitor a possibilidade de consumir da mais tradicional história de super-heróis ao mais intricado relato confessional de um quadrinista; os quadrinhos deixaram de fazer parte de eventos culturais voltados para a literatura e congressos acadêmicos da área de comunicação para criar seus próprios eventos e congressos; surgiu uma grande quantidade de publicações especializadas em quadrinhos nas últimas décadas, assim como aconteceu com as publicações voltadas ao cinema; com essa nova visão sobre o meio, espaços que antes se recusavam a receber e a enxergar a história em quadrinhos como um meio importante para a disseminação de conhecimento e valores culturais, começam a rever seus conceitos.

Assim, os quadrinhos passaram a ser considerados como um poderoso e sofisticado meio, tão importante quanto qualquer outro. A aceitação e o entendimento dos quadrinhos como um campo de produção cultural legítimo acabou por transformar esse "processo" em algo cíclico: a valorização do objeto valorizou o campo, o que consequentemente valorizou o objeto. E é por isso que ao longo de toda a pesquisa buscamos mostrar como as relações que os quadrinhos mantinham/mantêm com o social, o econômico e o político os classificaram, qualificaram e determinaram culturalmente ao longo de todo o século XX: essa relação complexa que os quadrinhos mantêm com a sociedade já determina sua constituição como um campo de produção cultural específico. Dessa forma, por mais que a noção dos quadrinhos como um campo pareça ainda não ter se solidificado por completo, se continuarmos a persistir nesse reconhecimento isso se tornará uma realidade. Isso, porque discutir os quadrinhos em sua especificidade se torna muito mais fácil e efetivo; ao não termos de compará-los com algo que nada tem a ver com ele, o campo se estabeleceria não só cultural, mas academicamente. 
Essa percepção que, de início, parece tão simples e óbvia, foi por muito tempo ignorada quase por completo, e por isso a nossa insistência de reconhecê-los como um campo de produção cultural próprio não é em vão. Entretanto, sabemos que delimitar o campo não é fácil. São muitas as teorias que buscam definir o que são os quadrinhos, aonde e quando foram inventados, quais suas aplicações nos espaços culturais e educacionais. Os próprios nomes dados ao meio nos diferentes países, como comic books, bande dessineé e fumetti, já complicam bastante o estabelecimento do que significa ser um quadrinho. Mas talvez esse seja o melhor motivo para se reconhecer e cristalizar o campo dos quadrinhos: é só com ele que todas essas questões encontrarão um terreno ainda mais fértil para serem discutidas, fazendo com que o campo cresça cada vez mais.

Nesse sentido, segundo Vergueiro (2009), quase ao mesmo tempo em que passaram a ser reconhecidas como a "Nona Arte", as histórias em quadrinhos passaram também a ser chamadas de "arte sequencial". Entretanto, para o autor esta seria uma denominação insatisfatória para o campo, visto que esta terminologia pode se referir a outros tipos de produção que não só as histórias em quadrinhos. Por isso, Vergueiro (2009) prefere o termo “Arte Gráfica Sequencial”. Essa definição, acreditamos, não significa exatamente dizer o que é ou o que não é, ou o que pode ou não pode ser considerado história em quadrinhos, e sim uma maneira de definir um espaço de produção que possa levantar esse debate entre obras de uma forma de arte específica, desconsiderando, num primeiro momento, qualquer coisa que não faça parte desse espectro.

A questão agora é observar e analisar os trabalhos quadrinísticos a partir de seus próprios termos, comparando-os com seus próprios pares, parte de seu próprio espaço e com suas próprias características, padrões e critérios, sua estética e sua conformação única, ao contrário de confrontá-los e estudá-los a partir de qualquer outra forma de produção cultural. Mais além, falar que existe um campo de produção cultural específico das histórias em quadrinhos e que ele é legítimo e culturalmente valorizado significa não precisar, no futuro, ficar justificando a escolha dos quadrinhos não só como diversão, mas também como objeto de estudo. Pensarmos neles como um campo consolidado, um campo que produz coisas boas e ruins, como qualquer outro, é pensálos também como um espaço de debate legítimo, e não apenas uma "fantasia" de fãs 
apaixonados. Pensar as histórias em quadrinhos como um campo é deixar o "processo" de lado e transformar o "culturalmente legítimo" em realidade.

Contudo, é sempre preciso - e até de fundamental importância -, ressaltar que não são só esses quadrinhos que transcenderam as limitações do meio que precisam ser considerados nesse processo. Os quadrinhos avaliados como mais populares e baratos, continuam sendo publicados e consumidos em grandes quantidades, influindo na cultura, na língua e costumes de seu grande número de leitores, moldando seus gostos e inclinações. Portanto, afirma Luis Gasca (1977), da mesma forma em que se exaltam os achados estéticos de obras consideradas clássicas para as histórias em quadrinhos, também é de vital importância, "imprescindível" (GASCA, 1977, p. 10) para a nova visão dada para essa cultura, não se ater apenas a esses clássicos e analisar e dar vazão a estes "humildes" e populares personagens que não possuíam, e talvez nem passem a possuir, o caráter de transcendência.

No final das contas, "estamos, sim, vivendo uma grande época para os quadrinhos" (VERGUEIRO, 2009, p. 38). Para Vergueiro (2009), mesmo que a indústria dos quadrinhos continue massificada e massificante - assim como qualquer outra indústria, seja o cinema, a televisão, etc -, talvez essa seja uma época de grandes possibilidades para o meio. As obras que permitem o avanço da linguagem não estão mais engessadas no espaço do quadrinho alternativo; elas alçaram voo e chegaram até o mainstream, reelaborando e aprimorando os gêneros mais tradicionais dos quadrinhos. Não há como negar, então, a grande variedade de material disponível: dos trabalhos mais originais e inovadores até os mais tradicionais; das histórias de super-heróis e de ficção científica, passando pela autobiografia, pelos registros jornalísticos, ensaios, conteúdo erótico, romances, entre muitos outros.

Depois de todo esse processo, artistas, leitores e críticos vêm desenvolvendo uma maior confiança na capacidade dos quadrinhos como um produto culturalmente legítimo e de real valor por expressarem uma ampla gama de ideias e emoções. Por sua presença e onipresença no meio social desde o início do século $\mathrm{XX}$, os quadrinhos contribuíram para modelar a imaginação da sociedade da qual fazem parte e, como um produto voltado para o consumo de massa, também satisfazem os gostos e desejos populares, o que inclui, é claro, as necessidades comerciais. Se o reconhecimento dos quadrinhos como forma de expressão cultural valorizada pelo público em geral passou 
muito tempo em um estágio inicial, sem nenhum aprofundamento, as coisas mudaram nas últimas décadas.

Por isso, o otimismo em relação à legitimação do campo é válido e, diríamos mais, uma realidade. Mesmo que levemos em consideração que ainda existem instâncias culturais que não os reconhecem como produtos de grande valor, outras tantas abrem suas portas aos quadrinhos e reconhecem seu valor e importância no espectro cultural mundial. Se atingir o status de um grande produto cultural parece significar levantar e dizer algo interessante, então os quadrinhos já chegaram lá; afinal, algo interessante a dizer é o que não falta às histórias em quadrinhos. 


\section{REFERÊNCIAS}

ABELL, Catharine. Comics and genre. In: MESKIN, Aaron; COOK, Roy T. (Org.) The art of comics: a philosophical approach. West Sussex: Blackwell Publishing Ltd, 2012.

ADORNO, Theodor W. A indústria cultural. In: COHN, Gabriel (Org.) Comunicação e indústria cultural: leituras de análise dos meios de comunicação na sociedade contemporânea e das manifestações de massa nessa sociedade. São Paulo: Companhia Editora Nacional e Editora da USP, 1971a.

Televisão, consciência e indústria cultural In: COHN, Gabriel (Org.) Comunicação e indústria cultural: leituras de análise dos meios de comunicação na sociedade contemporânea e das manifestações de massa nessa sociedade. São Paulo: Companhia Editora Nacional e Editora da USP, $1971 b$.

ADORNO, Theodor W.; HORKHEIMER, Max. A indústria cultural: o esclarecimento como mistificação das massas. In: Dialética do esclarecimento: fragmentos filosóficos. Rio de Janeiro: Zahar, 1985.

B. David. Epiléptico - volume 1. Tradução de Idalina Lopes. São Paulo: Conrad Editora do Brasil, 2007.

BAHIA, Marcio. A legitimação cultural dos quadrinhos e o Programa Nacional Biblioteca da Escola: uma história inacabada. Revista Educação, Porto Alegre: v. 35, n.3, p. 340-351, set./dez. 2012. Disponível em: $<$ http://revistaseletronicas.pucrs.br/ojs/index.php/faced/article/view/11765>. Acesso em: 17 ago. 2016.

BAKHTIN, Mikhail. Os gêneros do discurso. In: Estética da criação verbal. Tradução feita do francês por Maria Emsantina Galvão G. Pereira. São Paulo: Martins Fontes, 1997.

BARBIERI, Daniele. Los lenguages del cómic. Barcelona/Buenos Aires/México: Paidós, 1998.

BEATY, Bart. Comics versus art. Toronto/Buffalo/London: University of Toronto Press Incorporated, 2012.

Mass culture in the twentieth century. In: BEATY, Bart. Fredric Wertham and the critique of mass culture. Jackson: University Press of Mississippi, 2005 .

BEATY, Bart H; WEINER, Stephen. Introduction. In: BEATY, Bart H e WEINER, Stephen (Ed). Critical survey of graphic novels: independents and underground classics. Massachusetts/New Jersey: Salem Press, 2012.

BELTING, Kevin. Sex, drugs, and comic books: sex, sexuality, and the underground comix industry of the 1960s. History. v. 469, 2012. Disponível em: <http://www.academia.edu/6178083/Sex_Drugs_and_Comic_Books_Sexuality_and_th e_Rise_of_the_Independent_Comix_Industry. > Acesso em: 08 mai. 2016. 
BENJAMIN, Walter. A obra de arte na era de sua reprodutibilidade técnica. In: Magia e técnica, arte e política: ensaios sobre a literatura e história da cultura. Tradução de Sérgio Paulo Rouanet. São Paulo: Brasiliense, 2012 (Obras Escolhidas v.1).

BETTS, Raymond F. Introduction. In: A history of popular culture: more of everything, faster, and brighter. New York/London: Routledge, 2004.

BLUMER, Herbert. A massa, o público e a opinião pública. In: COHN, Gabriel (org.) Comunicação e indústria cultural: leituras de análise dos meios de comunicação na sociedade contemporânea e das manifestações de massa nessa sociedade. São Paulo: Companhia Editora Nacional e Editora da USP, 1971.

BOFF, Ediliane de Oliveira. Traços de uma novela gráfica (resenha). Revista 9a Arte. São Paulo: v. 1, n² 2, p. 93-99, $2^{\circ}$ semestre/2012.

BONGCO, Mila. Reading comics: language, culture, and the concept of the superhero in comic books. New York: Garland Publishing Inc., 2000.

BOURDIEU, Pierre. A distinção: crítica social do julgamento. Tradução de Daniela Kern e Guilherme J. F. Teixeira. São Paulo: Edusp; Porto Alegre: Zouk, 2007.

O ponto de vista do autor. Algumas propriedades gerais dos campos de produção cultural. In: BOURDIEU, Pierre. As regras da arte: gênese e estrutura do campo literário. Tradução de Maria Lucia Machado. São Paulo: Companhia das Letras, 1992.

BRANDT, Jenn. Art Spiegelman's In the Shadow of no Towers and the art of graphic autofiction. Journal of Graphic Novels and Comics, V. 5, $\mathrm{n}^{\circ} 1$, p. 70-78, 2014. Disponível em: $<$ http://www.tandfonline.com/doi/abs/10.1080/21504857.2013.842180?journalCode=rc om20>. Acesso em: 11 ago. 2015.

BREED, Warren. Comunicação de massa e integração sociocultural. In: COHN, Gabriel (Org.) Comunicação e indústria cultural: leituras de análise dos meios de comunicação na sociedade contemporânea e das manifestações de massa nessa sociedade. São Paulo: Companhia Editora Nacional e Editora da USP, 1971.

BRODBECK, Arthur J.; WHITE, David M. Como ler Li'l Abner inteligentemente. In: ROSENBERG, Bernard; WHITE, David Manning (org.) Cultura de massa: as artes populares nos Estados Unidos. Tradução de Octavio Mendes Cajado. São Paulo: Editora Cultrix, 1957.

BUNCHE, Steve. Underground comix and the transformation of the american comic Book. PW Comics Week, May 26, 2009. Disponível em: <http://www.publishersweekly.com/pw/by-topic/new-titles/adultannouncements/article/9677-underground-comix-and-the-transformation-of-theamerican-comic-book.html>. Acesso em: 09 set. 2016.

BURNS, Charles. Black hole: o fim. Tradução de Daniel Pellizzari. São Paulo: Conrad Editora do Brasil, 2008.

CAGNIN, Antonio Luiz. Os quadrinhos: um estudo abrangente da arte sequencial: linguagem e semiótica. São Paulo: Criativa, 2014. 
CARROLL, Lewis. Alice no país das maravilhas; Através do espelho e o que ela encontrou por lá. Ilustrações originais de John Tenniel. Tradução de Maria Luiza X. de A. Borges. Rio de Janeiro: Zahar, 2009.

CARVALHO, André Campos de. Apresentação. In: CAGNIN, Antonio Luiz. Os quadrinhos: um estudo abrangente da arte sequencial: linguagem e semiótica. São Paulo: Criativa, 2014.

CARVALHO, Beatriz Sequeira de. Entre ratos, gatos, porcos e alguns cachorros: a antropomorfia dos personagens de Maus. Anais das 3as Jornadas Internacionais de Histórias em Quadrinhos. São Paulo: ECA/USP, 2015. http://www2.eca.usp.br/anais2ajornada/anais3asjornadas/artigos.php?artigo=artigo_010 620151226392.pdf> Acesso em: 10 jan. 2017.

A “Art” de Spiegelman: as histórias em quadrinhos como gênero literário e a estética mausiana. Monografia. Departamento de Antropologia da Faculdade de Ciências Sociais da Pontifícia Universidade Católica de São Paulo, 2011.

CARVALHO, André Pereira de. O campo dos quadrinhos no Brasil sob a ótica bourdieusiana. Anais das 2as Jornadas Internacionais de Histórias em Quadrinhos. São Paulo: $\quad$ ECA/USP, $2013 . \quad$ Disponível em: $<$ http://www2.eca.usp.br/anais2ajornada/anais2asjornadas/anais/3\%20\%20ARTIGO\%20-\%20ANDRE\%20PEREIRA\%20DE\%20CARVALHO\%20$\% 20 \mathrm{HQ} \% 20 \mathrm{E} \% 20 \mathrm{SOCIEDADE} . p d f>$ Acesso em: 23 out. 2016.

CAU, Mario; GORDON, Rob; KURCIS, Marina. Terapia - volume 2, 2017. Disponível em: < http://petisco.org/terapia/> Acesso em 06. Abr. 2017.

CIRNE, Moacy. A explosão criativa dos quadrinhos. Petrópolis: Editora Vozes Limitada, 1970.

- Quadrinhos, memória e realidade textual. Anais do XXVII Congresso Brasileiro de Ciências da Comunicação - Intercom. Porto Alegre: agosto/ 2004. Disponível em: <http://ltc-ead.nutes.ufrj.br/constructore/objetos/obj3469.pdf> Acesso em: 06 maio 2016.

Quadrinhos, sedução e paixão. Petrópolis: Vozes, 2000.

CHUTE, Hillary; JAGODA, Patrick (Ed.). Special issue: comics \& media. Chicago: University of Chicago, Critical Inquiry, n 40, spring/2014.

COHN, Neil. Comics, Linguistics, and visual language: the past and future of a field. In: BRAMLETT, Frank (Org.). Linguistics and the study of comics. Basingstoke/New York: Palgrave Macmillan, 2012.

CRUMB, Robert. Mr. Natural in Death Valley. Zap Comix, San Francisco, \#0, $7^{\text {a }}$ edição p. 12-16, 1971 ?

DOHERTY, Brian. Comics tragedy: is the superhero invulnerable. In: SCHWARTZ, Ben. The best american comics criticism. Seattle: Fantagraphics Books, 2010.

DUNCAN, Randy; SMITH, Mathew J. The power of comics: history, form and culture. New York: Bloomsbury, 2009. 
EAGLETON, Terry. A ideia de cultura. Tradução de Sandra Castello Branco. 2. Ed. São Paulo: Editora Unesp, 2011.

ECO, Umberto. Apocalípticos e integrados. São Paulo: Perspectiva, 2008.

EISNER, Will. La narración gráfica. Barcelona: Norma Editorial, 2009.

Quadrinhos e arte sequencial: princípios e práticas do lendário cartunista. Tradução de Luís Carlos Borges e Alexandre Boide. São Paulo: Martins Fontes, 2010.

ESCOSTEGUY. Ana Carolina D. Uma introdução aos Estudos Culturais. Revista FAMECOS, Porto Alegre: PUCRS, $\mathrm{n}^{\circ}$ 9, dezembro de 1998. Disponível em: <revistaseletronicas.pucrs.br/ojs/index.php/revistafamecos/article/view/3014/2292> Acesso em: 21 fev. 2016.

ESTREN, Mark James. A History of Underground Comics: 20th Anniversary Edition. Oakland: Ronin Publishing, 2012.

FIEDLER, Leslie A. O meio contra as duas pontas. In: ROSENBERG, Bernard; WHITE, David Manning (org.) Cultura de massa: as artes populares nos Estados Unidos. Tradução de Octavio Mendes Cajado. São Paulo: Editora Cultrix, 1957.

GASCA, Luis. Prefácio. In: MOYA, Álvaro de. Shazam! São Paulo: Editora Perspectiva, 1977.

GIBSON, Mel. British girls' comics, readers and memories. In: DUNCAN, Randy e SMITH, Mathew J. Critical approaches to comics - Theories and Methods. New York/London: Routledge, 2012.

GOMES, Marcelo Bolshaw. Teoria narrativa e arte sequencial: metodologia de análise para histórias em quadrinhos. Revista Imaginário, Paraíba: GPHQ, junho de 2015. Disponível em: http://marcadefantasia.com/revistas/imaginario/imaginario-0110/imaginario-08/imaginario-08.pdf.

GORDON, Ian. Making Comics respectable: how Maus helped redefine a medium. In: WILLIAMS, Paul; LYONS, James (Org.). The rise of American comic artist: creators and contexts. Jackson: University Press of Mississippi, 2010.

GRAVETT, Paul. Graphic Novels: Can you hear the trucks? In: SCHWARTZ, Ben. The best american comics criticism. Seattle: Fantagraphics Books, 2010.

Graphic novels: everything you need to know. New York/London: Harper Collins Publishers, 2005.

GREEN, Justin. Binky Brown meets the holy Virgin Mary. San Francisco: Last Gasp Eco Funnies, 1972.

GROENSTEEN, Thierry. O sistema dos quadrinhos. Tradução de Érico Assis. Nova Iguaçu, RJ: Marsupial Editora, 2015.

HATFIELD, Charles. Alternative comics: an emerging literature. Jackson: University Press of Mississippi, 2005. 
HEER, Jeet; WORCESTER, Kent. Introduction. In: HEER, Jeet e WORCESTER, Kent (Org.). Arguing comics: literary masters on a popular medium. Jackson: University Press of Mississippi, 2004.

HELLER, Agnes. Sobre os Preconceitos. In: O cotidiano e a história. Tradução de Carlos Nelson Coutinho e Leandro Konder. $7^{\text {a }}$ Edição. São Paulo: Editora Paz e Terra, 2004.

HOGGART, Richard. As utilizações da cultura: aspectos da vida da classe trabalhadora, com especiais referências a publicações e divertimentos. Lisboa: Editorial Presença, 1973a.

As utilizações da cultura: $2^{\circ}$ volume: aspectos da vida da classe trabalhadora. Lisboa: Editorial Presença, 1973b.

HUYSSEN, Adreas. Of mice and mimesis: reading Spiegelman with Adorno. New German Critique, nº81, Dialectic of Enlightenment, 2000. Disponível em: <http://www.jstor.org/stable/488546>. Acesso em: 14 mar. 2017.

KELLNER, Douglas. A cultura da mídia - estudos culturais: identidade e política entre o moderno e o pós moderno. Tradução de Ivone Castilho Benedetti. Bauru: EDUSC, 2001.

KELLY, Mike. Art Spiegelman and his circle: New York City Comix and the Downtown Scene. International Journal of Comic Art. V. 10, $\mathrm{n}^{\circ} 1$, p. 313-339, Spring/2008.

KITCHEN, Denis. Foreword. In: SKINN, Dez. Comix: the underground revolution. New York: Thunder's Mouth Press. 2004.

KLAPPPER, Joseph T. Os efeitos da comunicação de massa. In: COHN, Gabriel (org.) Comunicação e indústria cultural: leituras de análise dos meios de comunicação na sociedade contemporânea e das manifestações de massa nessa sociedade. São Paulo: Companhia Editora Nacional e Editora da USP, 1971.

LAZARSFELD, Paul F.; MERTON, Robert K. Comunicação de massa, gosto popular e ação social organizada. In: COHN, Gabriel (Org.) Comunicação e indústria cultural: leituras de análise dos meios de comunicação na sociedade contemporânea e das manifestações de massa nessa sociedade. São Paulo: Companhia Editora Nacional e Editora da USP, 1971.

LOMAN, Andrew. "Thats mouse's shadow": the canonization of Spiegelman's Maus. In: WILLIAMS, Paul; LYONS, James (Org.). The rise of American comic artist: creators and contexts. Jackson: University Press of Mississippi, 2010.

LONGHI, Jon. Preface: Beyond the Bizarre. In: ESTREN, Mark James. A history of underground comics: 20th Anniversary Edition. Oakland: Ronin Publishing, 2012.

LOWENTHAL, Leo. Perspectivas históricas da cultura popular. In: COHN, Gabriel (Org.). Comunicação e indústria cultural: leituras de análise dos meios de comunicação na sociedade contemporânea e das manifestações de massa nessa sociedade. São Paulo: Companhia Editora Nacional e Editora da USP, 1971. 
LUYTEN, Sonia M. Bibe. O que é história em quadrinhos. São Paulo: Brasiliense, 1987.

LYONS, James; WILLIAMS, Paul. Introduction: in the year 3794. In: WILLIAMS, Paul; LYONS, James (Org). The rise of American comic artist: creators and contexts. Jackson: University Press of Mississippi, 2010.

MACDONALD, Dwight. Uma teoria da cultura de massa. In: ROSENBERG, Bernard; WHITE, David Manning (org.) Cultura de massa: as artes populares nos Estados Unidos. Tradução de Octavio Mendes Cajado. São Paulo: Editora Cultrix, 1957.

MARTÍN-BARBERO, Jesús. Dos meios à mediações: comunicação, cultura e hegemonia. Tradução de Ronald Polito e Sérgio Alcides. 7. Ed. Rio de Janeiro: Editora UFRJ, 2015.

MARTINS, Ana Luiza. A palavra re[vista]. In Revistas em Revista. São Paulo: Edusp, 2001.

MATTELART, Armand e NEVEU, Érik. Introdução aos estudos culturais. Tradução de Marcos Marcionilo. São Paulo: Parábola Editorial, 2004.

MAZZUCCHELli, David. Asterios Polip. Tradução de Daniel Pellizzari. São Paulo: Cia. das Letras, 2011.

MCCLOUD, Scott. Desvendando os quadrinhos. São Paulo: M. books do Brasil Editora Ltda. 2005.

MCLUHAN, Marshall. A imagem, o som e a fúria. In: ROSENBERG, Bernard; WHITE, David Manning (Org.) Cultura de massa: as artes populares nos Estados Unidos. Tradução de Octavio Mendes Cajado. São Paulo: Editora Cultrix, 1957.

MESKIN, Aaron; COOK, Roy T. The art and philosophy of comics: an introduction. In: MESKIN, Aaron; COOK, Roy T. (Org.) The art of comics: a Philosophical Approach. West Sussex: Blackwell Publishing Ltd, 2012.

MOORE, Alan; GIBBONS, Dave. Watchmen. California: DC Comics, 2004.

MORAES, Dênis de. Apresentação: o crítico no fulgor da maturidade. In: CIRNE, Moacy. Quadrinhos, sedução e paixão. Petrópolis: Vozes, 2000.

MORIN, Edgar. Cultura de massas no século XX: espírito do tempo I: neurose. Tradução de Maura Ribeiro Sardinha. 10. Ed. Rio de Janeiro: Forense Universitária, 2011.

Cultura de massas no século XX: o espírito do tempo II: necrose. Com a colaboração de Orene Nahoum. Tradução de Agenor Soares Santos. Rio de Janeiro: Forense Universitária, 1986.

MOYA, Álvaro de. Shazam! São Paulo: Editora Perspectiva, 1977.

MUNSON, Kim. How the french kickstarted the acceptance of comics as an art form in the US: the books and exhibitions of Maurice Horn. International Journal of Comic Art , Fall, 2016. In press Disponível em: <http://www.academia.edu/26994403/How_the_French_Kickstarted_the_Acceptance_o 
f_Comics_as_an_Art_Form_in_the_US_the_Books_and_Exhibitions_of_Maurice_Hor n> Acesso em: 14 jul. 2016.

NYE, Russel. The unembarrassed muse: the popular arts in america. New York: The Dial Press, 1982.

ORTEGA Y GASSET, José. A rebelião das massas. Tradução de Herrera Filho. Brasília: Ruriak Ink, 2013.

ORVELL, Miles. Krazy Kat, Maus, and the contemporary fiction cartoon. American Literary History, Vol. 4, No.1, 1992. Disponível em: <http://www.jstor.org/stable/489940>. Acesso em: 14 mar. 2015.

PEREIRA, Elaine Aparecida Teixeira. O conceito de campo de Bourdieu: possibilidade de análise para pesquisas em história da educação brasileira. Revista Linhas, Florianópolis: v.16, n. 32, p. 337-356, set./dez. 2015.

PETERSEN, Robert S. Introduction. In: Comics, manga, and graphic novels: a history of graphic narratives. Santa Barbara/Denver/Oxford: Praeger, 2011.

PONTES, Suely Aires. Mauschwitz: deslocamentos imaginários. Revista Imaginário (USP), v. 14, p. 27-41, 2007.

RAMOS, Paulo. A leitura dos quadrinhos São Paulo: Contexto, 2009a.

Histórias em quadrinhos: gênero ou hipergênero? Grupo de Estudos Linguísticos, São Paulo: n. 38, v. 03, p, 355-367, set/dez 2009b Disponível em: <http://www.gel.org.br/estudoslinguisticos/volumes/38/EL_V38N3_28.pdf> Acesso em: 31 jan. 2016.

Tiras, gênero e hipergênero: como os três conceitos se processam nas histórias em quadrinhos. Anais do VI Simpósio Internacional de Gêneros Textuais. Natal: Universidade Federal Rio Grande do Norte, 2011. Disponível em: $<$ http://www.cchla.ufrn.br/visiget/pgs/pt/anais/Artigos/Paulo\%20Ramos\%20(UNIFESP ).pdf>. Acesso em: 31 jan. 2016.

RAMOS, Paulo; FIGUEIRA, Diego. Graphic novel, narrativa gráfica ou romance gráfico? Terminologias distintas para um mesmo rótulo. Anais da II Jornada de Estudos Sobre Romance Gráfico. Brasília: Grupo de Estudos em Literatura Brasileira Contemporânea, 2011.

RILEY JR., John W.; RILEY, Matilde W. A comunicação de massa e o sistema social. In: COHN, Gabriel (Org.) Comunicação e indústria cultural: leituras de análise dos meios de comunicação na sociedade contemporânea e das manifestações de massa nessa sociedade. São Paulo: Companhia Editora Nacional e Editora da USP, 1971.

ROSENBERG, Bernard. A cultura de massa nos Estados Unidos. In: ROSENBERG, Bernard; WHITE, David Manning (Org.) Cultura de Massa: as artes populares nos Estados Unidos. Tradução de Octavio Mendes Cajado. São Paulo: Editora Cultrix, 1957.

SCHWARTZ, Ben. Introduction. In: SCHWARTZ, Ben. The best American comics criticism. Seattle: Fantagraphics Books, 2010. 
SHELTON, Gilbert. The collected adventures of the fabulous furry freak brother. San Francisco: Rip Off Press, 1971.

SJÅSTAD, Øystein. Comics: this bitter art. In: CORTSEN, Rikke Platz; LA COUR, Erin; MAGNUSSEN, Anne (Org.) Comics and power: representing and questioning cultures, subjects and communities. Newcastle: Cambridge Scholars Publishing, 2015.

SKINN, Dez. Comix: the underground revolution. New York: Thunder's Mouth Press. 2004.

SPIEGELMAN, Art; GRIFFITH, Bill (Ed). Arcade, the comics revue, San Francisco,

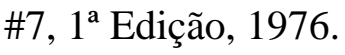

SPIEGELMAN, Art. Breakdowns: Retrato de um Artista quando jovem. Tradução de Vanessa Barbara. São Paulo: Quadrinhos na Cia., 2009.

Maus: a história de um sobrevivente. Tradução de Antonio de Macedo Soares. São Paulo: Companhia das Letras, 2005.

York: Pantheon, 1986.

Maus: a survivor"s tale vol, 1: my father bleeds history. New

Maus: a survivor"s tale vol. 2: and here my troubles began. New

York: Pantheon, 1991.

What the \%\$\#! happened to comics? In: CHUTE, Hillary e JAGODA, Patrick (Ed.). Special issue: comics \& media. Chicago: University of Chicago, Critical Inquiry, no 40, p. 20-35, spring/2014.

THOMPSON, Craig. Habib. Tradução de Érico Assis. São Paulo: Quadrinhos na Cia., 2012.

THOMPSON, John B. Ideologia e cultura moderna: teoria social crítica na era dos meios de comunicação de massa. Petrópolis: Vozes, 1995.

TODOROV, Tzvetan. A análise estrutural da narrativa. In: As estruturas narrativas. São Paulo: Perspectiva, 2003.

TOFFLER, Alvin. Future shock. New York: Bantam Book, 1971.

VERGUEIRO, Waldomiro. A atualidade das histórias em quadrinhos no Brasil: a busca de um novo público. História, imagem e narrativas, V. 5, p. 1-20, 2007.

As histórias em quadrinhos no limiar de novos tempos: em busca de sua legitimação como produto artístico e intelectualmente valorizado. Visualidades Revista do Programa de Mestrado em Cultura Visual - FAV/UFG. Goiânia: v.7, n. 1, p. 14-41, 2009.2 Disponível em: <http://www.revistas.ufg.br/VISUAL/article/view/18118/10807> Acesso em: 14 nov. 2014.

Os quadrinhos: a valorização (e desvendamento) da linguagem dos quadrinhos. In: CAGNIN, Antonio Luiz. Os quadrinhos: um estudo abrangente da arte sequencial: linguagem e semiótica. São Paulo: Criativa, 2014. 
VIANA, Nildo. A intelectualidade como classe social. Revista Eletrônica Espaço Acadêmico, Maringá/PR: v. 65, p.10-16, 2006. Disponível em: $<$ http://informecritica.blogspot.com.br/2011/03/intelectualidade-como-classesocial.html>. Acesso em: 07 jul. 2016.

O que os quadrinhos dizem? As histórias em quadrinhos são objetos de leitura de um amplo público e como todo fenômeno social, passaram a ser objeto de estudo da Sociologia e de outras ciências. (Reportagem). s/d. Disponível em: <http://sociologiacienciaevida.uol.com.br/ESSO/Edicoes/18/artigo98209-1.asp.> Acesso em: 07 jul. 2016.

WARSHOW, Robert. Paul, as histórias de horror em quadrinhos e o Dr. Wertham. In: ROSENBERG, Bernard; WHITE, David Manning (Org.) Cultura de massa: as artes populares nos Estados Unidos. Tradução de Octavio Mendes Cajado. São Paulo: Editora Cultrix, 1957.

WARTENBERG, Thomas E. Wordy Pictures: Theorizing the relationship between image and text in comics. In: MESKIN, Aaron; COOK, Roy T. (Org.) The art of comics: a philosophical approach. West Sussex: Blackwell Publishing Ltd, 2012.

WHITE, David Manning. A cultura de massa nos Estados Unidos: um outro ponto de vista. In: ROSENBERG, Bernard; WHITE, David Manning (Org.) Cultura de massa: as artes populares nos Estados Unidos. Tradução de Octavio Mendes Cajado. São Paulo: Editora Cultrix, 1957.

WILliAMS, Raymond. Cultura. Tradução de Lólio Lourenço Oliveira. São Paulo: Editora Paz e Terra, 1992.

Cultura e sociedade: de Coleridge a Orwell. Tradução de Vera Joscelyne. Petrópolis: Vozes, 2011.

Marxismo e literatura. Tradução de Waltersin Dutra. Rio de Janeiro: Zahara Editores, 1979.

Palabras clave. Un vocabulario de la cultura y la sociedade. Tradução de Horacio Pons. Buenos Aires: Nueva Visión, 2003.

WILSON, S. Clay. The checkered demon. Zap Comix, San Francisco, \#9, $1^{\text {a }}$ impressão p. 3, set. 1978.

WITKIN, Robert W. Adorno on popular culture. New York/London: Routledge, 2003.

WOLK, Douglas. Reading comics: how graphic novels works and what they mean. Boston: Da Capo Press, 2007. 